\title{
Zróżnicowanie dostępności transportowej miast w województwie lódzkim
}


盗 


\section{Szymon Wiśniewski}

Zróżnicowanie

dostępności

transportowej miast

w województwie lódzkim 
Szymon Wiśniewski - Uniwersytet Łódzki, Wydział Nauk Geograficznych, Katedra

Zagospodarowania Środowiska i Polityki Przestrzennej, 90-142 Łódź, ul Kopcińskiego 31

RECENZENT

Tomasz Komornicki

REDAKTOR WYDAWNICTWA UŁ

Iwona Gos

SKŁAD KOMPUTEROWY

$A G E N T$ PR

\section{PROJEKT OKŁADKI}

Stämpfli Polska Sp. z o.o.

Zdjęcie na okładce: Cshutterstock.com

(C) Copyright by Uniwersytet Łódzki, Łódź 2015

Wydane przez Wydawnictwo Uniwersytetu Łódzkiego

Wydanie I. W.06735.14.0.D

ISBN 978-83-7969-521-8 (wersja papierowa)

ISBN 978-83-7969-522-5 (wersja elektroniczna)

Wydawnictwo Uniwersytetu Łódzkiego

90-131 Łódź, ul. Lindleya 8

www.wydawnictwo.uni.lodz.pl

e-mail: ksiegarnia@uni.lodz.pl

tel. (42) 66558 63, faks (42) 6655862 


\section{SPIS TREŚCI}

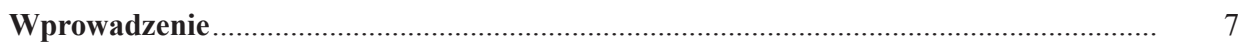

1. Istota i uwarunkowania dostępności transportowej ...................................................... 17

1.1. Wymiary i charakterystyka dostępności ..................................................................... 17

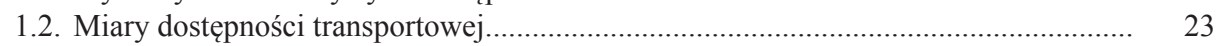

1.3. Uwarunkowania dostępności transportowej ................................................................ 32

1.4. Dostępność transportowa w świetle dokumentów strategicznych ............................... 40

2. Dostępność transportowa miast $w$ świetle infrastruktury transportowej .................... 51

2.1. Infrastruktura drogowa i kolejowa regionu łódzkiego w krajowej sieci transportowej.... 51

2.2. Sieć osadnicza a system transportowy regionu łódzkiego............................................... 62

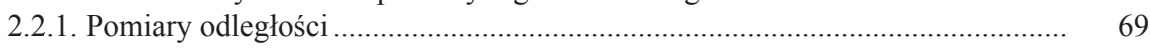

2.2.2. Dostępność potencjałowa ................................................................................. 81

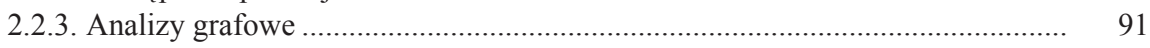

2.3. Dostępność a wyposażenie infrastrukturalne ........................................................... 104

3. Dostępność transportowa miast w świetle transportu zbiorowego …........................... 117

3.1. Organizacja transportu zbiorowego w województwie łódzkim.................................. 117

3.2. Powiązania miast województwa łódzkiego w systemie transportu zbiorowego ............ 124

3.3. Funkcjonowanie transportu zbiorowego a poziom dostępności................................... 145

4. Dostępność transportowa miast w świetle transportu indywidualnego …................... 165

4.1. Dostępność transportowa w ujęciu teoretycznym ....................................................... 165

4.2. Dostępność transportowa w ujęciu modelowym ........................................................ 178

5. Dostępność transportowa miast - ujęcie syntetyczne …............................................. 189

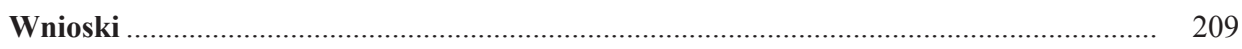

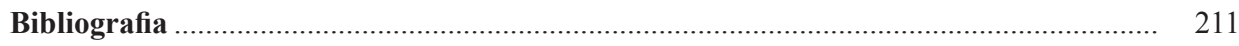

Spis rycin

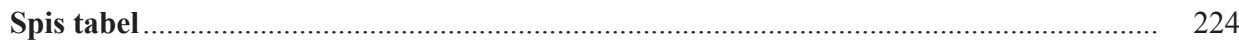





\section{WPROWADZENIE}

Problematyka opracowania koncentruje się na zagadnieniu dostępności transportowej miast w województwie łódzkim. W sposób najbardziej ogólny dostępność transportową należy postrzegać jako miarę poziomu trudności osiągania danych miejsc za pośrednictwem środków transportu. Miejscami, dla których możliwe jest określenie dostępności, mogą być miasta, ich poszczególne części, a także mniejsze jednostki osadnicze. $Z$ drugiej strony, analizy mogą się skupiać na większych jednostkach, takich jak gminy, powiaty czy regiony, ujętych samodzielnie lub w zgrupowaniach. Dostępność transportowa jako jeden z najważniejszych czynników systemu gospodarczego znacząco wpływa na rozwój społeczno-gospodarczy miast i regionów. Sprzyjając powstawaniu nowych miejsc pracy, ośrodków handlowych czy intensyfikując promocję ośrodków turystycznych, stymuluje ona wzrost gospodarczy, jednocześnie likwiduje bariery wynikające z peryferyjności poszczególnych miejsc czy obszarów.

Opracowanie ma charakter statyczny i przedstawia stan na koniec maja 2014 r. Przestrzenny zakres analizy ograniczony jest do granicy województwa łódzkiego. Jedynie w części pracy poświęconej relacjom pomiędzy siecią osadniczą i transportową województwa w ujęciu grafowym oraz wyposażeniu infrastrukturalnym analizy wykraczają poza jego granicę administracyjną, co ma na celu urealnienie wyników badań. Traktowanie systemu transportowego województwa jako samoistnie funkcjonującej w oderwaniu od szerszego tła przestrzennego struktury mogłoby bowiem stanowić do pewnego stopnia zafałszowanie rzeczywistości. Głównym celem opracowania jest zbadanie zróżnicowania dostępności transportowej miast województwa łódzkiego, którego realizacja wymagała osiągnięcia trzech celów dodatkowych:

- określenia dostępności potencjalnej poprzez inwentaryzację i analizę wyposażenia w infrastrukturę transportową - drogową, kolejową i tramwajową województwa łódzkiego. Założenie to zostało zrealizowane poprzez wielopoziomową analizę materiałów źródłowych udostępnionych przez zarządców infrastruktury w połączeniu z niezbędnymi badaniami terenowymi;

- zbadania dostępności w zakresie transportu zbiorowego dzięki analizie funkcjonowania przewoźników realizujących połączenia pomiędzy miastami województwa łódzkiego. W celu osiągnięcia tak sformułowanego zadania odwoła- 
no się do wszechstronnej analizy danych o kursowaniu poszczególnych środków transportu, pozyskanych od samych przewoźników, serwisów internetowych oraz tabliczek przystankowych, w wyniku samodzielnych badań terenowych autora;

- przeanalizowania dostępności w zakresie samochodowego transportu indywidualnego w oparciu o określenie czasu i kosztu dojazdów do miast województwa łódzkiego, które wykonano w odniesieniu do analiz teoretycznych, modelowych oraz danych o ruchu przekazywanych w czasie rzeczywistym.

Punktem wyjścia postępowania badawczego było sprecyzowanie pojęcia „dostępność transportowa" przez wskazanie jego wymiarów i charakterystyki, wszechstronnych uwarunkowań oraz ugruntowania w dokumentach o charakterze strategicznym. W dalszej kolejności chodziło o pokazanie sposobów jej pomiaru. Przy tej okazji istotne wydaje się przedstawienie zróżnicowania nowych podejść do określania poziomu dostępności. Rozważania na ten temat zostały zawarte we wprowadzeniu oraz w pierwszym rozdziale merytorycznym. Zastosowane ujęcie opisowe jest traktowane dwojako: jako cel sam w sobie dla ujęcia teoretycznego oraz jako punkt wyjścia do dalszych analiz o charakterze empirycznym.

Treść kolejnych czterech rozdziałów została podporządkowana realizacji głównego celu opracowania, a mianowicie wykazania zróżnicowania dostępności transportowej miast województwa łódzkiego. Punktem wyjścia do tych analiz było określenie specyfiki infrastruktury transportowej województwa łódzkiego na tle krajowej sieci transportowej, poprzez charakterystykę porównawczą poszczególnych jej składowych, przy użyciu przede wszystkim metod statystycznych oraz kartograficznych. W dalszej części rozdziału drugiego skupiono się na relacji pomiędzy siecią osadniczą a systemem transportowym regionu łódzkiego, poprzez szczegółową inwentaryzację elementów infrastruktury drogowej, kolejowej i tramwajowej. W konsekwencji pozwoliło to na określenie różnie ujmowanych odległości pomiędzy wszystkimi 44 miastami województwa. Dalszą analizę wykonano w oparciu o metodę potencjałową, podejście grafowe oraz obliczenie wskaźnika odnoszącego wyposażenie infrastrukturalne wokół miast do liczby ich mieszkańców i powierzchni.

Zawartość kolejnego rozdziału wynika z celu opracowania odnoszącego się do transportu zbiorowego. Na wstępie przedstawiono zasady jego organizacji w województwie łódzkim, uwzględniające działających na regionalnym rynku przewoźników i zakres przestrzenny ich funkcjonowania. Ukazane zostały powiązania pomiędzy miastami regionu w systemie transportu zbiorowego oraz jego wpływ na poziom dostępności poprzez analizę częstotliwości połączeń, czasu i kosztów koniecznych do przejazdu na danej trasie. Badanie odnosi się również do poziomu substytucyjności ofert poszczególnych przewoźników. W celu realizacji powyższych zagadnień posłużono się m.in. wskaźnikiem obciążenia komunikacyjnego. Wizualizacji wyników badań dokonano poprzez metodę izolinii, konstruując izochrony, ekwidystanty czy izodapany. 
W kolejnym rozdziale podjęto tematykę dostępności transportowej w świetle samochodowego transportu indywidualnego. Objęła ona badanie teoretycznego czasu przejazdu pomiędzy miastami zgodnie z przepisami ruchu drogowego. A ponadto określono czas i koszt przejazdu, ale obliczony zgodnie z modelem uwzględniającym m.in. natężenie ruchu, gęstość zaludnienia oraz ukształtowanie powierzchni. Uzupełnieniem tej części rozprawy jest autorski projekt badawczy, którego celem było określenie rzeczywistej dostępności transportowej na podstawie danych dostarczanych przez Google Maps Traffic, obrazujących ruch drogowy w czasie rzeczywistym.

W piątym rozdziale opracowania przedstawiono wcześniej uzyskane wyniki badań $\mathrm{w}$ formie syntetycznej. Pozwoliło to określić dostępność transportową każdego z miast regionu łódzkiego we wszystkich trzech wymiarach (potencjalnym, zbiorowym, indywidualnym). W celu określenia stosownych klasyfikacji i typologii wykorzystano standaryzację danych. Zawarte w nim zestawienia zbiorcze wraz z wynikami cząstkowymi dały podstawę do sformułowania wniosków w ostatniej części opracowania.

Rozpoczynając rozważania poświęcone dostępności transportowej, należy najpierw wskazać miejsce tak określonego przedmiotu badań w zakresie nauk geograficznych. Zgodnie z przyjętym w geografii rozróżnieniem, transport rozumiany jako przemieszczanie osób i ładunków wraz z łącznością (przekazywanie informacji na odległość) stanowią komunikację. Wyraźne rozgraniczenie tych dwóch pojęć nabrało sensu w związku z dynamicznym rozwojem i wagą przywiązywaną do badań transportu oraz łączności. Wynikiem potrzeby implementacji do badań transportu ujęć i metodologii charakterystycznej dla nauk geograficznych jest współwystępowanie dwóch działów geografii ekonomicznej w postaci geografii transportu oraz geografii łączności. Dlatego też stosowanie podejścia tradycyjnego w postaci terminu „dostępność komunikacyjna” należy postrzegać jako ogólne określenie dostępności transportowej oraz dostępności łącznościowej. W przypadku sprecyzowania, które z pojęć jest przedmiotem badania, ewentualne niejasności terminologiczne są bezpodstawne. Możliwe jest pojmowanie dostępności transportowej w formie bardzo ogólnej, jako możliwość dotarcia do określonego miejsca z miejsca stanowiącego punkt początkowy podróży, najczęściej dzięki wykorzystaniu środków transportu. Potrzeby transportowe, niezależnie od ich specyfiki, są zaspokajane bezpośrednio przez piesze dojścia do celu lub pośrednio przez dotarcie do punktu transportowego i podróż za pośrednictwem różnych form przewozu. Efektywne funkcjonowanie tychże systemów transportowych wymaga odpowiedniej infrastruktury technicznej oraz organizacji przekładającej się m.in. na liczbę połączeń bezpośrednich i konieczność przesiadek podczas podróży transportem zbiorowym (Warakomska 1992).

W celu uniknięcia niejasności trzeba określić podstawowe terminy stosowane w geografii transportu, takie jak droga, linia czy szlak. Drogę należy ujmować jako wydzielony pas terenu przystosowany do ruchu pojazdów, a zatem 
odpowiednio urządzony. Wyróżnić można różnego rodzaju drogi: kołowe, wodne czy kolejowe. Określenie linii transportowej ma charakter funkcjonalny, tym samym łączy się nierozerwalnie $\mathrm{z}$ ruchem, przewozem lub przesyłaniem konkretnym środkiem technicznym (koleją, samochodem, statkiem, samolotem) na określonym odcinku, przy wykorzystaniu przyjętej drogi. Natomiast zespół linii łączących dane punkty, węzły lub miejscowości stanowi szlak transportowy. Miejsca, w których wykonywany jest załadunek, przeładunek lub wyładunek towarów, a także rozpoczyna się lub kończy podróż pasażera, określone są jako punkty transportowe. Szczególną odmianę punktów transportowych stanowią węzły łączące co najmniej trzy drogi lub linie transportowe. Zbiór dróg i linii oraz punktów i węzłów tworzy sieć transportową. W rzeczywistości funkcjonuje wiele sieci, np. kolejowe, drogowe, tramwajowe, które pełnią wobec siebie często komplementarne lub substytucyjne role. Sieć jest z kolei jednym z elementów systemu transportowego. Jako najbardziej złożona struktura zawiera wszelkie urządzenia techniczne, sprawy ekonomiczne i organizację we wzajemnym powiązaniu, które tworzą i zarządzają całym procesem transportowym, działającym zazwyczaj w oparciu o kilka gałęzi transportu. Geografia szczególną uwagę przykłada do procesu przemieszczania $\mathrm{w}$ przestrzeni i w związku $\mathrm{z}$ tym należy zdefiniować takie terminy, jak przepływ, przewóz i przebieg. Pod pojęciem przepływu należy rozumieć wielkość dóbr lub osób przemieszczanych z miejsca początku podróży do miejsca ich przyjęcia, przy czym przepływ nie oznacza samego procesu transportowania i nie podaje drogi, po której się odbywa. Za termin bliskoznaczny do przepływu często uznaje się przewóz. Natomiast wymagają one stosownego rozróżnienia, ponieważ przewóz pasażerów lub ładunków odbywa się po konkretnej i wiadomej drodze transportu (Potrykowski, Taylor 1982).

W opracowaniu przeanalizowano system transportowy województwa łódzkiego, skupiając się na sieci drogowej, kolejowej oraz tramwajowej. Wszelkie analizy wykonywano przy założeniu transportu pasażerskiego. Na etapie badania funkcjonowania transportu zbiorowego przyjęto, że pasażerem jest osoba dorosła, której nie przysługują jakiekolwiek zniżki przy zakupie biletu. Natomiast przewozy mogą odbywać się autobusem, busem, pociągiem lub tramwajem. Transport indywidualny, będący przedmiotem analizy w rozdziale czwartym, realizowany jest przez samochód osobowy, tj. pojazd przeznaczony do przewozu nie więcej niż 10 osób wraz z kierowcą, a jego dopuszczalna masa całkowita nie przekracza 3,5 t (Ilustrowany stownik statystyk transportu, b.r.w.).

Dostępność transportowa jest często poruszanym tematem badawczym, szczególnie na polu geografii. Literatura poświęcona temu zagadnieniu jest bogata zarówno w odniesieniu do pozycji polskich, jak i zagranicznych. Wartościowe opracowania powstawały w połowie ubiegłego stulecia, ale również obecnie ich nie brakuje. Tak szerokie spektrum materiałów daje znaczne możliwości badawcze. Po pierwsze, umożliwia konfrontacje reprezentowanych w nich podejść i rozwiązań. Po drugie zaś, pozwala na przegląd i uwzględnienie zagadnień 
podstawowych, koniecznych do prowadzenia bardziej zaawansowanych analiz oraz dotarcie do najnowszych badań bazujących na aktualnych założeniach metodologicznych, wykonywanych na danych obrazujących bieżącą sytuację społeczno-gospodarczą. Wyraźna intensyfikacja badań dotyczących dostępności transportowej jest związana $\mathrm{z}$ analizami prowadzonymi przez Instytut Geografii i Przestrzennego Zagospodarowania PAN w Warszawie. Dominującym profilem aktualnych rozważań poświęconych dostępności transportowej są zagadnienia modelowania ruchu drogowego, zmiany poziomu dostępności w wyniku realizacji inwestycji infrastrukturalnych $\mathrm{w}$ zakresie transportu, powiązania pomiędzy dostępnością a spójnością terytorialną i badania nad dostępnością potencjałową. Wyraźnie mocniej eksponowane są powyższe zagadnienia w odniesieniu do dużych jednostek osadniczych (m.in. miast wojewódzkich), gmin czy regionów. Szeroki zakres przestrzenny szczególnie uwidacznia się w literaturze światowej, gdzie dostępność transportowa jest rozpatrywana na poziomie międzynarodowym i globalnym. Znacznie rzadziej prezentowane są elementy badań dotyczące miast średnich i małych, kluczowych dla badań dostępności na poziomie regionalnym czy lokalnym.

W ramach analizowanej w niniejszej pracy literatury wyróżnić można cztery grupy tematyczne. Do pierwszej z nich zaliczyć należy opracowania poświęcone szeroko pojętej tematyce geografii transportu. W tym zakresie odwołano się m.in. do Berezowskiego (1975), Gęsiarza (1982) oraz Lijewskiego (1986), których pozycje w ogólny sposób wprowadzają w tematykę geografii transportu. Zagadnienia podstawowe poszerzono dzięki pracy Potrykowskiego i Taylora (1982), która dodatkowo stanowiła bogate źródło rozważań metodologicznych. Uzupełnieniem były publikacje Taylora (1980, 2007), przybliżające zagadnienia społecznej geografii transportu i funkcjonowanie transportu kolejowego. Sięgnięto również do pozycji skupiających się na poszczególnych sferach geografii transportu, a ujętych w kolejnych częściach opracowania. Informacje na temat infrastruktury transportu zaczerpnięto m.in. z publikacji Grzywacza (1982). Zagadnienia związane z transportem zbiorowym wyjaśniono m.in. dzięki tekstowi Kolarskiego (1976), natomiast kwestie dotyczące inżynierii ruchu drogowego na podstawie pracy Gacy i in. (2008). W celu uszczegółowienia charakterystyki sieci transportowych województwa łódzkiego oraz ich rozwoju sięgnięto m.in. do pozycji Liszewskiego (1965), Kuleszy i Kotera (1998), Schielego (1998), Sobczyńskiego (2005) czy Suliborskiego i in. (2009). Dzięki informacjom zawartym w wymienionych pozycjach możliwe było zarysowanie treści wprowadzających we wstępie opracowania oraz części zagadnień ogólnych stanowiących podstawę do dalszych rozważań i badań autora. Prace te miały również charakter porządkujący w odniesieniu do toku postępowania badawczego czy stosowanej w dysertacji nomenklatury.

Drugą grupę stanowią pozycje bezpośrednio traktujące o dostępności transportowej. W ramach tej grupy literatury sięgnięto m.in. do pozycji Domańskiego 
(1980), wprowadzającej w tematykę dostępności, również w ujęciu transportowym. Zagadnienia wstępne w zakresie analiz dostępności transportowej zaczerpnięto również od Warakomskiej (1992). Wykorzystano ponadto badania Sobczyk (1985), skupiające się na dostępności w układach osadniczych. Pozycja ta pozwoliła również na wdrożenie do niniejszej pracy pewnych rozwiązań metodologicznych. Kwestie pomiarów dostępności oparto na tekście Baradaran i Ramjerdi (2001). Bardzo cenne dla realizacji niniejszej pracy były publikacje Rosika (2008, 2012). Założenia metodologiczne w nich zawarte ujęto w zakresie analizy porównawczej województw Polski pod względem wyposażenia w infrastrukturę transportową oraz modelu prędkości ruchu pojazdów osobowych. Równie bogatym źródłem informacji dotyczących ujęć dostępności transportowej, jak i metod stosowanych dla jej mierzenia była pozycja Komornickiego i in. (2009) na temat relacji między dostępnością przestrzenną a polityką transportową. Uzupełnienie stanowiły pozycje Majewskiego i Beima (2008) oraz Gadzińskiego (2010), odnoszące analizy dostępności do funkcjonującego na danym obszarze transportu zbiorowego. Ogólnie rzecz ujmując, literatura bezpośrednio odwołująca się do tematyki dostępności transportowej umożliwiła określenie wymiarów i charakterystyki dostępności, a przez to wskazanie miejsca realizowanych analiz w całej systematyce badań nad nią. Pozwoliła również na przegląd wypracowanych dotychczas metod pomiaru. Publikacje należące do obydwu grup literatury miały charakter porządkujący i pozwoliły na ujednolicenie stosowanego w dalszej części opracowania nazewnictwa odnoszącego się do dostępności. Dalsze rozważania dotyczące pojęcia dostępności transportowej znalazły się w podrozdziale 1.1.

W pracy odwołano się również do literatury poświęconej relacjom pomiędzy transportem i jego infrastrukturą a środowiskiem przyrodniczym. Sięgnięto m.in. do badań Leszczyckiego (1971) i Tylutkiego (1975). Publikacje Jakubowskiego (1976), Kręgielewskiego (1979) i Mazura $(1985,1998)$ poszerzyły zakres analizowanych współzależności pomiędzy środowiskiem przyrodniczym a transportem. Pozycje te pozwoliły na kompleksową charakterystykę uwarunkowań poziomu dostępności transportowej, związanych z poszczególnymi komponentami środowiska przyrodniczego, będących uzupełnieniem dla czynników antropogenicznych.

Ostatnią grupę stanowią pozycje przedstawiające zagadnienia metodologiczne. Wykorzystano je zarówno jako podstawę do zastosowanych w pracy analiz wyposażenia infrastrukturalnego, funkcjonowania transportu zbiorowego i indywidualnego, jak i do uzupełnienia przeglądu metod pomiaru dostępności. Oparto go m.in. na badaniach, które opublikowali Handy i Niemeir (1997), Geurs i Ritsema von Eck (2001) czy Sierpiński (2010). W zakresie metod grafowych odwołano się m.in. do publikacji Kansky’ego (1963), Zagożdżona (1970, 1971, 1977), Taylor (1974, 1975), Ratajczaka (1977) czy Kudłacza (1981), którego badania łączyły analizy grafowe $\mathrm{z}$ metodami grawitacji. Kompleksowe omówienie metod potencjału i grawitacji wraz z przykładowymi zastosowaniami umożliwiło ich adapta- 
cję na potrzeby badań realizowanych w niniejszym opracowaniu. Sięgnięto w tym zakresie m.in. do badań Chojnickiego (1966), Portykowskiego (1980) i Śleszyńskiego (2009b). Również analizy związane z samochodowym transportem indywidualnym poparto wynikami rozważań o charakterze metodologicznym, zawartymi m.in. w publikacji Brzezińskiego (1999), poświęconej metodom analiz ruchu. W podobnym nurcie badawczym jest publikacja Rosika i Śleszyńskiego (2009), dająca podstawy do rozważań nad budową modelu ruchu pojazdów. Do grupy tej zaliczyć należy również pewne pozycje zawierające się w pierwszych dwóch wymienionych grupach. Łączą one bowiem podstawy teoretyczne z ich ilustracją w postaci przykładowych analiz wykonanych zgodnie z postulowana metodą. W grupie tej znalazły się również pozycje prezentujące wyniki badań w sposób syntetyczny.

Ze względu na problematykę podejmowaną w niniejszym opracowaniu konieczne było sięgnięcie do licznych materiałów źródłowych. Wykorzystano m.in. dokumenty o charakterze strategicznym, odnoszące się wprost do tematyki transportu, jak np.: Polityka transportowa państwa 2006-2025 (2005), Strategia rozwoju transportu do 2020 r. z perspektywa do 2030 r. (2011), Master plan dla transportu kolejowego w Polsce do 2030 r. (2008), ewentualnie mówiące o nim pośrednio poprzez zapisy dotyczące rozwoju społeczno-gospodarczego czy planowania przestrzennego na poziomie regionalnym, krajowym czy międzynarodowym, takie jak: Polityka spójności 2014-2020 (2011), Koncepcja przestrzennego zagospodarowania kraju 2030 (2012), Strategia rozwoju kraju w perspektywie średnio i dtugookresowej, Krajowa strategia rozwoju regionalnego 2010-2020 (2010); Aktualizacja planu zagospodarowania przestrzennego województwa łódzkiego (2010) czy Strategia rozwoju województwa tódzkiego 2020 (2013). Analiza treści dokumentów stanowiła bogate źródło informacji na temat sposobu postrzegania, roli i rangi przypisanej dostępności transportowej. Opracowania tego typu umożliwiły pozyskanie danych o charakterze diagnostycznym w celu określenia aktualnego i przyszłego poziomu dostępności województwa łódzkiego.

Uzupełnieniem treści dokumentów o charakterze strategicznym były wykorzystane w niniejszym opracowaniu akty prawne o zasięgu krajowym i europejskim. Odwołano się m.in. do zapisów Decyzji Parlamentu Europejskiego, chcąc przedstawić położenie województwa łódzkiego w transeuropejskiej sieci transportowej. Wiele wnoszącym materiałem były także zapisy zawarte w ustawach o publicznym transporcie zbiorowym, o ruchu drogowym, o drogach publicznych oraz transporcie kolejowym. Pozwoliły na urealnienie prowadzonych badań do obowiązujących przepisów. Dostarczyły, jak w przypadku kodeksu drogowego, danych do badań samochodowego transportu indywidualnego. Uwzględniono również treści aktów wykonawczych w postaci rozporządzeń dotyczących m.in. stawek opłat za przejazdy autostradą, warunków technicznych, jakim powinny odpowiadać budowle kolejowe i ich usytuowanie, czy też drogi publiczne i ich usytuowanie. Ich zapisy stanowiły często niezbędne uzupełnienie wspomnianych 
dokumentów, ułatwiając zrozumienie zawartych w nich komentarzy. Analiza zapisów prawa pozwoliła na uporządkowanie informacji i zapobiegła przedstawieniu ich w oderwaniu od obowiązujących zasad. Treść przywołanych ustaw i rozporządzeń stanowiła również podstawę do określenia założeń metodologicznych, jak chociażby w przypadku ustalenia maksymalnych dozwolonych prędkości poruszania się pojazdów.

Niezwykle cennym źródłem informacji, a zarazem podstawą do realizacji i wizualizacji wykorzystywanych metod badawczych były materiały kartograficzne. Dzięki współpracy z zarządcami infrastruktury transportowej możliwe było pozyskanie materiałów niezbędnych do wykonania koniecznych inwentaryzacji. Udostępnione mapy, prezentujące przebieg poszczególnych elementów infrastruktury $\mathrm{w}$ wersji wektorowej, poza znacznym ułatwieniem i przyśpieszeniem analiz, dały możliwość pracy na danych zawartych w powiązanych z treścią mapy bazach. Pozyskane mapy rastrowe poddano digitalizacji lub też włączono do dalszej analizy, jak w przypadku autorskiego programu bazującego na danych o ruchu pojazdów w postaci zrzutów ekranu. Odwołano się również do technik teledetekcyjnych, w postaci zdjęć lotniczych i ortofotomapy, które stanowiły uzupełnienie prowadzonej inwentaryzacji.

Równie bogatym źródłem informacji były, pozyskane na potrzeby niniejszego opracowania, bazy danych. Zostały one zaczerpnięte wprost od zarządców infrastruktury transportowej (m.in. od GDDKiA oddział w Łodzi, w postaci wyciągu z Banku Danych Drogowych, Zarządu Dróg Wojewódzkich w Łodzi, Zarządu Dróg i Transportu w Łodzi), przedsiębiorców transportu zbiorowego, instytucji samorządowych (m.in. od Urzędu Marszałkowskiego Województwa Łódzkiego) czy urzędów centralnych (m.in. od Głównego Urzędu Statystycznego), w postaci kwerend $\mathrm{z}$ istniejących baz lub przygotowywanych specjalnie na potrzeby badania. W ten sposób możliwe było uzyskanie informacji m.in. w zakresie kilometraży dróg i linii kolejowych wraz z opisem technicznym, warstw tematycznych dotyczących zabudowy czy statystyk umożliwiających analizy porównawcze regionalnego zainwestowania infrastrukturalnego.

Bardzo istotnym źródłem informacji były również serwisy internetowe poszczególnych instytucji oraz przedsiębiorstw, których działalność związana jest z przedmiotem niniejszej pracy. Poza tym, że w wielu przypadkach są źródłem dostępu do wskazanych wcześniej baz danych, stanowią źródło informacji samo w sobie, umożliwiając kontakt z instytucją (jak w przypadku GDDKiA oraz PKP Polskich Linii Kolejowych S.A.) czy przedsiębiorstwem. Istotnym źródłem informacji były również internetowe serwisy branżowe poświęcone m.in. rynkowi motoryzacyjnemu, jak np. http://www.samar.pl/, czy przedstawiające w sposób zbiorczy oferty przewozowe, tak jak http://autobusowyrozkladjazdy.pl/, http://www. koleje.wask.pl/czy http://www.rozklad-pkp.pl/. Niezwykle wartościowa ze względu na przedmiot realizowanej pracy okazała się strona internetowa poświęcona dostępności transportowej, prowadzona przez Instytut Geografii i Przestrzennego 
Zagospodarowania PAN. Uwzględnienie jej zasobów pozwoliło na określenie najbardziej aktualnych trendów we współczesnych badaniach nad dostępnością transportową i dotarcie do najnowszych materiałów temu poświęconych.

W opracowaniu wykorzystano również dane pozyskane z projektów i ekspertyz poświęconych tematyce dostępności, transportu czy infrastruktury transportowej. Bardzo wartościowym materiałem z tego zakresu były opracowania autorstwa Komornickiego i in. $(2008,2011)$, dotyczące odpowiednio metodologii obliczania wskaźnika międzygałęziowej dostępności transportowej i dostępności transportowej we wschodniej Polsce. Pozwoliły bowiem na poszerzenie rozważań metodologicznych. Sięgnięto również do prac Rosika i in. $(2011,2012)$ odnoszących się do badania dostępności transportowej gmin i monitoringu ich spójności terytorialnej. Zawarte w nich rozważania pozwoliły na rozszerzenie badań nad podejściem potencjałowym i wprowadzenie analizy dostępności kosztowej. Również praca Guzika (2011) stanowiła ważne źródło informacji, ponieważ skupiono się w niej na analizie dostępności transportowej w odniesieniu do miast. W zakresie transportu zbiorowego odwołano się do opracowań Bartosiewicza i Marszała (2011) oraz Paczkowskiego i Budlera (2012), dzięki którym możliwe było uzupełnienie treści dotyczących funkcjonowania tego typu transportu w granicach województwa łódzkiego. Wartość tychże projektów i ekspertyz przejawia się przede wszystkim $w$ aktualności zawartych $w$ nich danych i innowacyjności stosowanych metod badawczych. Te pierwsze stanowić mogą dane diagnostyczne do prowadzonych badań, natomiast prezentacja metod umożliwia poszerzenie przeglądu zawartego w pracy, a przede wszystkim prowadzenie badań autorskich zgodnie z funkcjonującym obecnie podejściem. 



\section{ISTOTA I UWARUNKOWANIA DOSTĘPNOŚCI TRANSPORTOWEJ}

\subsection{Wymiary i charakterystyka dostępności}

Jednym z podstawowych pojęć w zakresie nauk społecznych, a w szczególności w geografii społeczno-ekonomicznej, gospodarce przestrzennej i ekonomii, jest dostępność. Badania nad nią, prowadzone przez specjalistów z zakresu powyższych nauk, mają długą tradycję.

Chcąc w sposób najbardziej ogólny scharakteryzować pojęcie dostępności, należy wskazać, że jest to zdolność do powstania relacji pomiędzy więcej niż jednym elementem zbioru (Komornicki i in. 2009). Przy takim założeniu możliwe jest sformułowanie podstawowych cech charakterystycznych dla sprecyzowania przedmiotu dostępności. Po pierwsze, jest to występowanie w przestrzeni społeczno-gospodarczej przynajmniej dwóch elementów będących odpowiednio miejscem źródłowym i docelowym dostępności, które są względem siebie osiągalne (jednostronnie lub bilateralnie). Druga cecha charakterystyczna odnosi się do środka komunikacji, pełniącego rolę nośnika powiązań łączących wspomniane wcześniej punkty przestrzeni i przełamującego jej opór w postaci czynników społeczno-ekonomicznych, polityczno-administracyjnych czy przyrodniczych. Tak postrzegana dostępność implikuje występowanie dwóch komplementarnych względem siebie pojęć dostępności - w ujęciu transportowym i przestrzennym (ibid.), które zostaną wyjaśnione w dalszej części pracy.

W rozumieniu Karlqvista (1975) dostępność jest odwołaniem do podstawowej cechy zachowań ludzi, którzy dążą do maksymalizacji kontaktów, wykazując w związku z tym możliwie niską aktywność, rozumianą jako wysiłek konieczny do ich podtrzymania. Ograniczenie wysiłku w postaci ponoszenia kosztów poruszania się jest utożsamione $\mathrm{z}$ dostępnością również w literaturze ekonomicznej (Vickerman 1974). Hansen (1959) definiuje dostępność jako potencjał zaistnienia interakcji w sensie społeczno-ekonomicznym (Handy, Niemeier 1997). Dalsza analiza literatury przedmiotu pozwala rozumieć pojęcie dostępności jako łatwość zachodzenia tychże interakcji w przestrzeni. Ze względu na temat rozprawy szczególnie istotna wydaje się definicja Bruinsma i Rietvelda (1998) ujmująca to 
pojęcie jako atrakcyjność konkretnego węzła sieci, uwzględniająca masy pozostałych zlokalizowanych w niej węzłów oraz koszty przemieszczenia się do nich za pomocą tejże sieci. Ten sam punkt widzenia dostępności prezentuje Ingram (1971), który przedstawia ją jako nieodłączną cechę miejsca, powiązaną ze sposobem pokonywania oporu przestrzeni w postaci odległości lub czasu. Inni autorzy (Dalvi, Martin 1976) uznają dostępność jako „łatwość dotarcia do dowolnej aktywności, z dowolnego miejsca, z wykorzystaniem określonego systemu transportowego". Wskazywano również, że dostępność charakteryzuje lokalizację, odnosząc ją do szans, działalności i zasobów osiągalnych w innych lokalizacjach. W tym ujęciu lokalizację można ujmować punktowo (miasto), liniowo/pasmowo (korytarz transportowy) oraz powierzchniowo (region). Warakomska (1992) „dzieli" dostępność pod względem obiektu analizy na dostępność obszaru, dostępność sieci transportowej oraz topologiczną dostępność sieci transportowej. Pierwszą z nich określa m.in. gęstość sieci transportowej w danym regionie, drugą - dystans do elementu sieci, zaś dostępność topologiczną scharakteryzować można dzięki metodom grafowym (zostaną szczegółowo omówione w dalszej części pracy). Dostępność jest wyrażeniem powszechnie używanym, natomiast nie wiąże się z tym jego odpowiednie definiowanie, a tym bardziej określenie narzędzi jej pomiaru (Gould 1969).

Dostępności nie należy utożsamiać z ruchliwością, ponieważ zgodnie z Taylorem (1999) ruchliwość to przemieszczanie się, natomiast dostępność to tylko potencjalna możliwość takiego przemieszczania. Komornicki (2009) podkreśla konieczność wyraźnej separacji pojęcia dostępności od przewozów. Dostępność bowiem kształtuje wielkość potoków ruchu, będąc przesłanką dla podróży, a nie jej wynikiem. Dlatego też inwestycje infrastrukturalne w zakresie transportu, powodując podniesienie poziomu dostępności, mogą przyczynić się do wzmożenia ruchu.

Jeszcze większe problemy towarzyszą ustalaniu brzmienia definicji pojęć powiązanych z dostępnością. Konieczne jest bowiem rozróżnienie poza dostępnością transportową jeszcze m.in. dostępności komunikacyjnej, przestrzennej, społecznej, ekonomicznej, fizycznej czy czasowej. Zdecydowanie najbardziej klarowne relacje występują na styku dostępności transportowej i dostępności komunikacyjnej. Tak jak lakonicznie wspomniano we wstępie pracy, na komunikację składa się transport i łączność. Dlatego też należy dostępność komunikacyjną rozumieć dwojako - jako dostępność transportową i dostępność łącznościową (Potrykowski, Taylor 1982). Wyraźnego rozróżnienia wymagają również pojęcia dostępności i osiągalności. Ułatwia to zaproponowana przez Taylora (1999) trójdzielna natura dostępności - przestrzenna, społeczna i ekonomiczna. Dwa ostatnie aspekty, będąc uzależnione od cech każdego indywidualnego użytkownika systemu transportowego, oddziałują bezpośrednio na osiągalność danej destynacji. Tym samym osiągalność danego celu podróży uzależniona jest od zamożności, pozycji społecznej osób korzystających z systemu transportowego, w którym znajduje się dany cel. Dostępność przestrzenna, zasygnalizowana na wstępie, jak sama nazwa 
wskazuje, dotyczy przemieszczania się w przestrzeni, jednakże w tym przypadku posiadane przez użytkownika zasoby finansowe nie mają żadnego znaczenia. Zestawiając ze sobą dostępność komunikacyjną i przestrzenną, należy za Guzikiem (2003) podkreślić nadrzędność tej pierwszej (dotyczy to również dostępności transportowej) nad dostępnością w ujęciu przestrzennym. Guzik w swoich rozważaniach wyraźnie zaznacza, że dostępność komunikacyjna zawiera w sobie wszystkie „stosunki komunikacyjne” mające miejsce na danym obszarze.

Syntetyczne ujęcia dostępności transportowej ukazują ją jako łatwość osiągania danego miejsca ze zbioru innych miejsc dzięki istnieniu sieci i usług transportowych (Accessibilité des territoires et des services. Notions et representation 2008) lub też jako mierzalną wielkość oddalenia przestrzennego między danym miejscem a miejscami, z którymi chce ono być powiązane w zależności od wybranego środka transportu (Cauvin 2005).

Kompleksowa definicja dostępności transportowej stworzona na potrzeby Diagnozy polskiego transportu (2011) odnosi się do istnienia realnych i efektywnych możliwości fizycznego komunikowania się między dowolnymi punktami przestrzeni dla osiągania pożądanych celów. Dany punkt obszaru jest tym dostępniejszy transportowo, im więcej jest innych punktów, do których można dotrzeć zadowalająco szybko, tanio i sprawnie. Przegląd pojmowania zjawiska dostępności każe jednoznacznie uznać, że brak jest uniwersalnej i powszechnie obowiązującej definicji dostępności transportowej (Baradaran, Ramjerdi 2001).

Wielopłaszczyznowy charakter dostępności transportowej oraz stosowanie najczęściej uogólnionych definicji przyczynia się do nieprecyzyjnego i mało komunikatywnego wizerunku tego pojęcia w świadomości społecznej (Diagnoza polskiego transportu 2011).

Do dostępności transportowej przywiązywano dużą wagę od momentu zakończenia drugiej wojny światowej, czego świadectwem jest obszerna literatura przedmiotu z tamtego okresu. Tematyka dostępności poparta rozwiązaniami metodologicznymi w zakresie modeli potencjału i grawitacji była powszechnie wykorzystywana na potrzeby analiz transportowych oraz planistycznych. Szczególnie dynamiczny rozkwit rozważań z zakresu dostępności miał miejsce po publikacjach Isarda, a następnie towarzyszył rozwojowi regional science (Komornicki i in. 2009). Na gruncie europejskim dostępność transportowa znalazła swoje odzwierciedlenie w licznych publikacjach. Szczególnym bodźcem przyśpieszającym rozwój badań w tym zakresie były procesy integracji europejskiej. Namacalnym wynikiem świadomie kreowanej polityki transportowej jest stworzenie i ustawiczny rozwój transeuropejskich sieci transportowych, których głównym celem staje się osiągnięcie najwyższej spójności przestrzennej krajów członkowskich. Abstrahując od dyskusji definicyjnych, można jednoznacznie wskazać, że aby w pełni zrozumieć problematykę dostępności transportowej konieczne jest spojrzenie na wszystkie jej elementy składowe. Dwa fundamentalne człony to komponent transportowy oraz komponent użytkowania terenu (ibid.). Współwy- 
stępowanie obu elementów implikuje wzajemne oddziaływanie pomiędzy polityką transportową a polityką zagospodarowania przestrzennego.

Chcąc przedstawić wielowymiarowość dostępności transportowej, należy powrócić do jej transportowego komponentu. Analiza relacji pomiędzy początkiem podróży a jej celem wymaga rozpatrzenia oporu, który będzie towarzyszył przemieszczaniu się. W licznych badaniach za miarę tego oporu przyjmowano m.in.: odległość fizyczną (linia prosta pomiędzy początkiem a celem podróży), odległość fizyczną rzeczywistą (najkrótsza odległość drogowa), odległość czasową, odległość ekonomiczną (dotyczącą kosztów podróży - zakup paliwa, biletu itd.) oraz wysiłek (wygoda podróży) (ibid.). Poza tymi podstawowymi wymiarami w literaturze pojawia się również odległość wirtualna, będąca długością umownej linii komunikacyjnej prostej i poziomej, na której koszt przewozu ładunku jest identyczny z kosztem transportu po rzeczywistej linii transportowej o zróżnicowanym profilu. Dlatego właśnie długość wirtualna jest większa od długości rzeczywistej. Dzisiaj ujęcie to ma raczej znaczenie historyczne (Warakomska 1992). Komponent transportowy może odnosić się także do odległości funkcjonalnej. Jest to odległość od centrum (różnie ujmowanego w badaniach geograficzno-ekonomicznych) do obszarów peryferyjnych (Miszewska 1988). Potrykowski i Taylor (1982) podają również odległość społeczną wpisującą się w nurt społecznej geografii transportu. Tak rozumiany opór przestrzeni powoduje, że poziom dostępności jest silnie zróżnicowany ze względu na różny nakład czasu lub kosztów związanych z podróżą w odczuciu poszczególnych użytkowników. Uzależniony jest od ich sytuacji materialnej i środka transportu, z którego mogą korzystać. Odległość społeczną można definiować jako: polityczną, socjologiczną lub psychologiczną odmianę wspomnianej już dostępności ekonomicznej. Ponieważ, jak podkreśla Domański (1990), to właśnie czas i koszt decydująco oddziałują na przestrzenne zachowania użytkowników sieci transportowej, a nie odległości fizyczne pomiędzy obiektami. Jeszcze bardziej w kierunku odczuć poszczególnych użytkowników skierowane są rozważania dotyczące odległości mentalnych. Jest to podejście związane ze społeczną geografią transportu i z rozwojem na przełomie lat sześćdziesiątych i siedemdziesiątych ubiegłego wieku, nowego nurtu badań, preferującego skupienie uwagi na człowieku, jego zachowaniu i społecznych uwarunkowaniach ruchliwości. Ludzie mają różne wyobrażenia o dostępności danego obiektu położonego $\mathrm{w}$ miejscu ich stałego zamieszkania lub poza nim, zależnie od liczby odbytych do tego punktu podróży, czasu ich trwania, rodzaju wykorzystywanych środków transportu, stopnia komfortu podróży, kondycji fizycznej itd. Wynikiem rozważań nad wyobrażeniową dostępnością poszczególnych celów podróży może być sporządzenie mapy mentalnej (Taylor 1980).

Według wytycznych zawartych $\mathrm{w}$ pierwszym sprawozdaniu okresowym ESPON z 2002 r., poświęconemu usługom i sieciom transportowym oraz podstawowemu zaopatrzeniu infrastrukturalnego, dla spójności terytorialnej do pełnego określenia dostępności transportowej danego obszaru niezbędne staje się sprecy- 
zowanie takich elementów (rycina 1.1), jak: jednostki odniesienia, czyli wspominane już obszary lub miejsca startu i zakończenia podroży, a także kategorie równości społecznej, czyli poziom dostępu dla ludności.

Konieczny jest oczywiście wybór przedmiotu przemieszczania, tzn. czy transportowani będą ludzie czy też ładunki, oraz funkcji dających możliwość dostępu (sieć infrastruktury transportowej, usługi transportowe). Analiza powinna również określać środki transportu spośród szerokiego spektrum możliwości wyboru, jakie daje dzisiejsza technologia. Przy pomiarze dostępności transportowej wybranego obszaru konieczne jest podanie jej parametrów. Obszerny wybór metod pomiaru pozwala odnosić się m.in. do prędkości czy kosztu. Doprecyzować należy również, czy dostępność będzie rozpatrywana w zakresie wzajemnych relacji pomiędzy dwoma obiektami czy też w sposób sieciowy. Obszar badań determinuje ponadto skalę dostępności, m.in. międzynarodową, krajową do głównych ośrodków miejskich czy też lokalizacji o znaczeniu strategicznym, jak granice czy lotniska, regionalną w zakresie wzajemnych powiązań elementów sieci osadniczej oraz lokalną ukazującą zasięg oddziaływania komunikacji zbiorowej z siedziby władz gminy. ESPON wskazuje również na konieczność sprecyzowania istotności analizowanych powiązań transportowych i czas badania poziomu dostępności - czy będzie ona rozpatrywana w konkretnym zakresie czasowym czy też będzie miała charakter ciągłego monitoringu. Ostatnie dwa elementy to określenie pobudek skłaniających użytkownika do uzyskania dostępu - czynniki ekonomiczne i pozaekonomiczne oraz wskazanie stabilności dostępności (Diagnoza polskiego transportu 2011).

Biorąc pod uwagę ilość i złożoność powyższych elementów, wydaje się niemożliwe stworzenie zwięzłej i zarazem kompleksowej definicji dostępności transportowej.

Pociągnęło to za sobą mnogość tworzenia specyficznych pojęć, takich jak: dostępność czasowa, dostępność gałęziowa, dostępność wielogałęziowa (multimodalna), dostępność transportu publicznego, dostępność do węzłów transportu, dostępność potencjałowa itd.

W Polsce tematyką dostępności transportowej zajmowali się m.in.: Chojnicki (1966), Czyż (2002), Domański (1979, 1980), Guzik (2003), Powęska (1990), Ratajczak (1992, 1999), Sobczyk (1985), Taylor (1979, 1999), Warakomska (1992), Wendt (2000). Liczne badania z tego zakresu prowadzone są w Instytucie Geografii i Przestrzennego Zagospodarowania PAN w Warszawie. Zespół Komornickiego (Śleszyński, Rosik, Pomianowski, Siłka, Stępniak) realizował prace koncepcyjno-teoretyczne, związane z szerszym zastosowaniem problematyki dostępności transportowej w planowaniu i zagospodarowaniu przestrzennym (m.in. Komornicki i in. 2008, 2009; Rosik i in. 2011, 2012). Działania na styku geografii transportu i planowania przestrzennego przyczynily się do utworzenia otwartej grupy badawczej, wyspecjalizowanej w analizach dostępności transportowej z wykorzystaniem modeli numerycznych. Uruchomiano również internetową witrynę badań dostępności transportowej w IGiPZ PAN (www.igipz.pan.pl/accessibility/pl). 


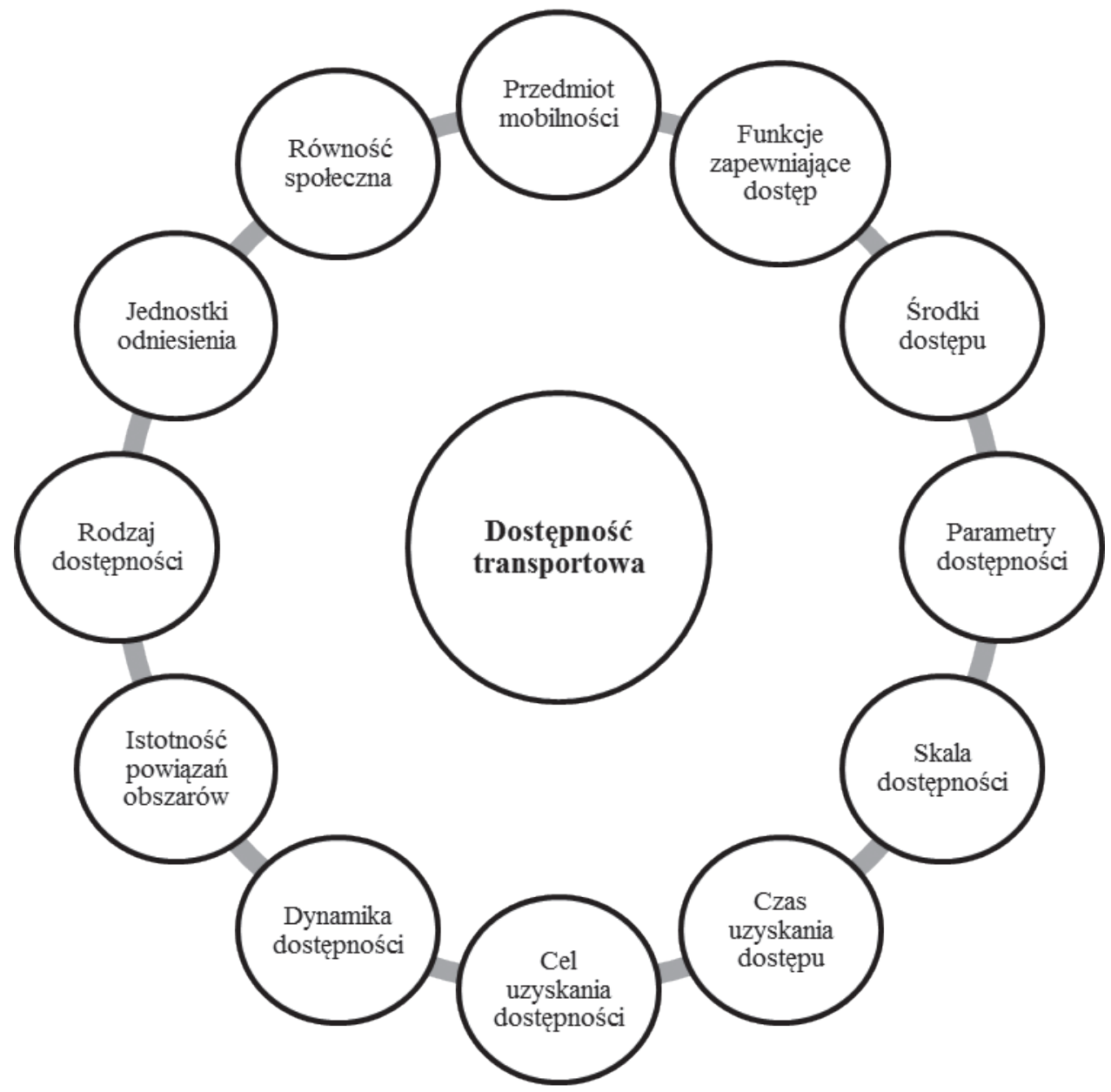

Rycina 1.1. Elementy precyzujące dostępność transportową obszaru Źródło: opracowanie własne na podstawie ESPON (2002)

Badania dostępności transportowej odnaleźć można w analizach wykonywanych m.in. przez Ministerstwo Rozwoju Regionalnego (np. Koncepcja przestrzennego zagospodarowania kraju 2030, 2012), Ministerstwo Transportu, Budownictwa i Gospodarki Morskiej (np. Program budowy dróg krajowych na lata 2011-2015, 2011) oraz władze samorządowe na szczeblu regionalnym (np. Strategia rozwoju województwa tódzkiego 2020, 2013). Podmioty publiczne, jak i prywatne odwołują się do badań dostępności na etapie analiz lokalizacji elementów infrastruktury technicznej i społecznej.

Dostępność transportowa, jakkolwiek definiowana, ma istotny wymiar aplikacyjny, gdyż stanowi element diagnozy problemów w przemieszczaniu się lu- 
dzi i towarów, dając podstawy do prowadzenia właściwej polityki transportowej ukierunkowanej na spójność terytorialną (Rosik 2012). Ponadto uznawana jest za istotny element organizacji przestrzeni znajdujący bezpośrednie odzwierciedlenie w zróżnicowaniu atrakcyjności poszczególnych lokalizacji. Jest ważnym czynnikiem kształtującym m.in. poziomu życia czy atrakcyjność inwestycyjną danego miejsca. Wszystko to jest szczególnie istotne, kiedy rozpatrywana jest dostępność miasta. Jego rozwój wiąże się z potencjalnym oddziaływaniem, wielkością obsługiwanego obszaru, możliwością pozyskiwania pracowników, klientów usług, co z kolei jest bezpośrednio powiązane z poziomem dostępności danej jednostki osadniczej. Jeszcze istotniejszą rolę pełni dostępność transportowa w przypadku całego układu osadniczego na danym obszarze. Tylko zapewnienie wysokiego poziomu sieciowej dostępności transportowej wszystkich elementów układu osadniczego może skutkować spójnością terytorialną regionu (Guzik 2011).

\subsection{Miary dostępności transportowej}

Dla zbadania dostępności transportowej należały dokonać wyboru punktów, dla których będzie ona określana, następnie celów, do których będzie mierzona oraz przyjąć odpowiednie miary dostępności. W literaturze przedmiotu występuje szeroki zasób definicji i metod jej mierzenia. W najogólniejszej formie jest to potwierdzenie występowania połączenia danego źródła i celu lub ustalenie odległości pomiędzy tymi miejscami. Bardziej zaawansowana grupa metod ma natomiast charakter parametrów techniczno-ekonomicznych biorących pod uwagę m.in. odległość, czas, koszt, liczbę ludności, do której można dotrzeć z danego punktu, lokalny lub regionalny rynek pracy, liczebność podmiotów gospodarczych (Janecki, Krawiec 2009).

Wymierna ocena dostępności transportowej obszaru opiera się na spójnym układzie wskaźników charakteryzujących zarówno potencjał infrastruktury liniowej i węzłowej, jak i wskaźników odnoszących się do usług transportowych w wymiarze ilościowym, czasowym i kosztowym (Diagnoza polskiego transportu 2011).

Poszukiwanie metod umożliwiających ocenę oraz prognozowanie przyczyniło się do wyraźnego wzrostu popularności tematyki dostępności w ujęciu użytkowym. Wielowątkowe analizy dostępności były stosowane m.in. na potrzeby określania obszarów deficytowych w zakresie wyposażenia infrastrukturalnego czy też sił oddziaływania ośrodków metropolitalnych (Komornicki i in. 2009).

Dokonując analizy miar dostępności, należy nawiązać do jej podziału na przedstawione już komponenty - transportowy i przestrzenny oraz czasowy i indywidualny. Dostępność transportowa jest determinowana przez sposób zagospodarowania przestrzeni oraz system transportowy. Ponadto użytkownicy sie- 
ci mogą różnić się w ocenie dostępności, w zależności od momentu czasowego podróży (komponent czasowy) oraz indywidualnych cech społeczno-ekonomicznych (komponent indywidualny). Komponent transportowy ukazuje zdolność wykonania podróży między określonymi punktami sieci transportowej. Stały wzrost liczby pojazdów korzystających z sieci drogowo-ulicznej, przy jednoczesnych ograniczeniach możliwości dalszej rozbudowy infrastruktury, staje się przyczyną zatłoczenia miast. W tej sytuacji komponent transportowy może stanowić główne kryterium określenia dostępności transportowej (przez analizę istniejącej infrastruktury). Najczęściej jest wyrażany poprzez czas i prędkość podróży oraz straty czasu wynikające $\mathrm{z}$ występowania znacznego zatłoczenia. $\mathrm{Z}$ uwagi na zmienność ruchu w czasie istotne staje się również badanie komponentu czasowego. Uwzględnia on zarówno wahania dobowe dla poszczególnych dni tygodnia, jak i sezonowe (Sierpiński 2010).

Wśród specjalistów z zakresu ekonomii, planowania przestrzennego i geografii istnieje znaczne zróżnicowanie w zakresie grupowania metod analizy dostępności transportowej. Na podstawie podziału zaproponowanego przez zespół Tomasza Komornickiego (2009) oraz przeglądu innych pozycji literatury przedmiotu, możliwe było sformułowanie przeglądu sposobów badań i pomiarów dostępności transportowej złożonego z sześciu głównych grup metod (rycina 1.2).

Pierwsza z nich to zespół metod pomiaru dostępności transportowej opartych na badaniu wyposażenia infrastrukturalnego. W literaturze określanych również jako wskaźniki proste. Dostępność mierzona za pomocą wskaźników wyposażenia infrastrukturalnego danego obszaru (m.in. jednostki podziału administracyjnego czy ustalonego buforu) odnosi się do jej ilości, jakości i poziomu występującej kongestii. Zliczane są długości poszczególnych dróg, istnienie na danym obszarze badawczym lotniska czy też portu morskiego. Jakość elementów infrastruktury określana jest poprzez prędkość, z jaką możliwe jest poruszanie się po niej, stan techniczny, a w przypadku obiektów obsługujących ruch pasażerski lub towarowy - wydajność w jednostce czasu. Zatłoczenie natomiast można ocenić, badając natężenia ruchu na danym odcinku i zestawiając je z techniczną charakterystyką infrastruktury. Zespół tych metod jest często stosowany w ramach oceny prowadzonej polityki transportowej.

Niewątpliwą zaletą wskaźników opartych na wyposażeniu infrastrukturalnym jest duża dostępność danych wejściowych do analizy oraz stosunkowa łatwość wnioskowania na podstawie danych wyjściowych. Za wadę wskaźników prostych trzeba jednak uznać ograniczenie analizy wyłącznie do granic badanego obszaru. Przewaga kolejnych, bardziej złożonych metod badawczych tkwi w tym, że włączają do analizy dwa wspomniane już wcześniej, fundamentalne komponenty dostępności - transportowy i przestrzenny, natomiast wskaźniki proste pomijają zupełnie użytkowanie przestrzeni. W niniejszym opracowaniu metoda pomiaru wyposażenia infrastrukturalnego została wykorzystana m.in. w postaci wskaźnika średnioważonego, obliczanego dla buforów utworzonych wokół 


\section{Dostępność mierzona wyposażeniem infrastrukturalnym}

- ilość składników infrastruktury

- jakość składników infrastruktury

- poziom kongestii

\section{Dostępność mierzona odleglością}

- dojednego celu podróży - dostępność relatywna

- dostępnośćmierzoną odległością do zbioru celów podróży-dostępność

topologiczna

\section{Dostępność mierzona izochronami - kumulatywna}

- częstotliwość środka transportu

- dostępność czasowa do środka transportu

- dostępność czasowa przemieszczania się środkami transportu

- podróż brutto/netto

- jazda brutto/netto

\section{Dostępność potencjalowa}

-wielkość oddziaływania określonej liczby mas na jedną masę - wskaźnik

potencjału

- wielkość wzajemnego oddziaływania dwóch mas - model grawitacji

\section{Dostępność spersonifikowana}

-dzienne ścieżki życia

- przestrzeń potencjalnych ścieżek

- dostępność dzienna

\section{Dostępność mierzona maksymalizacją użyteczności}

- dostępność indywidualna

- zaspokojenie potrzeby transportowej

Rycina 1.2. Główne zagadnienia ujmowane w metodach pomiaru dostępności transportowej

Źródło: opracowanie własne na podstawie Komornicki i in. (2009), Rosik (2012)

miast. Dzięki niej możliwe było wnioskowanie o potencjalnych możliwościach dotarcia do miasta w ujęciu lokalnym.

Drugą grupą metod określenia dostępności transportowej są pomiary odległości. Wielowymiarowość definiowania dostępności transportowej implikuje również różnorodne podejścia do definiowania odległości. Dlatego też można 
mówić o odległości fizycznej, fizycznej rzeczywistej, czasowej czy ekonomicznej. Przegląd literatury przedmiotu wskazuje na podział tej metody ze względu na liczbę celów podróży. Pierwsza grupa pozwala określić dostępność relatywną, definiowaną jako siła powiązań dwóch miejsc lub punktów w przestrzeni (Ingram 1971). Druga grupa to metody pozwalające określić dostępność topologiczną, czyli mierzoną odległością do wielu celów. Nazwa metody wywodzi się ze zbioru metod grafowych, gdzie oznacza sumę oddaleń z jednego węzła do pozostałych (Taylor 1999). Zestaw stosowanych wskaźników dla tej metody nie różni się od używanych przy ustalaniu dostępności relatywnej, natomiast konieczne jest ich sumowanie lub uśrednianie. Dostępność mierzona odległością jest narzędziem powszechnie używanym na potrzeby ustalenia maksymalnych czasów dojazdu do określonych obiektów zgodnie z wytycznymi polityki transportowej. Wysoką wartością użytkową omawianych wskaźników jest (podobnie jak w przypadku pomiaru wyposażenia infrastrukturalnego) praktycznie nieograniczony dostęp do danych (m.in. atlasy drogowe, aplikacje nawigacyjne, rozkłady jazdy komunikacji zbiorowej) oraz wyniki analizy łatwe do percepcji. W przeciwieństwie jednak do miar wyposażenia infrastrukturalnego, pomiary odległości biorą pod uwagę zarówno komponent transportowy, jak i przestrzenny. Za wadę metod pomiaru długości trzeba niewątpliwie uznać pominięcie kwestii wielkości obiektów docelowych. Duże miasta metropolitalne i małe miasta stanowiące zaplecze dla pobliskich terenów wiejskich są w rozumieniu powyższej metody jednakowo istotne. Ponadto wskaźniki bazujące na pomiarze odległości czasowej nie różnicują atrakcyjności pomiędzy elementami zlokalizowanymi blisko siebie i od siebie oddalonymi. Komornicki i in. (2009) wskazują również na ułomność metody, która ujawnia się przy dużej ilości wyznaczonych celów podróży o równomiernym rozmieszczeniu w przestrzeni. W takiej sytuacji średnie czasy podróży do wszystkich założonych celów wyrównują się. Metoda pomija też całkowicie zróżnicowanie użytkowników sieci transportowej pod względem ich statusu społecznego i ekonomicznego. Metoda ta znalazła liczne zastosowania w niniejszym opracowaniu, określając zarówno dostępności relatywne, jak i topologiczne każdego z 44 miast województwa łódzkiego. Była stosowana jako metoda zasadnicza, ale jej wyniki stanowiły również fundament do pogłębionych analiz.

Pokrewną do metody pomiaru odległości jest kolejna metoda określania dostępności transportowej odnosząca się do wykorzystania izochron, nazywana również dostępnością kumulatywną (Rosik 2012) lub dzienną. Opiera się ona na wyznaczeniu obszarów o takiej samej odległości czasowej. Następnie możliwe jest sprecyzowanie celów podróży, do których da się dotrzeć w określonym czasie, przy poniesionych kosztach podróży lub wysiłku. Czas podróży pomiędzy dwoma punktami w przestrzeni geograficznej zależy od bardzo wielu zmiennych. Wpływać mogą na niego m.in. rodzaj środka transportu, cechy użytkownika sieci czy też warunki przyrodnicze. Dlatego aby możliwe było oszacowanie czasu, badania muszą przyjmować pewien poziom generalizacji, chociażby w postaci za- 
łożenia, że celem użytkownika jest maksymalne skrócenie czasu przemieszczania się pomiędzy początkiem trasy a jej końcem.

W zakresie dostępności w ujęciu czasowym wyróżniono (Komornicki i in. 2009) trzy grupy wskaźników przestrzennej dostępności transportowej. Pierwsza z nich, wydzielona na podstawie częstotliwości środka transportu, obejmuje proste miary, takie jak liczba kursów na danej trasie w ciągu dnia. Druga grupa zawiera miary dostępności czasowej do środka transportu, czyli m.in. izochrony dojścia do przystanku autobusowego czy stacji kolejowej. Ostatnią grupę ustalono, biorąc pod uwagę kryterium dostępności czasowej przemieszczania się środkami transportu, czyli m.in. prędkość jazdy poszczególnymi środkami transportu.

Chcąc ocenić poziom dostępności transportowej na podstawie odległości czasowych $\mathrm{w}$ indywidualnym transporcie samochodowym, konieczne jest doprecyzowanie kategorii czasu. Rozróżnić należy przede wszystkim czas podróży i czas jazdy oraz określić ich wartości brutto i netto. Czas poświęcony na dotarcie do samochodu, przejazd wraz ze wszystkimi przerwami (np. na tankowanie) i dojście do miejsca docelowego określa podróż brutto. Kiedy mierzony jest jedynie sam etap przejazdu (wraz z przerwami), to jest to czas podróży netto. Jazda brutto mówi o czasie potrzebnym na pokonanie odległości pomiędzy początkiem i końcem podróży, jednak bez jakichkolwiek przerw. Ostatnia kategoria (jazda netto) określa czas niezbędny do pokonania trasy, również bez przerw na odpoczynek czy posiłek, ale również bez ograniczeń (zatrzymań) wynikających z organizacji ruchu czy zatłoczenia. Inne określenie czasu jazdy netto to czas przejazdu w ruchu.

Zalety i wady dostępności transportowej mierzonej izochronami są podobne do zalet i wad dostępności mierzonej odległościami. Natomiast dzięki izochronom możliwe jest dokładniejsze wyznaczenie obszaru badań, a zwiększanie liczby izochron umożliwia ujawnienie zróżnicowania w dostępności poszczególnych celów. Izochrony znalazły swoje zastosowanie w częściach opracowania dotyczących funkcjonowania transportu zbiorowego, przedstawiając m.in. jego zasięg w zakresie jednej godziny jazdy, oraz indywidualnego ukazującego np. czas dojazdu do miast województwa łódzkiego w ustalonych interwałach czasowych.

Kolejna grupa metod pozwala określić dostępność potencjałową. Jest ona dość jednoznacznie definiowana w światowym środowisku naukowym, jako pojęcie związane z teorią grawitacji i potencjału. Zgodnie z tym pojęciem, za bardziej dostępne są uznawane regiony o większej masie (np. liczbie ludności) i dobrze skomunikowane z pozostałymi, leżące w środku obszaru (Diagnoza polskiego transportu 2011).

Wykorzystywane są w tym zakresie wskaźniki potencjału lub modele grawitacji określające możliwość zaistnienia relacji pomiędzy miejscem początkowym podróży a wszystkimi jej celami. Termin „dostępność potencjałowa” pochodzi od słowa „potencjał”, a nie od słowa „potencjalny”, czyli możliwy, prawdopodobny. Ta niejednoznaczność w wielu przypadkach skutkowała błędnym rozumieniem i sto- 
sowaniem obydwu pojęć. Aby finalnie wyjaśnić wszelkie nieporozumienia, zespół badawczy IGiPZ PAN zdecydował o zmianie polskiego brzmienia nazwy metody z dotychczasowej ,potencjalnej” na „potencjałową”, którą należy odczytywać jako dostępność mierzoną za pomocą modelu potencjału (Rosik 2012). W niniejszym opracowaniu określenie „potencjalny” wykorzystano w części syntetycznej, gdzie mówi ona o możliwościach w zakresie dostępności transportowej poszczególnych miast województwa łódzkiego, wyliczonych na podstawie m.in. wyposażenia infrastrukturalnego, liczenia odległości, metody grafowej czy potencjałowej.

Dostępność obliczana za pomocą metod potencjałowych uwzględnia zarówno komponent transportowy, jak i użytkowania terenu. Dostępność potencjałowa szacowana jest bowiem na podstawie wskaźników zakładających wzrost atrakcyjności punktu/obszaru docelowego wraz ze wzrostem jego masy - komponent użytkowania terenu, natomiast spadek atrakcyjności towarzyszy przyrostowi odległości (fizycznej, czasowej, ekonomicznej) dzielącej go od punktu/obszaru początkowego - komponent transportowy. Sumę ilorazów mas celów i odległości (czasów) je dzielących po raz pierwszy na określenie dostępności wykorzystał w 1959 r. Hansen. Za atrakcyjność celu podróży przyjąć można m.in. liczbę ludności, dochód, liczbę podmiotów gospodarczych, liczbę szkół, kin czy pełnione funkcje administracyjne. Jest to oczywiście uzależnione od pobudek, jakimi kieruje się osoba podróżująca. Przy ustalaniu funkcji oporu należy zwrócić uwagę m.in. na to, czy badany jest transport pasażerski czy towarowy, za pomocą jakiej gałęzi transportu będzie realizowany, kto jest jego użytkowaniem (jakie ma cechy) oraz oczywiście, co skłoniło go do podróży. W transporcie pasażerskim wyróżnić można sześć podstawowych celów podróży: dojazdy do pracy, podróże służbowe i biznesowe, przejazdy w celach handlowych (zakupy), podróże związane z usługami służby zdrowia, edukacją i innymi, podróże rekreacyjne i turystyczne, wizyty (towarzyskie, rodzinne) (Sierpiński 2010).

Należy wskazać silny związek pomiędzy dostępnością potencjałową a modelami grawitacji, skutkujący niekiedy zamiennym stosowaniem nazw obydwu metod. Konieczne jest jednak wyraźne oddzielanie tych dwóch podejść. Modele potencjału prezentują potencjalne oddziaływanie określonej liczy mas na jedną masę. Modele grawitacji natomiast odnoszą się do bilateralnych oddziaływań mas (Chojnicki 1966).

$\mathrm{W}$ wielu polskich regionalnych opracowaniach analitycznych i strategicznych dostępność międzynarodowa regionów jest interpretowana w sposób obrazowy, ale uproszczony, oparty na wykazaniu istnienia lub braku fizycznych połączeń transportowych w określonych kierunkach geograficznych w świetle stanu istniejącej sieci i węzłów infrastruktury transportowej. Taka forma interpretacji dostępności transportowej nie wystarcza jednak do ustalenia priorytetów realizacji inwestycji infrastrukturalnych $w$ transporcie, gdyż nie bierze pod uwagę istotności siły grawitacji między poszczególnymi obszarami lub miejscami (Diagnoza polskiego transportu 2011). 
Dostępność obliczana za pomocą metod potencjału posiada wiele zalet. Przede wszystkim bierze pod uwagę relacje pomiędzy użytkowaniem przestrzeni a komponentem transportowym, pomijane przy pomiarze odległości czy stosowaniu izochron. Dostępność potencjalna to podejście stosunkowo łatwe w obliczeniach i powszechnie wykorzystywane na poziomie analiz regionalnych, krajowych i międzynarodowych.

Wadą tej metody określania dostępności jest natomiast konieczność wyważonego doboru zastosowanej funkcji, parametrów oporu przestrzeni czy elementów określających masę, ponieważ metody potencjału są na nie wysoce wrażliwe i w istotny sposób mogą wpływać na finalne wyniki. Trudności może nastręczać również interpretacja uzyskanych wyników analizy. Dostępność w ujęciu potencjałowym nie przyjmuje bowiem konkretnej jednostki. Rozwiązaniem może być interpretacja wyników na zasadzie porównań między analizowanymi obiektami lub zmian w czasie. Mimo tej trudności interpretacyjnej, metody te stanowią najbardziej obiektywną przesłankę do podejmowania decyzji w zakresie kierunków rozwoju sieci infrastruktury transportowej (ibid.).

Dostępność potencjałowa znalazła również zastosowanie w niniejszym opracowaniu. Posłużyła do określenia potencjału każdego z 44 miast województwa łódzkiego. Atrakcyjność stanowił syntetyczny wskaźnik uzyskany za pomocą odpowiednio ważonej sumy zmiennych, takich jak liczba ludności czy ranga administracyjna. Opór stanowiły, odpowiednio dla każdego środka transportu, odległości fizyczne rzeczywiste ustalane po drogach, torach kolejowych i tramwajowych. Określono także bilateralne oddziaływanie wszystkich 946 par miast.

Pomiary dostępności wykonywane są również w geografii czasu lub czasoprzestrzeni, nazywanej dostępnością spersonifikowaną (Rosik 2012), która oparta jest na koncepcjach pochodzących z lat siedemdziesiątych ubiegłego wieku, sformułowanych przez Hägerstranda. Odwoływały się one do indywidualnych cech każdego użytkownika, przedstawiając m.in. dzienne ścieżki życia czy też dostępność dzienną (daily accessibility), pokazującą możliwości dziennych podróży między określonymi destynacjami (najczęściej w transporcie publicznym). Modele te są również określane jako bazujące na zachowaniu użytkownika sieci. Obserwowany jest jego harmonogram działań, który określić ma znaczenie wymiaru czasowego i przestrzennego, a przede wszystkim ograniczeń czasowych i przestrzennych w dostępności transportowej. Do elementów ograniczających należy zaliczyć wszelkie aktywności użytkownika sieci, które są wykonywane w ramach jego obowiązków. Wszystkie pozostałe to czynności dobrowolne, czyli np.: wyjazdy wakacyjne, zakupy czy spotkania towarzyskie. Bardzo ważnym elementem tej grupy metod jest Przestrzeń Potencjalnych Ścieżek. Przyjmuje się, że ukazuje ona przestrzeń, jaką dysponuje użytkownik sieci w określonym czasie. Neutens i in. (2008) wskazują cztery elementy kształtujące powierzchnię potencjalnych ścieżek. Po pierwsze jest to lokalizacja kotwiczna, czyli miejsce wykonywania czynności obowiązkowych. Duże oddziaływanie ma również zakres 
czasu możliwy do wykorzystania przez użytkownika na czynności dobrowolne. Kolejny element kształtujący ścieżki to prędkości poruszania się, jakie użytkownik może osiągać przy określonych warunkach drogowych. Ostatni czynnik to niezbędny czas, jaki potrzebuje użytkownik na wykonanie czynności (dobrowolnych i obowiązkowych). Mocną stroną dostępności transportowej określanej w geografii czasu i czasoprzestrzeni jest uchwycenie aktywności (jej ograniczeń i motywacji) użytkowników sieci biorącej pod uwagę ich zróżnicowanie płciowe, wiekowe czy ekonomiczne. Trudności natomiast nastręcza pozyskanie danych tak dokładnych i wnikliwych, jak codzienny plan zajęć określonego użytkownika sieci.

Ostatnia grupa metod określa dostępność transportową na podstawie maksymalizacji użyteczności. Jest to koncepcja bazująca na dostępności indywidualnej, wyznaczanej na podstawie zachowań użytkownika systemu. Uwzględnia tym samym komponent indywidualny. Jest to nawiązanie do modelowania popytu na transport i teorii użyteczności, czym wprost nawiązuje do teorii mikroekonomii. Dostępność postrzega się jako wynik wyboru spośród wielu rozwiązań transportowych. Każda z tych możliwości jest jednym ze sposobów zaspokojenia określonej potrzeby użytkownika. Dynamiczny rozwój powyższych metod spowodował ich połączenie z modelami geografii czasu. Badania nad dostępnością ujętą maksymalną użytecznością dowodzą, że wzrost dostępności nie pozostaje ze wzrostem korzyści dla użytkownika w relacji liniowej. Mocną stroną stosowania tej grupy metod jest oparcie na indywidualnych zachowaniach użytkowników sieci, co jednak pociąga za sobą trudności w pozyskiwaniu danych.

Odpowiedzią na niedoskonałości i ograniczenia towarzyszące dotychczas stosowanym metodom był Wskaźnik Międzygałęziowej Dostępności Transportowej zaproponowany przez zespół badawczy IGiPZ PAN (Komornicki i in. 2008, 2009). Metoda miała na celu wskazanie nowych, bardziej poprawnych metodologicznie i metodycznie rozwiązań. Wprowadzono zróżnicowanie wagi dostępności badanych ośrodków, uzależniając je od ich roli w systemie społeczno-ekonomicznym i osadniczym badanego obszaru (większy wpływ na ogólny wskaźnik ma dostępność do tych ośrodków, których pozycja w systemie osadniczym i społeczno-ekonomicznym kraju jest wyższa). Metoda zakładała, że dostępność transportową należy wyrażać w jednostkach czasu oraz konieczne jest uwzględnianie każdego połączenia pomiędzy odpowiednio ważonymi elementami węzłowymi sieci. Dlatego też należy uznać, że wskaźnik międzygałęziowej dostępności transportowej jest pokrewny dostępności potencjałowej. Metoda uwzględnia również udział poszczególnych rodzajów transportu (drogowy, kolejowy, lotniczy i żegluga śródlądowa), ustalając ich proporcje za pomocą wag odzwierciedlających pracę przewozową. Miara może być obliczona oddzielnie dla transportu towarów i pasażerów. Efektem obliczeń jest wskaźnik syntetyczny, obrazujący swego rodzaju sprawność lub efektywność całego analizowanego układu lub systemu społeczno-gospodarczego, pod względem jego wewnętrznej struktury, powodującej 
taką, a nie inną, jego dostępność wzajemną (ibid.). Ze względów praktycznych na potrzeby obliczeń związanych z zastosowaniem wskaźnika międzygałęziowej dostępności transportowej przygotowano oryginalny program komputerowy.

Wynikiem kontynuacji prac zespołu badawczego IGiPZ PAN jest nowa wersja powyższej aplikacji o nazwie Open Graph Accessibility Model (OGAM). Zasadniczym celem prac nad narzędziem była poprawa jego funkcjonalności oraz rozszerzenie możliwości. OGAM jest aplikacją zbudowaną na teorii grafów i umożliwia obliczanie wskaźników dostępności potencjałowej na dowolnej sieci opracowanej uprzednio w oprogramowaniu Geographic Information System (GIS). Jest również powszechnie dostępna (np. za pośrednictwem witryny poświęconej dostępności transportowej www.igipz.pan.pl/accessibility/pl). Program OGAM wykorzystuje się do modelowania dostępności potencjałowej w oparciu o strukturę grafu. Autorzy programu twierdzą, że zagadnienia transportowe stanowią jedynie część możliwych zastosowań narzędzia. Grafowa dostępność potencjałowa łączy koncepcję potencjału z praktyką dotyczącą działania połączeń komunikacyjnych. Praca programu rozpoczyna się od określenia potencjału w danej lokalizacji na podstawie sumy natężeń zjawiska w otaczających miejscach, „uwzględnionych w stopniu proporcjonalnym do bliskości owych miejsc" do badanej lokalizacji. Grafowa dostępność potencjałowa wykorzystuje dane o zgeneralizowanym koszcie przemieszczania się, których dokładność znacznie przewyższa teorię potencjału w jej tradycyjnej formie (Rosik i in. 2012).

Na potrzeby niniejszej pracy została stworzona nowa metoda badawcza dostępności transportowej, bazująca na wykorzystaniu nowoczesnych technologii i powszechnie dostępnych informacji. Za dane wejściowe posłużyły raporty wysyłane przez czujniki rozmieszczone na drogach, informacje od korporacji taksówkarskich, serwisów rządowych, prywatnych dystrybutorów baz danych oraz przede wszystkim anonimowo przez użytkowników mobilnej wersji Google Maps dla systemów Android, IOS, Symbian, Windows Phone i innych. Zasób tych danych nie wyczerpuje oczywiście informacji na temat wszystkich użytkowników dróg, ale powszechność wymienionych urządzeń, a także coroczne przyrosty ich użytkowników w Polsce pozwalają takie źródło informacji uważać za wielce wiarygodne (www.deloitte.com.pl). Program umożliwia bez potrzeby prowadzenia bardzo kosztownych badań bezpośrednich na precyzyjne i rzeczywiste określenie takich zjawisk, jak natężenie i średnia prędkość przemieszczania się w transporcie samochodowym. Odpowiednio zastosowana metoda pozwala na zastąpienie obecnie jednego źródła wiedzy na temat natężenia ruchu w transporcie samochodowym, jakim jest Generalny Pomiar Ruchu przeprowadzany przez GDDKiA. Przewaga proponowanego podejścia polega na możliwości ciągłego monitoringu zjawiska oraz wielokrotnie niższych kosztów potrzebnych do jego realizacji. W oparciu o analizę potoków ruchu na drogach krajowych i wojewódzkich możliwe było określenie rzeczywistych prędkości przejazdu pomiędzy miastami województwa łódzkiego. 
Zakres stosowania metody badawczej jest bardzo szeroki (ograniczenia wynikają z obostrzeń licencyjnych oraz stopnia optymalizacji urządzenia) i zależy jedynie od przyjętego przez badaczy podmiotu badania. Aktualne ograniczenia w pozyskiwaniu danych, związane z polityką prywatności prowadzonej przez ich dysponentów, nie pozwalają na pełne wykorzystanie możliwości programu. Przy uzyskaniu danych w postaci wektorów przemieszczeń poszczególnych użytkowników sieci (w postaci bazy danych) możliwe jest nawiązanie do geografii czasu i czasoprzestrzeni czy maksymalizacji użytkowania. Byłaby wtedy sposobność prześledzenia ruchu poszczególnych użytkowników sieci. Bardzo mało prawdopodobne wydaje się uzyskanie od operatorów sieci komórkowych czy firm budujących aplikacje nawigacyjne najogólniejszych danych określających użytkowników (pozyskanych np. z formularzy wypełnianych przy zakupie licencji). Jednakże możliwe jest ich otrzymanie w sposób pośredni poprzez analizę miejsc początku podróży i jej zakończenia.

Zestaw metod przeznaczonych do określania dostępności transportowej, wykorzystywany przez środowiska polityczne, jest w wielu przypadkach zbyt wąski i nieodpowiadający wielowymiarowości badanego zjawiska. Pomiary poziomu kongestii czy wytyczenie izochron od głównych ośrodków miejskich, stosowane przez planistów, pozwalają scharakteryzować system transportowy, jednakże nie skupiają się w żaden sposób na użytkowaniu przestrzeni. Planowanie przestrzenne, w którym szeroko ujmowana dostępność transportowa jest jednym z podstawowych zagadnień, ogniskuje swoją uwagę na zmiennych związanych z użytkowaniem przestrzeni, pomijając niekiedy relacje funkcjonalne pomiędzy ośrodkami. Instytut Badań nad Gospodarką Rynkową przygotował analizy dostępności transportowej polskich regionów, uzależnione m.in. od rodzaju działalności gospodarczej, prowadzonej w danym regionie (inne są potrzeby komunikacyjne w regionach, gdzie przeważa działalność przemysłowa, inne w regionach o przewadze działalności usługowej i produkcji zaawansowanej technologicznie). Tego typu branżowe podejścia do dostępności transportowej są zapewne skutkiem wciąż niskiego poziomu świadomości różnorodności ścieżek jej pomiaru (Komornicki i in. 2009).

\subsection{Uwarunkowania dostępności transportowej}

Ustalenie dokładnej i wyczerpującej listy uwarunkowań kształtujących dostępność transportową jest zadaniem niezwykle skomplikowanym. Wynika to z mnogości czynników, które wpływają na projektowanie i wdrażanie infrastruktury transportowej oraz przemieszczanie się pojazdów, mające często charakter losowy. Dla przykładu, przy opracowywaniu modeli ruchu (w związku z opty- 
malizacją układów drogowych) brane są pod uwagę m.in. takie zmienne, jak liczba pasów danego odcinka drogi, jego krętość, strome podjazdy czy promienie zakrętów (Rosik, Śleszyński 2009). Ujmowany jest też wpływ warunków pogodowych, natężenie ruchu i oczywiście ograniczenia wynikające z zapisów prawa o ruchu drogowym. Nie należy pomijać również zmiennych związanych z indywidualnymi użytkownikami sieci. Każdy z nich może poruszać się pojazdem o innej charakterystyce (dotyczy to również komunikacji zbiorowej, gdzie zróżnicowanie pojazdów jest znaczne) i prowadzić go w tylko sobie charakterystyczny sposób. Samego użytkownika sieci można scharakteryzować pod kątem m.in. wieku, płci, stanu zdrowia, dochodu, wykształcenia, narodowości i wielu innych cech szczególnych, które wpływają na jego ruchliwość. Możliwości użytkownika sieci zależą ponadto od zdolności potrzebnych do podróżowania (np. posiadanie prawa jazdy).

Komornicki i in. (2009) podkreślają, że przy badaniach prowadzonych w dużej skali (międzynarodowej, krajowej) wymienione zmienne „wzajemnie się znoszą". Ponadto konieczna jest pewna generalizacja, wynikająca $\mathrm{z}$ technicznej niemożności ujęcia wszystkich zmiennych.

Przed przejściem do etapu różnicowania zmiennych warunkujących poziom dostępności transportowej konieczne jest przyjęcie założenia wstępnego. Wszystkie przyjęte czynniki dotyczą realizacji transportu w granicach kraju. Zakładając przemieszczanie się poza jego granice (niezależnie od tego, która z granic jest przekraczana, czy przemieszczenie dotyczy państw objętych traktatem z Schengen czy też nie), pojawia się szeroki zakres dodatkowych barier dostępności. Wyczerpująco przedstawia je Rosik (2012), badając lądową dostępność przestrzeni Polski w wymiarze europejskim. Warto zaznaczyć, że w przypadku powiązań międzynarodowych istnieją $\mathrm{w}$ mniejszym lub większym stopniu ograniczenia i bariery o charakterze politycznym, ekonomicznym, prawnym, kulturalnym i językowym. Ograniczenia te wpływają na wydłużenie czasu przejazdu (np. czas oczekiwania na granicy).

Należy ponadto podkreślić, że charakteryzowane poniżej komponenty (w tym komponenty środowiskowe) mają wpływ na prędkość podróżowania w konkretnym miejscu i czasie. Ich oddziaływanie na miary dostępności jest jednak w niektórych wypadkach jedynie pośrednie. Przez uwarunkowania dostępności, a zwłaszcza w ujęciu potencjałowym, należy rozumieć podstawowe komponenty wzmiankowanych już wskaźników, a mianowicie stan infrastruktury, gęstość zaludnienia, rozmieszczenie mas i cele podróży. Dodatkowo odniesiono się do uwarunkowań rozwoju sieci transportowej i lokalnej prędkości ruchu znacząco determinujących poziom dostępności.

Dla przejrzystego ujęcia tak szerokiej grupy elementów konieczna jest ich strukturyzacja (rycina 1.3). Pierwsza zasadnicza linia podziału dotyczy roli człowieka i jego działalności, i wydziela dwa zbiory czynników - przyrodnicze (naturalne) $\mathrm{i}$ antropogeniczne. 


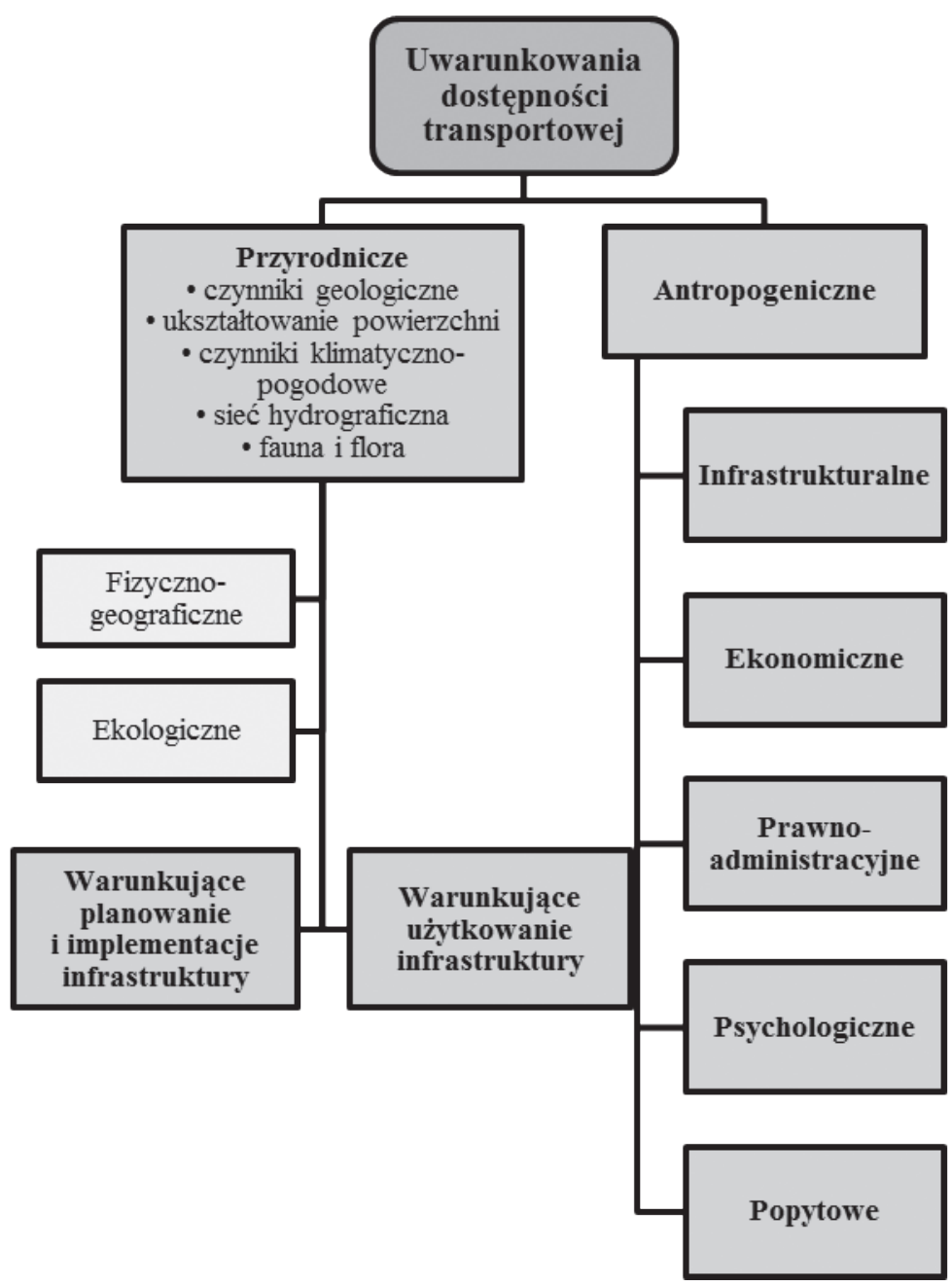

Rycina 1.3. Struktura uwarunkowań dostępności transportowej

Źródło: opracowanie własne na podstawie Mazur (1998), Komornicki i in. (2009), Rosik (2012)

Bariery przyrodnicze stanowią ograniczenie fizyczno-geograficzne oraz często również ekologiczne, rozumiane jako trudności w szybkim podróżowaniu przez obszar parków narodowych czy krajobrazowych (ibid.). Należy także podkreślić, że uwarunkowania przyrodnicze wpływają przede wszystkim na rozkład infrastruktury, a dopiero ta kształtuje dostępność. Funkcjonowanie każdej gałęzi transportu ma miejsce w określonych uwarunkowaniach środowiska przyrodniczego, pozostając z nim w silnych relacjach. Oddziaływanie poszczególnych elementów środowiska można zaobserwować zarówno na etapie projektowania i implementacji infrastruktury transportowej, jak również podczas realizacji po- 
trzeb transportowych. Uwidacznia się to chociażby przy wyborze optymalnej trasy przewozu pasażerów czy ładunków. Nie oznacza to jednak, że należy przypisywać środowisku przyrodniczemu najważniejszą rolę w kreowaniu polityki transportowej, choć jego wpływ jest wyraźny w każdej formie transportu (Lijewski 1986). Duże zróżnicowanie cech środowiska przyrodniczego powinno skutkować analizą jego oddziaływania wykonywaną dwupłaszczyznowo - jako stymulanty i destymulanty rozwoju transportu.

Berezowski (1975) ukazuje pozytywny wpływ warunków środowiska przyrodniczego na transport, m.in. w postaci pionowego ukształtowania terenu bez dużych różnic wysokości względnych. Wymienia również brak elementów sieci hydrograficznej, bagien czy torfowisk, które przecinałyby szlak transportowy. Wskazuje ponadto na stymulanty w postaci dobrych warunków atmosferycznych czy występowania na określonym obszarze materiałów budowlanych, niezbędnych do budowy infrastruktury.

Środowiskowe destymulanty rozwoju transportu to m.in. konieczność pokonywania dużych pochyłości terenu czy objeżdżania elementów sieci hydrograficznych. Przeszkodę stanowią również niesprzyjające warunki pogodowe skutkujące np. podmywaniem dróg i torowisk. Znaczną część przeszkód środowiskowych utrudniających dostępność transportową można zlikwidować lub znacznie ograniczyć dzięki zastosowaniu odpowiednio zaawansowanych technik i technologii projektowania, budowy i eksploatacji infrastruktury transportowej (Mazur 1998).

Pokonywanie przeszkód stawianych przez warunki naturalne powoduje nie tylko zmiany krajobrazu, ale również znaczne zwiększenie kosztów budowy i eksploatacji szlaku transportowego (Kręgielewski 1979). Czynniki środowiskowe warunkujące dostępność transportową zaczęły tracić na znaczeniu wraz z dynamicznym rozwojem techniki (Leszczycki 1971). Przemieszczanie stało się możliwe i znacznie bardziej komfortowe nawet wbrew najdotkliwszym przeszkodom terenowym. Aktualnie konieczne jest stałe przystosowywanie sieci infrastruktury transportowej do zwiększającej się liczby użytkowników, pociągające za sobą dalsze relacje na styku środowiska przyrodniczego i dostępności transportowej.

Pod względem geologicznym rozwój budownictwa transportowego jest warunkowany m.in. odpornością skał, ich ułożeniem czy składem chemicznym. Jak już wspomniano, wspierająca rola uwarunkowań geologicznych może uwidocznić się poprzez zapewnienie odpowiednich skał jako budulca nowych odcinków sieci (Tylutki 1975).

Ze wszystkich czynników środowiskowych najistotniejszy wpływ na lokalizowanie szlaków komunikacyjnych i funkcjonowanie transportu ma ukształtowanie powierzchni. Szczególnie wrażliwe na urozmaicenie terenu są koleje. Nawet niewielkie pochylenie toru zmniejsza szybkość pociągu i powoduje znaczy wzrost zużycia energii (Madeyski i in. 1975). Dlatego też linie kolejowe trasuje się tak, aby omijały wzniesienia. Wprowadzane są również różnego rodzaju zabiegi w po- 
staci nasypów lub wykopów, które niwelują wpływ ukształtowania powierzchni na realizację transportu.

Kolejnym elementem wpływającym na poziom dostępności transportowej są warunki klimatyczno-pogodowe. W znacznym zakresie warunkują wprowadzenie infrastruktury w przestrzeń geograficzną oraz późniejsze jej funkcjonowanie. Zdecydowanie najsilniejszy wpływ $\mathrm{w}$ tym zakresie uwidacznia się w przypadku transportu lotniczego, zarówno co do realizacji lotów, jak i lokalizacji punktowych elementów infrastruktury (lotnisk, lądowisk). Nie należy jednak deprecjonować wpływu uwarunkowań klimatyczno-pogodowych na realizację transportu lądowego. Rozmakanie dróg czy podmywanie torów to tylko przykłady tego typu oddziaływania, znacznie utrudniające dotarcie do przyjętego celu podróży. Zbyt wysokie lub niskie temperatury powietrza również mogą sprawiać problemy w transporcie kolejowym czy samochodowym. Odkształcenia szyn kolejowych i nawierzchnie asfaltowe rozmiękczone zbyt wysokimi temperaturami skutecznie utrudniają funkcjonowanie transportu. $\mathrm{Z}$ kolei zbyt niskie temperatury przyczyniają się do pękania torów i powstawania wyrw w nawierzchniach transportowych poprzez naprzemienne zamarzanie i tajenie wody znajdującej się w jej zagłębieniach (Mazur 1998).

Następnym elementem mającym duży wpływ na działalność transportu, a co za tym idzie poziom dostępności, są opady atmosferyczne. Ze wszystkich ich rodzajów najbardziej znaczące są deszcz i śnieg ze względu na ich największą częstotliwość występowania. Ulewy, jak już wspomniano, niszczą odcinki dróg kołowych i kolejowych poprzez podmycia czy rozmycia (Mazur 1985). Dużym problemem są również zalegające na drogach i liniach kolejowych pokrywy śnieżne. Bardzo groźne dla funkcjonowania transportu są ponadto gołoledź i (osadzająca się na drogach czy trakcji) szadź.

Elementy sieci hydrograficznej również nie są łatwą przeszkodą do pokonywania przez transport. Trudności sprawiają przede wszystkim wielkie rzeki nizinne, płynące szerokimi, podmokłymi dolinami lub pradolinami. Uciążliwymi przeszkodami w lokalizacji elementów sieci transportowej są również jeziora. Szczególnie problematyczne w tym względzie są jeziora rynnowe pochodzenia polodowcowego. Ich znaczna długość powoduje wyraźne zmiany przebiegu dróg w stosunku do przebiegu prostoliniowego (Mazur 1998).

Rodzaj gleb ma także pewien wpływ na przebieg linii komunikacyjnych. Dotyczy to sytuacji, gdy na trasie przebiegu planowanej drogi czy linii kolejowej znajdują się gleby bagienne, piaskowe lub lessowe, a więc grunty słabonośne. Innym zagadnieniem są obszary występowania gleb najbardziej wartościowych. Będąc chronione odpowiednimi zapisami prawa, powinny być wyłączane spod zabudowy komunikacyjnej (Jakubowski 1976).

Powszechne są również trudności na styku wprowadzania elementów sieci transportowej i miejsc występowania określonej szaty roślinnej czy siedlisk zwierząt. Wielkoobszarowe skupiska leśne utrudniają znacząco trasowanie dróg 
czy linii kolejowych. Stosowanie obejść znacznie odchyla przebieg drogi czy linii kolejowej od ich pierwotnie prostoliniowego charakteru. Ponadto na drogach prowadzących przez tereny leśne częściej występują utrudnienia w ruchu wynikające z potrzeby prowadzenia remontów. Ponieważ panująca na tych terenach większa wilgotność powietrza i większe opady negatywnie oddziałują na stan techniczny infrastruktury (Grzywacz 1982). Zagrożeniem dla płynności funkcjonowania transportu są również wypadki związane z ruchliwością zwierząt. Występują one rzecz jasna najczęściej na terenach leśnych, które zamieszkuje najwięcej gatunków.

Drugą główną grupą elementów wpływających na poziom dostępności są bariery o charakterze antropogenicznym. Niektóre z tych uwarunkowań, takie jak poziom wzrostu gospodarczego czy też dochody budżetu gminy, mają w znacznej mierze znaczenie pośrednie w stosunku do poziomu dostępności, bowiem od nich zależy możliwość podejmowania nowych inwestycji infrastrukturalnych, odpowiednio, w skali kraju i jednostki lokalnej.

Biorąc pod uwagę polskie warunki, jedyną poważną barierą tego typu jest stan infrastruktury transportowej zarówno w ujęciu jakościowym, jak i ilościowym (Rosik 2012). Występuje oczywiście szereg innych elementów wynikających z działalności człowieka, a warunkujących przemieszczanie się ludzi i ładunków. Komornicki (1999) wyróżnił poza czynnikami infrastrukturalnymi również prawne, ekonomiczne i psychologiczne. Występowanie każdego z typów czynników w charakterze bariery wiąże się ze zmniejszaniem atrakcyjności celu podróży - obniża się ich dostępność. W nielicznych przypadkach czynniki te mogą występować w roli stymulatorów podróży. Są to jednak zazwyczaj elementy silnie związane z konkretnym użytkownikiem sieci, np. posiadanie rodziny w danym mieście lub sentyment dla konkretnego miejsca.

Bariery infrastrukturalne (techniczne) w jeszcze większym zakresie niż przyrodnicze są możliwe do zmniejszenia lub likwidacji. Wynika to jedynie z postępu technologicznego i dostępności funduszy ${ }^{1}$. Dzięki nowym inwestycjom oraz naprawom i modernizacjom elementów już istniejących możliwe jest podnoszenie poziomu dostępności transportowej. Znaczne korzyści w tym względzie może przynieść również wprowadzanie zoptymalizowanych rozwiązań organizacyjnych w zakresie realizacji transportu. Szczególnie ważne jest implementowanie infrastruktury umożliwiającej podróż z wysokimi prędkościami - autostrady, drogi ekspresowe, koleje dużych prędkości. Możliwość szybkiego, komfortowego i bezpiecznego przemieszczania się może być przesłanką do odbycia podróży do określonego celu. Rosik (2012) wskazuje w związku z tym na zjawisko ruchu

${ }^{1} \mathrm{~W}$ przypadku dróg o wyższych kategoriach wprowadza się rozwiązania mające na celu urozmaicenie warunków jazdy przeciwdziałających znużeniu i zaśnięciu kierowców. W polskich warunkach tego typu rozwiązania nie są praktykowane, co wynika z naturalnego urozmaicenia uwarunkowań przyrodniczych wpływających na przebieg infrastruktury (Komornicki i in. 2009). 
wzbudzonego, powstającego na skutek wprowadzania do sieci elementów infrastruktury o wyższych klasach.

Odrębnym, ale równie ważnym elementem warunkującym dostępność transportową, a związanym ze stanem infrastruktury, jest kreowana polityka transportowa i realizacja planowanych w niej inwestycji transportowych (sieci transportowych i taboru ujętych $\mathrm{w}$ krajowych i regionalnych strategiach, planach i programach). Kompetencje w zakresie prowadzenia polityki dotyczącej transportu i sieci transeuropejskich dzieli z Polską (państwem członkowskim) również Unia Europejska (na podstawie art. 4 Traktatu o funkcjonowaniu Unii Europejskiej, dalej: TFUE). Prowadzenie polityki transportowej i polityki w zakresie sieci transeuropejskich wynika m.in. z konieczności zapewnienia swobodnego przepływu towarów i osób. Wynika także z dążenia do spójności gospodarczej, społecznej i terytorialnej oraz harmonijnego rozwoju całego obszaru Unii Europejskiej (Napierała i in. 2013). W takim ujęciu również polityka międzynarodowa warunkuje dostępność rozpatrywaną w zakresie niniejszego opracowania. Bardzo istotne jest wprowadzanie rozwiązań innowacyjnych i zaawansowanych technologii w zarządzaniu transportem, zastosowanie Inteligentnych Systemów Transportowych (ITS) (Adamski 2003) czy wprowadzenie nowych technologii w środkach transportu (wymiana taboru) (Michalski 2010).

Kolejna grupa czynników mających wpływ na dostępność transportową to bariery prawno-administracyjne. Wynikają one m.in. z konieczności uzyskania odpowiednich koncesji i zezwoleń, jak w przypadku prowadzenia działalności związanej z przewozem ludzi. Na swobodne funkcjonowanie transportu wpływają także zasady ruchu pojazdów zgodnie z przepisami prawa o ruchu drogowym (m.in. przestrzeganie prędkości na drogach o różnym statusie czy w obszarze zabudowanym) czy obostrzeń wynikających ze stanu infrastruktury (jak w przypadku kolei). Realizację transportu warunkują również przepisy egzekwujące odpowiedni stan techniczny pojazdów czy jak w przypadku transportu towarowego - maksymalnej ładowności, czy zakaz ruchu podczas świąt i weekendów. Na styku czynników prawno-administracyjnych i infrastrukturalnych można też wymienić poziom planowania przestrzennego. Brak planów zagospodarowania przestrzennego stanowi istotne utrudnienie $\mathrm{w}$ procesie wdrażania infrastruktury transportowej (Komornicki 2007).

Uwarunkowania ekonomiczne dostępności transportowej stanowią w dużej mierze pochodną ograniczeń formalnoprawnych (Komornicki 1999). Są zatem powiązane ze wszelkiego rodzaju opłatami. Rosik (2012) wymienia m.in. koncesje czy zezwolenia na wykonywanie usług transportowych. Dodatkowe koszty są związane z użytkowaniem infrastruktury, jak w przypadku opłat autostradowych czy systemu viaTOLL ${ }^{2}$. Ponadto wymienić należy ceny biletów w komunikacji

${ }^{2}$ Funkcjonujący w Polsce elektroniczny system poboru opłat za poruszanie się po drogach krajowych. Opłatą są objęte wszystkie pojazdy samochodowe o dopuszczalnej masie całkowitej przekra- 
zbiorowej i przede wszystkim zakup paliwa w przypadku indywidualnego transportu samochodowego. Wraz z ogólnym wzrostem zamożności społeczeństwa podnosi się poziom motoryzacji i mobilności (Komornicki i in. 2009), co ułatwia osiąganie celów podróży, ale w przypadku niedostosowania infrastruktury do zwiększonego popytu skutkuje wzmożoną kongestią. Wysokości dochodów, a przede wszystkim ich części przeznaczane na podróże, warunkują również wybór sposobu poruszania się. Użytkownicy o relatywnie niskich dochodach (bądź zmuszeni wykorzystywać je w inny sposób) często pozbawieni są możliwości wyboru środka transportu - jest zdeterminowany niską ceną. W związku z tym w większości przypadków jedyną możliwością jest transport publiczny (Geurs, Ritsema van Eck 2001).

Kolejna grupa elementów mogących ograniczać dostępność transportową to bariery psychologiczne. Ich źródeł należy upatrywać w dużej mierze we wspomnianych wcześniej uwarunkowaniach prawno-administracyjnych, ekonomicznych i infrastrukturalnych. Zniechęcać do podróży mogą zbyt duże koszty, zły stan infrastruktury czy konieczność stania w korkach. Rosik (2012) podaje również poziom przestępczości, jako element warunkujący dostępność celu podróży.

Przy ustalaniu zmiennych warunkujących prędkość jazdy samochodem, pośrednio dotyczących poziomu dostępności, Komornicki i in. (2009) wskazali na czynnik popytowy, odnoszący się do przestrzennego zróżnicowania rozmieszczenia ludności. Można jednak domniemywać, że wzmożony ruch w pobliżu dużych skupisk ludzkich nie wpływa wyłącznie na płynność ruchu samochodów, ale również tramwajów (w związku ze skrzyżowaniami z ruchem samochodowym i zwiększoną liczbą przystanków) i pociągów (linie przechodzące przez miasto prowadzą ruch odpowiednio wolniej niż na terenach poza nim³).

Dodatkowo, jeżeli rozpatrywane jest natężenie ruchu pojazdów, należy jako zmienną przyjąć także porę dnia, tygodnia i roku (komponent czasowy), które wpływają na poziom dostępności transportowej (Baradaran, Ramjerdi 2001). Przy podróżach na dłuższych dystansach ten wpływ jest niewielki, natomiast znacznie większą rolę mu się przypisuje na krótszych odcinkach.

Poza ograniczeniami dostępności transportowej wynikającymi z utrudnień w ruchu w obszarze gęsto zaludnionym (szczególnie jeśli taki obszar nie stanowi celu, lecz znajduje się na drodze do niego prowadzącej), skupiska ludzkie stanowią również cel o wysokiej atrakcyjności, która podobnie jak transport jest

czającej 3,5 t. System obejmuje również autobusy bez względu na ich masę całkowitą. Inne pojazdy mogą fakultatywnie włączyć się do systemu viaAUTO, co spowoduje automatyczne naliczenie opłaty w wyznaczonych miejscach poboru opłat. Takie rozwiązanie znacznie usprawnia korzystanie z dróg płatnych, gdzie tradycyjnie konieczna jest opłata gotówką lub kartą (www.gddkia.gov.pl).

${ }^{3}$ Do ustalenia różnic prędkości posłużył załącznik nr 2.1 do regulaminu przydzielania tras pociągów i korzystania z przydzielonych tras pociągów przez licencjonowanych przewoźników kolejowych w ramach rj 2012/2013 - Wykaz maksymalnych prędkości-pociagi pasażerskie (PKP Polskie Linie Kolejowe SA). 
warunkowana wieloma czynnikami (m.in. ilością i strukturą dostępnych funkcji egzogenicznych). Jak podkreślają Helliwell i Schembri (2005) czy Komornicki (1999), zmiana atrakcyjności celu podróży może bezpośrednio wpływać na wielkość potoków ruchu i jednocześnie warunkować jego dostępność transportową (Spiekermann, Neubauer 2002). Zróżnicowanie atrakcyjności może wynikać m.in. $z$ rodzaju analizowanej gałęzi transportu, wybranego środka transportu oraz komponentu indywidualnego każdego z użytkowników.

Holistyczne ujęcie czynników warunkujących dostępność transportową określonego celu powinno odwoływać się do zagospodarowania przestrzennego (komponent przestrzenny), systemu transportowego (komponent transportowy), ale również do cech społeczno-ekonomicznych użytkowników (komponent indywidualny), które obsadzone są w konkretnym momencie czasowym podróży (komponent czasowy). Różnorodność zmiennych w każdej z grup czynników zmusza do stosowania uproszczeń i przyjmowania a priori pewnych założeń z jednej strony, z drugiej zaś daje duże pole manewru przy formułowaniu różnego rodzaju modeli i symulacji.

\subsection{Dostępność transportowa w świetle dokumentów strategicznych}

Dostępność transportowa jest pojęciem powszechnie używanym w różnorodnych koncepcjach zagospodarowania przestrzennego, wieloletnich programach inwestycyjnych, opracowaniach ewaluacyjnych, analizach branżowych i wielu innych dokumentach na każdym ze szczebli administrowania. Przegląd tego typu opracowań na poziomie międzynarodowym, krajowym i regionalnym ${ }^{4}$ pozwala określić wagę, jaką przywiązują decydenci do tematyki dostępności transportowej. Zapisy dokumentów o charakterze holistycznym, zawężonych wyłącznie do dziedziny transportu, w zróżnicowany sposób ujmują rolę tego czynnika i różnie definiują zadania zmierzające do jego rozwoju.

$\mathrm{Na}$ poziomie analiz międzynarodowych odwołano się do zapisów Polityki spójności Unii Europejskiej 2014-2020 oraz Białej księgi (2011). W propozycjach ustawodawczych dotyczących polityki spójności UE 2014-2020 nie widnieje bezpośrednie odniesienie do dostępności transportowej, natomiast jest wyraźny zapis o kontynuacji działań z zakresu polityki transportowej, ujętych w poprzednim okresie programowania $z$ jednoczesnym wprowadzeniem nowego instrumentu - „Lącząc Europę”5. Ma on stymulować m.in. realizację inwestycji z za-

${ }^{4}$ Ze względu na zakres przestrzenny niniejszej pracy do analizy wybrano dokumenty i opracowania, których zapisy w sposób bezpośredni lub pośredni obejmują województwo łódzkie.

${ }^{5}$ Propozycja utworzenia wspólnotowego instrumentu finansowania rozwoju transeuropejskich sieci (Fundusz „Łącząc Europę”) pojawiła się w komunikacie Komisji Europejskiej z dnia 19 paź- 
kresu transportu poprzez rozwój transeuropejskiej sieci transportowej (TEN-T, z ang. Trans-European Transport Networks $\left.{ }^{6}\right)$. W przypadku województwa łódzkiego taka deklaracja jest szczególnie ważna, gdyż elementy sieci transeuropejskiej stanowią istotną część regionalnej sieci infrastruktury transportowej. Fundusz Spójności pozwoli ponadto na ustawiczne wspieranie inwestycji w zakresie niskoemisyjnych systemów transportu oraz transportu miejskiego. Nowo powołany instrument polityki spójności wydaje się podkreślać rangę zadań związanych z transportem i łącznością w polityce Unii Europejskiej. W okresie 2007-2013 zadania te były narzędziami do realizacji trzech głównych celów polityki, a w nowej perspektywie zagadnienia komunikacyjne stały się celem samym w sobie.

Biała księga (2011), odnosząca się do planu utworzenia jednolitego europejskiego obszaru transportu, prezentuje dostępność (do infrastruktury) jako element mający pozytywny wpływ na wzrost gospodarczy, pozwalający na stworzenie dobrobytu i miejsc pracy, zwiększenie handlu, dostępności geograficznej i mobilności obywateli. Zwraca też uwagę na relację pomiędzy wysokim poziomem dostępności, wynikającym z wyposażenia infrastrukturalnego, a mobilnością. Dokument wspomina o konieczności prowadzenia polityki transportowej w sposób maksymalizujący pozytywny wpływ na wzrost gospodarczy i minimalizujący zatory komunikacyjne, będące dużym wyzwaniem zwłaszcza w transporcie lądowym oraz negatywnie wpływające na kwestię dostępności. Księga odnosi się również do dostępności usług transportowych. Ze względu na starzenie się społeczeństwa i potrzebę promowania transportu publicznego jest to szczególnie ważne. Według dokumentu, transport wysokiej jakości charakteryzuje się poza atrakcyjnym rozkładem jazdy czy komfortem, przede wszystkim dostępnością.

Na poziomie krajowym lista opracowań holistycznych i branżowych kreujących czy jedynie odwołujących się do tematyki dostępności transportowej jest bardzo długa. W pierwszej kolejności poddano analizie dokumenty strategiczne określające wielopłaszczyznowe wytyczne rozwoju państwa. Koncepcja przestrzennego zagospodarowania kraju 2030 (KPZP), jako jeden z celów polityki, zakłada poprawę dostępności terytorialnej kraju w różnych skalach przestrzen-

dziernika 2011 r. (COM/2011/676). W dokumencie wskazano najważniejsze aspekty niedorozwoju sieci transportowej w Europie: brak terytorialnej integralności, zasobooszczędności i interoperacyjności. Co ważniejsze, w komunikacie opisano założenia i narzędzia finansowania dostępne w ramach instrumentu „Łącząc Europę”. Przedstawiona w przywołanym komunikacie Komisji Europejskiej diagnoza stanu sieci transeuropejskich oraz koncepcja (co najistotniejsze) finansowania ich rozwoju stanowiły podstawę do przedstawienia wniosku Komisji Europejskiej o uchwalenie rozporządzenia Parlamentu Europejskiego i Rady ustanawiającego instrument „Łącząc Europę”.

${ }^{6}$ Sieci transeuropejskie tworzone są przez Unię Europejską w infrastrukturze transportowej obejmującej nie tylko infrastrukturę transportową, ale również systemy zarządzania ruchem oraz systemy geograficznego pozycjonowania. Na infrastrukturę transportową składają się sieci drogowe i kolejowe, sieci i porty żeglugi śródlądowej, autostrady morskie i porty żeglugi morskiej, porty lotnicze. Infrastrukturę transportową tworzą również inne węzły intermodalne i multimodalne, łączące wymienione rodzaje sieci (art. 3, 661/2010/UE). 
nych poprzez rozwijanie m.in. infrastruktury transportowej. Dokument podkreśla, że dotychczasowy poziom wzajemnej dostępności przestrzennej polskich ośrodków metropolitalnych i regionalnych jest niewystarczający dla potrzeb gospodarki o charakterze rynkowym. W skali obszarów funkcjonalnych dużych i średnich ośrodków problemy transportowe stanowią w myśl koncepcji jedną z głównych barier rozwojowych. Są istotnym ograniczeniem przestrzennego zwiększenia rynków pracy, a pośrednio z powodu braku rozwiązań w zakresie transportu publicznego sprzyjają niekontrolowanej suburbanizacji. W odniesieniu do systemu transportowego polityka przestrzennego zagospodarowania kraju przede wszystkim ma zmierzać do poprawy dostępności terytorialnej kraju, w różnych skalach przestrzennych. Będzie to osiągane w pierwszej kolejności poprzez przedefiniowanie hierarchii priorytetów inwestycyjnych w transporcie, w średniookresowych dokumentach strategicznych. Jako najważniejsze traktowane będą inwestycje transportowe służące poprawie dostępności wewnętrznej kraju, w tym zwłaszcza pomiędzy największymi ośrodkami metropolii sieciowej, do tych ośrodków i w obrębie ich obszarów funkcjonalnych. Jednym z czterech kierunków działań w ramach celu poświęconego poprawie dostępności terytorialnej jest wzrost dostępności polskich miast i regionów. Szczególnie istotny ze względu na tematykę niniejszej pracy wydaje się podpunkt 3.1.1 KPZK 2030, mówiący o poprawie wzajemnej dostępności głównych ośrodków miejskich. Działania na rzecz realizacji tego celu obejmują przede wszystkim polepszenie wzajemnej dostępności czasowej między ośrodkami. Koncepcja zakłada również wzrost dostępności polskich miast $\mathrm{w}$ przestrzeni europejskiej, poprawę dostępności ośrodków subregionalnych i obszarów wiejskich. W podpunkcie 3.1.4 dokumentu uwaga skupiona jest na postępie w zakresie dostępności do obszarów peryferyjnych o najniższym poziomie dostępności czasowej, do ośrodków metropolitalnych i innych głównych miast dzięki rozbudowie infrastruktury transportowej. W ramach kierunku działań poświęconemu poprawie dostępności znalazły się również zapisy mówiące o zmniejszeniu kosztów transportu. Ujęto w tym zakresie m.in. poprawę dostępności wewnątrz obszarów funkcjonalnych z preferencją dla rozwoju transportu publicznego. Realizacji celu służyć będzie doprowadzenie do obligatoryjnej współpracy gmin w obszarach funkcjonalnych w zakresie transportu miejskiego i podmiejskiego, wprowadzenie systemu opłat drogowych oraz rozwój systemów „parkuj i jedź” w ośrodkach powyżej 500 tys. mieszkańców. Nie precyzuje się jednak, w jaki sposób ma zostać osiągnięta wysoka dostępność transportowa małych ośrodków miejskich, wobec których z natury rzeczy konieczne jest stosowanie innych narzędzi niż dla dużych miast.

Dokument Polska 2030 - wyzwania rozwojowe, szeroko omawia dostępność transportową w ramach wyzwania 4: Odpowiedni potencjat infrastruktury. Zapisy dokumentu prezentują politykę transportową, mającą na celu wysoki poziom dostępności, jako sposób niwelowania skutków peryferyjnego położenia obszaru. Poziom potencjalnej dostępności transportowej jest przedstawia- 
ny jako istotny miernik rozwoju na poziomie regionalnym. Dokument wskazuje na niską dostępność transportową Polski i poszczególnych jej obszarów, będącą wynikiem słabości infrastruktury transportowej, która stanowi poważną barierę komunikacyjną. Dostępność transportową należy więc traktować jako czynnik stymulujący wzrost gospodarczy i przemiany cywilizacyjne, które - odpowiednio wykorzystane - mogą posłużyć jako mnożnik rozwojowy. Jednocześnie znosi on ograniczenia płynące z peryferyjności poszczególnych regionów oraz całości kraju. Dokument uznaje gęstość infrastruktury za jeden z podstawowych czynników determinujących dostępność transportową. Kluczowe znaczenie ma przy tym infrastruktura pozostająca w eksploatacji. Innym istotnym czynnikiem jest zdolność przepustowa tej infrastruktury. Autorzy opracowania podkreślają, że wszelkie decyzje, dotyczące inwestycji w poprawę dostępności transportowej, nie mogą być tylko pochodną koncepcji rozwojowych samej infrastruktury. Muszą stać się elementem spójnej polityki rozwoju regionalnego, dostrzegającej wymiary przestrzenne, ekonomiczne, osadnicze (miasta i suburbia oraz wieś, które trzeba połączyć) i cywilizacyjne. Powinny być też powiązane z koncepcją rozwoju szerszego obszaru po analizie potencjalnych więzi gospodarczych, turystycznych itd.

Strategia rozwoju kraju zarówno w perspektywie do roku 2015, 2020, jak i Dlugookresowa strategia rozwoju kraju - trzecia fala nowoczesności - Polska 2030 ujmują tematykę wzrostu dostępności transportowej w zakresie celów strategicznych. Strategia o najkrótszym horyzoncie czasowym przyjmuje za priorytet poprawę stanu infrastruktury technicznej, co ma przyczynić się do zapewnienia dostępności transportowej Polski, jej regionów, a szczególnie głównych ośrodków gospodarczych. W tym celu akcent kładziony jest na powiązanie głównych ośrodków gospodarczych siecią nowoczesnych korytarzy transportowych, zapewniających połączenia $\mathrm{z}$ siecią międzynarodową, oraz na zagwarantowanie dostępności transportowej do tych ośrodków terenom je otaczającym. Strategia o perspektywie do 2020 r. w drugim obszarze strategicznym - Konkurencyjna gospodarka, przyjmuje cel dotyczący zwiększenia efektywności transportu. Zapisy dokumentu wskazują, że jednym z ważniejszych czynników stymulujących wzrost gospodarczy i umożliwiających rozprzestrzenianie procesów rozwojowych jest nowoczesna infrastruktura transportowa, rozumiana funkcjonalnie jako warunek uruchomienia innych możliwości wykorzystania zasobów i szans rozwojowych. Szczególnie problematyczna wydaje się, wskazywana w strategii, niska dostępność transportowa niektórych obszarów Polski, a przede wszystkim miast. Izolacja miejsc, gdzie występuje koncentracja funkcji społeczno-gospodarczych oraz gdzie umiejscowione są najważniejsze władze rządowe i samorządowe, jest jedną z najważniejszych barier rozwojowych. Autorzy strategii zakładają, że po realizacji zaproponowanych w niej rozwiązań znacznie się poprawi poziom dostępności transportowej i przestanie stanowić problem o charakterze opóźnienia cywilizacyjnego i bariery rozwojowej. 
Długookresowa strategia porusza tematykę dostępności transportowej w rozdziale piątym, poświęconym celom strategicznym i kierunkom interwencji w obszarze równoważenia potencjałów rozwojowych regionów. Zawarty w tej części cel 9 bezpośrednio odnosi się do zwiększenia dostępności terytorialnej Polski, poprzez utworzenie zrównoważonego, spójnego i przyjaznego użytkownikom systemu transportowego. W tym obszarze podstawowym zadaniem jest zwiększenie dostępności transportowej, nasycenie infrastrukturą (drogi, koleje, lotniska) oraz zoptymalizowanie zarządzania transportem. Transport musi sprostać przede wszystkim wymaganiom związanym z oszczędnością czasu. Coraz krótsze czasy przejazdów, elastyczność przemieszczania się połączona z możliwością wykorzystania czasu spędzonego w podróży to priorytety polityki transportowej według długookresowej strategii. W dokumencie pojawia się też zapis nawiązujący do maksymalizacji użyteczności użytkownika transportu. Strategia zakłada dostosowanie oferty transportowej do oczekiwań różnych grup zawodowych i wiekowych ludności. Jednym z kierunków interwencji strategii jest budowa obwodnic dużych miejscowości, przebudowa pod kątem bezpieczeństwa ruchu i wdrożenie programu uspokojenia ruchu na drogach przechodzących przez miasta i małe miejscowości.

W załącznikach do Krajowej strategii rozwoju regionalnego 2010-2020: regiony, miasta, obszary wiejskie (2010) wskazano (w części poświęconej diagnozie sytuacji społeczno-gospodarczej) na słabą dostępność transportową wielu ośrodków i regionów w skali regionalnej, krajowej i europejskiej jako istotną barierę ich rozwoju. Przyczyną takiej sytuacji, według strategii, jest niedorozwój infrastruktury transportowej. Szczególne utrudnienia wynikają ze złego stanu sieci drogowej, charakteryzującej się przede wszystkim niewystarczającą liczbą połączeń niektórych części kraju, brakiem rozwoju dróg (obwodnic, niska jakość połączeń z sąsiednimi gminami) umożliwiających sprawne przejazdy w miastach i w ich otoczeniu oraz niską jakością połączeń między miastami wojewódzkimi. Zły stan dróg przyczynia się zarówno do ograniczenia płynności transportu kołowego i zwiększenia jego czasochłonności (co bezpośrednio przekłada się na ograniczenie konkurencyjności gospodarki), jak również wywiera negatywny wpływ na bezpieczeństwo ruchu drogowego. Strategia wskazuje także na niekorzystne trendy w transporcie kolejowym, które doprowadziły do ograniczenia liczby obsługiwanych połączeń pasażerskich i zmniejszyły długość całkowitą eksploatowanych w Polsce linii kolejowych. Przełożyło się to na obniżenie dostępności transportowej poszczególnych regionów kraju. Z uwagi na likwidację lub zmniejszenie częstotliwości połączeń lokalnych systematycznie zmniejsza się też dostępność transportowa wewnątrzregionalna.

Narodowe strategiczne ramy odniesienia 2007-2013 (NSRO, 2007) ${ }^{7}$ nie posiadają zapisów bezpośrednio odnoszących się do dostępności transportowej.

${ }^{7}$ Dokument został włączony do analizy pomimo upływającego okresu jego obowiązywania, ponieważ jest wyrazem prowadzonej na terytorium Polski polityki spójności Unii Europejskiej, a ustalenia na kolejny okres programowania nie przyjęly jeszcze formy dokumentu. 
W diagnozie sytuacji społeczno-gospodarczej kraju pojawiają się jedynie informacje dotyczące złego stanu infrastruktury transportowej, co skutkuje brakiem odpowiedniej jakości połączeń w transporcie międzynarodowym, jak i wewnętrznym. Wyzwania ujęte w sformułowanej strategii odnoszą się właśnie do budowy i modernizacji infrastruktury technicznej, podobnie jak cel 3 NSRO. W okresie programowania 2014-2020 należy spodziewać się intensyfikacji działań w zakresie szeroko pojętej dostępności, w związku ze wspomnianym już wcześniej nowym instrumentem - „Łącząc Europę”.

Ministerstwo Rozwoju Regionalnego i Instytut Badań Strukturalnych w raporcie dotyczącym identyfikacji i delimitacji obszarów problemowych i strategicznej interwencji w Polsce (2009) umieszczają dostępność transportową jako jedną z sześciu osi tematycznych, w oparciu o które przeprowadzono powyższe delimitacje. W raporcie wskazuje się na zagrożenie marginalizacją obszarów wywołane niskim poziomem dostępności. Podkreśla się w nim wpływ dostępności infrastruktury drogowej - zarówno w aspekcie lokalnym, jak i krajowym - na rozwój gospodarczy, warunki życia i dynamikę przemian strukturalnych w lokalnej gospodarce. Po pierwsze, warunkuje ona mobilność miejscowej siły roboczej, ułatwiając dojazdy do pracy i skracając ich długość. Po drugie, sieć transportowa jest czynnikiem komplementarnym względem innych polityk prorozwojowych. W efekcie domniemywa się, że obszary deficytowe pod względem dostępności komunikacyjnej są jednocześnie terenami, w których występują inne zagrożenia będące przedmiotem troski i zainteresowania polityki regionalnej.

Instytut Badań nad Gospodarką Rynkową w raporcie pt. Atrakcyjność inwestycyjna województw i podregionów Polski (Hildebrandt i in. 2010) uznaje dostępność transportową za jeden z najważniejszych czynników inwestycyjnych w ujęciu regionalnym. Rola dostępności transportowej w kształtowaniu atrakcyjności wiąże się z umożliwieniem i obniżeniem kosztów dostaw surowców i komponentów niezbędnych do produkcji oraz dostarczania produktów finalnych do odbiorców. W raporcie podkreśla się także istotność dostępności transportowej przy zapewnianiu warunków transportu pasażerskiego, umożliwiającego bezpośrednie spotkania z dostawcami, współpracownikami czy klientami.

Poziom dostępności transportowej bezpośrednio lub pośrednio diagnozują i kreują również liczne opracowania związane z polityką transportową kraju. Zgodnie z zapisami Diagnozy polskiego transportu (2011) dostępność transportowa, jako jeden z najważniejszych elementów systemu gospodarczego, jest warunkowana poprzez nasycenie obszaru infrastrukturą transportową oraz funkcjonujący system usług przewozowych. W dokumencie zaznaczono, że w wielu regionalnych opracowaniach analitycznych i strategicznych dostępność jest interpretowana w sposób zbyt uproszczony. Opiera się często wyłącznie na wykazaniu istnienia fizycznych połączeń transportowych w określonych kierunkach geograficznych, w świetle stanu istniejącej sieci i węzłów infrastruktury transportowej. Podkreślono jednocześnie, że takie podejście do interpretacji dostępności trans- 
portowej nie daje podstaw do kreowania zapisów polityki transportowej i priorytetyzacji inwestycji infrastrukturalnych $\mathrm{w}$ jej zakresie. Nie bierze bowiem pod uwagę istotności relacji między poszczególnymi obszarami lub miejscami. Autorzy diagnozy wyraźnie wskazują na potrzebę dokonywania systematycznej oceny dostępności transportowej zarówno terytorium Polski, jako całości, jak i poszczególnych regionów, ośrodków i węzłów zlokalizowanych na jej terytorium. Oceny nie można jednakże dokonać wyłącznie przez obliczenie wskaźników opartych na powszechnie dostępnych statystykach. Pozwoliłoby to jedynie na stworzenie uproszczonych zestawień wskaźników gęstości infrastruktury.

Celem Polityki transportowej państwa na lata 2006-2025 (2005) jest spełnienie racjonalnych oczekiwań społeczeństwa wywołanych wzrostem mobilności. Oznacza to wzmożone zapotrzebowanie na dostępność transportową, uwzględniające przy tym wieloletnie niedoinwestowanie systemu transportu oraz szereg innych czynników. Jako podstawowy cel polityki transportowej przyjmuje się zdecydowaną poprawę jakości systemu transportowego i jego rozbudowę zgodnie z zasadami zrównoważonego rozwoju. Według zapisów dokumentu, jakość systemu transportowego jest jednym z kluczowych czynników, decydujących o warunkach życia mieszkańców i o rozwoju gospodarczym kraju i regionów. Sformułowany wyżej, podstawowy cel polityki transportowej zostanie osiągnięty przez skoncentrowanie się na realizacji pierwszego z sześciu celów szczegółowych. Skupia się on na wzroście dostępności transportowej i jakości transportu jako czynnikach poprawy warunków życia i usuwania barier rozwojowych gospodarki.

Strategia rozwoju transportu do $2020 \mathrm{r}$. z perspektywa do $2030 \mathrm{r}$. (2011) traktuje dostępność transportową jako jedną z najważniejszych cech systemu gospodarczego, warunkowaną nasyceniem obszaru infrastrukturą transportową i funkcjonującym systemem usług przewozowych. Dostępność upatrywana jest też jako jedna z największych szans rozwojowych dla Polski. Głównym celem strategii jest zwiększenie dostępności transportowej, poprawa bezpieczeństwa uczestników ruchu i efektywności sektora transportowego poprzez tworzenie spójnego, zrównoważonego i przyjaznego użytkownikowi systemu transportowego w wymiarze krajowym, europejskim i globalnym. Urzeczywistnienie tego celu pozwoli na stworzenie dogodnych warunków, sprzyjających stabilnemu rozwojowi gospodarczemu kraju i jego regionów. Dla osiągnięcia celu szczególnie istotne znaczenie będzie miało wdrożenie procesów wzmacniających potencjał infrastruktury transportowej kraju oraz podnoszących jakość i dostępność usług transportowych. W strategii akcent położony został głównie na wzmocnienie powiązań i poprawę dostępności w wymiarze międzynarodowym i międzyregionalnym. Sieci o znaczeniu regionalnym i lokalnym stanowią w dużej mierze układ autonomiczny, podporządkowany tworzeniu spójności między gminami i regionalnymi ośrodkami miejskimi. W strategii wskazuje się na potrzebę wzmacniania pozycji konkurencyjnej regionów poprzez modernizację infrastruktury uzupełniającej główne 
arterie międzynarodowe i krajowe przebiegające przez ich terytorium. Podkreśla się w niej potrzebę większej kontroli powstawania brakujących ogniw i eliminacji wąskich gardeł na styku planów wojewódzkich układów sieci drogowej oraz na styku systemów transportu miejskiego i transportu dalekobieżnego.

Master plan dla transportu kolejowego w Polsce do 2030 r. (2008) ujmuje w priorytetach dotyczących rewitalizacji sektora kolejowego poprawę dostępności transportowej zarówno w przewozach pasażerskich, jak i ładunków. Zgodnie z zapisami planu, realizacja powyższego zadania ma istotny wpływ z punktu widzenia gospodarki kraju i poszczególnych regionów. Dokument przedstawia priorytet jako element operacyjny, który służyć ma realizacji celów strategicznych.

Program budowy $i$ uruchomienia przewozów kolejami dużych prędkości w Polsce (2008) uzasadnia wprowadzenie kolei o takiej charakterystyce zwiększeniem dostępności transportowej wielu regionów kraju, także dla tzw. ściany wschodniej oraz zachodniej Polski i wzmocnienie powiązań międzynarodowych. Zwiększenie dostępności transportowej ośrodków metropolitalnych oraz rejonów satelickich jest uznawane za jedną z najważniejszych szans wypływających z realizacji projektu.

Biorąc pod uwagę zakres przestrzenny rozprawy, szczególną uwagę należy poświęcić analizie dokumentów na poziomie regionalnym. W Planie zagospodarowania przestrzennego województwa łódzkiego (2010) zwiększenie dostępności województwa poprzez rozwój systemów infrastrukturalnych jest ujęte jako jeden z celów głównych. Poprawa dostępności drogowej stolicy województwa, jak i pozostałych ośrodków miejskich w powiązaniach międzyregionalnych, krajowych i europejskich to główne założenia polityki transportowej województwa, ukierunkowane na zapewnienie szybkich połączeń z innymi metropoliami i dużymi miastami w kraju. Realizację celów umożliwia program budowy autostrad i dróg ekspresowych wpisujących się w program rozwoju sieci TEN-T. Zapewnienie sprawnych i dobrych technicznie połączeń między miastami województwa, poprawa płynności ruchu i skrócenie czasu przejazdu w ruchu tranzytowym oraz zapewnienie dobrej przejezdności przez miasta to następne cele zmierzające do zwiększenia dostępności wewnętrznej województwa. Priorytetem jest również eliminacja uciążliwości ruchu tranzytowego i ciężkiego z centrów miast i miejscowości o gęstej zabudowie oraz poprawa bezpieczeństwa ruchu. W zakresie transportu kolejowego, poprawy dostępności miast, jak i całego regionu, autorzy planu upatrują $\mathrm{w}$ realizacji inwestycji kolejowych na poziomie realizowanego obecnie programu budowy kolei dużych prędkości. Konieczne jest włączenie kolei do wewnętrznej obsługi komunikacyjnej aglomeracji i stworzenie spójnego systemu kolei aglomeracyjnej, regionalnej i międzyregionalnej, zintegrowanych z koleją szybką. Działania w tym aspekcie winny zmierzać również do segregacji ruchu na liniach kolejowych oraz zwiększenia udziału kolei w przewozach pasażerskich i towarowych w myśl zasad zrównoważonego rozwoju. Plan jako pierwszy dokument wspomina o transporcie tramwajowym jako środku trans- 
portu przyjaznemu środowisku, który należy traktować priorytetowo w polityce transportowej województwa, zmierzającej do zwiększenia jego dostępności transportowej. Trzeba jednocześnie zwrócić uwagę na znacznie ograniczony zasięg oddziaływania sieci tramwajowej w województwie łódzkim. Dlatego też nawet skuteczna polityka prowadzona wobec tego środka transportu może przyczynić się do zwiększenia dostępności zaledwie kilku miast województwa.

Strategia rozwoju województwa łódzkiego 2020 ujmuje zagadnienia transportowe m.in. w części poświęconej stanowi i uwarunkowaniom rozwoju regionu. W ramach zagadnień omawiających przestrzeń i powiązania funkcjonalno-przestrzenne dostępność transportowa nie pojawia się w sposób bezpośredni. Przedstawione są jedynie dane mówiące o położeniu regionu w krajowej sieci transportowej oraz porównanie z pozostałymi 15 województwami. Zagadnienie dostępności pojawia się natomiast jako jedno z głównych wyzwań rozwojowych. Tematyka dostępności infrastruktury transportowej została ujęta w 7 celu operacyjnym strategii. Dostępność do infrastruktury warunkuje rozwój ekonomiczny i społeczny, stanowi o atrakcyjności inwestycyjnej, a także zapewnia wysoką jakość obsługi mieszkańców. Powiązania z międzynarodowymi sieciami transportowymi umożliwiają dostęp do rynków zewnętrznych, transfer innowacji oraz napływ wysoko wykwalifikowanych specjalistów. W powiązaniach wewnętrznych wysokiej jakości infrastruktura transportowa zapewnia spójność przestrzenną regionu. Strategiczny kierunek działania 7.1.1 zakłada rozwój drogowych, kolejowych, lotniczych powiązań zewnętrznych i wewnętrznych o znaczeniu strategicznym, m.in. poprzez wsparcie budowy podłączeń do autostrad i dróg ekspresowych, rozbudowy i przebudowy dróg ogólnodostępnych czy budowy obwodnic.

Celem szczegółowym osi priorytetowej I - Infrastruktura transportowa $w$ regionalnym programie operacyjnym województwa łódzkiego na lata 2007-2013 jest poprawa dostępności transportowej regionu. Sprawny, efektywny oraz bezpieczny system transportu, zgodny z normami unijnymi w zakresie ochrony środowiska, zapewniający połączenia komunikacyjne województwa nie tylko wewnętrzne, ale również z innymi regionami, jest niezbędny do dynamicznego rozwoju społeczno-gospodarczego. Dobrze rozwinięta dostępność transportowa zwiększa atrakcyjność inwestycyjną województwa oraz mobilność mieszkańców, skracając czas przejazdu. Pozytywnie wpływa również na bezpieczeństwo uczestników ruchu, zapewniając wszystkim mieszkańcom możliwości rozwojowe.

Regionalna strategia innowacji dla województwa łódzkiego - LORIS 2030 (2011) podkreśla znaczenie dostępności transportowej, m.in. przedstawiając ją jako wyraźny atut w diagnozie sytuacji regionu. Dzięki nakładom infrastrukturalnym region ma szansę zwiększyć swą dostępność zewnętrzną i wewnętrzną, co wpłynie m.in. na pobudzenie mobilności społeczeństwa, a słabiej rozwinięte podregiony nie będą zwiększać dystansu do tych najlepiej rozwiniętych. Dobre warunki komunikacyjne będą stanowić poważną zachętę dla inwestorów. 
W świetle poddanych analizie opracowań uwidacznia się sygnalizowane w przeglądzie definicyjnym intuicyjne stosowanie pojęcia dostępności transportowej. Autorzy, używając różnych określeń, chcą (jak wynika z treści) przedstawić w większości przypadków to samo zagadnienie. Może to sprawiać wrażenie pewnej niespójności pomiędzy opracowaniami na różnych szczeblach i odnoszących się do różnych branż. Ponadto odbiorca, nie będąc wtajemniczonym w tematykę dostępności transportowej, może uznać, że poszczególne prace dotyczą czego innego, choć de facto sprowadzają się do tego jednego celu. Należy również podkreślić, iż analizowane opracowania bardzo lakonicznie (o ile w ogóle) odnoszą się do dostępności transportowej małych i średnich miast. Duża uwaga przywiązywana jest do ośrodków dużych i obszarów metropolitarnych jako obszarów dużego potencjału społeczno-gospodarczego. Mniejsze ogniwa układu osadniczego regionu wydają się zbyt mało atrakcyjne do badania lub też ich dostępność transportowa jest diagnozowana nieodpowiednio. Dokładna analiza zapisów w dokumentach odnoszących się do dostępności transportowych pozwala zauważyć pewną asymetrię pomiędzy transportem samochodowym i kolejowym na korzyść tego pierwszego. Odzwierciedla to zapewne występującą również w rzeczywistości większą gęstość sieci drogowej i większy udział transportu samochodowego w przewozach ludzi i ładunków. Niemniej jednak dążenie do zrównoważenia transportu i strategiczne inwestycje w transporcie kolejowym wydają się na tyle istotne, aby być obdarzone tą samą atencją, co transport samochodowy. Analiza opracowań strategicznych wykazuje, że jedynym efektywnym sposobem podniesienia poziomu dostępności transportowej są inwestycje w infrastrukturę transportową. Nie pojawiają się (poza zasygnalizowaniem) rozwiązania dotyczące nowoczesnych systemów transportowych i możliwości płynących z ich wdrożenia. 



\section{DOSTĘPNOŚĆ TRANSPORTOWA MIAST W ŚWIETLE INFRASTRUKTURY TRANSPORTOWEJ}

\subsection{Infrastruktura drogowa i kolejowa regionu lódzkiego w krajowej sieci transportowej}

W Diagnozie polskiego transportu (2011) zwrócono uwagę, że z punktu widzenia wpływu na rozwój gospodarczy kraju infrastrukturę transportową należy oceniać pod względem jej dostępności oraz stanu technicznego. Jak już wspomniano, o poziomie dostępności decyduje m.in. gęstość sieci, jej struktura i układ, które są możliwe do określenia za pomocą różnorodnych wskaźników o charakterze geograficznym, demograficznym i ekonomicznym.

Dostępność transportowa polskich regionów (w ujęciu potencjałowym) została szczegółowo zbadana m.in. w projektach ESPON dla roku 2001 i pięć lat później. Obecnie zapewne poziom dostępności uległ pewnej poprawie za sprawą polskich inwestycji w infrastrukturę transportową. W analizach na szczeblu europejskim wyraźnie akcentowany jest element oddalenia od „rdzenia Europy”, które wpływa bezpośrednio na regionalną dostępność w Polsce. Województwa znajdujące się blisko granicy zachodniej państwa są wyraźnie lepiej dostępne niżeli te zlokalizowane w centralnej i wschodniej Polsce. Zróżnicowanie potencjałowej dostępności drogowej i kolejowej polskich województw do „rdzenia” jest podobne dla obydwu gałęzi transportu. Największymi problemami z dostępnością obarczone są regiony leżące na wschodzie i częściowo na północy kraju. Natomiast sąsiedztwo z granicą z Niemcami i Republiką Czeską charakteryzuje się najwyższym poziomem dostępności. Diagnoza polskiego transportu (2011) podaje, że dostępność przodujących pod tym względem regionów Polski nie osiąga nawet średniej dla wszystkich krajów członkowskich. Województwa o deficycie dostępności nie przekraczają poziomu $60 \%$ tejże średniej.

Wysoki poziom dostępności transportowej przekłada się bezpośrednio na atrakcyjność inwestycyjną danego obszaru. Potwierdzają to wyniki analiz Instytutu Badań nad Gospodarką Rynkową zawarte w raporcie Atrakcyjność inwestycyjna województw i podregionów Polski (Hildebrandt i in. 2010). Biorąc pod 
uwagę położenie względem zachodniej granicy Polski, usytuowanie województwa względem Warszawy oraz położenie względem międzynarodowych portów lotniczych i morskich, określono atrakcyjność poszczególnych województw Polski. Raport podkreśla wysoką atrakcyjność regionu łódzkiego dla rozwoju przemysłu, wynikającą z ponadprzeciętnej dostępności transportowej. Wysoki poziom dostępności transportowej jest również wskazany jako mocna strona województwa łódzkiego - obszaru rozwoju działalności usługowej. Szczególnie podkreślana jest tutaj rola węzła transportowego rangi ponadregionalnej z dostępem lotniska międzynarodowego oraz korzystne położenie względem Warszawy. Te same elementy upatrywane są w powyższej analizie jako atuty województwa łódzkiego - ośrodka rozwoju działalności związanych z wysoką technologią.

Województwo łódzkie położone jest w środku kraju (geograficzny środek Polski znajduje się $23 \mathrm{~km}$ na północny wschód od stolicy województwa). Takie uwarunkowanie jest niezwykle korzystne dla dostępności transportowej. Większość najważniejszych ośrodków miejskich w Polsce, w tym 9 miast wojewódzkich, znajduje się w ekwidystancie 200 km (odległość fizyczna) od stolicy województwa łódzkiego.

Z wyznaczonych (na II Paneuropejskiej Konferencji Transportowej na Krecie w marcu 1994, a uzupełnionych na III Paneuropejskiej Konferencji Transportowej w Helsinkach w trzy lata później) dziesięciu transeuropejskich korytarzy transportowych, cztery przechodzą przez obszar Polski, a dwa z nich przebiegają przez obszar województwa łódzkiego. Pierwszy to korytarz nr II o przebiegu równoleżnikowym łączącym Berlin, Warszawę, Mińsk i Moskwę. Korytarz obejmuje autostradę A2 oraz magistralę kolejową E20. Drugi z korytarzy (nr VI) biegnie z północy na południe, rozpoczynając się w Gdańsku, a następnie prowadzi przez Łódź/Warszawę do Žyliny (w wersji zachodniej przez Ostrawę do Brna). W granicach województwa łódzkiego korytarz tworzy autostrada A1 wraz z drogą ekspresową S8 (Piotrków Trybunalski-Warszawa), a w zakresie infrastruktury kolejowej - magistrala węglowa Śląsk-Porty oraz Centralna Magistrala Kolejowa. Priorytetowe inwestycje w zakresie infrastruktury (objętej wyżej wymienionymi korytarzami) są skierowane głównie na linie kolejowe na terenie województwa łódzkiego. Kompetencje związane z kreowaniem polityki dotyczącej transportu ${ }^{1}$ i sieci transeuropejskich Unia Europejska współdzieli z państwami członkowskimi (art. 4 TFUE). Wynika to z konieczności zapewnienia swobodnego przepływu towarów, osób, usług i kapitału w ramach pozbawionego wewnętrznych granic rynku Unii Europejskiej (art. 3, pkt 2 Traktatu o Unii Europej-

\footnotetext{
${ }^{1}$ Wspólna polityka transportowa krajów członkowskich Unii Europejskiej koncentruje się na ustaleniu reguł transportu międzynarodowego w krajach członkowskich, warunków tranzytu przez terytoria państw członkowskich oraz reguł dostępu przewoźników zagranicznych do transportu krajowego każdego z krajów członkowskich (art. 91, pkt 1 TFUE). Unia Europejska rezerwuje sobie również prawo do wspierania działań mających na celu zwiększenie bezpieczeństwa transportu.
} 
skiej, dalej: TUE, art. 26, pkt 1-2 TFUE) oraz dążenia do spójności gospodarczej, społecznej i terytorialnej, a ponadto harmonijnego rozwoju całego obszaru Unii Europejskiej (art. 3, pkt 3 TUE, art. 174 TFUE). W decyzji Parlamentu Europejskiego i Rady z 7 lipca 2010 r. (661/2010/UE) zdefiniowany został plan modernizacji i integracji infrastruktury sieci transportu lądowego, morskiego i lotniczego, wskazujący wytyczne dla projektów rozwoju TEN-T. Tworzone sieci muszą spełniać szereg założeń, m.in.: przyczyniać się do wzmocnienia spójności gospodarczej i społecznej, oferować użytkownikom wysokiej jakości infrastrukturę transportową oraz przyczyniać się do wzmocnienia spójności terytorialnej, łącząc główne regiony i największe ośrodki miejskie Unii Europejskiej (art. 2, pkt 2 661/2010/UE). W załącznikach do powyższej decyzji Parlamentu Europejskiego i Rady określono projekt przebiegu TEN-T dla wszystkich krajów członkowskich. Zgodnie z załącznikiem w postaci mapy (załącznik 2.20 661/2010/ UE), w województwie łódzkim do TEN-T włączono następujące elementy sieci drogowej: autostrady A1 i A2 oraz drogę ekspresową S8 w tzw. wariancie bełchatowskim. Jeżeli chodzi o sieć kolejową (załącznik 3.18 661/2010/UE), do TEN-T włączone zostaną następujące linie: 1 (Warszawa-Skierniewice-Koluszki-Częstochowa-Katowice), 3 (Słubice-Poznań-Kutno-Lowicz-SochaczewWarszawa), 11 (Łowicz-Skierniewice), 12 (Skierniewice-Pilawa-Luków-Biała Podlaska-Terespol) oraz 131 (Tczew-Bydgoszcz-Inowrocław-Zduńska Wola Karsznice-Tarnowskie Góry). W załącznikach do wniosku Komisji Europejskiej (COM/2012/665) wskazano wstępnie zaakceptowane projekty związane z rozwojem bazowej sieci transportowej. Dla województwa łódzkiego kluczowe znaczenie ma realizacja inwestycji w dwóch korytarzach sieci bazowej: korytarzu Bałtyk-Adriatyk (modernizacja linii kolejowej z Gdyni do Katowic, przebiegającej przez zachodnią część województwa - doprowadzenie do szybkości $160 \mathrm{~km} / \mathrm{h}$ dla ruchu pasażerskiego, docelowo $250 \mathrm{~km} / \mathrm{h}, \mathrm{i} 120 \mathrm{~km} / \mathrm{h}$ dla ruchu towarowego) oraz korytarzu Warszawa-Berlin-Amsterdam/Rotterdam-Felixstowe-Midlands (modernizacja istniejącej linii kolejowej od granicy polsko-białoruskiej, przez Warszawę, Poznań do granicy z Niemcami - doprowadzenie do szybkości $160 \mathrm{~km} / \mathrm{h}$ dla ruchu pasażerskiego, docelowo $250 \mathrm{~km} / \mathrm{h}$, i $120 \mathrm{~km} / \mathrm{h}$ dla ruchu towarowego, a także wykonanie prac studyjnych dotyczących kolei dużych prędkości). 6 lutego 2012 r. Komisja Europejska sporządziła ostateczną wersję wniosku o uchwalenie nowego rozporządzenia Parlamentu Europejskiego i Rady w sprawie unijnych wytycznych dotyczących rozwoju transeuropejskiej sieci transportowej (COM/2011/650), które miało zastąpić omówione wyżej rozporządzenie z 7 lipca 2010 r. (661/2010/UE). Celem nowych wytycznych było ustanowienie kompletnej (obejmującej wszystkie państwa członkowskie oraz ich regiony) i zintegrowanej sieci transportowej. W analizowanym projekcie rozporządzenia Parlamentu Europejskiego i Rady wskazany został podział sieci TEN-T na kompleksową i bazową. Sieć kompleksowa zawiera wszystkie istniejące, modernizowane i planowane elementy sieci TEN-T. Sieć bazowa natomiast składać się będzie z tych elementów 
sieci kompleksowej, które mają znaczenie strategiczne dla realizacji celów funkcjonowania TEN-T. W województwie łódzkim do sieci bazowej TEN-T zaliczono autostrady A1 i A2 oraz drogę ekspresową S8 w tzw. wariancie łódzkim, na odcinku od granicy województwa do Rzgowa. Do sieci bazowej zaliczono również linie kolejowe transportu towarowego: linię 1 (wyłącznie na odcinku WarszawaSkierniewice-Koluszki), linię 4 (Warszawa-Mszczonów-Opoczno-Zawiercie), linię 14 (wyłącznie na odcinku Koluszki-Łódź-Zduńska Wola Karsznice) oraz linię 131 (Tczew-Bydgoszcz-Inowrocław-Zduńska Wola Karsznice-Tarnowskie Góry). Z linii kolejowych transportu pasażerskiego w bazowej sieci TEN-T znalazły się: projektowana linia kolei dużych prędkości „Y” (Warszawa-MszczonówŁódź-Kalisz-Poznań, Wrocław), wspomniana wyżej linia 4 (Warszawa-Mszczonów-Opoczno-Zawiercie), linia 14 (wyłącznie na odcinku Łódź-Koluszki) oraz linia 25 (wyłącznie na odcinku Łódź-Opoczno). W sieci kompleksowej TEN-T, w województwie łódzkim uwzględniono dodatkowo odcinki dróg ekspresowych: S8 z Piotrkowa Trybunalskiego w kierunku Warszawy, S12 (wyłącznie na odcinku z Piotrkowa Trybunalskiego w kierunku Radomia) i S74. Linię kolejową 25 (Łódź-Opoczno-Skarżysko Kamienna-Tarnobrzeg-Mielec-Dębica) zakwalifikowano do sieci kompleksowej TEN-T kolejowego transportu towarowego. Łódź wskazano jako lokalizację terminalu drogowo-kolejowego w ramach bazowej sieci TEN-T, zaś Stryków - sieci kompleksowej (COM/2011/650, TENtec Public Portal) (Napierała i in. 2013).

W sieci dróg międzynarodowych jest zlokalizowanych 17 spośród 44 miast województwa łódzkiego. Połączenia multimodalne (sieć drogowa i kolejowa) na poziomie międzynarodowym ma jedynie Kutno i Łowicz. Region łódzki ma specyficzną sytuację w układzie krajowych linii kolejowych. Historyczne uwarunkowania rozwoju sieci kolejowej spowodowały, że najważniejsze linie kolejowe o znaczeniu krajowym (i międzynarodowym) biegną w peryferyjnych obszarach województwa, omijając stolicę regionu. Dotyczy to linii transeuropejskich: E20 Warszawa-Kutno-Poznań, Centralnej Magistrali Kolejowej, która przebiega tranzytem przez województwo, łącząc Warszawę ze Śląskiem i Zagłębiem oraz Krakowem (żadne z miast województwa nie leży na jej przebiegu - najbliżej położonym linii miastem jest Opoczno). Podobny charakter ma magistrala węglowa Herby Nowe-Zduńska Wola (Karsznice)-Inowrocław-Gdynia ze stacją towarowo-rozrządową w Karsznicach (Zduńska Wola). Tym samym wymienione linie nie mają znaczenia dla połączeń województwa w relacjach międzyregionalnych czy międzynarodowych. Dla krajowych powiązań województwa łódzkiego duże znaczenie ma stara linia kolei warszawsko-wiedeńskiej i kolej kaliska oraz biegnąca z Łodzi linia kolejowa do Gdańska i Gdyni (Taylor 2007).

Ponad jedna trzecia miast województwa leży z dala od linii kolejowych. Łódź jest szczególnie poszkodowana pod względem położenia w sieci kolejowej, co wynika z jej późnego rozwoju gospodarczego i krótkiego stażu administracyjnego. Współczynnik wydłużenia linii kolejowych w stosunku do powiązań prostoli- 
niowych z Łodzi do innych miast wojewódzkich wynosi na ogół ponad 125. Łódź jest ważnym węzłem kolejowym na kierunku Warszawa-Wrocław i Poznań-Lublin. Następnym kolejowym węzłem są Koluszki, poprzez które Łódź połączona jest z Warszawą, Lublinem, Katowicami i Krakowem. Mniejszymi węzłami kolejowymi są: Skierniewice, Łowicz, Tomaszów Mazowiecki (Diagnoza województwa tódzkiego 2005).

Obecna sieć linii kolejowych zapewnia jedynie podstawową obsługę regionu. Brakuje natomiast obsługi województwa, a właściwie Łodzi i jej aglomeracji, poprzez trasy przystosowane do kursowania pociągów o podwyższonej prędkości. Są to jedynie krótkie odcinki, takie jak Koluszki-Skierniewice, KoluszkiPiotrków Trybunalski, Kutno-północna granica województwa, które mogą prowadzić ruch pociągów z prędkością przekraczającą $120 \mathrm{~km} / \mathrm{h}$. Kolej w ramach restrukturyzacji, zmierzając do obniżki kosztów i poprawy rentowności, likwiduje obsługę szeregu linii, głównie w północnej i zachodniej Polsce. W tym przypadku słabo rozwinięta sieć kolejowa w województwie łódzkim pozostaje w zasadzie niezmieniona i traktowana jest jako sieć linii magistralnych i pierwszorzędnych.

W sieci drogowej jedynie dwa ośrodki leżą na przecięciu szlaków o przebiegu południkowym i równoleżnikowym. Jednym z nich jest Piotrków Trybunalski, leżący na skrzyżowaniu drogi krajowej $\mathrm{nr} 1$ oraz 8/S8. Drugim ośrodkiem jest Stryków, w którym krzyżują się autostrady A1 i A2. Najwięcej miast w województwie łódzkim łączy droga międzynarodowa E75 (9 jednostek) oraz E67 (6 jednostek).

Województwo łódzkie, poprzez sieć dróg krajowych, ma połączenia z podstawowymi ośrodkami gospodarczymi i miejskimi Polski (rycina 2.1): droga nr 14 łączy stolicę województwa z Wrocławiem, nr 72 z Poznaniem i Warszawą, droga 74 z Kielcami, nr 12 z Kaliszem i Lublinem.

Ukształtowany system powiązań drogowych powoduje, że stopień wydłużenia dróg jest stosunkowo wysoki, szczególnie do miast położonych w północno-zachodniej Polsce oraz do Krakowa i Kielc. Warto podkreślić, iż w sieci dróg krajowych znajdują się wszystkie miasta województwa łódzkiego z wyjątkiem Szadku, Żychlina, Koluszek, Zelowa, Białej Rawskiej i Drzewicy. Najkorzystniejsze położenie wśród miast województwa łódzkiego w krajowej sieci drogowej mają ośrodki będące głównymi węzłami w tej sieci: Łódź (skrzyżowanie dróg: nr 1, nr 14, nr 72, nr 91), Piotrków Trybunalski (nr 1, A1, 8, S8, 12, 91), Stryków (A1 i A2) oraz Sieradz (nr 12, nr 14, nr 83). Jako bardzo ważne skrzyżowania dróg krajowych wymienić należy Krośniewice (drogi nr 91 oraz nr 92), poza tym Sulejów (drogi nr 12 oraz nr 74), Wieluń (nr 8, nr 43, nr 45), Kutno (nr 92, nr 60), Łowicz (nr 92, nr 14, nr 70a) oraz Radomsko (nr 1, nr 42, nr 91).

Województwo łódzkie, pomimo że leży w środkowej Polsce i ma jedną z największych aglomeracji, jaką jest aglomeracja łódzka, posiada bardzo niski odsetek linii kolejowych w kraju. $\mathrm{Na} 100 \mathrm{~km}^{2}$ przypada tu zaledwie 5,8 $\mathrm{km}$ linii normalnotorowych (rycina 2.2), przy 6,4 km średnio w kraju. Długość tych linii 


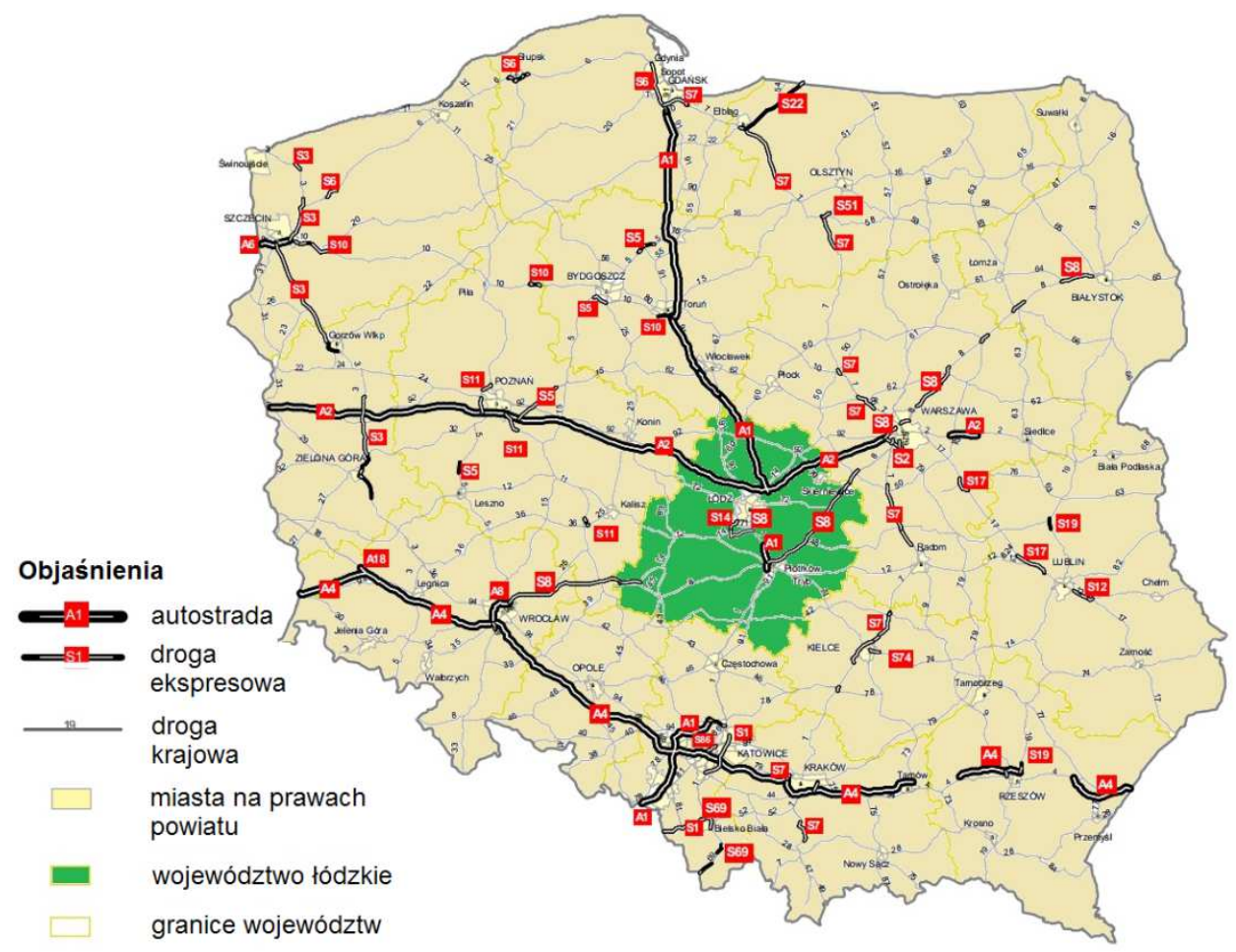

Rycina 2.1. Sieć dróg krajowych (stan na 23.05.2014)

Źródło: opracowanie własne na podstawie danych udostępnionych przez GDDKiA

wynosi $1055 \mathrm{~km}^{2}$. Na terenie województwa łódzkiego są one zarządzane przez zakłady linii kolejowych: Łódź, Bydgoszcz, Warszawa, Skarżysko-Kamienna, Częstochowa, Tarnowskie Góry oraz Ostrów Wielkopolski.

Kształt sieci połączeń kolejowych w Polsce jest w główniej mierze pozostałością po okresie zaborów, choć likwidacja coraz dłuższych odcinków linii lokalnych zmienia tę sytuację. Najwięcej linii przebiega przez uprzemysłowione rejony Śląska oraz Wielkopolskę i Pomorze Zachodnie. Najwięcej jest też w tych regionach połączeń kolejowych uzupełniających podstawową sieć. Można przyjąć, że lepsza infrastruktura tych ziem odziedziczona po zaborze pruskim wpłynęła na szybszy ich rozwój. $Z$ drugiej strony rozwój i tradycyjna gospodarność tych regionów miała wpływ na rozbudowę infrastruktury. Najmniejsza jest gęstość sieci kolejowej w rolniczych, oddalonych od większych ośrodków, rejonach pogranicza Mazowsza i Mazur. Niewiele linii przecina także obszary przygraniczne we

2 Bank Danych Lokalnych, http://www.stat.gov.pl/bdl/app/strona.html?p_name=indeks (19.09.2013). 


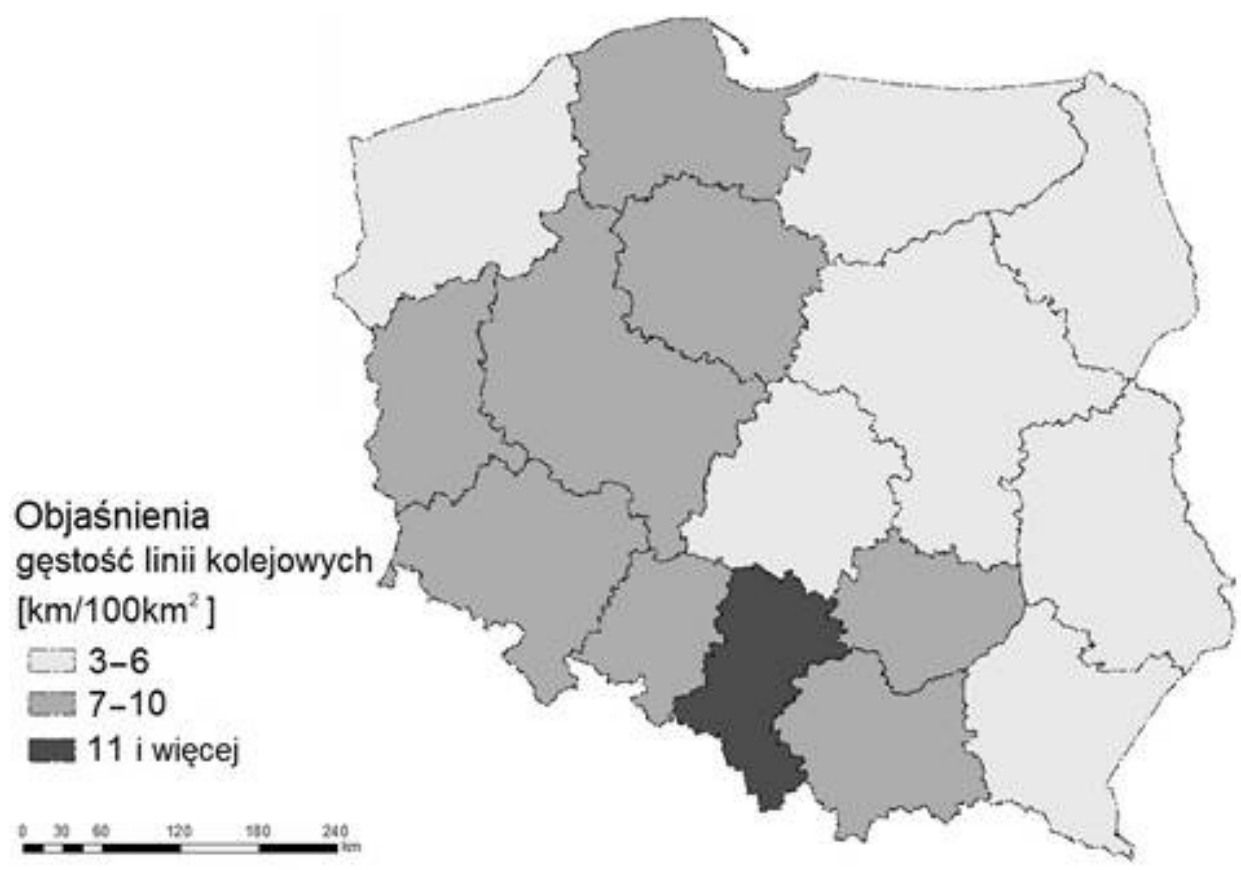

Rycina 2.2. Gęstość linii kolejowych w Polsce według województw w 2012 r.

Źródło: opracowanie własne na podstawie BDL GUS (nieczytelne), nie zgadza się liczba klas

wschodniej części kraju, choć z racji korzystniejszego układu połączeń są one często łatwiej dostępne niż północna Polska. Dane te są jedynie ilustracją statystyczną, gdyż o rzeczywistej dostępności pociągów decyduje przede wszystkim rozkład jazdy i rozmieszczenie stacji, ładowni i przystanków osobowych (Majewski 2002).

Długość dróg gminnych (o nawierzchni twardej ulepszonej) w województwie łódzkim wynosi $7468,4 \mathrm{~km}$. Daje to gęstość na poziomie $41 \mathrm{~km} / 100 \mathrm{~km}^{2}$, która sytuuje województwo łódzkie w czołówce regionów (większą gęstość ma jedynie województwo śląskie - 96,5 i małopolskie $-83 \mathrm{~km} / 100 \mathrm{~km}^{2}$ ). Wartości dla łódzkiego przekraczają również średnią dla całej Polski $(31,4)^{3}$.

Podobnie prezentuje się charakterystyka województwa łódzkiego przez pryzmat sieci dróg powiatowych ${ }^{4}$. Średnia gęstość dla regionu to $44,5 \mathrm{~km} / 100 \mathrm{~km}^{2}$. Lepiej wyposażone pod tym względem jest jedynie województwo śląskie $\left(49 \mathrm{~km} / 100 \mathrm{~km}^{2}\right)$ oraz świętokrzyskie $\left(46 \mathrm{~km} / 100 \mathrm{~km}^{2}\right)$. Łódzkie przekracza tym samym średnią wartość dla kraju na poziomie $36 \mathrm{~km} / 100$ km².

${ }^{3}$ Ibid.

${ }^{4}$ Ibid. 
Długość dróg wojewódzkich w regionie łódzkim wynosi 1152,4 km, z czego $123,2 \mathrm{~km}$ to odcinki miejskie. Wszystkie drogi wojewódzkie są zarządzane przez Zarząd Dróg Wojewódzkich w Łodzi. Jedynie odcinki przechodzące przez miasta na prawach powiatu są administrowane przez te miasta (Łódź, Piotrków Trybunalski, Skierniewice). Gęstość sieci dróg wojewódzkich ${ }^{5}$ wynosi $6,33 \mathrm{~km} /$ $100 \mathrm{~km}^{2}$. Porównując długość sieci dróg do pozostałych województw, województwo łódzkie wyprzedza jedynie województwa świętokrzyskie oraz opolskie. Największa gęstość sieci dróg wojewódzkich występuje w województwie dolnośląskim i wynosi $12,07 \mathrm{~km} / 100 \mathrm{~km}^{2}$. Wszystkie łódzkie drogi wojewódzkie posiadają ulepszoną nawierzchnię.

W przypadku dróg o ograniczonej dostępności sytuacja województwa łódzkiego kształtuje się znacznie gorzej (rycina 2.3).

Łączna gęstość dróg ekspresowych i autostrad w regionie wynosi $0,42 \mathrm{~km} /$ $100 \mathrm{~km}^{2}$, co plasuje województwo łódzkie poniżej średniej dla Polski $(0,64)$.

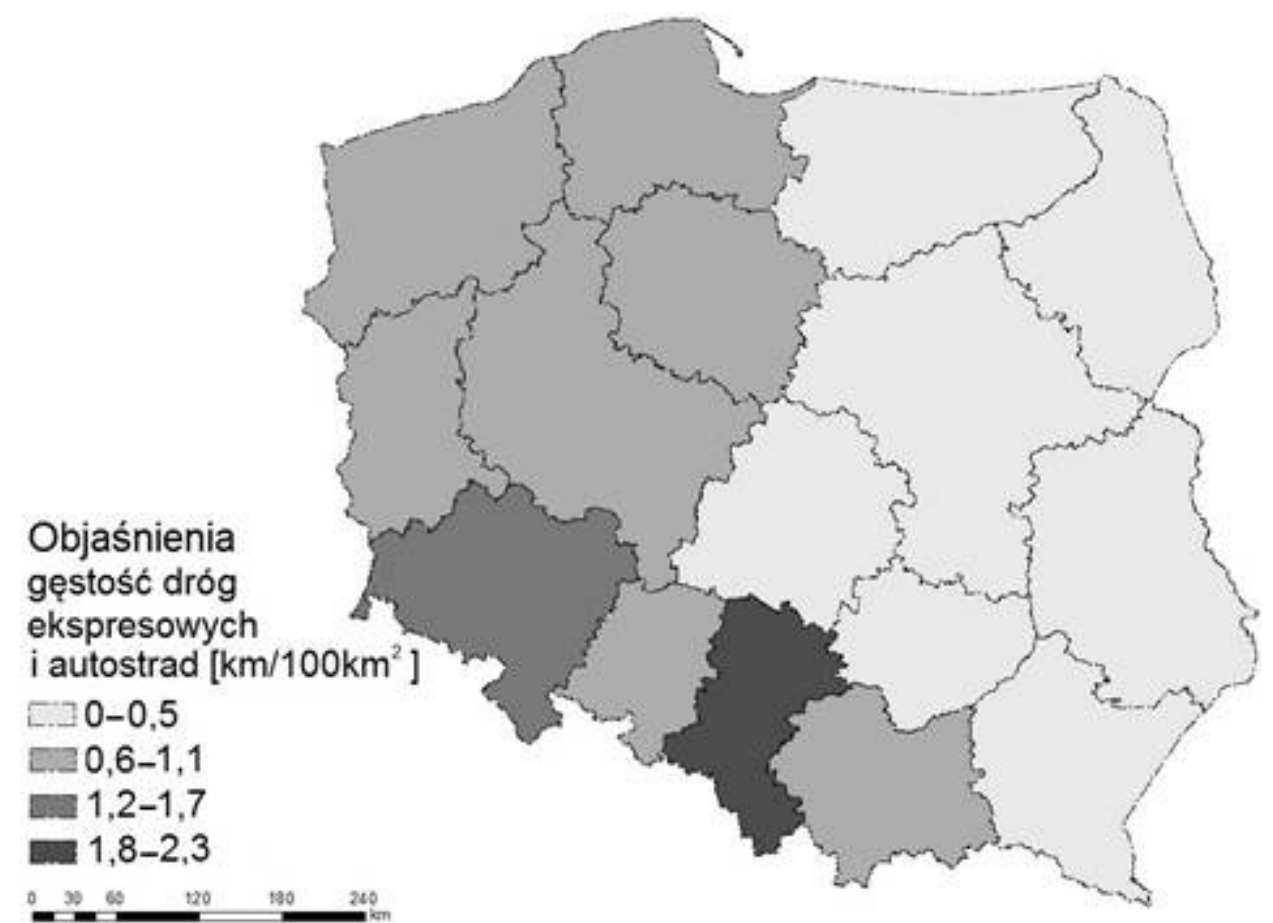

Rycina 2.3. Gęstość dróg ekspresowych i autostrad w Polsce według województw w 2012 r.

Źródło: opracowanie własne na podstawie BDL GUS

${ }^{5}$ Wydział Dróg, Zarząd Dróg Wojewódzkich w Łodzi. 
Województwo łódzkie zajmuje 11 miejsce wśród wszystkich regionów kraju ${ }^{6}$. Trzeba jednakże zaznaczyć, że wskazana gęstość w województwie łódzkim będzie systematycznie rosnąć w wyniku intensywnych inwestycji mających na celu eliminację zapóźnień historycznych i aktualne strategie transportowe.

Znacznie bardziej pozytywnie kształtuje się sytuacja województwa łódzkiego, gdy analizie zostanie poddane drogowe wyposażenie infrastrukturalne poza miastami (rycina 2.4). Ten wskaźnik jest szczególnie ważny w przypadku niniejszej pracy, gdyż badane są relacje pomiędzy miastami, a nie w nich samych. Rzecz jasna, że jeśli analizowana jest podróż pomiędzy dwoma miastami, która przebiega dodatkowo przez inne jednostki, to w takiej sytuacji wyposażenie miast ma oczywiście znaczenie. W województwie łódzkim gęstość dróg zamiejskich o twardej nawierzchni ulepszonej wynosi $82,3 \mathrm{~km} / 100 \mathrm{~km}^{2}$, co przekracza poziom średni dla Polski $(66,5)$. Wśród wszystkich regionów kraju, łódzkie plasuje się na 4 miejscu, za województwem małopolskim $(113,6)$, śląskim $(90,4)$ i świętokrzyskim $(84,8)$.
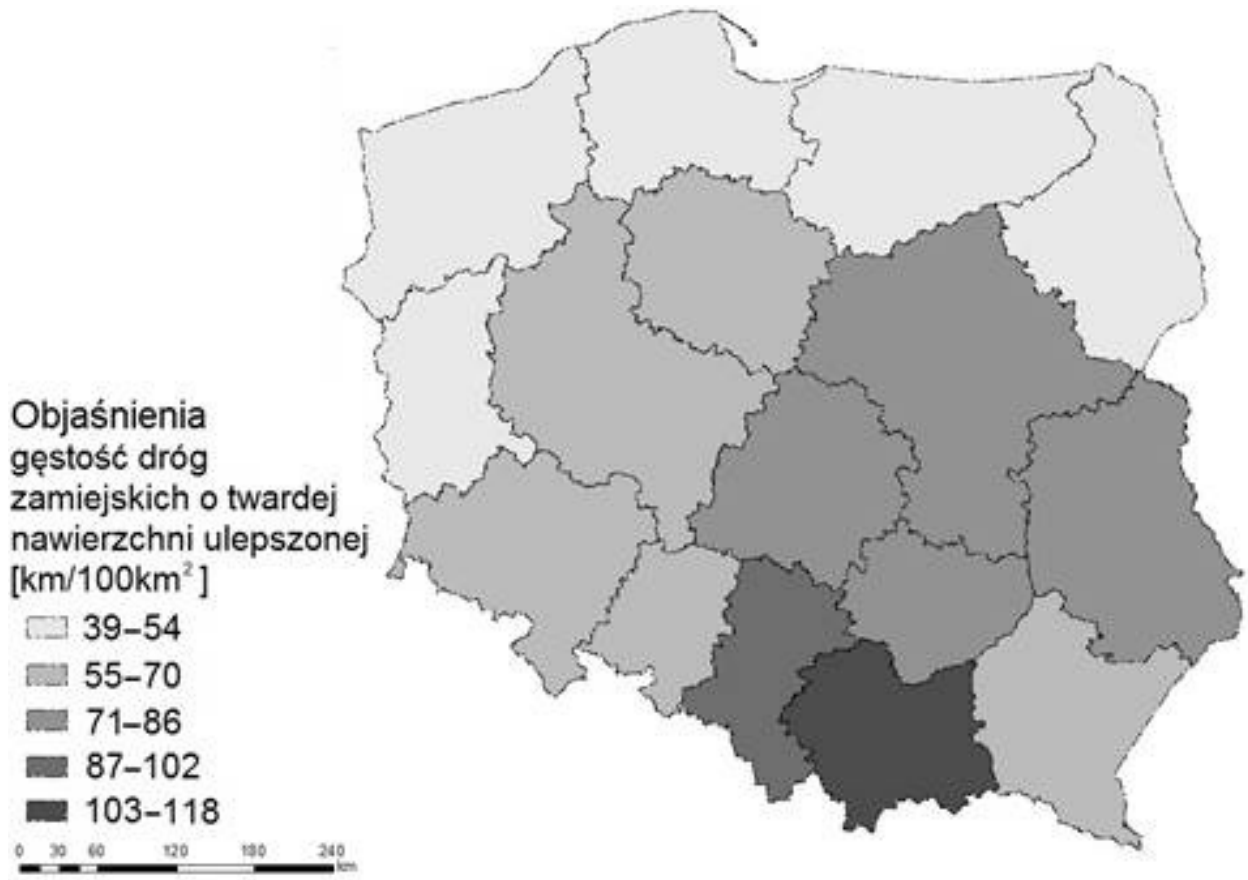

Rycina 2.4. Gęstość dróg zamiejskich o twardej nawierzchni ulepszonej w Polsce według województw w 2012 r.

Źródło: opracowanie własne na podstawie BDL GUS

${ }^{6}$ Bank Danych Lokalnych, http://www.stat.gov.pl/bdl/app/strona.html?p_name=indeks (19.09.2013). 
Bardzo ważnym elementem warunkującym użytkowanie sieci drogowej jest również poziom motoryzacji. Zmiany w poziomie motoryzacji pośrednio wpływają na stan jakościowy infrastruktury transportu oraz czas przewozu osób i towarów coraz bardziej zatłoczonymi drogami. Tym samym poziom motoryzacji w poszczególnych województwach (rycina 2.5 ) determinuje potrzeby inwestycyjne regionów. Pod względem poziomu motoryzacji, wyrażonego liczbą pojazdów (na 1 tys. mieszkańców), województwo łódzkie plasuje się na 4 miejscu wśród 16 regionów Polski. Bardziej obciążoną infrastrukturę drogową ma województwo wielkopolskie (713 pojazdów), mazowieckie (700 pojazdów) oraz opolskie (655 pojazdów). Łódzkie, charakteryzujące się liczbą pojazdów na poziomie 650, przekracza również średni poziom liczby pojazdów dla Polski (628 pojazdów)7

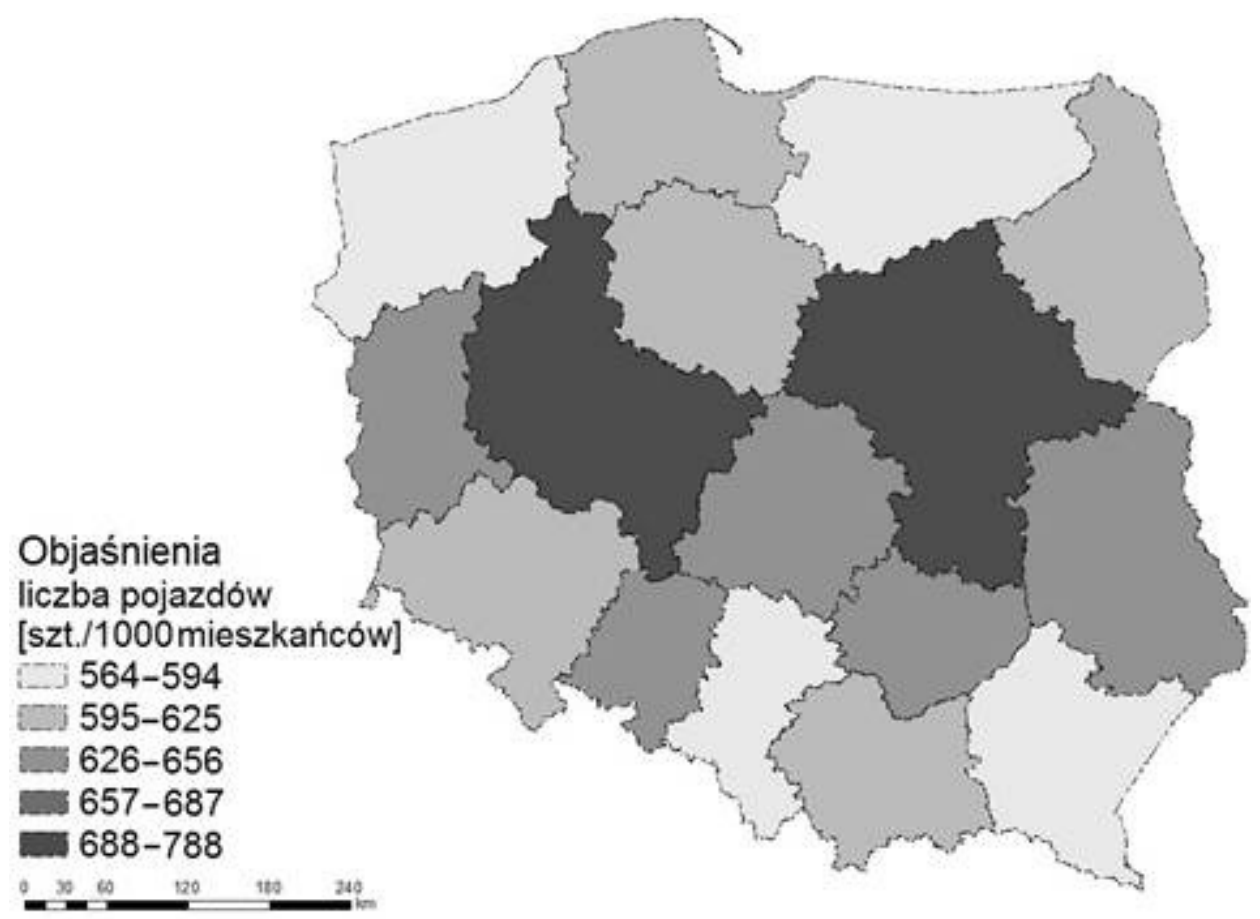

Rycina 2.5. Liczba pojazdów w Polsce według województw w 2012 r.

Źródło: opracowanie własne na podstawie BDL GUS

W celu uzupełnienia analizy porównawczej regionów porównano również wydatki na transport i łączność oraz liczbę rannych w wypadkach drogowych na tle gęstości dróg krajowych, wojewódzkich i powiatowych. Pod względem wy-

${ }^{7}$ Ibid. 
datków budżetowych gmin i miast na prawach powiatu, województwo łódzkie plasuje się na 8 miejscu wśród regionów kraju. Wśród wszystkich województw Polski w województwie łódzkim dominują głównie drogi powiatowe. Bardzo wyraźna jest również przewaga łódzkiego pod względem liczby rannych w wypadkach (na 100 tys. pojazdów) - 318, która znacząco przekracza średnią dla kraju na poziomie 203 osób rannych na 100 tys. pojazdów. Interpretacja tak wysokiego poziomu nie jest jednoznaczna. Główne przyczyny wypadków na polskich drogach można ująć w dwóch grupach. Pierwsza obejmuje elementy związane z zachowaniami użytkowników dróg i jest to: nadmierna prędkość, nieustępowanie pierwszeństwa przejazdu i nieprawidłowe wyprzedzanie oraz prowadzenie pojazdów pod wpływem alkoholu. Druga grupa to przyczyny związane ze złym stanem technicznym dróg, ciągle zwiększającą się liczbą pojazdów oraz niedostosowaniem infrastruktury drogowej do potrzeb ${ }^{8}$. Dzięki przeprowadzonej analizie niełatwo jest w sposób jednoznaczny wnioskować na temat zróżnicowania województw w odniesieniu do dostępności drogowej i kolejowej oraz pozycji województwa łódzkiego w tym świetle. Gęstość sieci dróg i linii kolejowych oraz obciążenie infrastruktury są najwyższe w centralnej, południowej i zachodniej Polsce. W przypadku sieci dróg krajowych najniższą gęstością odznaczają się regiony południowo-wschodniej Polski.

Wskaźniki motoryzacji są najwyższe w centralnej Polsce, najniższe w regionach peryferyjnych, zarówno na północy, jak i wschodzie kraju. Wysokie obciążenie dróg pojazdami jest charakterystyczne dla województw centralnej i południowej Polski, w których usytuowane są duże aglomeracje. Najniższe wartości wyżej wymienionych wskaźników zaobserwowano natomiast w województwach wschodniej Polski oraz województwie zachodniopomorskim. Można zatem przyjąć, że mimo relatywnie wysokiej gęstości dróg utwardzonych i wysokiej dostępności przez sieć drogową do ludności oraz do rynku towarów i usług, województwa centralnej i południowej Polski wykazują najwyższe potrzeby w zakresie inwestycji w infrastrukturę drogową, ze względu na najwyższe wskaźniki obciążenia dróg oraz natężenia ruchu. Na tle analizowanych zmiennych województwo łódzkie jest relatywnie dobrze dostępne względem całego obszaru Polski, szczególnie z uwagi na położenie w istniejącej (a zwłaszcza docelowej), krajowej i międzynarodowej sieci połączeń (Rosik 2008).

Poprawa dostępności regionu poprzez rozbudowę i modernizację sieci transportowych stanowi cel podejmowanych działań w skali od międzynarodowej do lokalnej (obszar Unii Europejskiej, poszczególne państwa członkowskie, regiony, miasta i gminy) (Janecki, Krawiec 2009).

Procesy modernizacji i rozbudowy infrastruktury transportowej bezpośrednio wpływają na poprawę dostępności transportowej obszarów alokacji inwestycji w sieci drogowe i kolejowe. Tym samym nowo powstałe elementy infrastruk-

\footnotetext{
${ }^{8}$ www.policja.pl (19.10.2013).
} 
tury transportowej, jak i zmodernizowane jej składniki są ważnym czynnikiem rozwoju usług w sektorze TSL (transport, spedycja, logistyka). Daje to również możliwości zwiększenia zakresu ilościowego i poprawę jakości dotychczas dostępnej na rynku oferty transportowej. Rozwój usług transportowych, zaliczanych do podstawowych usług gospodarczych, stwarza szanse i możliwości kreowania różnych rodzajów aktywności ekonomicznej i społecznej (ibid.). Zatem rozwój infrastruktury transportowej także pośrednio generuje pozytywne efekty wynikające z poprawy dostępności transportowej. Atrakcyjna oferta usług transportowych jest bowiem istotnym wyznacznikiem konkurencyjności poszczególnych regionów, aglomeracji i miast.

\subsection{Sieć osadnicza a system transportowy regionu lódzkiego}

Na kształt sieci osadniczej danego obszaru miało wpływ wiele uwarunkowań o charakterze zewnętrznym. Do najważniejszych z tych czynników należy zaliczyć warunki naturalne środowiska geograficznego, określające pozytywnie lub negatywnie szanse zasiedlenia i zagospodarowania obszaru, a ponadto stwarzające określone warunki jego drożności oraz organizacji polityczno-terytorialnej. Wskazać należy również układ głównych dróg i szlaków handlowych, stanowiący kręgosłup każdego obszaru. Kulesza i Koter (1998) wskazują ponadto na stan zaludnienia obszaru i związany z nim stopień gęstości wiejskiej sieci osadniczej oraz poziom rozwoju gospodarczego obszaru i jego kontakt z krainami ościennymi. Listę podstawowych czynników uzupełnić należy o charakter terytorialnej organizacji struktur polityczno-administracyjnych oraz położenie ich ośrodków centralnych, obszarów rdzeniowych, jak również peryferii.

W przypadku województwa łódzkiego przede wszystkim trzeba wskazać położenie regionu w strefie wododziału I rzędu. Do czynników geograficznych dodać należy również lokalizację na obszarze granicznym pomiędzy pasem nizin Polski środkowej oraz wyżyn Polski południowej. Sieć osadniczą ukształtowały również czynniki historyczne. W dziejach osadniczych omawianego obszaru wyróżnić można co najmniej pięć okresów (Rosin 1971). Pierwszy z nich obejmuje schyłek okresu wczesnofeudalnego, tzn. od przełomu XI i XII w., kiedy pojawiają się pierwsze wzmianki pisane o osiedlach typu miejskiego, do 1466 r., tj. początku okresu gospodarki czynszowej. Drugi to okres gospodarki folwarczno-pańszczyźnianej od 1467 do 1763 r. Trzeci okres to rozkład feudalizmu i początki kształtowania się gospodarki kapitalistycznej. Kolejny okres obejmuje rozwój kapitalizmu i industrializacji od 1871 do 1945 r. Ostatni z okresów to czas trwania PRL i przemian ustrojowo-gospodarczych po $1989 \mathrm{r}$. (Kulesza, Koter 1998). 
Województwo łódzkie w swoich obecnych granicach obejmuje obszary graniczne głównych dzielnic historycznych Polski. Poważną rolę w kształtowaniu sieci osadniczej województwa miały również czynniki społeczno-gospodarcze. W XIX w. na skutek intensywnego uprzemysłowienia rozwinęły się ośrodki wyspecjalizowane w przemyśle lekkim. Procesy industrializacji przede wszystkim wpłynęly na strukturę i wielkość sieci osadniczej na obszarach sąsiadujących z Łodzią. Powstały kolejne ośrodki przemysłowe, a istniejące wcześniej przeszły gruntowne przekształcenia. Zapisy Planu zagospodarowania przestrzennego województwa tódzkiego (2010) charakteryzują region pod względem historycznym, społecznym i gospodarczym jako obszar stykowy, co skutkuje niskim poczuciem tożsamości regionalnej i znacznym zróżnicowaniem funkcjonalno-przestrzennym. Silna tożsamość regionalna występuje wyłącznie na poziomie lokalnym i subregionalnym. W wyniku takich okoliczności ukształtowała się sieć osadnicza będąca zbiorem różnych układów osadniczych, złożonych z małych i średnich miast, które odpowiadają podziałom polityczno-administracyjnym o charakterze historycznym. Łódź powinna występować w roli spajającej społeczność regionu w koherentną całość.

Ludność miast, według stanu na 31 grudnia 2012 r. wynosi 1405122 mieszkańców, co stanowi 55,7\% udziału ludności województwa9. Największym miastem województwa jest Łódź, licząca 718960 mieszkańców, i blisko dziesięciokrotnie przewyższa pod tym względem następne w kolejności ośrodki - Piotrków Trybunalski i Pabianice. Dzięki nagromadzeniu funkcji administracyjnych i usług o znaczeniu ponadlokalnym, Łódź pełni rolę dominującą w sieci osadniczej województwa. Do najważniejszych czynników wzmacniających endogeniczny potencjał rozwojowy Łodzi należą jej tradycje rozwoju wielokulturowego oraz wielkofabrycznego przemysłu włókienniczego. Ważnym elementem jest również skumulowanie funkcji produkcyjnych, usługowych i badawczo-rozwojowych. Szczególną rolę Łodzi wzmacnia ponadto jej położenie między Wrocławiem i Poznaniem a Warszawą.

Do miast średnich o zaludnieniu wynoszącym 20-100 tys. mieszkańców należy 15 ośrodków, w tym: Piotrków Trybunalski, Pabianice, Tomaszów Mazowiecki, Bełchatów, Zgierz, Skierniewice, Radomsko, Kutno, Zduńska Wola, Sieradz, Łowicz, Wieluń, Opoczno, Aleksandrów Łódzki oraz Ozorków. W strukturze administracyjnej ośrodki z tej grupy są siedzibami powiatów ziemskich (w przypadku Piotrkowa i Skierniewic także grodzkich) oraz dodatkowo siedzibami równoległych władz miejskich i gminnych.

Miasta małe o zaludnieniu do 20 tys. mieszkańców to 28 ośrodków: Łask, Rawa Mazowiecka, Konstantynów Łódzki, Łęczyca, Głowno, Koluszki, Brzeziny, Wieruszów, Żychlin, Zelów, Poddębice, Tuszyn, Pajęczno, Sulejów, Działoszyn, Krośniewice, Drzewica, Przedbórz, Stryków, Złoczew, Rzgów, Warta, Biała Rawska, Uniejów, Kamieńsk, Wolbórz, Błaszki oraz Szadek.

${ }^{9}$ Bank Danych Lokalnych, http://www.stat.gov.pl/bdl/app/strona.html?p_name=indeks (19.09.2013). 
Miasta województwa łódzkiego są słabo zróżnicowane pod względem struktury wielkości. Cechą charakterystyczną jest wyraźny dystans pomiędzy Łodzią a kolejnymi pod względem liczby ludności miastami. W systemie osadniczym regionu łódzkiego brakuje jednostek zamieszkanych przez ponad 100 tys. mieszkańców. Powinny one pełnić rolę regionalnych ośrodków równoważenia rozwoju, a ponadto zapewniać funkcje komplementarne w stosunku do Łodzi. Występuje jednak duża zbiorowość miast o liczbie nieprzekraczającej 40 tys. mieszkańców. Wyraźne jest też zmniejszanie się wielkości miast wraz z ich oddalaniem się od Łodzi oraz nieregularne rozmieszczenie większych ośrodków. Widoczny jest również brak większych miast w części północno-wschodniej i południowo-zachodniej województwa. Największą gęstością jednostek odznacza się rejon Łódzkiego Obszaru Metropolitalnego. Stanowią one strefę silnie zurbanizowaną, oddzieloną wyraźnie od pozostałych miast województwa (Pielesiak 2012).

Plan zagospodarowania przestrzennego województwa łódzkiego (2010) dzieli województwo pod względem rozmieszczenia i poziomu rozwoju miast na część północno-zachodnią i południowo-wschodnią. Umowna linia podziału biegnie od Białej Rawskiej przez Rawę Mazowiecką, Koluszki, Zelów do Wielunia. Pierwsza z części charakteryzuje się nieregularną, lecz gęstą siecią miast o wyraźnie zróżnicowanym poziomie rozwoju społeczno-gospodarczego. Atrakcyjność tych ośrodków umożliwia jednak zrównoważoną obsługę całego obszaru. Drugi z wydzielonych terenów województwa jest mniej zróżnicowany pod względem możliwości obsługi. Najsilniejszy ośrodek tego obszaru to Piotrków Trybunalski, natomiast jego potencjał nie jest w stanie oddziaływać na cały obszar południowo-wschodni. Pozostałe ośrodki tej części województwa charakteryzują się wyraźnym rozproszeniem przestrzennym.

Poddając analizie rozwój stosunków transportowych na badanym obszarze, należy wskazać, iż w okresie średniowiecza ziemie te przecinało kilka szlaków oraz ich odgałęzień, mających charakter dróg międzynarodowych. Do takich można zaliczyć m.in. tzw. drogi ruskie, biegnące ze wschodu na zachód i północny zachód, drogi ze Śląska do Wielkopolski, z Węgier nad Bałtyk, a ponadto z Czech i Moraw na Kujawy, z przedłużeniem nad Bałtyk (Maleczyński 1926). Rejony Morza Śródziemnego z nadbałtyckimi łączył trakt handlowy zwany szlakiem bursztynowym (Sobczyński 2005). Jednym z najstarszych znanych połączeń był szlak morawsko-kujawski, znany od X-XI w., łączący Morawy z Pomorzem Gdańskim. Biegł on m.in. przez Wieluń, Sieradz, Wartę, Uniejów, Włocławek i dalej na północ. W Uniejowie miał odgałęzienie przez Turek do Konina lub Lądu, natomiast w Szadku i Warcie do Kalisza, a przez Wartkowice do Łęczycy. Na podobny czas datuje się drogę z Rusi na Pomorze Zachodnie oraz szlak rusko-śląski. Fragment tej pierwszej prowadził m.in. przez Wolbórz, Pabianice, Lutomiersk, Małyń i Uniejów, drugiego zaś przez Radomsko, Działoszyn, Toporów, Wieluń i Bolesławiec. Innymi historycznymi szlakami średniowiecznymi była również droga toruńsko-lwowska, łącząca Bałtyk z Morzem Czarnym, któ- 
ra biegła m.in. przez Kowal, Gostynin, Łowicz, Jeżów, Rawę i dalej do Radomia, gdzie łączyła się z drogą sandomiersko-łęczycką. W XIV w. straciła ona na znaczeniu wobec powstania nowego szlaku, biegnącego nieco na zachód od poprzedniego, przez Przedecz, Łęczycę, Jeżów i Inowłódz. W Łęczycy kierowała się na Brześć Kujawski i Włocławek. Nie mniej ważnymi były drogi biegnące z południa na północ, m.in. z Węgier nad Bałtyk. Jedna z nich prowadziła przez Kraków, Jędrzejów, Kielce i Sulejów, gdzie łączyła się z drogami ruskimi. Jej odnoga przekraczała Pilicę pod Przedborzem i stąd kierowała się ku Piotrkowowi. Boczne jej odnogi prowadziły przez Piotrków, Sieradz, Kalisz bądź przez Łęczycę, Dąbie, Konin i dalej do Poznania.

Już we wczesnym średniowieczu Łęczyca, Sieradz oraz Piotrków były ważnymi węzłami komunikacyjnymi o znaczeniu ponadregionalnym i utrzymały tę rangę przez następne stulecia. Przez Łęczycę przechodziły różne szlaki. Jeden z nich - wschodni - biegnący przez Radom i Inowłódz, po przekroczeniu tzw. Błot Łęczyckich, dzielił się na dwa ramiona. Należy zauważyć, że przy głównych drogach handlowych prowadzących z Wielkopolski na Śląsk, Mazowsze, Pomorze lub do Małopolski zostało zlokalizowane później aż ok. 85-90\% miast (Wiesiołowski 1980). W późniejszym czasie nastąpiła zasadnicza zmiana roli poszczególnych szlaków komunikacyjnych w związku z decyzjami panujących. W przypadku ziem dzisiejszego województwa łódzkiego dotyczyło to m.in. zmiany tras handlu bałtycko-węgierskiego (Kulesza, Koter 1998).

Poddając analizie relacje pomiędzy aktualną siecią osadniczą województwa a jego siecią transportową, należy nawiązać do zasady komunikacyjnej Christallera (1963). Jej autor wskazuje, że z punktu widzenia zasady komunikacyjnej korzystne jest takie ukształtowanie rozmieszczenia ośrodków centralnych, w którym możliwie dużo miejscowości o większym znaczeniu leży na linii komunikacyjnej łączącej w sposób możliwie najtańszy ośrodki najważniejsze (rycina 2.6).

W warunkach dominacji zasady komunikacyjnej ośrodki centralne położone są zatem na szlakach komunikacyjnych stanowiących linie proste, rozchodzące się promieniście z ważniejszych ośrodków, przy czym teoretycznie optymalna liczba takich linii wynosi sześć (Potrykowski, Taylor 1982). W przypadku województwa łódzkiego tego typu układ wyraźnie zarysowuje się dla Łodzi i rozchodzących się od niej promieniście pięciu dróg krajowych i jednej wojewódzkiej. Podobny układ występuje w przypadku Piotrkowa Trybunalskiego, od którego w kierunku mniejszych jednostek prowadzi siedem dróg. Widoczna jest tendencja do jak najlepszego połączenia głównego ośrodka centralnego z jego obszarem rynkowym w ten sposób, by główne linie komunikacyjne przebiegały przez jak największą liczbę ważniejszych ośrodków centralnych. Dla pozostałych głównych ośrodków województwa nie występują podobne zależności ${ }^{10}$.

${ }^{10}$ Należy jednak pamiętać, że twierdzenia te mają charakter przede wszystkim dydaktyczny, są bowiem cennymi przykładami poprawnego rozumowania. Przyjmowane przez klasyków założe- 


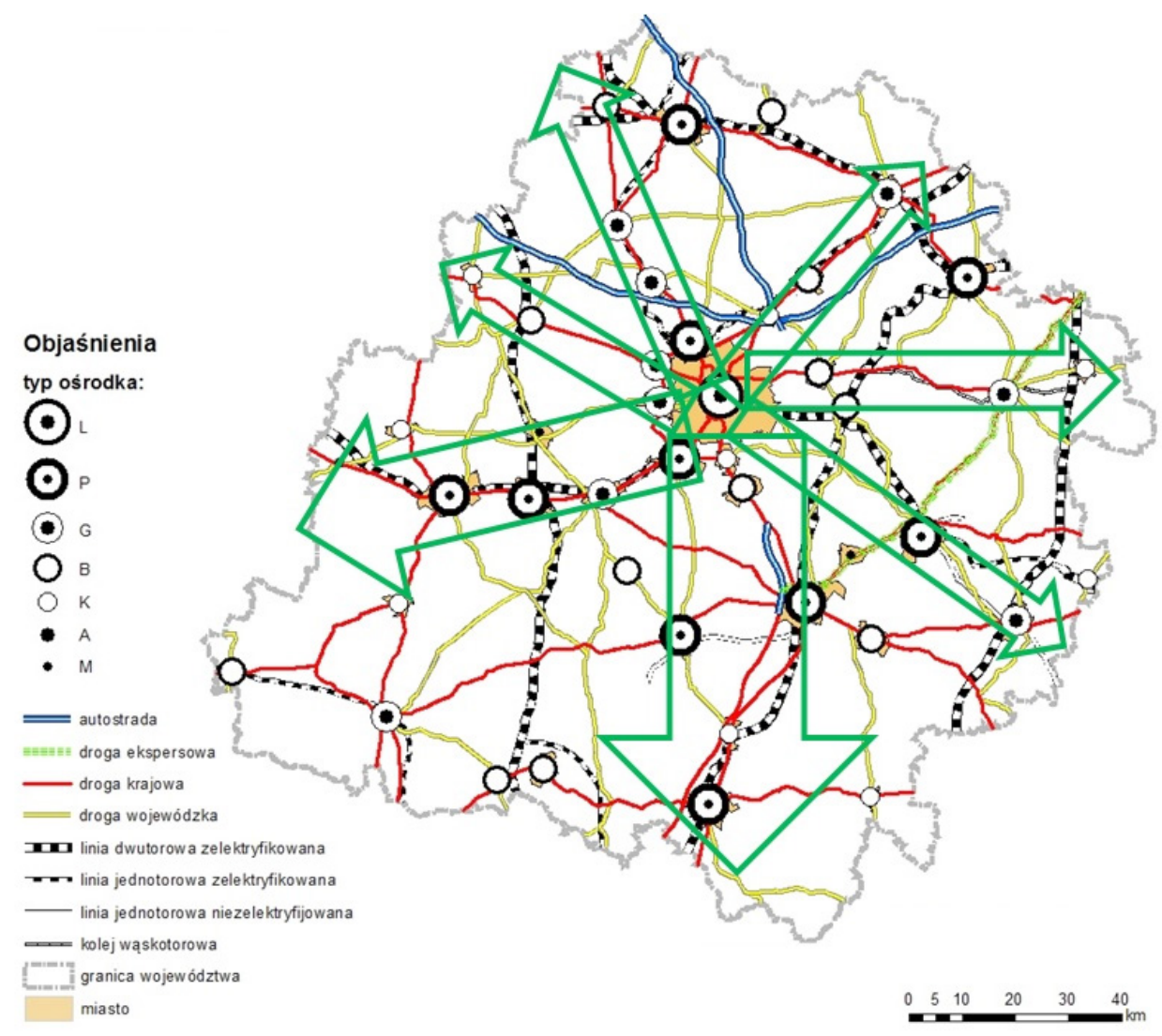

Rycina 2.6. Sieć osadnicza województwa łódzkiego w świetle zasady komunikacyjnej Christallera; zielonymi strzałkami przedstawiono główne linie komunikacyjne Źródło: opracowanie własne

Województwo łódzkie jest regionem relatywnie dobrze wyposażonym w elementy sieci drogowej (rycina 2.7), co potwierdzają przedstawione wcześniej wskaźniki. Pomimo stosunkowo dużej gęstości dróg konieczna jest systematyczna kontynuacja inwestycji związanych z połączeniami z krajami Europy, w postaci autostrad i dróg ekspresowych.

Wyraźną, słabą stroną aktualnej sieci dróg w województwie łódzkim jest niezadowalający stan techniczny. Największy problem stanowi zniszczona nawierzchnia, niedopasowanie parametrów poszczególnych odcinków sieci do roli,

nia upraszczające odbiegają nadmiernie od rzeczywistości - przede wszystkim statyka, nieuwzględnianie zmian zachodzących w czasoprzestrzeni, pomijanie założenia niepewności to główne zarzuty stawiane tym teoriom. 


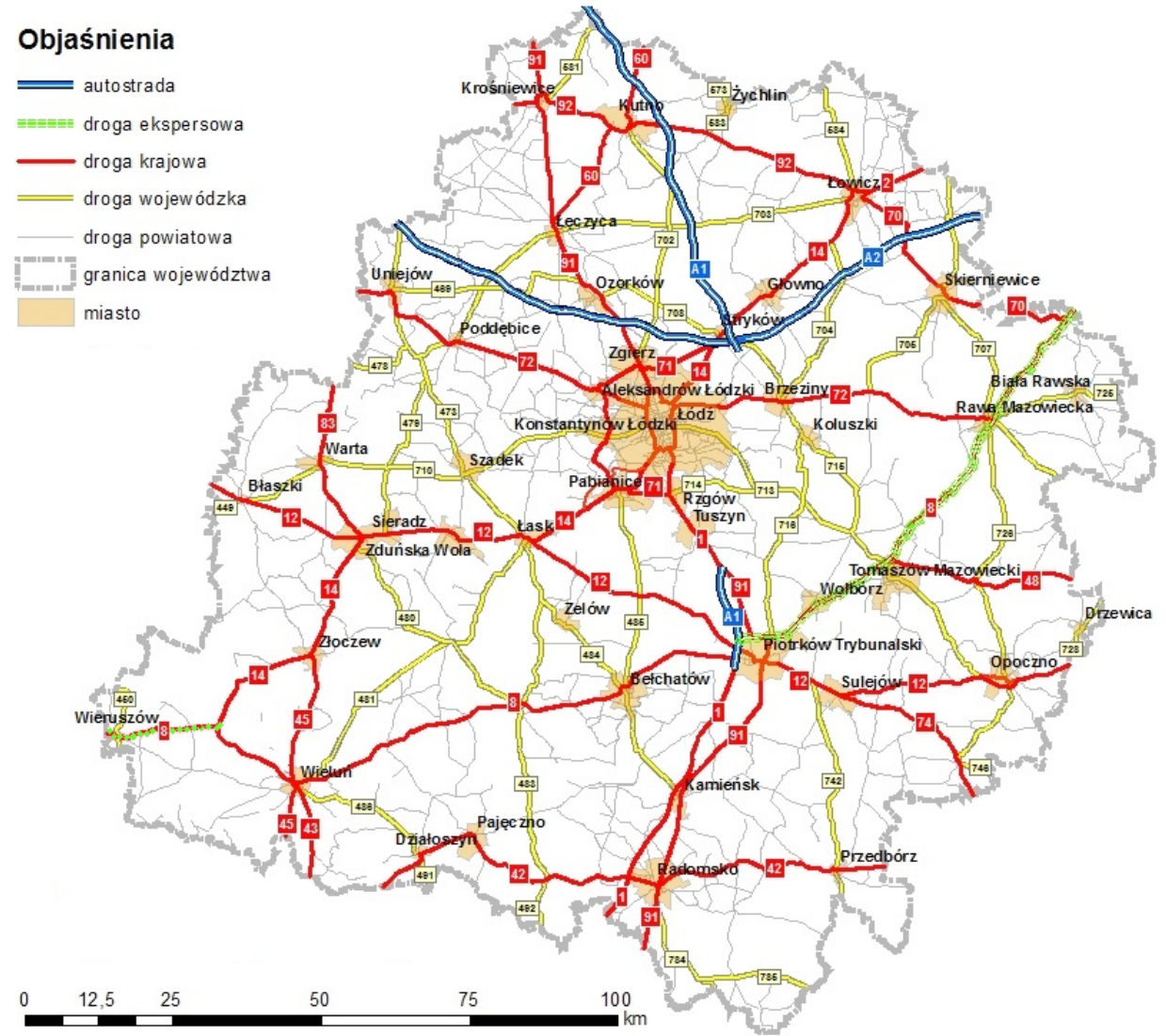

Rycina 2.7. Sieć dróg województwa łódzkiego (stan na 1.06.2014)

Źródło: opracowanie własne na podstawie danych udostępnionych przez GDDKiA oddział Łódź, Wydział Dróg Zarządu Dróg Wojewódzkich w Łodzi

jaką pełnią w całym układzie. Wymienić należy również występowanie dróg nieprzygotowanych do dużego ruchu lub ruchu ciężkich pojazdów. Problemem jest także brak obwodnic (funkcjonuje jedynie obwodnica Opoczna, Pabianic, Kutna, Krośniewic i Rawy Mazowieckiej, a GDDKiA przygotowuje się do budowy obwodnic Wielunia i Bełchatowa ${ }^{11}$ ), co powoduje prowadzenie ruchu przez tereny zabudowane, zachwianie jego płynności i kongestię.

Do najbardziej obciążonych ruchem samochodowym (głównie ciężarowym) dróg $\mathrm{w}$ kraju ${ }^{12}$ należą drogi krajowe o charakterze międzynarodowym (nr 1, 91,

${ }^{11}$ Mapa stanu budowy dróg województwie tódzkim, http://www.gddkia.gov.pl/mapa-stanu-budowy-drog_lodzkie (20.10.2013).

${ }^{12}$ Generalny Pomiar Ruchu 2010, http://www.gddkia.gov.pl/pl/987/gpr-2010 (20.09.2013). 
2, 92, 8, S8), przebiegające przez województwo łódzkie (Plan zagospodarowania przestrzennego województwa tódzkiego 2010).

Aktualna sieć kolejowa województwa łódzkiego (rycina 2.8) została ukształtowana przez kilka czynników, wśród których najważniejsze są elementy historyczne (Schiele 1998).

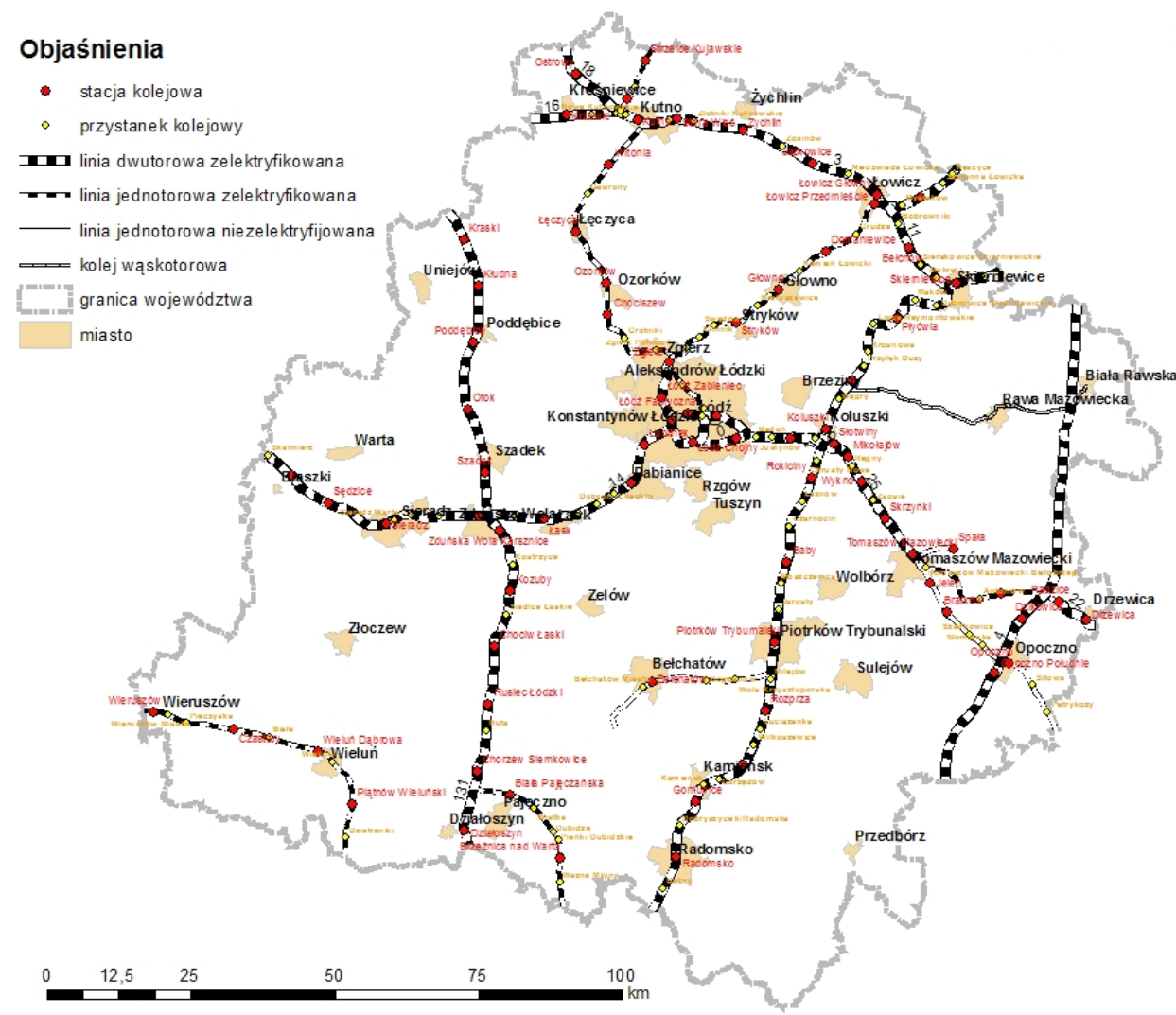

Rycina 2.8. Sieć kolejowa województwa łódzkiego

Źródło: opracowanie własne na podstawie danych udostępnionych przez PKP Polskie Linie Kolejowe S.A.

Duże znaczenie dla rozwoju sieci miały również czynniki strategiczne, gospodarcze i urbanizacyjne. Niemniej jednak przyrost długości linii może występować również na terenach, gdzie procesy gospodarcze czy urbanizacyjne są słabe, ale obszary te muszą zostać wyposażone w infrastrukturę, aby mogła finalnie dotrzeć do ważnych ośrodków rozwoju gospodarczego. Trzeba również zaznaczyć, iż na obszarze województwa łódzkiego i całej Polski centralnej i wschod- 
niej sieć linii kolejowych stworzono zanim wprowadzono drogi o nawierzchni twardej (Taylor 2007).

Sieć kolejowa Polski, po okresie maksymalnego rozwoju w latach 19791985, zaczęła się stopniowo kurczyć przy jednoczesnym zachodzeniu w niej niekorzystnych zmian jakościowych. Część tych zmian przebiegała w sposób niekontrolowany, wręcz chaotyczny. Stan techniczny sieci ulegał systematycznemu pogorszeniu, podobnie jak cały majątek kolei doświadczał dekapitalizacji i dewastacji. Trzeba pamiętać, że sieć kolejowa jest pewnym zintegrowanym systemem i na tym m.in. polega jej wartość (ibid.).

Biorąc pod uwagę połączenia kolejowe, należy wskazać znaczący problem w organizacji obsługi pociągów dalekobieżnych w województwie łódzkim. Łódź stanowi istotną barierę dla połączeń krajowych, zaburzając ich płynność poprzez wykorzystywanie tych samych linii przez pociągi podmiejskie i dalekobieżne (Suliborski i in. 2009). Łódź dzieli również sieć krajowych połączeń na dwie części obsługiwane przez dwa dworce: Fabryczny (w przebudowie) i Kaliski, które nie są wzajemnie dobrze skomunikowane. Przyczynia się to do problemów z włączaniem kolei do wewnętrznej obsługi komunikacyjnej województwa.

Rozwiązaniem umożliwiającym uniknięcie powyższych problemów mogą stać się inwestycje związane z wprowadzonym w 2008 r. rządowym Programem budowy i uruchomienia przewozów kolejami dużych prędkości w Polsce. Planowana jest realizacja linii Warszawa-Lódź-Wrocław/Poznań. Program przewiduje przejścia tunelem pod centrum Łodzi, z podziemną stacją Łódź Fabryczna. Zrealizowanie tej inwestycji uczyni Łódź niezwykle ważnym węzłem kolejowym (Plan zagospodarowania przestrzennego województwa łódzkiego 2010).

\subsubsection{Pomiary odległości}

Inwentaryzacja elementów sieci transportowych województwa łódzkiego umożliwiła wykorzystanie pierwszej z metod oceny dostępności transportowej miast - pomiarów odległości. Na etapie analiz związanych z wyposażeniem infrastrukturalnym dokonano pomiaru, biorąc pod uwagę odległości fizyczne pomiędzy miastami oraz odległości fizyczne rzeczywiste. Pomiary odległości w ujęciu czasu i kosztu zostaną przedstawione na etapie analiz funkcjonowania transportu zbiorowego i indywidualnego samochodowego. Przy określaniu odległości fizycznych pomiędzy jednostkami przyjęto zasadę pomiaru do granicy administracyjnej miasta. Odległość fizyczną należy zatem rozumieć jako najkrótszą linię prostą łączącą granice analizowanej pary miast ${ }^{13}$. Przy ustalaniu odległości fizycznych rzeczywistych wykonano pomiary, poruszając się po sieci dróg, linii kole-

${ }^{13}$ Wszystkie pomiary odległości fizycznych zostały wykonane za pomocą programu ArcMap 10.0. 


\begin{tabular}{|c|c|c|c|c|c|c|c|c|c|c|c|c|c|c|c|c|c|c|c|c|c|c|c|}
\hline & No & 0 & 0 & & 0 & 0 & 0 & $c$ & & 0 & 0 & 0 & 10 & $m$ & 0 & 0 & 0 & 0 & 0 & - & 10 & in & t \\
\hline & 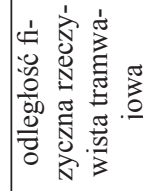 & 8 & 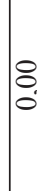 & & 8 & 8 & 8 & 8 & & $\mathbb{O}^{\circ}$ & 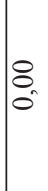 & 8 & 8 & î̃ & 8 & 8 & 8 & $\begin{array}{l}8 \\
0 \\
0\end{array}$ & $\begin{array}{l}8 \\
0 \\
0\end{array}$ & \begin{tabular}{l}
$\infty$ \\
\multirow{1}{1}{} \\
$\hat{\tilde{N}}$
\end{tabular} & 8 & $\begin{array}{l}+ \\
\infty \\
\infty \\
\infty\end{array}$ & $\frac{n}{2}$ \\
\hline & 용 & 0 & $\approx$ & & ¿ & $\vec{\sim}$ & 0 & $\stackrel{\alpha}{a}$ & & $\hat{\imath}$ & $a$ & $\approx$ & & 0 & 0 & $\infty$ & in & $=$ & $\cong$ & - & 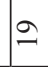 & $\infty$ & $m$ \\
\hline & 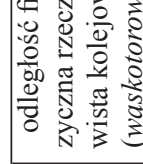 & 8 & $\begin{array}{l}\hat{\lambda} \\
\infty \\
\tilde{m} \\
\tilde{m}\end{array}$ & & $\begin{array}{l}\infty \\
\infty \\
\infty \\
\infty \\
\infty \\
c\end{array}$ & $\begin{array}{l}n \\
n \\
n \\
0 \\
n \\
n\end{array}$ & 8 & 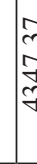 & & 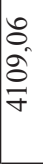 & a & $\mid \begin{array}{l}\tilde{N} \\
\tilde{N} \\
\tilde{n} \\
\tilde{n}\end{array}$ & 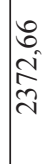 & 8 & 8 & 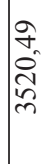 & $\begin{array}{l}\overrightarrow{0} \\
\tilde{N} \\
\tilde{N} \\
\tilde{N}\end{array}$ & $\begin{array}{l}\text { ì } \\
\tilde{n} \\
\infty \\
\infty \\
i\end{array}$ & 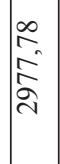 & 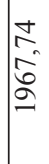 & $\mid \begin{array}{l}n \\
f \\
\tilde{\infty} \\
\infty \\
n \\
m\end{array}$ & 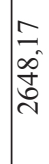 & $\begin{array}{l}\tilde{o} \\
\hat{\tilde{N}} \\
\tilde{N} \\
\tilde{N}\end{array}$ \\
\hline & ¿̊ & 0 & $\approx$ & & $\hat{\imath}$ & 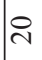 & 0 & $\approx$ & i & $\gtrsim$ & a & ป & & 0 & 0 & $=$ & in & $=$ & $\simeq$ & - & $\infty$ & $\infty$ & $m$ \\
\hline & 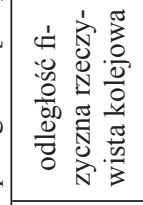 & 8. & $\begin{array}{l}\widehat{े} \\
\infty \\
\tilde{m} \\
\tilde{m}\end{array}$ & & $\begin{array}{l}8 \\
\vdots \\
0 \\
n \\
n\end{array}$ & $\begin{array}{l}n \\
n \\
n \\
0 \\
0 \\
n\end{array}$ & 8 & $\begin{array}{l}y \\
y \\
y \\
y \\
y \\
y\end{array}$ & & $\begin{array}{l}8 \\
\frac{8}{8} \\
\frac{8}{7}\end{array}$ & مे & $\begin{array}{l}\hat{N} \\
\tilde{N} \\
\tilde{n} \\
\tilde{n}\end{array}$ & 离 & 8 & 8 & 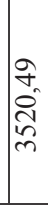 & $\begin{array}{l}\overrightarrow{0} \\
\tilde{N} \\
\tilde{N} \\
\tilde{N}\end{array}$ & $\begin{array}{l}\text { ì } \\
\text { in } \\
\infty \\
\infty \\
\text { N }\end{array}$ & 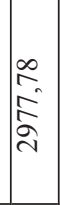 & $\frac{2}{\sqrt{2}}$ & \begin{tabular}{l}
$n$ \\
\multirow{2}{*}{} \\
$\infty$ \\
$\infty$ \\
$n$ \\
$n$
\end{tabular} & 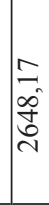 & 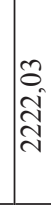 \\
\hline & $\stackrel{\text { ¿ }}{2}$ & in & 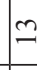 & & $\stackrel{F}{F}$ & mे & $=$ & 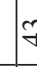 & & $\vec{\nabla}$ & $\tilde{N}$ & $\approx$ & 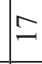 & m & i & $\infty$ & $r$ & $\tilde{\approx}$ & సे & - & $\tilde{m}$ & 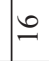 & N \\
\hline & 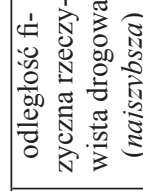 & 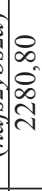 & 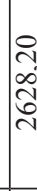 & & 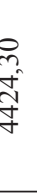 & 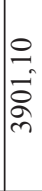 & 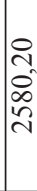 & 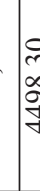 & & 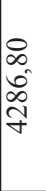 & \begin{tabular}{l}
0 \\
$\cdots$ \\
\multirow{2}{2}{} \\
2
\end{tabular} & 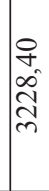 & $\begin{array}{l}\mathcal{D} \\
\tilde{N} \\
\infty \\
0 \\
\mathcal{D}\end{array}$ & 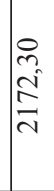 & $\begin{array}{l}\stackrel{1}{1} \\
0 \\
0 \\
2 \\
\text { mे }\end{array}$ & $\begin{array}{l}8 \\
\text { m } \\
\infty \\
2\end{array}$ & $\begin{array}{l}\text { } \\
\hat{2} \\
\tilde{n} \\
\approx\end{array}$ & $\begin{array}{l}0 \\
i \\
n \\
0 \\
0 \\
0\end{array}$ & $\begin{array}{l}0 \\
m \\
0 \\
0 \\
0 \\
ల\end{array}$ & $\begin{array}{l}8 \\
0 \\
\text { in } \\
\infty \\
-1\end{array}$ & $\begin{array}{l}8 \\
8 \\
\dot{0} \\
\infty \\
m\end{array}$ & 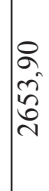 & $\mid \begin{array}{l}8 \\
a \\
2 \\
\end{array}$ \\
\hline & ํㅗㄹ. & $r$ & $\stackrel{0}{\circ}$ & & F & లి & $a$ & 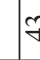 & & $\vec{\gamma}$ & $\stackrel{\sim}{~}$ & $\cong$ & $\cong$ & $m$ & $\bar{m}$ & $\hat{m}$ & $\infty$ & $\stackrel{\nabla}{\sim}$ & $\stackrel{\infty}{\sim}$ & - & 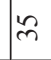 & 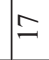 & 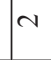 \\
\hline & 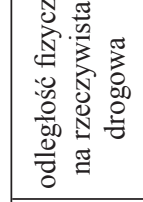 & 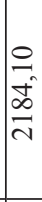 & 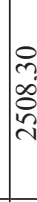 & & 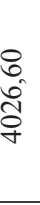 & $\begin{array}{l}0 \\
\tilde{N} \\
0 \\
0 \\
\infty\end{array}$ & $\begin{array}{l}n \\
\infty \\
N \\
\tilde{N} \\
\end{array}$ & $\begin{array}{l}8 \\
f \\
f \\
f \\
f \\
f\end{array}$ & & $\begin{array}{l}0 \\
m \\
m \\
\frac{1}{\sigma} \\
\dot{a}\end{array}$ & $\begin{array}{l}0 \\
\stackrel{0}{0} \\
\stackrel{+}{+}\end{array}$ & 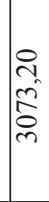 & $\mid \begin{array}{l}0 \\
\stackrel{0}{d} \\
\stackrel{d}{d}\end{array}$ & 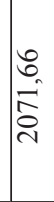 & $\begin{array}{l}i n \\
2 \\
\hat{2} \\
\hat{n}\end{array}$ & $\begin{array}{l}\infty \\
\infty \\
\\
\\
m\end{array}$ & 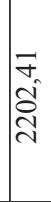 & $\begin{array}{l}0 \\
n \\
2 \\
\infty \\
\infty \\
\sim\end{array}$ & $\begin{array}{l}8 \\
8 \\
n \\
n \\
m\end{array}$ & 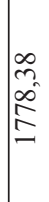 & $\begin{array}{l}0 \\
0 \\
0 \\
0 \\
0 \\
0\end{array}$ & 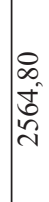 & 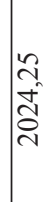 \\
\hline & $\begin{array}{l}\dot{1} \\
\stackrel{2}{2}\end{array}$ & $r$ & I & & F & $\hat{m}$ & $a$ & $\vartheta$ & & ले & 9 & $\approx$ & $\cong$ & $m$ & $\infty$ & $\tilde{m}$ & $\infty$ & $\tilde{\sim}$ & $\stackrel{m}{\text { e }}$ & - & $\dddot{m}$ & 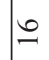 & N \\
\hline & 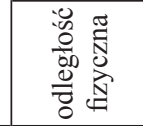 & 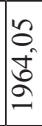 & 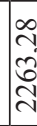 & & 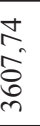 & $\begin{array}{l}8 \\
0 \\
0 \\
\infty \\
n\end{array}$ & 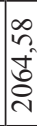 & 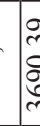 & & $\begin{array}{l}\tilde{N} \\
\infty \\
\infty \\
\vec{f} \\
m\end{array}$ & $\begin{array}{l}\hat{\infty} \\
\text { d } \\
\stackrel{+}{+}\end{array}$ & 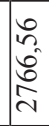 & $\begin{array}{l}\hat{\partial} \\
\hat{\infty} \\
\frac{\partial}{N}\end{array}$ & $\begin{array}{l}n \\
n \\
\infty \\
\infty \\
-1\end{array}$ & $\begin{array}{l}0 \\
\hat{i} \\
m \\
m\end{array}$ & 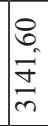 & \begin{tabular}{l}
2 \\
\multirow{2}{*}{} \\
2
\end{tabular} & 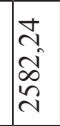 & 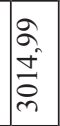 & $\begin{array}{l} \pm \\
m \\
\infty \\
\infty \\
n \\
n\end{array}$ & 离 & 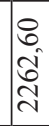 & $\begin{array}{l}2 \\
2 \\
\infty \\
-1\end{array}$ \\
\hline & $\begin{array}{l}\stackrel{0}{0} \\
\stackrel{\Xi}{*} \\
\stackrel{\Xi}{\Sigma}\end{array}$ & 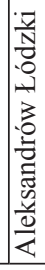 & 䓂 & 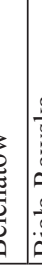 & 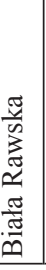 & 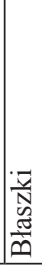 & 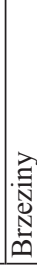 & 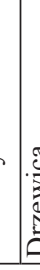 & 逆 & 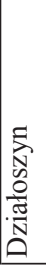 & $\frac{O}{0}$ & 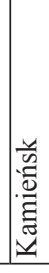 & 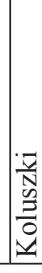 & 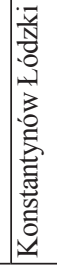 & 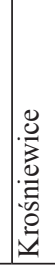 & 总 & 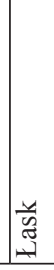 & 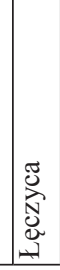 & 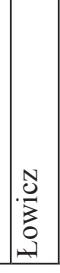 & 然 & 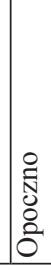 & $\begin{array}{l}3 \\
0 \\
0 \\
\vdots \\
\vdots \\
0 \\
0 \\
0\end{array}$ & 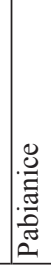 \\
\hline
\end{tabular}


\begin{tabular}{|l|l|l|l|l|l|l|l|l|l|l|l|l|l|l|l|l|l|l|l|l|l|l|l|}
\hline 0 & 0 & 0 & 0 & 0 & 0 & 0 & 0 & 0 & 0 & 0 & 0 & 0 & 0 & 0 & 0 & 0 & 0 & 0 & 0 & 0 & 4 & 0 & 0 \\
\hline
\end{tabular}

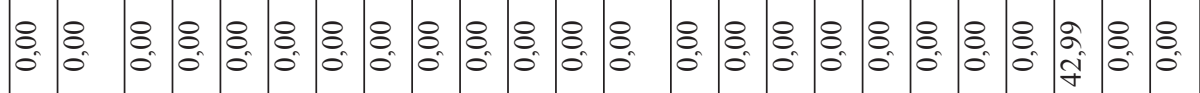

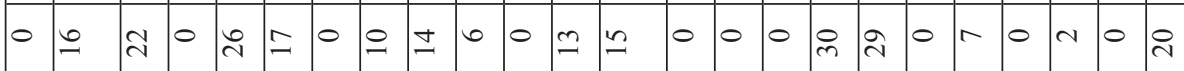

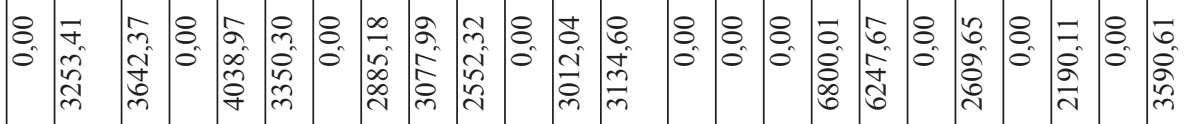

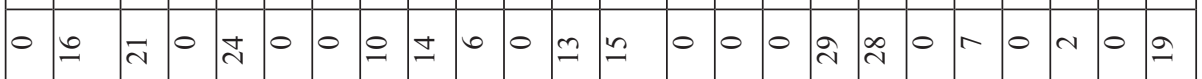

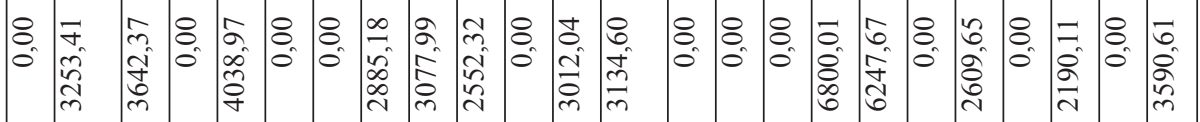

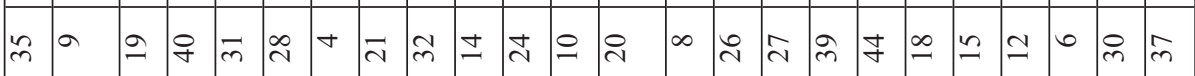

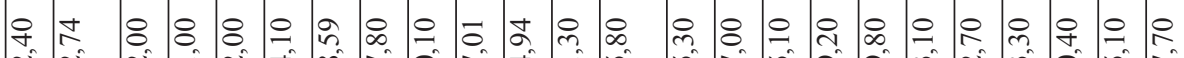

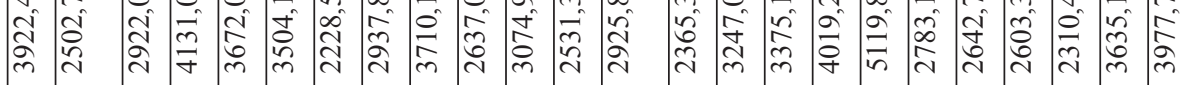

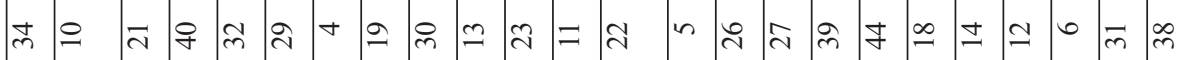

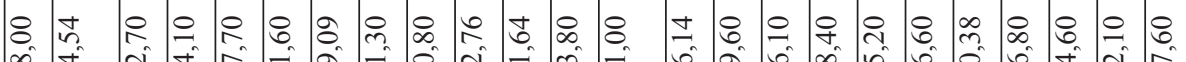

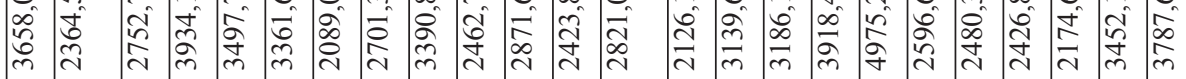

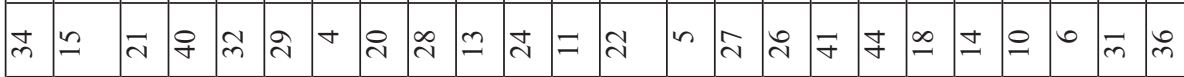

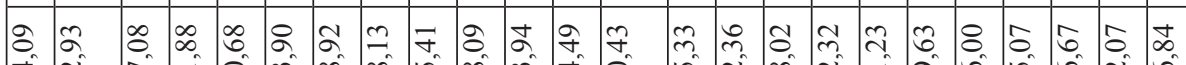

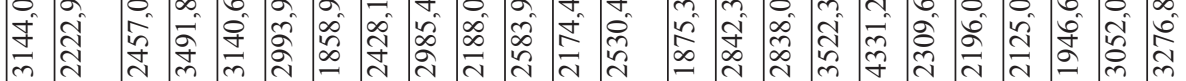

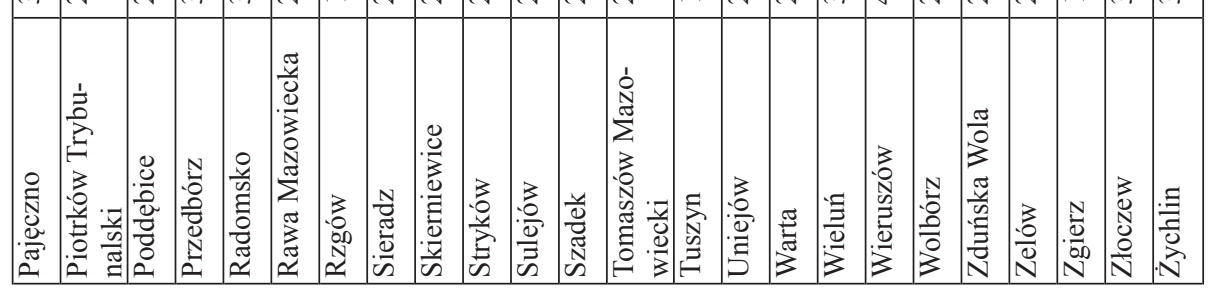

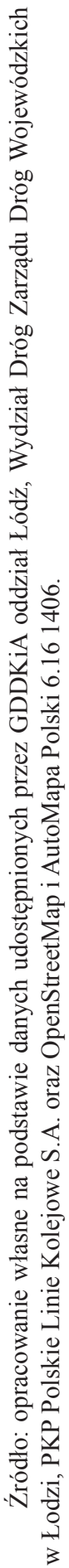


jowych i tramwajowych województwa łódzkiego (tabela 2.1). Dodatkowo obliczono odległości fizyczne rzeczywiste dla ruchu samochodowego, ale przyjęto wariant podróży możliwie najszybszej.

Do ustalenia tras dla obydwu założeń wykorzystano aplikację AutoMapa Polski 6.16 1406. Przy ustalaniu połączenia najszybszego przyjęto wstępne założenie, że jedynym czynnikiem determinującym prędkość poruszania się pojazdów są ograniczenia prędkości wynikające z prawa o ruchu drogowym. Tym samym wyeliminowano wszelkie inne elementy, takie jak np. kongestia czy ukształtowanie terenu (ujęte w dalszej części pracy), i do analizy włączono teoretyczny czas przejazdu. Po wskazaniu przez aplikację nawigacyjną trasy o narzuconej charakterystyce pomiędzy przyjętą parą miast, każdorazowo była ona weryfikowana w świetle przygotowanej uprzednio bazy GIS z siecią osadniczą i transportową województwa łódzkiego ${ }^{14}$. Wykorzystanie aplikacji pozwoliło na znaczną optymalizację i większą dokładność pomiarów. Dzięki przyjętemu założeniu pomiarów w dwóch wymiarach (najkrótszym i najszybszym) można było uchwycić poziom substytucyjności połączeń i uzyskać znacznie szerszy materiał do dalszych analiz. Przy ustalaniu odległości pomiędzy miastami w sieci drogowej przyjęto zasadę pomiaru do granicy miasta w przypadku dróg o nieograniczonej dostępności i do pierwszego możliwego zjazdu z autostrady lub drogi ekspresowej, jeśli znajduje się $\mathrm{w}$ granicach miasta. Odległości fizyczne rzeczywiste obliczono również dla połączeń kolejowych. W ich przypadku do analizy nie włączono ujęcia połączeń najszybszych. Jak wynika z przeprowadzonego badania, połączenia najkrótsze są również połączeniami najszybszymi, przy przyjęciu podróży zgodnie z ustalonym rozkładem jazdy (udostępnionym przez Polskie Koleje Państwowe S.A. ${ }^{15}$ ) bez jakichkolwiek zakłóceń. Obliczenia tras pomiędzy poszczególnymi parami miast posiadającymi dostęp do kolei dokonano na podstawie danych pozyskanych od PKP Polskich Linii Kolejowych S.A. obrazujących sieć kolejową województwa łódzkiego w postaci grafu fizycznego oraz warstwy wektoro$w^{16}{ }^{16}$. Na potrzeby analizy połączeń kolejowych przyjęto również wariant biorący pod uwagę podróż liniami kolei wąskotorowej. W przestrzeni województwa łódzkiego funkcjonuje jedynie linia Rogów-Rawa Mazowiecka-Biała Rawska ${ }^{17}$.

${ }^{14}$ Baza została przygotowana w oparciu o dane udostępnione przez Generalną Dyrekcję Dróg Krajowych i Autostrad - oddział w Łodzi, Wydział Dróg Zarządu Dróg Wojewódzkich w Łodzi oraz informacje pozyskane $\mathrm{z}$ baz internetowych takich jak Geoportal i OpenStreetView.

15 http://www.rozklad-pkp.pl/bin/query.exe/pn? (25.10.2014).

${ }^{16}$ Dane zostały uzupełnione o informacje zawarte w portalu Ogólnopolskiej Bazy Kolejowej (www.bazakolejowa.pl, 28.10.2013).

${ }^{17}$ Kolej wąskotorowa łącząca Rogów z Rawą Mazowiecką i Białą Rawską powstała w 1915 r. podczas pierwszej wojny światowej, jako kolej wojskowa polowa, która zaopatrywała front w żywność oraz broń i amunicję. Po odzyskaniu przez Polskę niepodległości została wcielona w struktury nowo powstałych Polskich Kolei Państwowych. W takim stanie funkcjonowały do 2001 r., kiedy podjęto decyzję o jej likwidacji. Dzięki Fundacji Polskich Kolei Wąskotorowych i Starostwu Powia- 
Nieczynna jest już Krośniewicka Kolej Dojazdowa oraz Piotrkowska Kolej Dojazdowa ${ }^{18}$. Powyższe linie poza brakiem funkcjonujących przewozów (brakiem taboru) charakteryzują się również znacznymi ubytkami torów, co dyskwalifikuje je $\mathrm{z}$ analizy nawet jako potencjalny sposób podróży. Uzupełnieniem pomiarów odległości jest badanie sieci tramwajowej w województwie łódzkim (rycina 2.9).

Obejmuje ona jedynie pięć ośrodków: Łódź, Pabianice, Zgierz, Ozorków i Konstantynów Łódzki. Do pomiaru odległości przejazdu tramwajem wykorzystano dane udostępnione przez Zarząd Dróg i Transportu w Łodzi. W przypadku połączeń kolejowych i tramwajowych pomiarów dokonywano pomiędzy ostatnim przystankiem/stacją w mieście początku pomiaru i pierwszym przystankiem/ stacją w granicach miasta zakończenia pomiaru. Dokonano pomiarów pomiędzy wszystkimi możliwymi parami miast, uzyskując dostępność relatywną. Wyniki zostały umieszczone w macierzy 44 na 44 dla połączeń drogowych, 29 na 29 dla połączeń kolejowych (30 na 30 przy uwzględnieniu linii wąskotorowych) oraz 5 na 5 dla połączeń tramwajowych. Wyznaczono również dostępność topologiczną, dzięki zmierzeniu odległości z danego miasta do wszystkich innych dostępnych danym środkiem transportu. Uzyskane na tym etapie wyniki posłużyły również w dalszej części pracy, m.in. przy analizach potencjału transportowo-osadniczego.

Pod względem odległości fizycznych w ujęciu topologicznym, najbardziej dostępnym w sieci miast województwa łódzkiego jest Łódź. Od pozostałych 43 miast dzieli ją łączna odległość 1589,34 km. Czołową pozycję Łódź zawdzięcza swojemu centralnemu położeniu w regionie i sieci osadniczej. Największa odległość do wszystkich ośrodków województwa dzieli Wieruszów. Jest to niemalże trzykrotność odległości dla Łodzi i wynosi $4331,23 \mathrm{~km}$.

W przypadku odległości fizycznych relatywnych najdłuższy odcinek występuje pomiędzy Białą Rawską a Wieruszowem i wynosi 172,24 km. Łódź jest ośrodkiem o najwyższym poziomie dostępności również przy przyjęciu odległości fizycznych rzeczywistych w ujęciu topologicznym. Suma odległości obliczanych po najkrótszych możliwych drogach wynosi 1778,38 km. Również w przypadku Wieruszowa potwierdził się jego niski poziom dostępności wynikający z 4975,20 km dzielących go od pozostałych ośrodków województwa. Największa odległość fizyczna rzeczywista relatywna dzieli w dalszym ciągu Białą Rawską i Wieruszów. Aby dotrzeć z jednego do drugiego miasta, konieczne jest przebycie $193,9 \mathrm{~km}$. Tak samo prezentuje się sytuacja przy przyjęciu odległości drogowych gwarantujących najkrótszy teoretyczny czas przejazdu. Najbardziej dostępna jest

towemu w Rawie Mazowieckiej linia pozostała i od 2002 r. jest w posiadaniu fundacji. W 2003 r. przywrócono kursowanie turystycznych pociągów pasażerskich na zamówienia grup zorganizowanych. Wprowadzono również regularne kursy dostępne dla turystów indywidualnych. Licząca $49 \mathrm{~km}$ trasa jest obecnie najdłuższą czynną linią wąskotorową w Polsce. Kolej kursuje najczęściej od trzeciej dekady kwietnia do końca września (http://www.koleje.wask.pl/ 28.10.2013).

${ }^{18} \mathrm{http}: / /$ www.koleje.wask.pl/ (28.10.2013). 


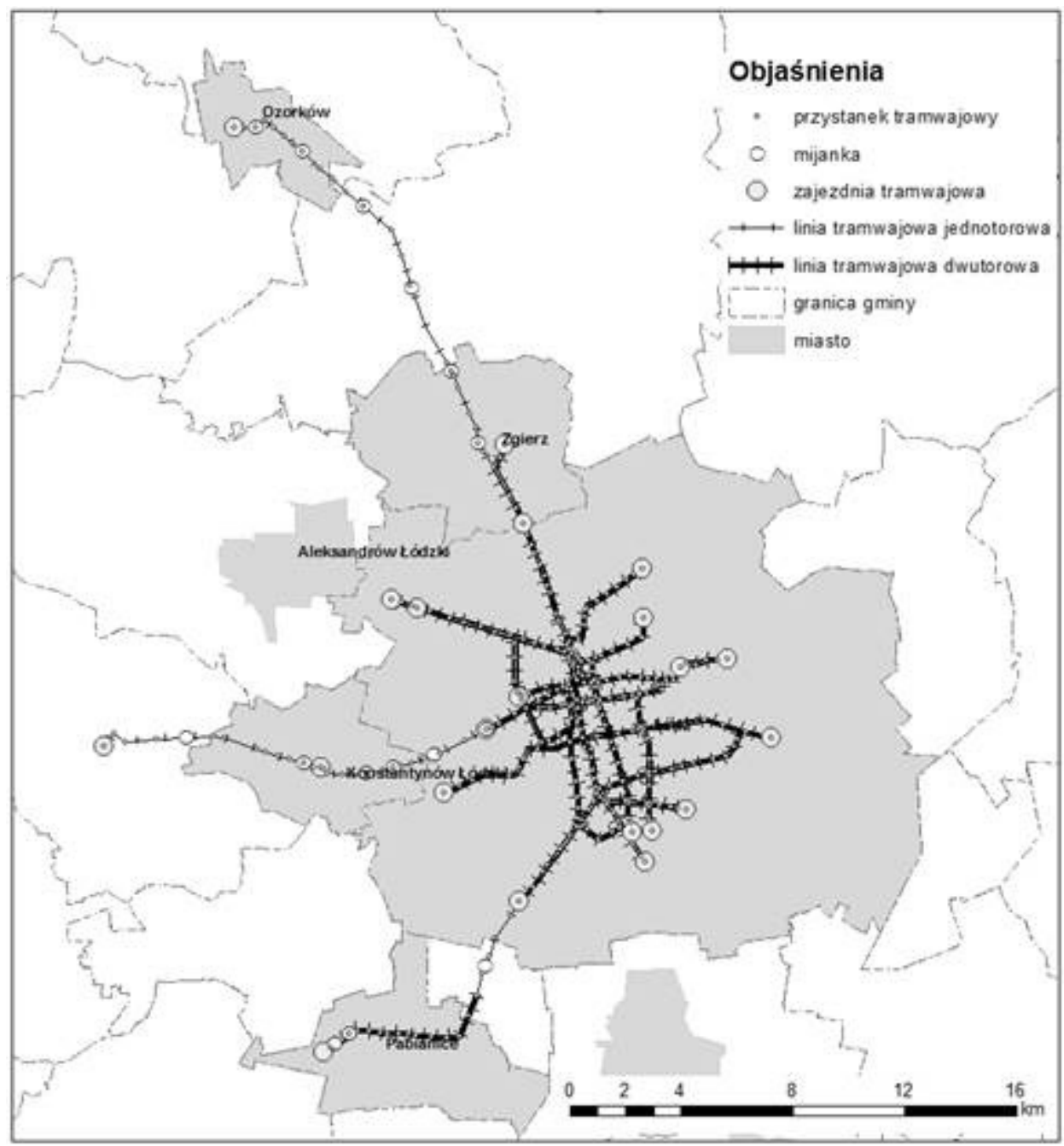

Rycina 2.9. Sieć tramwajowa w województwie łódzkim

Źródło: opracowanie własne na podstawie danych udostępnionych przez Zarząd Dróg i Transportu w Lodzi

również Łódź, a odległość topologiczna zwiększyła się o 44,22 km. Najniższym poziomem dostępności odznacza się Wieruszów, dla którego sumaryczny dystans do pozostałych miast wzrósł o 144,6 km. Zmianie uległa jednak para miast oddzielonych największą odległością. Wieruszów i Skierniewice dzieli 200,8 km przy wyborze trasy najszybszej. Poddając analizie przestrzenne zróżnicowanie topologicznej dostępności transportowej drogowej miast województwa łódzkiego 
mierzonej odległością fizyczną i fizyczną rzeczywistą (rycina 2.10), wyraźnie widoczny jest przyrost odległości wraz z oddalaniem się od centrum województwa. Ponadto im bardziej dane miasto oddalone jest od centrum, tym bardziej znaczące są różnice pomiędzy odległością fizyczną i fizyczną rzeczywistą również w ujęciu połączeń teoretycznie najszybszych. Tak wyraźna prawidłowość jest związana z charakterystyką sieci dróg województwa łódzkiego.

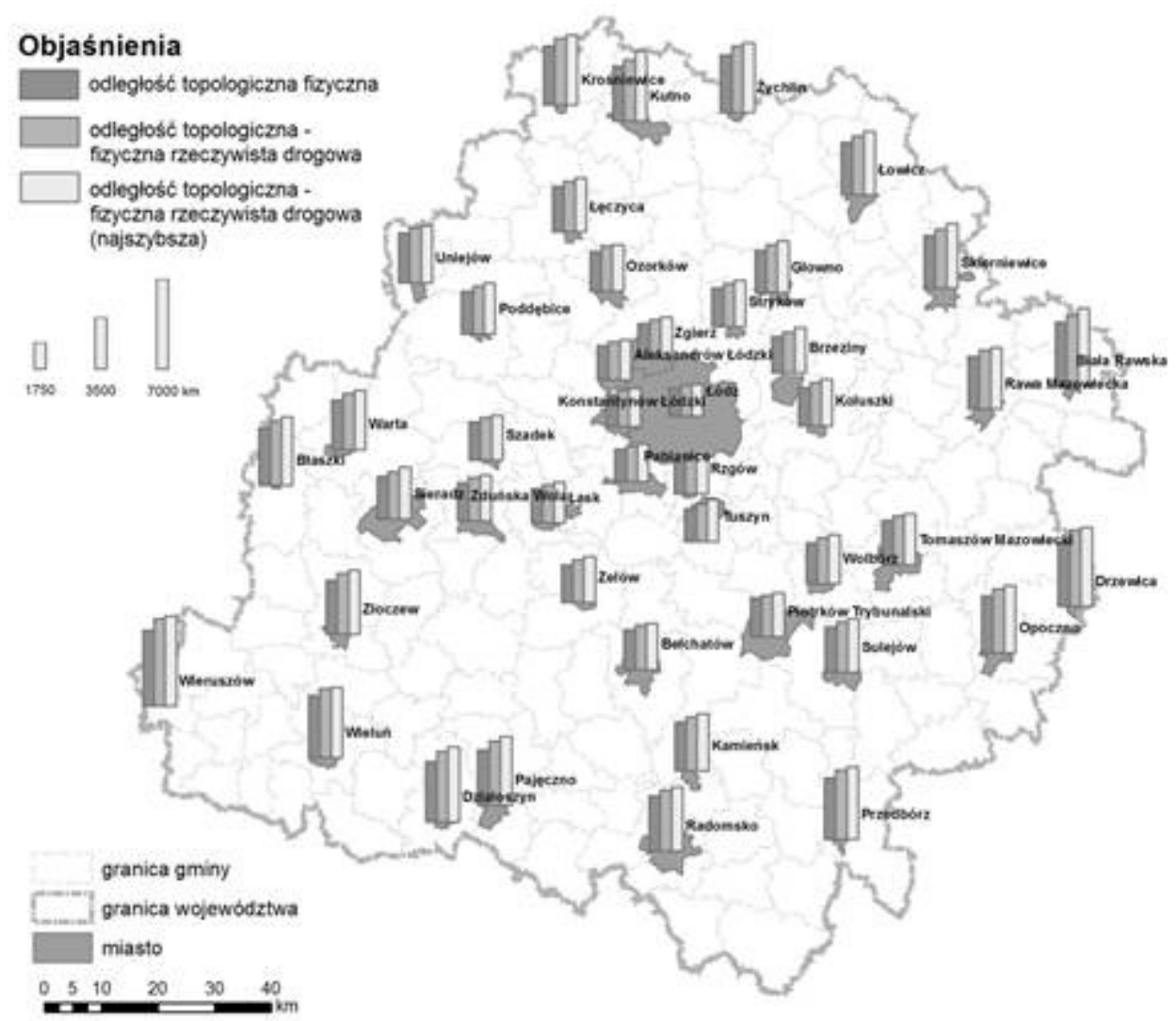

Rycina 2.10. Przestrzenne zróżnicowanie odległości topologicznych miast województwa łódzkiego w sieci drogowej

Źródło: opracowanie własne

Drogi krajowe i wojewódzkie tworzą bowiem układ promienisto-koncentryczny, co umożliwia relatywnie proporcjonalne połączenia pomiędzy centrum a peryferiami regionu. Zaburzeniem układu są drogi o ograniczonej dostępności. Ze względu jednak na ograniczoną rolę, jaką odgrywają w połączeniach we- 
wnątrzregionalnych, nie wpływają znacząco na opisywane prawidłowości przestrzenne.

Przy analizie poziomu dostępności transportowej za pomocą pomiaru odległości w sieci kolejowej województwa łódzkiego badaniem objęto 29 miast. W przypadku połączeń kolei wąskotorowej dodatkowo uwzględniono Rawę Mazowiecką. Do badania włączono linie prowadzące zarówno ruch pasażerski, jak i wyłącznie towarowy. Chociaż niniejsze opracowanie skupia się na transporcie pasażerskim, to uwzględnienie linii towarowych uzasadnić można potencjalnym ich wykorzystaniem dla przewozu pasażerów. Podobnie jak w przypadku połączeń drogowych, również w sieci kolejowej Łódź jest miastem o najwyższym poziomie dostępności. Topologiczna odległość fizyczna rzeczywista kolejowa wynosi dla Łodzi 1967,74 km, gdy dla miasta o najniższej dostępności - Wielunia - konieczne jest pokonanie $6800,01 \mathrm{~km}$. Największa odległość pośród relacji bilateralnych pomiędzy miastami województwa łódzkiego dzieli Wielun i Kutno. Istniejący układ sieci kolejowej wymusza pokonanie $381,21 \mathrm{~km}$ pomiędzy powyższymi miastami. Przestrzenne zróżnicowanie odległości topologicznych w sieci kolejowej województwa łódzkiego, podobnie jak w sieci drogowej, jest uwarunkowane odległością od centrum województwa. Przez Łódź bowiem prowadzą wszystkie połączenia relacji wschód - zachód oraz znaczna część relacji północ - południe. Zróżnicowanie nie jest tak regularne jak w przypadku sieci drogowej, co jest zdeterminowane przede wszystkim przebiegiem linii przez wyłącznie 29/30 jednostek oraz układem linii kolejowej województwa, który nawiązuje bardziej do układu szachownicowego niż promienisto-koncentrycznego.

Dokonując analizy porównawczej rzeczywistych fizycznych odległości topologicznych dla sieci drogowej i kolejowej, możliwe jest wskazanie pewnych prawidłowości (rycina 2.11). Pomimo uwzględnienia w połączeniach kolejowych o 14 jednostek mniej (pozbawionych dostępu do kolei) występują miasta, dla których odległości topologiczne kolejowe przewyższają odległości drogowe. Wynika to z przedstawionej wcześniej charakterystyki układu sieci kolejowej. Największe tego typu różnice dotyczą Wielunia oraz Wieruszowa. Do miast o tej samej specyfikacji, ale mniejszych rozbieżnościach można zaliczyć ponadto Bełchatów, Kamieńsk, Radomsko, Piotrków Trybunalski, Tomaszów Mazowiecki, Biała Rawska, Poddębice, Szadek, Łask, Łódź oraz Pabianice. Pozostałe ośrodki mające dostęp do obydwu sieci charakteryzują się większymi odległościami przy obsłudze transportu dzięki sieci drogowej. Najbardziej znaczące dysproporcje na korzyść sieci drogowej występują w przypadku Skierniewic oraz Łowicza.

Uzupełnieniem analiz dostępności transportowej w świetle pomiarów odległości jest badanie sieci tramwajowej. Jak wcześniej zaznaczono, połączeniami tramwajowymi objętych jest jedynie pięć miast województwa łódzkiego. Układ sieci tramwajowej wymusza każdorazowo przy podróży w relacji Pabianice-Konstantynów łódzki, Pabianice-Zgierz, Pabianice-Ozorków, Konstantynów Łódzki-Ozorków oraz Konstantynów Łódzki-Zgierz przejazd tramwaju przez Łódź. 


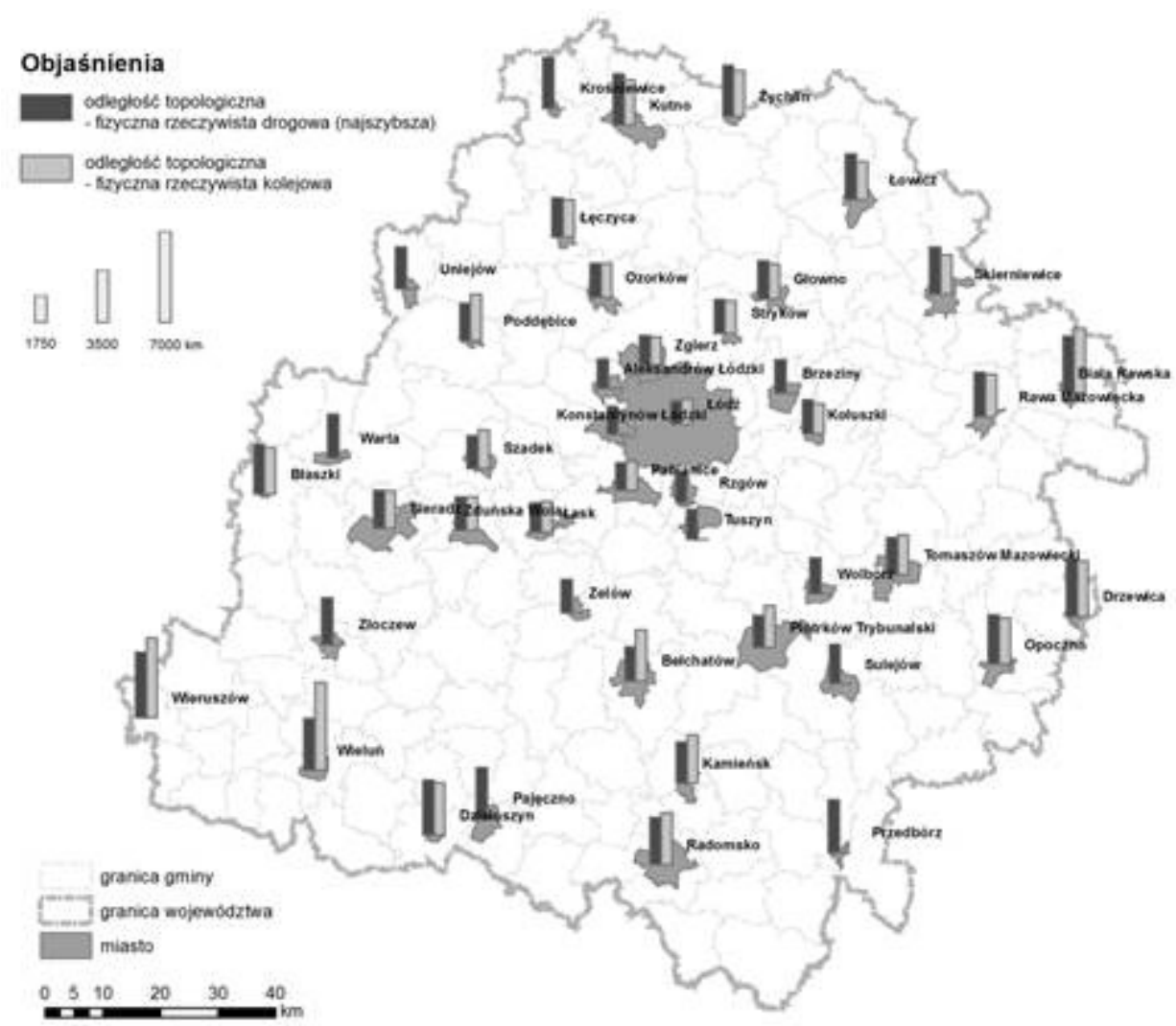

Rycina 2.11. Zestawienie odległości topologicznych miast województwa łódzkiego w sieci drogowej i kolejowej

Źródło: opracowanie własne

Bezpośrednie połączenia z trzema miastami posiada tylko Łódź, Zgierz z dwoma miastami, a pozostałe jednostki posiadają bilateralne powiązania tylko z jednym miastem. Taki układ implikuje najwyższy poziom dostępności Łodzi, zaś największe odległości fizyczne rzeczywiste tramwajowe do pozostałych miast dzielą Ozorków.

Przy założeniu przemieszczania się transportem samochodowym, kolejowym czy tramwajowym odległość fizyczna pomiędzy miastami odgrywa drugorzędną rolę. Zdecydowanie ważniejsze są odległości fizyczne rzeczywiste. To one m.in. decydują o postrzeganiu dostępności poszczególnych obszarów (w przypadku niniejszego badania miast) na poddanym analizie terenie. Dla zilustrowania różnic występujących przy przyjęciu odległości fizycznych i odległości fizycznych rzeczywistych wykonano mapy przedstawiające deformacje granicy województw 
łódzkiego w wyniku przyjęcia fizycznych rzeczywistych odległości drogowych (wariant najszybszy) i kolejowych. Analizy dla połączeń tramwajowych nie wykonano ze względu na bardzo ograniczony przestrzennie zakres oddziaływania połączeń tramwajowych ${ }^{19}$. Analizę wykonano dla Łodzi, jako miasta o najwyższym poziomie dostępności transportowej w świetle topologicznych odległości fizycznych rzeczywistych. W odniesieniu do sieci drogowej deformacje powierzchni i granicy województwa łódzkiego przedstawiono na rycinie 2.12.

Znacznie większe zniekształcenia są wynikiem przyjęcia odległości kolejowych (rycina 2.13). Przy analizie, jako lokalizacje początkowe, przyjęto te, wyznaczone na podstawie odległości drogowych i jednocześnie wyłączono z badania jednostki nieposiadające dostępu do sieci kolejowej.

Analiza odległości pomiędzy poszczególnymi parami miast województwa łódzkiego pozwoliła również określić maksymalne rozbieżności przy przemieszczaniu się transportem samochodowym, kolejowym i tramwajowym. Porównanie odległości fizycznych i fizycznych rzeczywistych drogowych wskazuje na największe rozbieżności w przypadku relacji Opoczno-Żychlin. Aby dotrzeć z jednego do drugiego miasta, konieczne jest pokonanie odległości o 29,71 km dłuższej niż wskazuje na to linia prosta łącząca obydwa ośrodki. Relację pomiędzy Drzewicą i Kutnem charakteryzuje największy przyrost fizycznej odległości rzeczywistej (w wariancie najszybszym) w stosunku do odległości fizycznej. Rozbieżność ta wynosi $66,18 \mathrm{~km}$. Najbardziej znacząca rozbieżność pomiędzy odległością fizyczną rzeczywistą drogową i jej wariantem ujmującym teoretycznie najszybsze połączenia dotyczy podróży pomiędzy Kutnem a Białą Rawską i wynosi $57,6 \mathrm{~km}$. Zestawienie odległości drogowych (wariant najszybszy) i kolejowych wskazuje maksymalne wydhużenie linii kolejowej pomiędzy Wieluniem i Kutnem - 243,31 km. Odwrotna sytuacja - nadłożenie drogi w stosunku do linii kolejowej - występuje najwyraźniej pomiędzy Rawą Mazowiecką i Sieradzem - 25,09 km lub pomiędzy Biała Rawską i Sieradzem - 26,15 km (przy przyjęciu dojazdu do Białej Rawskiej koleją wąskotorową). Do analizy włączono również sieć tramwajową. Pomiędzy Pabianicami i Konstantynowem Łódzkim linia tramwajowa jest o 12,17 km dłuższa od dróg łączących te miasta. Jest natomiast krótsza o $0,88 \mathrm{~km} \mathrm{w}$ przypadku połączenia Pabianice-Ozorków. Ostatnie porównanie dotyczy odległości w sieci tramwajowej i kolejowej. W przypadku relacji Zgierz-Ozorków, pomiędzy ostatnim i pierwszym przystankiem, poruszając się po linii kolejowej, konieczne jest pokonanie o 13,88 km więcej. Linia tramwajowa jest natomiast dłuższa od linii kolejowej pomiędzy Pabianicami i Zgierzem, a różnica wynosi 7,23 km.

${ }^{19}$ Do sporządzenia map wykorzystano oprogramowanie Darcy 2.0 udostępnione na zasadach open source (http://www.spatial-modelling.info/Darcy-2-module-de-comparaison, 27.10.2013), które dzięki zastosowaniu dwuwymiarowej funkcji regresji pozwala na porównanie dwóch różnych powierzchni określonych przez punkty homologiczne za pomocą współrzędnych XY oraz odpowiadających im współrzędnych X’Y'. 


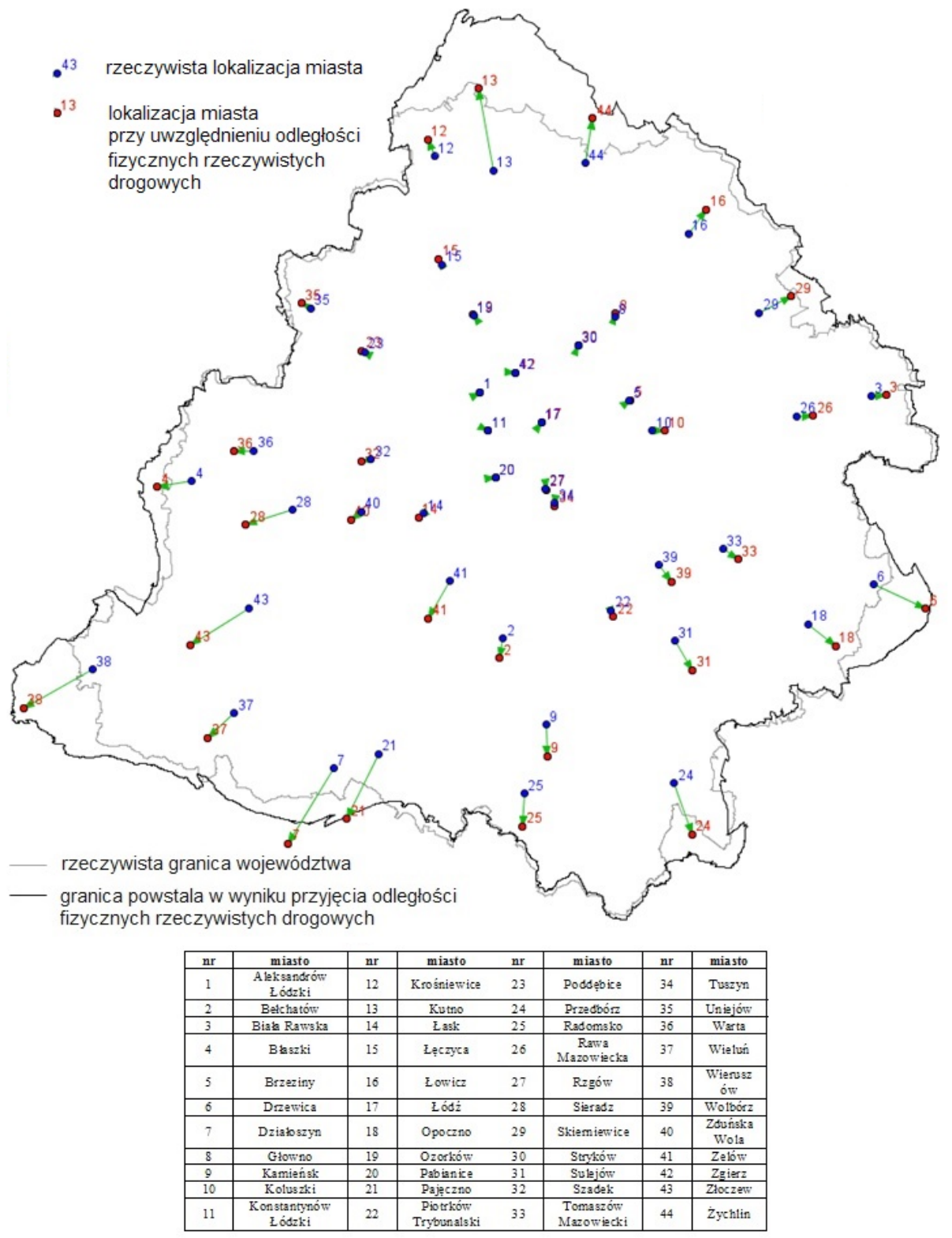

Rycina 2.12. Deformacja granicy województwa łódzkiego w wyniku przyjęcia odległości fizycznych rzeczywistych drogowych do Łodzi Źródło: opracowanie własne 


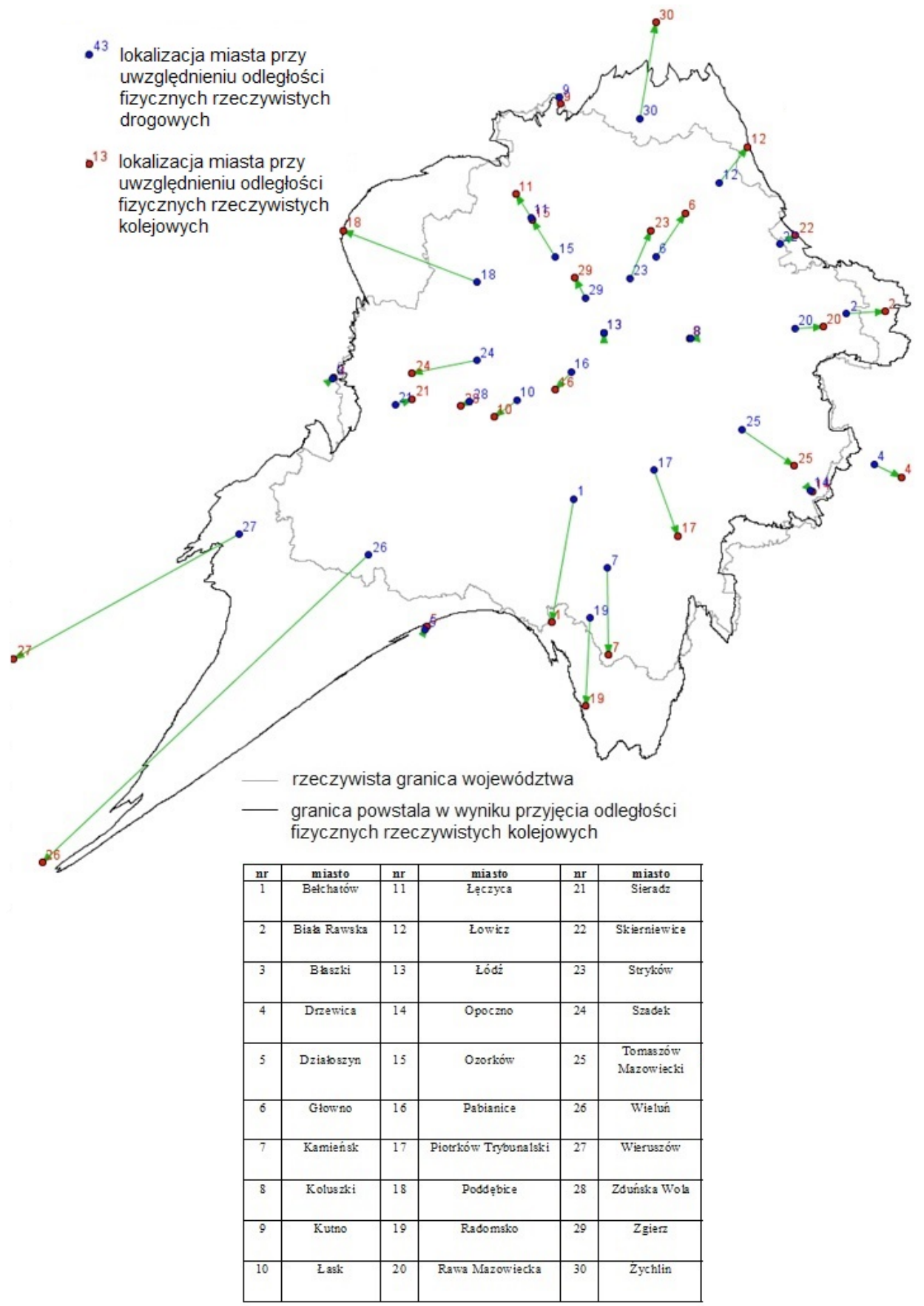

Rycina 2.13. Deformacja granicy województwa łódzkiego w wyniku przyjęcia odległości fizycznych rzeczywistych kolejowych do Łodzi Źródło: opracowanie własne 


\subsubsection{Dostępność potencjałowa}

Jak podaje Śleszyński (2009a), elementarnym warunkiem umożliwiającym powstanie efektów synergicznych w sieci osadniczej danego obszaru są liczne i intensywne połączenia pomiędzy poszczególnymi elementami sieci. W celu zapewnienia efektywności powiązań należy tak kształtować sieci komunikacyjne, aby układ ich poszczególnych elementów zapewniał możliwie najkrótsze powiązanie ośrodków, jednocześnie odznaczając się przygotowaniem na przyjęcie ruchu o określonej wielkości. Kluczowe jest zatem uwzględnienie komponentu użytkowania terenu, np. w postaci oceny atrakcyjności poszczególnych ośrodków jako potencjalnych celów podróży. Tego typu badania umożliwiają zastosowanie analiz grawitacyjnych i potencjałowych, bazujących na naukach fizycznych, ale skutecznie stosowanych od dawna w analizach transportowych ${ }^{20}$. Aby sieci transportowe danego obszaru posiadały korzystny układ, muszą zapewniać połączenia jednostek osadniczych, odwzorowując naturalne ukierunkowania i siłę potencjalnego oddziaływania ich mas. Dobrze funkcjonująca sieć transportowa powinna wyróżniać się wysokim poziomem efektywności przestrzennej. Należy rozumieć ją jako możliwie najkorzystniejszy ekonomicznie przebieg połączeń, umożliwiający maksymalną obsługę na danym obszarze przy jej jak najmniejszej długości. Jedną z metod oceny efektywności systemów transportowych, względem sieci osadniczej danego obszaru, jest porównanie wskaźników dostępności przestrzennej przed i po inwestycji w infrastrukturę transportową. Takie założenia wykorzystano przy konstrukcji opisanego wcześniej międzygałęziowego wskaźnika dostępności transportowej Polski. Jednakże ten sposób postępowania okazuje się w praktyce bardzo skomplikowany oraz natrafia na liczne problemy natury metodologicznej i technicznej. Konieczne jest więc zastosowanie bardziej uproszczonych rozwiązań, które w przystępny sposób, dzięki pewnym uproszczeniom, umożliwią ocenę efektywności systemów transportowych. Dzięki przyjętej metodzie oceny potencjału transportowo-osadniczego zaproponowanej przez Śleszyńskiego (2009b), a zaimplementowanej w niniejszej pracy na grunt województwa łódzkiego, możliwe jest określenie, jaka jest sprawność nowoczesnej sieci drogowej, kolejowej i tramwajowej względem systemu osadniczego. Jednym z najważniejszych założeń przyjętej analizy jest wykorzystanie modelu grawitacji ${ }^{21}$,

${ }^{20}$ Dostępność potencjałowa ma wiele zalet. Metoda ta w znacznie większym stopniu niż dostępność mierzona odległością lub dostępność kumulatywna uwzględnia zależności między komponentem użytkowania przestrzeni a komponentem transportowym. W modelu potencjału atrakcyjność celu podróży maleje wraz z wydłużaniem się odległości między źródłem i celem podróży, co jest zgodne z intuicyjnie wyczuwalną percepcją przestrzeni przez uczestników ruchu (Rosik 2012).

${ }^{21}$ Podstawowa idea modelu grawitacji sprowadza się do założenia, że masa danej jednostki jest zależna od masy innych jednostek w taki sposób, że wpływ ich maleje w miarę oddalania się od siebie. Wzajemne oddziaływanie między dwoma jednostkami jest wówczas wprost proporcjonalne 
znanego z nauk fizycznych, a zastosowanego w naukach społecznych w XIX w. Zależność oddziaływania dwóch ośrodków o określonych masach $M_{1}$ i $M_{2}$ położonych w odległości s wyraża się ogólnym wzorem:

$$
G=\frac{M_{1}^{a} M_{2}^{a}}{s^{b}}
$$

Przy czym w klasycznej formule masy dwóch ośrodków wyrażone są liczbą mieszkańców, a na potrzeby niniejszego badania dokonano obliczenia mas, jako odpowiednio sporządzonego wskaźnika. Wartości mas określono w taki sposób, że najpierw obliczano udział zmiennej wchodzącej w skład wskaźnika dla danego miasta w całej zbiorowości miast województwa łódzkiego, a następnie mnożono go przez odpowiednią wagę (Komornicki i in. 2009). Masy poszczególnych miast służą również do określenia wkładu pozostałych (docelowych) węzłów w jego wskaźnik dostępności. Funkcjonują w charakterze prawdopodobieństwa wystąpienia zdarzenia transportowego $\mathrm{z}$ badanego miasta do miasta docelowego (Komornicki i in. 2008). Wybór zmiennych był arbitralny, natomiast nawiązywał do zbioru zmiennych wykorzystanych przez Komornickiego i in. (2008) na potrzeby opracowania wskaźnika międzygałęziowej dostępności transportowej terytorium Polski. Wybrano 10 zmiennych, dla których przyjęto indywidualne wagi (tabela 2.2).

Dobrane zmienne mają za zadanie obrazować atrakcyjność poszczególnych miast województwa łódzkiego jako potencjalnych źródeł podróży. Źródłem danych był Bank Danych Lokalnych Głównego Urzędu Statystycznego. Odległość pomiędzy $M_{1}$ i $M_{2}$ jest mierzona odległościami fizycznymi rzeczywistymi w sieci drogowej (w wariancie najszybszym), w sieci kolejowej i tramwajowej. Wykładnikowi $a$ przypisano wartość jeden, natomiast $b$ jest kwadratem jak w klasycznym ujęciu. Isard (1954), który po raz pierwszy zastosował ten model w teorii rozwoju regionalnego w latach pięćdziesiątych ubiegłego wieku, przyjął wykładnik równy jedności. Budowa wskaźnika opiera się na następującym algorytmie postępowania: w pierwszej kolejności wyznaczana jest sieć miast województwa łódzkiego, a następnie tworzona jest macierz potencjalnych połączeń transportowych pomiędzy nimi ${ }^{22}$. Dalej na podstawie opisanego wyżej modelu grawitacyjnego obliczane są siły oddziaływań pomiędzy poszczególnymi ośrodkami. Końcowy wskaźnik liczony jest w ten sposób, że istniejące, rzeczywiste - efektywne połączenia drogowe stanowią udział odpowiadających im sił oddziaływań w sumie wszystkich potencjalnych. Maksymalna wartość wskaźnika może wynieść 100\%, tzn. że

do pewnej funkcji iloczynu mas i odwrotnie proporcjonalne do pewnej funkcji odległości. W praktyce jako postacie tych funkcji przyjmuje się najczęściej pewne wyrażenia potęgowe.

${ }^{22}$ Dla każdego miasta istnieje możliwość interakcji z każdym innym, będącym w analizowanej sieci transportowej. Dlatego też zbudowana została macierz długości przejazdu dla linii drogowej, kolejowej i tramwajowej. W przypadku transportu drogowego była to macierz 44 na 44 . Dla innych sieci była odpowiednio mniejsza. 
Tabela 2.2. Zmienne określające atrakcyjność miast

\begin{tabular}{|l|c|}
\hline \multicolumn{1}{|c|}{ Cecha } & Waga \\
\hline Liczba ludności (faktyczne miejsce zamieszkania) & 0,25 \\
\hline Liczba zameldowań i wymeldowań na pobyt stały & 0,10 \\
\hline Liczba osób dojeżdżających do pracy* & 0,15 \\
\hline Liczba podmiotów gospodarczych & 0,10 \\
\hline Ranga administracyjna** & 0,15 \\
\hline Liczba placówek opieki zdrowotnej & 0,05 \\
\hline Liczba szkół policealnych & 0,05 \\
\hline Liczba pokoi w hotelach & 0,05 \\
\hline Liczba kin stałych & 0,05 \\
\hline Liczba targowisk sezonowych i stałych & 0,05 \\
\hline
\end{tabular}

* Pytanie dotyczące skali i kierunków dojazdów do pracy w Polsce zostało zawarte w spisie powszechnym z 2011 r. Natomiast rezultaty spisu w części im poświęconej nie zostały opublikowane w czasie niniejszego badania i nie udostępniono ich na prośbę autora. Dlatego też wykorzystano dane dotyczące przepływów ludności związanych z zatrudnieniem w Polsce w 2006 r. (http://www.stat.gov.pl/gus/5840_13474_PLK_HTML.htm, 10.11.2014). Źródłem informacji służących oszacowaniu skali i kierunków przepływu ludności były zbiory systemu podatkowego urzędów skarbowych za rok 2006, gromadzone w bazie POLTAX (PIT - 11/8B oraz PIT-40), dotyczące osób, dla których gmina zamieszkania była inna niż gmina miejsca pracy z jednoczesną informacją o zwiększonych kosztach uzyskania przychodu z tytułu dojazdów do pracy. Pewne wątpliwości może budzić fakt, iż wykazywane w formularzach PIT miejsca zamieszkania nie muszą pokrywać się z rzeczywistym źródłem podróży. W przypadku bazy POLTAX jest prawdopodobne, że dla pewnej części pracowników miejsce zamieszkania podawane w deklaracjach podatkowych nie było głównym miejscem zamieszkania. Niemniej, mimo tej wady, dane GUS o dojazdach do pracy, w układzie macierzowym, pozwalają na szczegółową analizę natężenia oraz kierunków dojazdów do pracy pomiędzy gminami w Polsce (Rosik 2012).

** Ze względu na brak możliwości bezwzględnego skwantyfikowania tej zmiennej konieczne było przyjęcie wartości oznaczających jednostki „wagi”. Adaptując metodą wypracowaną przez Komornickiego i in. (2008), określono następujące wagi: stolica województwa - 60, stolice „starych województw" - 20, ośrodki powiatowe - 10 oraz ośrodki gminne - 5 .

Źródło: opracowanie własne na podstawie danych BDL GUS.

z jednego ośrodka do wszystkich innych będzie możliwe dotarcie drogami o określonych paramentach. Istnieje zatem możliwość określenia efektywności transportowej dowolnej kategorii miast - wojewódzkich, powiatowych lub wybranej kategorii z innymi, np. stolicy kraju z miastami kolejnych szczebli hierarchicznych w strukturze administracyjno-osadniczej. Do analiz przedstawionych w niniejszej pracy wybrano zbiór 44 miast województwa łódzkiego. Obliczenia sił oddziaływań dokonano na podstawie przedstawionego wcześniej wskaźnika. Połączenia efektywne ustalono jako te, dla których odległości fizyczne rzeczywiste (drogowe, kolejowe czy tramwajowe) nie przekraczają 120\% odległości fizycznych pomiędzy określoną parą miast. W ten sposób nie były uwzględniane teo- 
retycznie możliwe, choć w praktyce niewykorzystane okrężne połączenia (Śleszyński 2009b). Trzeba również pamiętać, że do analizy (w przypadku transportu drogowego) włączono odległości dla tras umożliwiających teoretycznie najkrótszy czas przejazdu, a w rzeczywistości transport nie odbywa się tylko po drogach określonych kategorii i nie zawsze czas dojazdu jest priorytetem dla użytkownika.

Pod względem poziomu efektywności transportowo-osadniczej w sieci drogowej województwa łódzkiego wyraźnie dominującym ośrodkiem jest Łódź.

Masa ośrodka, wyrażona syntetycznym wskaźnikiem, ponad siedmiokrotnie przewyższa masę drugiego w kolejności Piotrkowa Trybunalskiego i ponad stukrotnie, ostatnie pod tym względem, Błaszki. Potencjał Łodzi wynikający z oddziaływania pozostałych 43 miast województwa, połączonych siecią dróg (w wariancie najszybszym), potwierdza jej dominującą rolę w województwie (rycina 2.14).

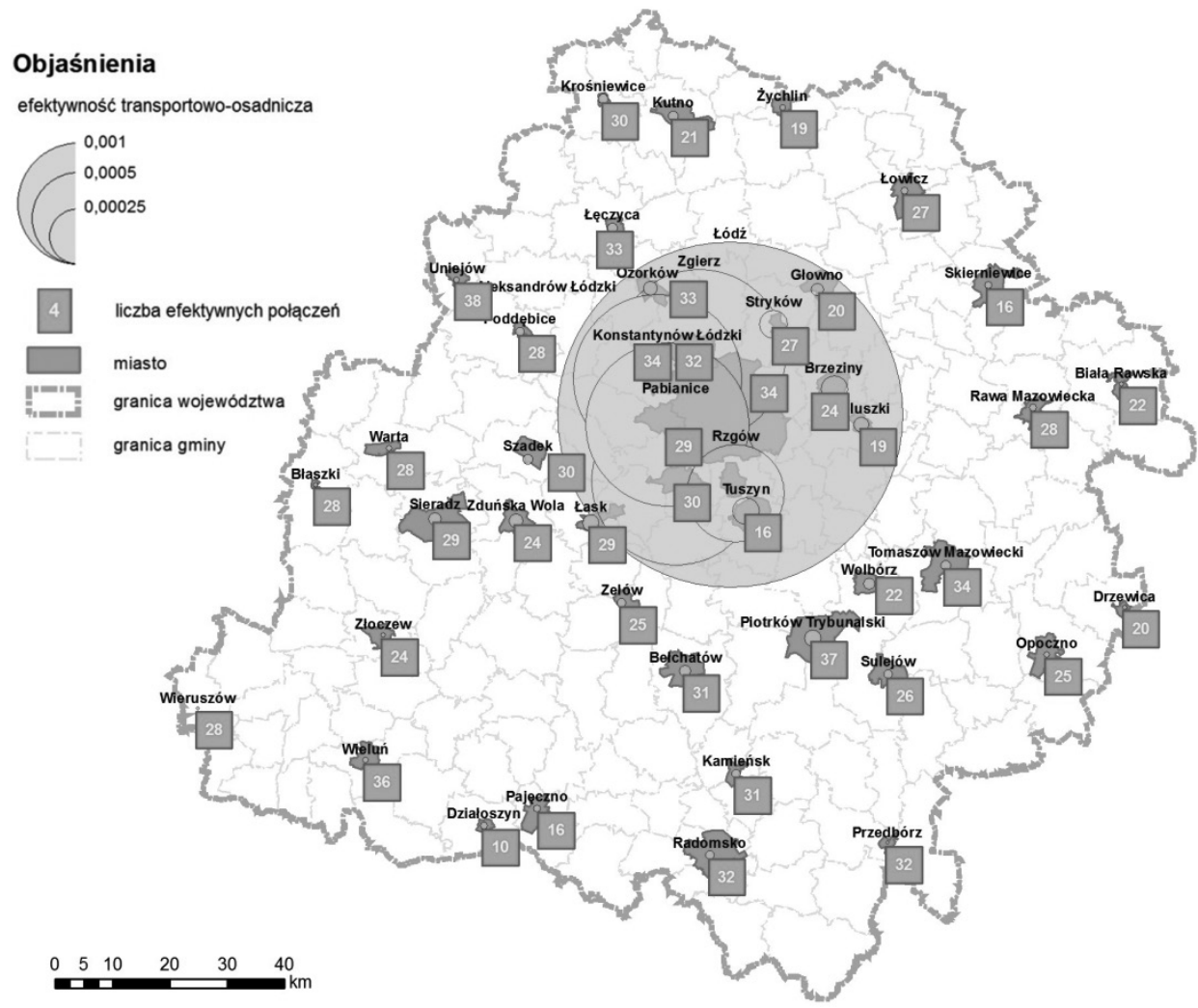

Rycina 2.14. Potencjał transportowo-osadniczy oraz liczba efektywnych połączeń w sieci drogowej do miast województwa łódzkiego

Źródło: opracowanie własne 
Jednakże przewaga nad drugim w tym przypadku Zgierzem zmniejszyła się do czterokrotnej. Cztery kolejne pozycje zajmują: Aleksandrów Łódzki, Pabianice, Konstantynów Łódzki i Rzgów, co dobitnie wskazuje na dominującą siłę Łodzi. Nawet przy niedużych odległościach jednostki o małej atrakcyjności (np. Rzgów) mogą osiągnąć wysoki potencjał. Rzgów jest też ostatnim w powyższej klasyfikacji ośrodkiem, którego potencjał względem miasta poprzedzającego w klasyfikacji waha się w zakresie od 1 do 4 . Potencjał kolejnego z miast - Strykowa - jest już dwunastokrotnie niższy niż Rzgowa. Należy również podkreślić wagę oporu przestrzeni, który pomimo dużej liczby efektywnych połączeń ośrodków o wysokiej atrakcyjności (np. Piotrków Trybunalski) determinuje ich niski potencjał. Najliczniejszą grupę połączeń efektywnych posiada Uniejów (38), jednakże ze względu na swoje położenie w sieci drogowej i oddalenie od Łodzi nie osiąga wysokiego poziomu potencjału transportowo-osadniczego. Podobnie wysoką ilość połączeń efektywnych posiada wspomniany Piotrków Trybunalski (37) oraz Wielun (36). Poniżej 20 drogowych połączeń efektywnych ma pięć miast województwa - Żychlin, Koluszki, Pajęczno, Tuszyn, Skierniewice i najgorszy pod tym względem Działoszyn z wyłącznie 10 połączeniami.

Poza samą wielkością potencjału transportowo-osadniczego istotne znaczenie ma stopień jego wykorzystania, a przede wszystkim potencjał pozostały do zagospodarowania (rycina 2.15). Dwanaście miast województwa łódzkiego wykorzystuje dostępny im potencjał w ponad $95 \%$. Najlepiej istniejące szanse wykorzystane są w przypadku Aleksandrowa Łódzkiego. Łódź, jako ośrodek najbardziej atrakcyjny, swojego potencjału nie wykorzystuje w niespełna $8 \%$.

Wykorzystanie potencjału na poziomie poniżej $75 \%$ występuje jedynie w przypadku sześciu miast: Skierniewic, Złoczewa, Zelowa, Żychlina, Koluszek i Rzgowa. Tak wysokie wartości procentowe należy przyjmować za oznakę efektywnie działającej sieci drogowej. Wszelkiego rodzaju działania nastawione na sieć drogową, a mające na celu poprawę skomunikowania wzajemnego miast województwa, mogą przyczynić się jedynie do wzrostu wykorzystania potencjału w zakresie $25 \%$, a w przypadku pierwszej wymienionej grupy miast w zakresie $5 \%$. Bardzo niski udział potencjału istniejącego w przypadku Rzgowa (6\%) wynika przede wszystkim z nieefektywnego połączenia z Łodzią. Miasta dzieli mała odległość fizyczna, a łącząca je droga nieznacznie przekracza 120\% tego odcinka. Potwierdza to bardzo istotną rolę Łodzi i jej oddziaływania na jednostki zlokalizowane w jej bezpośrednim sąsiedztwie.

Potencjał transportowo-osadniczy miast województwa łódzkiego w świetle sieci kolejowej prezentuje się z oczywistych względów wyraźnie odmiennie (rycina 2.16). Wynika to przede wszystkim z mniejszej liczby miast posiadających dostęp do linii kolejowej oraz układu sieci kolejowej pozbawionej połączeń o charakterze diagonalnym. Skutkuje to dużymi różnicami pomiędzy odległościami fizycznymi i odległościami fizycznymi rzeczywistymi, co zwiększa opór przestrzeni. 


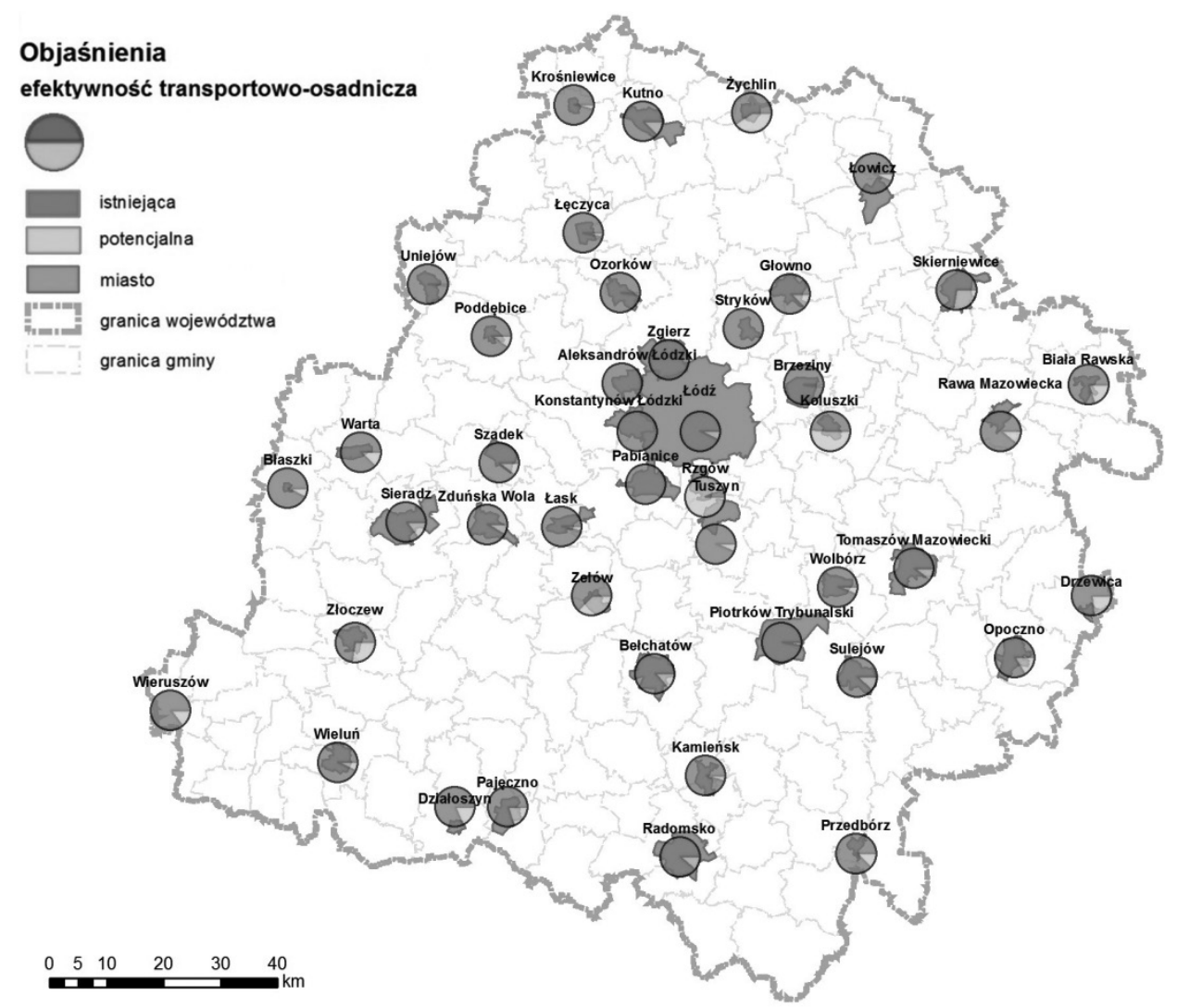

Rycina 2.15. Struktura potencjału transportowo-osadniczego miast województwa łódzkiego w sieci drogowej

Źródło: opracowanie własne

Ponownie największy potencjał spośród 30 miast połączonych siecią kolejową ma Łódź. Jednakże jej potencjał jest tylko nieco ponad dwukrotnie wyższy od drugiego w tej klasyfikacji Zgierza. Trzecim miastem pod tym względem są Pabianice. Te trzy ośrodki dość wyraźnie odróżniają się od pozostałych, ponieważ czwarte Koluszki posiadają potencjał ponad pięciokrotnie niższy od Pabianic. Najniższym potencjałem odznacza się Wieruszów, którego dystans do Łodzi jest czterokrotnie większy niż dystans dzielący pierwsze i ostatnie miejsce w przypadku sieci drogowej. Ilość efektywnych połączeń w sieci kolejowej również znacząco różni się od sieci drogowej. Spośród 29 możliwych połączeń, maksymalną ilość (zaledwie 11) osiągają Błaszki. Dziesięć efektywnych połączeń posiadają Poddębice. W przypadku czterech miast (Tomaszów Mazowiecki, Bełchatów, Wieluń, Wieruszów) efektywne połączenia nie występują. 


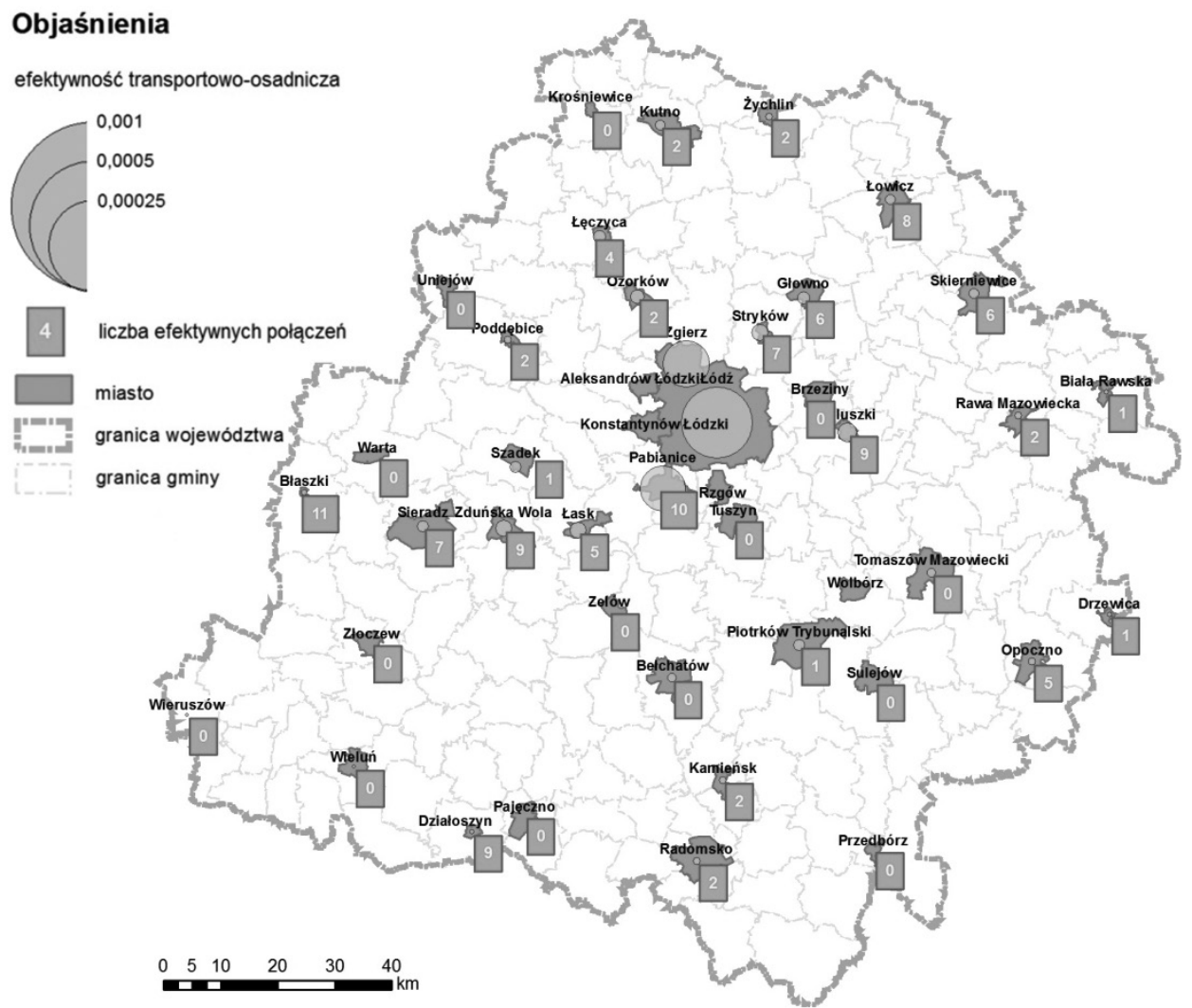

Rycina 2.16. Potencjał transportowo-osadniczy oraz liczba efektywnych połączeń w sieci kolejowej do miast województwa łódzkiego

Źródło: opracowanie własne

Znacznie ograniczona ilość połączeń efektywnych implikuje niskie udziały wykorzystanego potencjału transportowo-osadniczego (rycina 2.17). Jedynie w przypadku Koluszek potencjał wykorzystany jest na poziomie prawie $90 \%$. Błaszki i Opoczno posiadają potencjał, którego wykorzystanie wynosi około $50 \%$. Duże znaczenie ma tutaj nie sama ilość efektywnych połączeń, ale przede wszystkim to, z jak ,silnym” ośrodkiem takie połączenie występuje. Poza miastami, które nie wykorzystują swojego potencjału transportowo-osadniczego w wyniku braku efektywnych połączeń, najniższy poziom wykorzystania potencjału dotyczy Szadku (0,4\%), pomimo jego siedmiu efektywnych połączeń.

Taka sytuacja pozwala wnioskować, że istnieje znaczna ilość niewykorzystanego potencjału, który mógłby zostać zagospodarowany dzięki inwestycjom w zakresie tworzenia nowych linii pomiędzy miastami województwa łódzkiego. Biorąc pod uwagę plany inwestycyjne PKP PLK S.A., poziom wykorzystania po- 


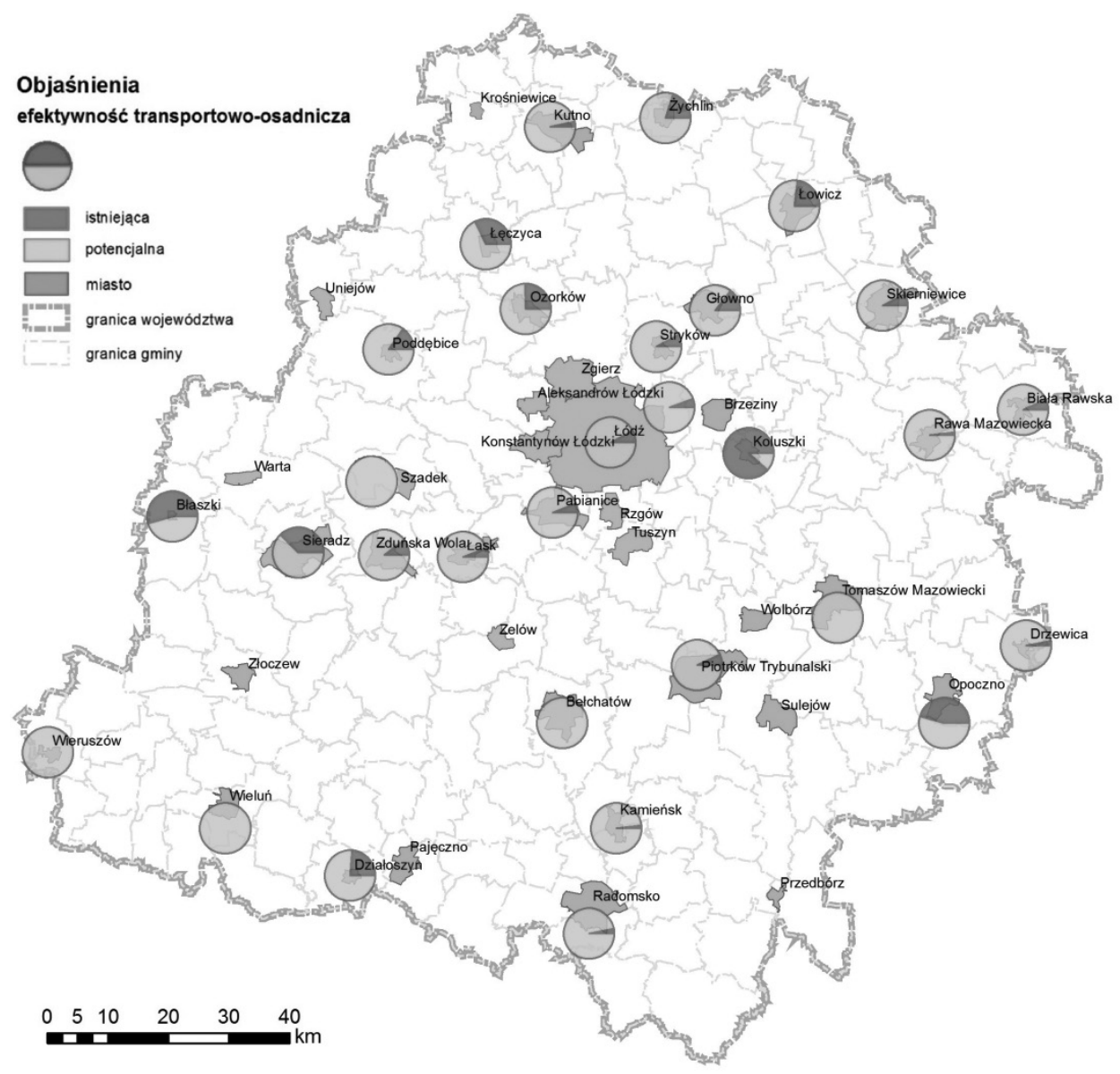

Rycina 2.17. Struktura potencjału transportowo-osadniczego miast województwa łódzkiego w sieci kolejowej

Źródło: opracowanie własne

tencjału transportowo-osadniczego się nie zwiększy. Również realizacja KDP nie wpłynie na wykorzystanie potencjału w ujęciu regionalnym ze względu na jej ponadregionalny charakter, który nie wpisuje się w wojewódzką sieć połączeń.

Łódź wyróżnia się wysokim potencjałem również w sieci tramwajowej. Natomiast jest on prawie o $60 \%$ większy od potencjału Zgierza, który zajmuje w tej klasyfikacji drugie miejsce. Trzeci pod względem wielkości potencjału jest Konstantynów Łódzki, który jest jednak prawie trzykrotnie mniejszy od łódzkiego. Czwartym miastem pod względem wielkości potencjału są Pabianice. Najmniejszy potencjał ma Ozorków, który stanowi jednie $0,12 \%$ potencjału Łodzi. Przy za- 
łożeniu pomiarów odległości fizycznych do granic miasta, a fizycznych rzeczywistych dla transportu tramwajowego do najbliższego przystanku w granicach miasta, efektywne połączenia tramwajowe występują pomiędzy: Łodzią i Ozorkowem, Pabianicami i Ozorkowem oraz Zgierzem i Ozorkowem. Implikuje to wykorzystanie potencjału przez Ozorków na poziomie niemalże 99\%. Dla pozostałych miast udział wykorzystanego potencjału nie przekracza $1 \%$.

$\mathrm{Na}$ podstawie sporządzonej macierzy powiązań wydzielić można również grupy miast na zasadzie największego ciążenia przestrzennego. W tym celu możliwe jest nawiązanie do teorii grafów. Dla każdego miasta znaleźć można kilka innych, z którymi łączą je najsilniejsze powiązania (rycina 2.18).

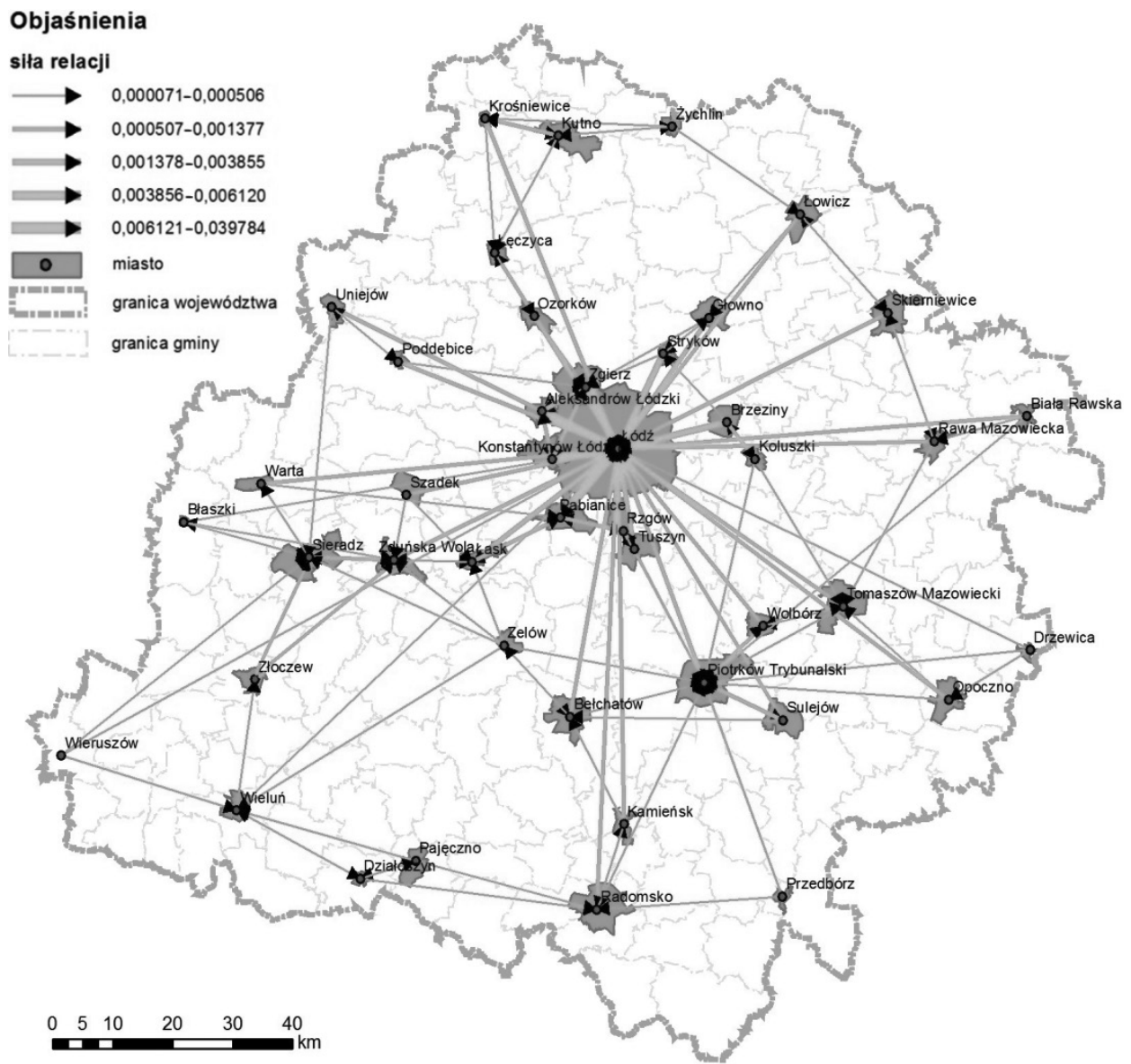

Rycina 2.18. Siła i kierunek oddziaływania relacji transportowo-osadniczych I, II i III rzędu (sieć drogowa)

Źródło: opracowanie własne 
Przyjęto założenie, że z każdego wiersza macierzy powiązań wydzielone zostaną trzy najwyższe wartości, co jest równoznaczne z ustaleniem dla każdej, rozpatrywanej jednostki - trzech innych, z którymi posiada ona najsilniejsze powiązania grawitacyjne. Uwzględniono najwyższe powiązania między poszczególnymi jednostkami przestrzennymi (I, II i III stopień powiązań grawitacyjnych) oraz odwzorowano istniejące współzależności w postaci grafu. W tym celu każde miasto rozpatrywano jako wierzchołek grafu, w którym łukami były odpowiednio skierowane odcinki, łączące korespondujące ze sobą wierzchołki (szczegółowe wyjaśnienie metod grafowych znajduje się w dalszej części niniejszego podrozdziału).

W przypadku sieci drogowej wśród najsilniejszych powiązań grawitacyjnych dominują te skierowane do Łodzi, Piotrkowa Trybunalskiego oraz Zgierza, Zduńskiej Woli i Sieradza. Dotyczy ich najliczniejsza grupa najsilniejszych relacji bilateralnych. Występuje również grupa miast (Wieruszów, Przedbórz, Drzewica, Szadek, Biała Rawska), które są na tyle „słabo atrakcyjną” destynacją, że żadne z pozostałych miast województwa nie łączą z nim najsilniejsze powiązania. Widoczne jest także pewne podobieństwo pomiędzy układem krawędzi odpowiadających relacjom między parami miast a realnie funkcjonują siecią drogową województwa.

W przypadku sieci kolejowej najsilniejsze powiązania skierowane są do Łodzi, Koluszek, Pabianic, Zgierza i Sieradza (rycina 2.19).

Najmocniejsza relacja dotyczy Łodzi i Koluszek. Jest to zależność ponad czterokrotnie silniejsza od drugiej pod tym względem relacji pomiędzy Pabianicami a Zgierzem. Występuje również grupa miast niepowiązanych relacjami, co wynika z braku efektywnych połączeń (Tomaszów Mazowiecki, Bełchatów, Wieluń, Wieruszów). Niska atrakcyjność Radomska, Szadku, Kamieńska, Drzewicy, Rawy Mazowieckiej oraz Kutna powoduje, że żadne z pozostałych miast województwa nie łączą z nim powiązania I, II ani III rzędu. Podobnie jak w przypadku sieci drogowej, również krawędzie obrazujące relacje w sieci kolejowej nawiązują do realnie funkcjonującej sieci kolejowej. W przypadku sieci tramwajowej spośród relacji opartych na efektywnych połączeniach najsilniejsze oddziaływanie występuje pomiędzy Łodzią i Ozorkowem. Druga pod względem siły jest relacja łącząca Zgierz z Ozorkowem. Najsłabsza relacja dotyczy Pabianic i Ozorkowa. Brak innych relacji jest wynikiem nieefektywności pozostałych połączeń.

W ramach wymienionych grup miast silne powiązania grawitacyjne niekoniecznie muszą zachodzić między każdą parą jednostek przestrzennych. Najczęściej elementem wiążącym poszczególne grupy miast połączone najsilniejszymi relacjami jest wspólny, lokalny ośrodek ciążeń, którego rolę pełni w przypadku każdej z sieci Łódź (Kudłacz 1981). 


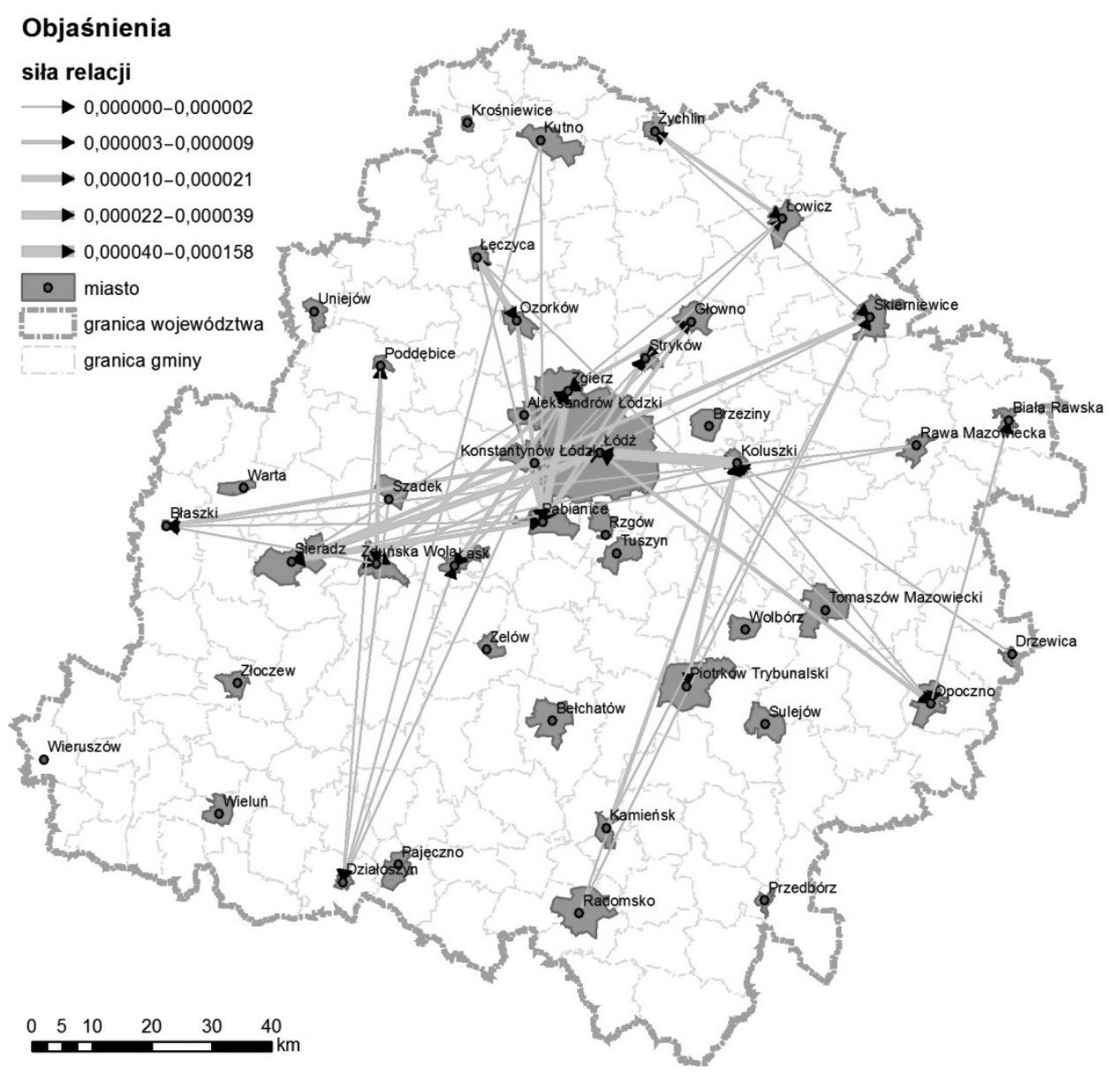

Rycina 2.19. Siła i kierunek oddziaływania relacji transportowo-osadniczych I, II, III rzędu (sieć kolejowa)

Źródło: opracowanie własne

\subsubsection{Analizy grafowe}

W ujęciu fizycznym sieć transportową można postrzegać jako zbiór węzłów, które pozwalają na rozprzestrzenianie się strumieni ruchu. Zbiór węzłów jest dodatkowo wyposażony w urządzenia techniczne, które umożliwiają i ułatwiają ruch (tunele, wiadukty, mosty, systemy sygnalizacji, stacje, urządzenia rozładunkowe, skrzyżowania wielopoziomowe, a przede wszystkim różnej klasy drogi, linie kolejowe i tramwajowe). Tak postrzegana sieć transportowa może zostać 
przedstawiona jako graf ${ }^{23}$ fizyczny będący schematem technicznym sieci. Jeżeli graf fizyczny podda się generalizacji do postaci, w której jako węzły występują tylko stacje pasażerskie i towarowe, a jako krawędzie występują tylko drogi lub linie kolejowe czy tramwajowe łączące węzły i zlokalizuje się tak zgeneralizowany graf na mapie, to powstaje graf geograficzny. Pozwala on na sformułowanie zagadnień dotyczących $\mathrm{np}$. wyboru położenia geograficznego fizycznych węzłów sieci, wyboru położenia geograficznego dróg je łączących czy optymalnego zakresu przepustowości tych dróg. Ponadto umożliwia charakterystykę sieci pod względem klasy dróg pomiędzy poszczególnymi miastami, ich przepustowość czy czasy przejazdów (Ratajczak 1980).

Ze względu na wysoką użyteczność poznawczą i metodologiczną, metody grafowe zostały wykorzystane w szeregu dyscyplinach naukowych (m.in. geografii) na potrzeby analizy różnorodnych struktur. Na polu geografii metody grafowe znalazły również szerokie zastosowanie w analizach struktur sieci transportowych (oraz powiązań w zakresie innych elementów infrastruktury technicznej i społecznej), powiązań ludnościowych, powiązań gospodarczych, czy też w charakterystyce struktury funkcjonalnej obszaru ${ }^{24}$. Na każdej wymienionej płaszczyźnie uwidacznia się najważniejsza zaleta analiz grafowych, a więc możliwość zgeneralizowania określonej struktury zjawiska do możliwie prostej postaci. Wyróżnione są jedynie najważniejsze elementy owej struktury, czyli węzły oraz powiązania między nimi, czyli krawędzie. Taki sposób przedstawienia rzeczywistości, który eliminuje zbędne z punktu celu badania elementy, jest szczególnie użyteczny w niniejszej pracy, pozwalając na równoczesną analizę poprzez zastosowanie różnorodnych miar topologicznych (Ratajczak 1980).

Podstawowym wymogiem analiz topologicznych jest prezentacja rzeczywistej sieci transportowej w formie abstrakcyjnego zbioru punktów (węzłów, wierzchołków ${ }^{25}$ ) połączonych zbiorem linii (odcinków, krawędzi ${ }^{26}$, łuków ${ }^{27}$ ). Podejście grafowe podkreśla układ połączeń pomiędzy węzłami, pomijając informacje na

${ }^{23} \mathrm{Graf}$ - to taka uporządkowana para $(x, \Gamma)$, gdzie $x$ jest nie pustym zbiorem, a $\Gamma$ jest odwzorowaniem $x \mathrm{w} X$. Parą uporządkowaną $<x, \Gamma$, utworzoną z elementów $x, \Gamma$, nazywamy taką parę, w której istotna jest kolejność elementów. Pierwszy z elementów pary $x$ nazywa się poprzednikiem, a $\Gamma$ następnikiem. Odwzorowaniem nazywamy zasadę określającą przyporządkowanie między elementami zbiorów (Potrykowski, Taylor 1982).

${ }^{24}$ Poza analizą struktur sieci transportowych, metody grafowe były szeroko stosowane również przy badaniach zmian morfologii siedlisk, w regionalizacji i hierarchizacji ośrodków, czy przy analizach przepływów w sieciach (Taylor 1974).

${ }^{25}$ Każdy element niepustego zbioru $X$ nazywamy punktem lub wierzchołkiem grafu (Taylor 1980).

${ }^{26}$ Nieuporządkowaną parę wierzchołków $\{x, y\}$, taką że $(x, y)$ należy do $U$ albo $(y, x)$ należy do $U$, nazywamy krawędzią. Zatem krawędź różni się od łuku tym, że w przypadku pierwszym skierowanie nie jest istotne, podczas gdy w ostatnim jest ono podane (Runge 2007).

${ }^{27}$ Uporządkowaną parę elementów $(x, y)$ taką, że $y$ należy do $\Gamma x$, nazywamy łukiem. Zbiór wszystkich łuków grafu oznaczamy $U$ (Taylor 1980). 


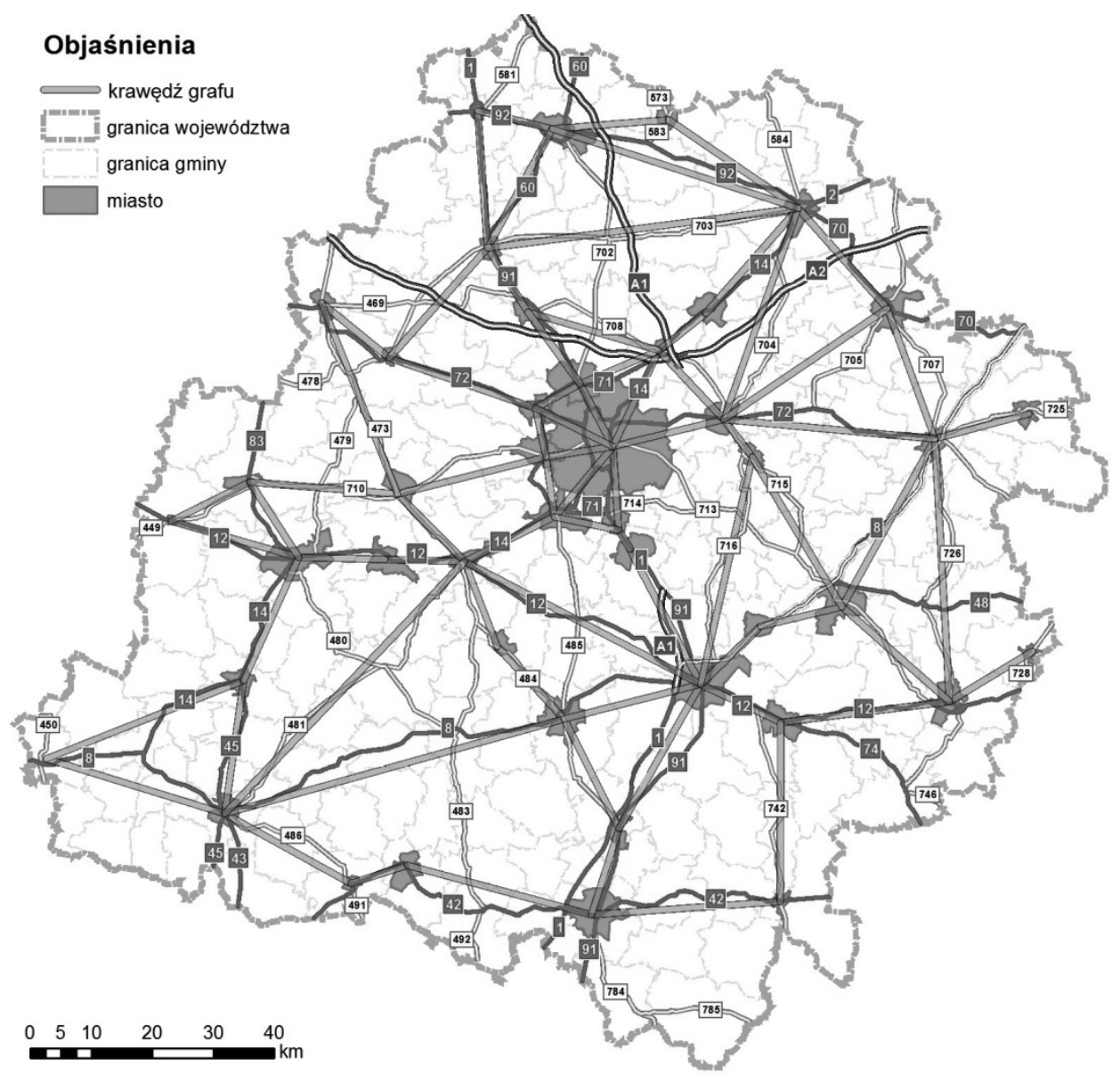

Rycina 2.20. Graf na tle sieci drogowej województwa łódzkiego Źródło: opracowanie własne

temat odległości metrycznych. Sieć transportową (drogową, kolejową i tramwajową) obszaru województwa łódzkiego przedstawiono w postaci skończonego ${ }^{28}$ grafu płaskiego ${ }^{29}$ nieskierowanego ${ }^{30}$.

Stopień, w jakim graf jest uproszczeniem rzeczywistych sieci transportowych, można zaobserwować na rycinie 2.20 dla sieci drogowej i na rycinie 2.21 dla sieci kolejowej. Główna różnica polega na zastąpieniu rzeczywistego prze-

${ }^{28}$ Zbiór wierzchołków - miast - jest skończony.

${ }^{29}$ Graf płaski to taki, którego łuki lub krawędzie nie mają punktów wspólnych prócz wierzchołków.

${ }^{30}$ Krawędzie nie wyrażają kierunku oddziaływania. 
biegu połączeń liniami prostymi. Natomiast wzajemne położenie węzłów pozostaje bez zmian. Przy budowie grafu przyjęto pewne założenia wstępne. Krawędzie grafu odwzorowują jedynie drogi wojewódzkie i krajowe w województwie łódzkim. W przypadku dróg alternatywnych - substytucyjnych - pomiędzy miastami odrzucono te, które w rzeczywistości przekraczają 120\% długości trasy najkrótszej lub są niższej kategorii. W przypadku gdy krawędzie grafu krzyżowałyby się, wybrano drogę o wyższej kategorii (jeśli drogi są takich samych kategorii, krawędzie poprowadzono zgodnie z przebiegiem dróg, które są bliższe odległości fizycznej pomiędzy miastami), aby możliwe było utworzenie grafu płaskiego.

W przypadku grafu obrazującego sieć kolejową włączono pięć wierzchołków (miast) pozostających poza granicami województwa łódzkiego: Kalisz, Ostrów Wielkopolski, Ostrzeszów, Kępno oraz Częstochowę. Poszerzenie grafu o powyższe wierzchołki wynikało z konieczności włączenia Wieruszowa i Wielunia do analizy. Połączenie tychże miast zarówno od strony Częstochowy, jak i Ostrowa Mazowieckiego wynika z analizy rzeczywistych połączeń do Wielunia i Wierusza z pozostałych miast województwa łódzkiego.

Graf ilustrujący sieć tramwajową składa się z czterech krawędzi (łączących Pabianice z Łodzią, Konstantynów Łódzki z Łodzią, Zgierz z Łodzią oraz Ozorków ze Zgierzem) oraz pięciu wierzchołków.

W analizie grafowej szczególne znaczenie mają miary odnoszące się do spójności grafu oraz dostępności poszczególnych węzłów. Reasumując wyniki powyższych wskaźników, należy podkreślić, iż wyraźnie najbardziej spójnym i złożonym jest graf przedstawiający sieć drogową województwa. Ze względu jednak na dużą liczbę wierzchołów (miast) wymaga największej liczby uzupełnień. Mniejszą spójnością i złożonością odznacza się graf prezentujący sieć kolejową. Natomiast graf przedstawiający sieć tramwajową jest grafem niespójnym o zdecydowanie najniższym poziomie złożoności.

Nawiązanie do długości drogi i łańcucha w grafie znalazło również zastosowanie w budowie miar dostępności węzłów w sieci. Podejście topologiczne umożliwia korzystanie z zapisu macierzowego. Jak już wspomniano, stosując zapis zero-jedynkowy, relacje między węzłami w sieci można przedstawić w formie syntetycznej macierzy połączeń. Najbardziej interesująca - z punktu widzenia niniejszej pracy - jest dostępność topologiczna rozumiana jako suma oddaleń z danego węzła do wszystkich pozostałych węzłów w sieci. Główną zaletą tej miary jest jej kompleksowość. Wierzchołek, dla którego liczba asocjacji ${ }^{31}$ jest skończona i najmniejsza ze względu na wszystkie wierzchołki, stanowi punkt centralny grafu. Graf może nie mieć żadnego punktu centralnego lub też mieć ich wiele ${ }^{32}$.

${ }^{31}$ Liczba asocjacji wierzchołka jest to największe oddalenie z danego wierzchołka do wszystkich pozostałych.

${ }^{32}$ Aby jednoznacznie określić węzeł centralny, należy posłużyć się zaproponowaną przez Stutza (1973) względną dostępność topologiczną $(\Omega)$. Przyjmuje ona postać: $\Omega=\frac{A y-A}{A *-A} \cdot 100$, gdzie: 


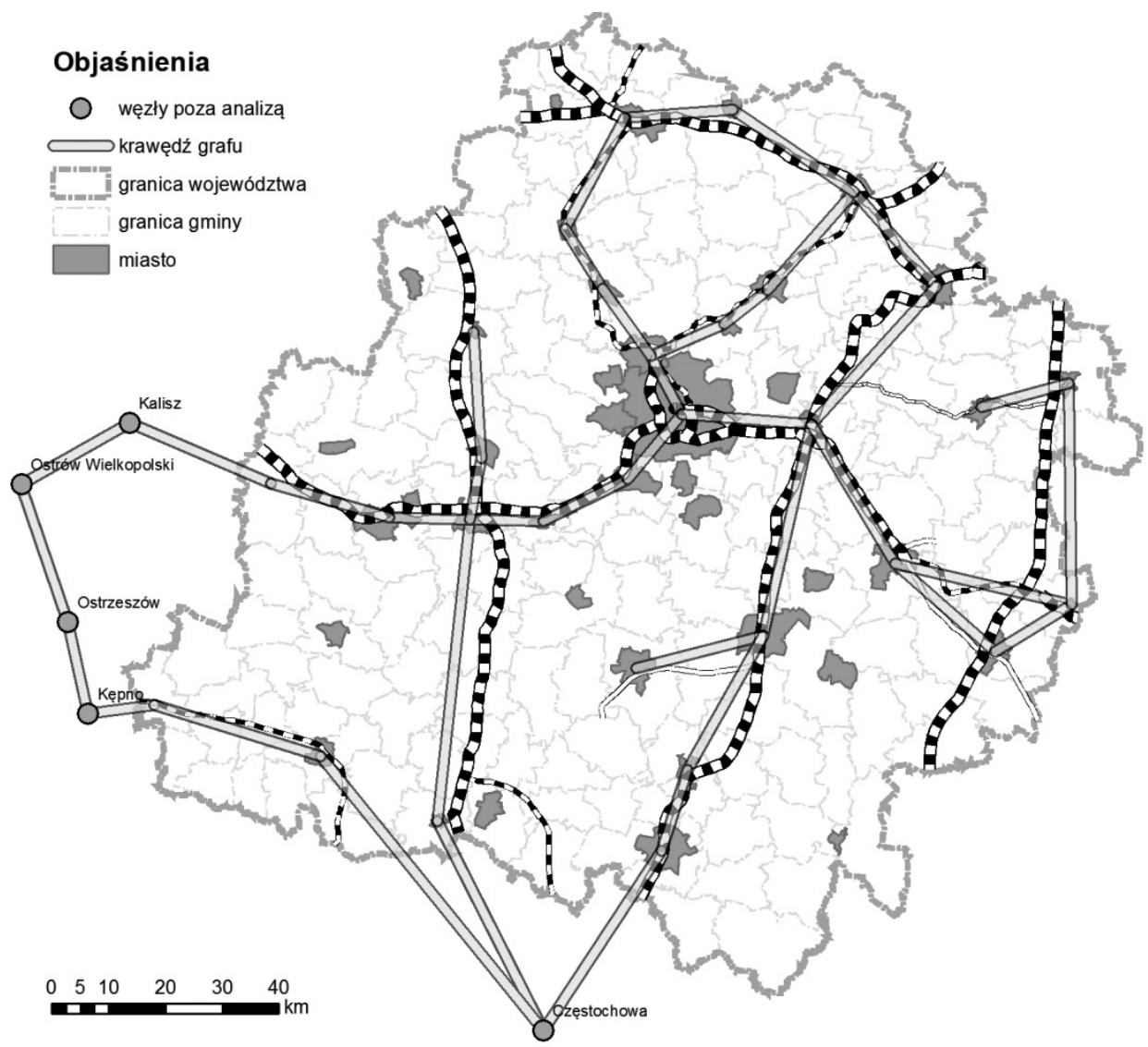

Rycina 2.21. Graf na tle sieci kolejowej województwa łódzkiego

Źródło: opracowanie własne

Wierzchołki, początkowy i końcowy dla średnicy grafu, można określić mianem węzłów peryferyjnych. Shimbel (1953) wprowadził ponadto dyspersję grafu, która jest sumą wskaźników dostępności. Dostępność topologiczna umożliwia wprowadzenie kolejnego wskaźnika, tj. przeciętnej długości drogi. Jest to iloraz dostępności topologicznej i liczby wierzchołków.

Na rycinie 2.22 przedstawiono graficznie przestrzenne zróżnicowanie dostępności topologicznej węzłów (miast) województwa łódzkiego w świetle sieci drogowej.

$A y$ - dostępność topologiczna rozpatrywanego węzła, $A^{*}$ - maksymalna wartość dostępności (węzeł najbardziej niedostępny), $A$ - minimalna wartość dostępności (węzeł najbardziej dostępny).Węzeł, którego względna dostępność topologiczna jest najbliższa zeru, uważany jest za punkt centralny (Potrykowski, Taylor 1982). 


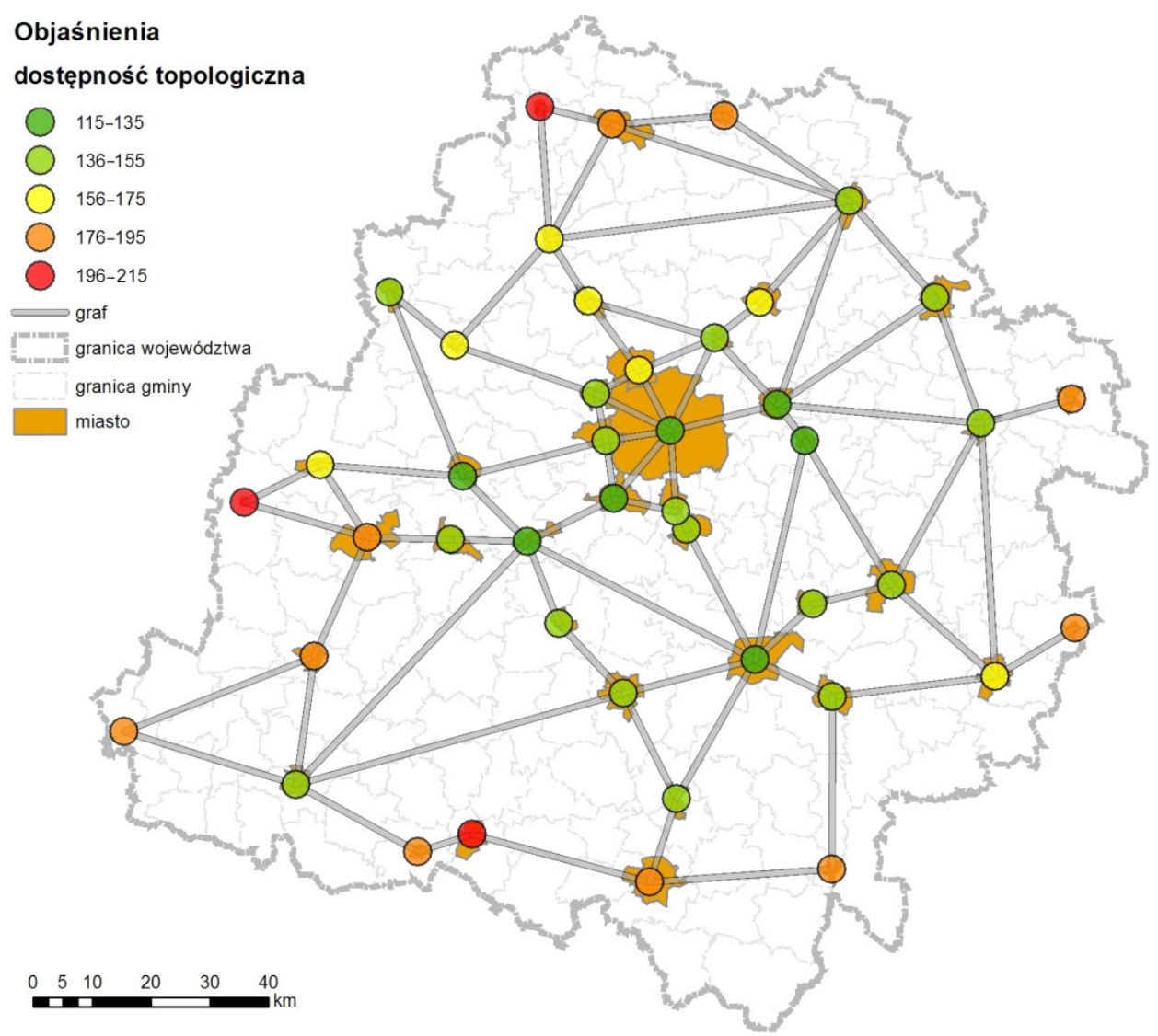

Rycina 2.22. Przestrzenne zróżnicowanie dostępności topologicznej miast województwa łódzkiego w sieci drogowej

Źródło: opracowanie własne

Charakterystyczne jest skupienie węzłów najbardziej dostępnych w centrum sieci i stopniowe zmniejszanie się dostępności wraz z oddalaniem od niego. Najwyższymi poziomami dostępności odznaczają się: Szadek (132), Pabianice (127), Łódź (126), Koluszki (125), Brzeziny (123), Łask (120) oraz Piotrków Trybunalski, którego liczba asocjacji ze względu na wszystkie pozostałe miasta jest najmniejsza (118) i tym samym jest on punktem centralnym grafu. Najniższym poziomem dostępności charakteryzują się: Pajęczno (197), Błaszki (198) i Krośniewice (202), które są węzłami najgorzej dostępnym. Dyspersja grafu przedstawiającego sieć drogową województwa łódzkiego wynosi 6964, a przeciętna długość drogi stanowi 3,6.

W przypadku sieci kolejowej przestrzenne zróżnicowanie dostępności topologicznej węzłów (miast) (rycina 2.23) nie zmienia się wraz z odległością od geo- 
metrycznego centrum tak wyraźnie jak w odniesieniu do sieci drogowej. Wynika to z przebiegu krawędzi grafu, które nie nawiązują do układu promienistego, mającego swoje centrum w Łodzi.

\section{Objaśnienia}

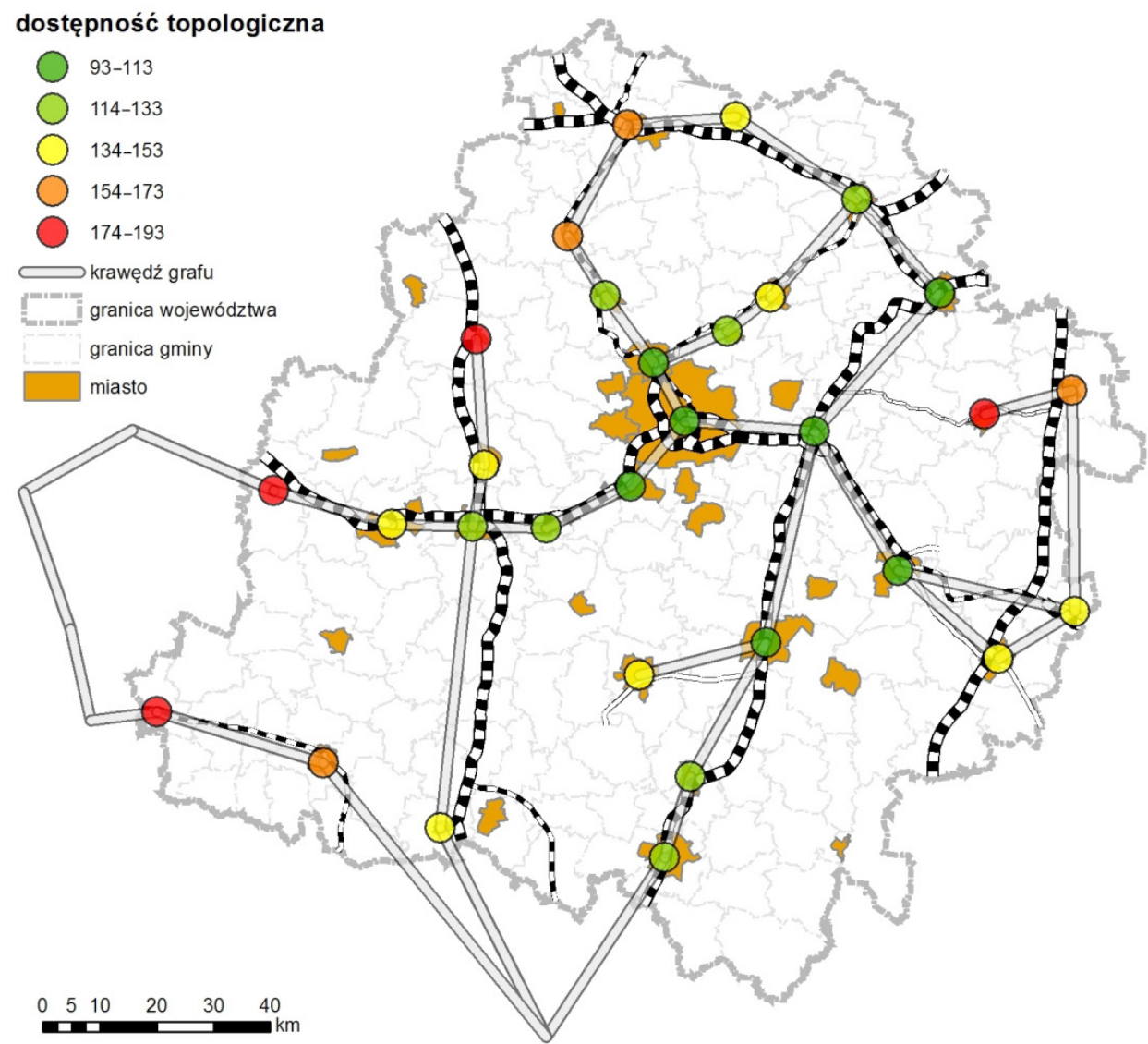

Rycina 2.23. Przestrzenne zróżnicowanie dostępności topologicznej miast województwa łódzkiego w sieci kolejowej

Źródło: opracowanie własne

Niemniej jednak węzły o najwyższym poziomie dostępności topologicznej również są zlokalizowane w centrum województwa. Są to: Tomaszów Mazowiecki (113), Zgierz (112), Skierniewice (111), Piotrków Trybunalski (109), Pabianice (105), Łódź (97) oraz Koluszki (93) będące węzłem o najwyższym poziomie dostępności w sieci kolejowej. Najniższym poziomem dostępności topologicznej odznacza się Wieruszów (192). Podobnie wysokie wartości charakteryzują tak- 
że Rawę Mazowiecką (190), Poddębice (180) oraz Błaszki (178). Dyspersja grafu przedstawiającego sieć kolejową województwa łódzkiego wynosi 4154, a przeciętna długość drogi to 4,6.

Analizując dostępność topologiczną miast województwa łódzkiego objętych siecią tramwajową, należy wskazać Łódź, jako węzeł najbardziej dostępny. Drugim w kolejności węzłem jest Zgierz, dla którego liczba asocjacji względem pozostałych czertach miast wynosi 6. Konstantynów Łódzki i Pabianice charakteryzują się dostępnością na tym samym poziomie, będąc jednocześnie bardziej dostępnymi od Ozorkowa. Dyspersja grafu przedstawiającego sieć tramwajową województwa łódzkiego wynosi 36, a przeciętna długość drogi to 1,4. Przeprowadzone analizy wskazały jednoznacznie miasta będące punktami centralnymi dla poszczególnych rodzajów sieci. Nie wystąpiła zatem konieczność ich wyodrębniania z większej grupy, poprzez wprowadzenie wskaźnika względnej dostępności topologicznej.

Kolejną metodą oceny dostępności miast województwa łódzkiego jest wprowadzenie wskaźnika $S-I$, opracowanego przez Orda (1967), opierającego się na trzech pierwszych momentach centralnych ${ }^{33}$. Dla grafu o określonej liczbie wierzchołków należy najpierw opracować macierz zero-jedynkowych połączeń (1 istnienie bezpośredniego połączenia pomiędzy parą miast; 0 - brak połączenia). W dalszej kolejności konieczne jest wyznaczenie macierzy oddaleń ${ }^{34}$. Po skonstruowaniu macierzy ${ }^{35}$ odpowiadającej rozważanemu grafowi należy skonstruować rozkład liczebności $\left(f_{1}\right)$ oddaleń (1). Oznaczając $N$ jako sumę liczebności oddaleń, możliwe jest określenie rozkładu częstości. Kolejny etap analizy obejmuje obliczenie trzech pierwszych momentów centralnych rozkładu częstości oddaleń badanych grafów. Największa wartość w macierzy oddaleń to średnica grafu $(\delta)$. Warto zauważyć, że taką samą wartość średnicy mogą mieć sieci znacznie różniące się bezwzględnymi rozmiarami. Obliczane są tutaj oddalenia w sensie topologicznym, a nie odległości w sensie fizycznym:

- pierwszy moment centralny $\mu_{1}=\frac{1}{N} \sum_{\mathrm{l}=0}^{\delta} f_{l} \cdot l$;

${ }^{33}$ Momenty są średnimi arytmetycznymi z odchyleń wartości zmiennej $x_{i}$ od dowolnej liczby $x_{0}$ podniesionej do $r$-tej potęgi. Momenty pozwalają wyznaczyć średni poziom badanej cechy zmiennej, poziom zróżnicowania poszczególnych jednostek zbiorowości w stosunku do średniej arytmetycznej $x$, stopień asymetrii czy też stopień koncentracji. W zależności od tego, czy wielkością dowolną $x_{0}$ jest zero, czy też średnia arytmetyczna $x$, możliwe jest obliczenie odpowiednio momentów zwykłych lub centralnych. Moment centralny I stopnia jest równy średniej arytmetycznej, moment II stopnia jest wariancją, III stopnia miarą asymetrii, a moment centralny IV stopnia jest miarą skupienia danych.

${ }^{34}$ Oddaleniem $d_{x y}$ wierzchołka $x$ do $y$ nazywamy długość najkrótszej drogi od $x$ do $y$.

${ }^{35}$ Macierz oddaleń można otrzymać, zastępując w macierzy zero-jedynkowej zera - z wyjątkiem leżących na głównej przekątnej - liczbą krawędzi liczonych wzdłuż najkrótszej drogi między każdą parą węzłów. 
- drugi moment centralny: $\mu_{2}=\frac{1}{N} \sum_{1=0}^{\delta} f_{l} \cdot(l-\bar{l})^{2}$;

- trzeci moment centralny: $\mu_{2}=\frac{1}{N} \sum_{l=0}^{\delta} f_{l} \cdot(l-\bar{l})^{3}$.

Współrzędne $S$ oraz $I$ wskaźnika $S-I$ określono następująco: $S=\frac{\mu_{3}}{\mu_{2}} ; I=\frac{\mu_{2}}{\mu_{1}}$. Jeśli wartości $S$-I zostaną obliczone dla każdego węzla (zgodnie z algorytmem postępowania przedstawionym wcześniej), wówczas możliwe jest ich różnicowanie w obrębie grafu. Wykorzystując tę możliwość, określono dostępność węzłów sieci transportowych zgodnie ze wskaźnikiem S-I. Jego wartość określają dwie zmienne $S$ oraz $I$, dlatego też przyjęto interpretację, w której wartości wskaźnika naniesiono na wykres, a z niego odczytano wypadkową $S$ oraz $I$, czyli wielkość promienia $r$ od punktu zerowego współzzędnych wykresu. Wielkość wskaźnika S-I zależy od analizy rozkładu częstości oddaleń badanego grafu. Zatem bardziej dostępny jest ten węzeł, dla którego przeważają znikome wielkości oddaleń od wszystkich pozostałych węzłów i w wyniku tego mała wartość $r$. I odwrotnie, węzeł mniej dostępny to ten, dla którego charakterystyczne są większe wielkości oddaleń i duża wartość $r$.

Przestrzenny rozkład dostępności węzłów według wskaźnika S-I (rycina 2.24) dla sieci drogowej województwa łódzkiego przypomina obraz dostępności topologicznej. Podobnie jak w przypadku tej ostatniej charakterystyczne jest skupienie węzłów najlepiej dostępnych w centralnej części sieci. Wraz z oddalaniem się od centrum dostępność węzłów maleje mniej więcej równomiernie we wszystkich kierunkach, chociaż ogólnie występuje mniejsza regularność w rozkładzie przestrzennym niż w przypadku dostępności topologicznej (Taylor 1979). Wartość $r$ dla poszczególnych węzłów wskazuje, że najwyższym poziomem dostępności charakteryzuje się Konstantynów Łódzki $(0,55)$, którego dostępność topologiczna plasowana jest dopiero na ósmym miejscu. Niskie wartości $r$ dotyczą również Koluszek $(0,64)$, Strykowa $(0,66)$, Tuszyna $(0,66)$, Piotrkowa Trybunalskiego $(0,67)$, Radomska $(0,75)$, Skierniewic $(0,76)$ oraz Sulejowa $(0,82)$. Największym oddaleniem od punkt zerowego wspótrzędnych wykresu odznacza się Biała Rawska $(1,94)$. Podobnie niski poziom dostępności charakteryzuje Wolbórz $(1,86)$, Wieruszów $(1,81)$ oraz Błaszki $(1,75)$.

Rozkład przestrzenny dostępności węzłów w sieci kolejowej zgodnie ze wskaźnikami $S-I$ charakteryzuje się wyraźnym skupieniem węzłów najlepiej dostępnych w centrum województwa, podobnie jak w przypadku sieci drogowej, natomiast jest to prawidłowość znacznie bardziej wyraźna (rycina 2.25). Najlepiej dostępnym węzłem w świetle wskaźnika S-I jest Łask, którego oddalenie od początku układu współrzędnych wynosi 0,819 . Zgodnie z dostępnością topologiczną, Łask jest jednak węzłem wyraźnie mniej dostępnym (o siedem miejsc). Wysoką dostępnością w świetle wskaźnika S-I charakteryzuje się również Łódź $(0,822)$ oraz Piotrków Trybunalski $(0,905)$. Największe wartości $r$ dotyczą Rawy Mazo- 


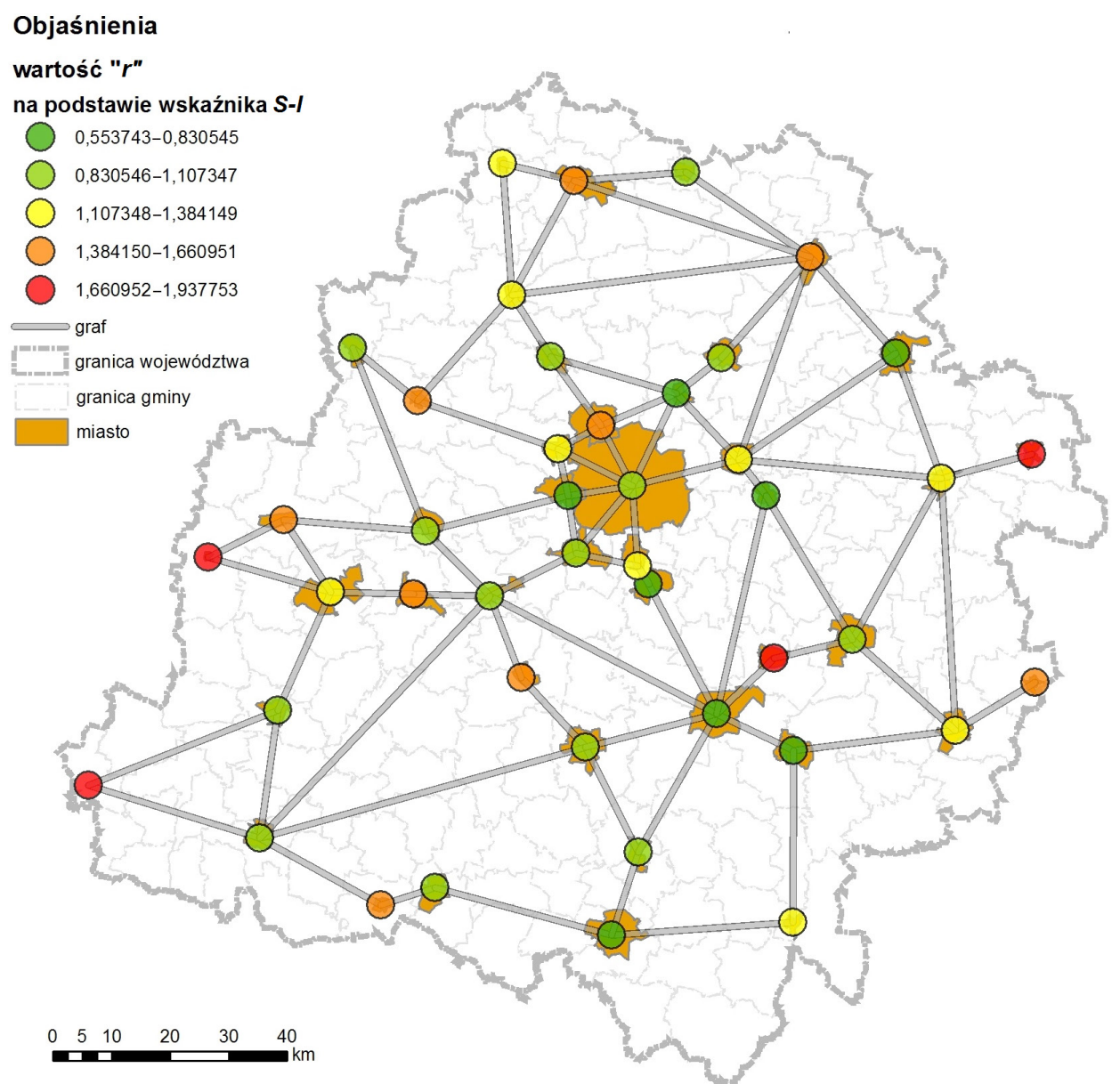

Rycina 2.24. Przestrzenne zróżnicowanie wartości $r$ na podstawie wskaźnika $S$-I miast województwa łódzkiego w sieci drogowej

Źródło: opracowanie własne

wieckiej $(2,484)$ oraz Wieruszowa $(2,767)$, który jest węzłem o najniższym poziomie dostępności.

Dostępność węzłów w grafie obrazującym sieć tramwajową województwa łódzkiego pokrywa się z wynikami analizy wcześniej określonej dostępności topologicznej. Łódź jest węzłem o najwyższym poziomie dostępności $(0,4)$. Oddalenie od początku układu współrzędnych dla Zgierza $(0,6)$ oraz jednakowe dla Pabianic i Konstantynowa Łódzkiego $(0,65)$ plasuje je odpowiednio na drugim i ex aequo trzecim miejscu pod względem dostępności. Najniższy jej poziom dotyczy Ozorkowa $(0,9)$. 


\section{Objaśnienia}

\section{wartość "r"}

na podstawie wskaźnika S-I

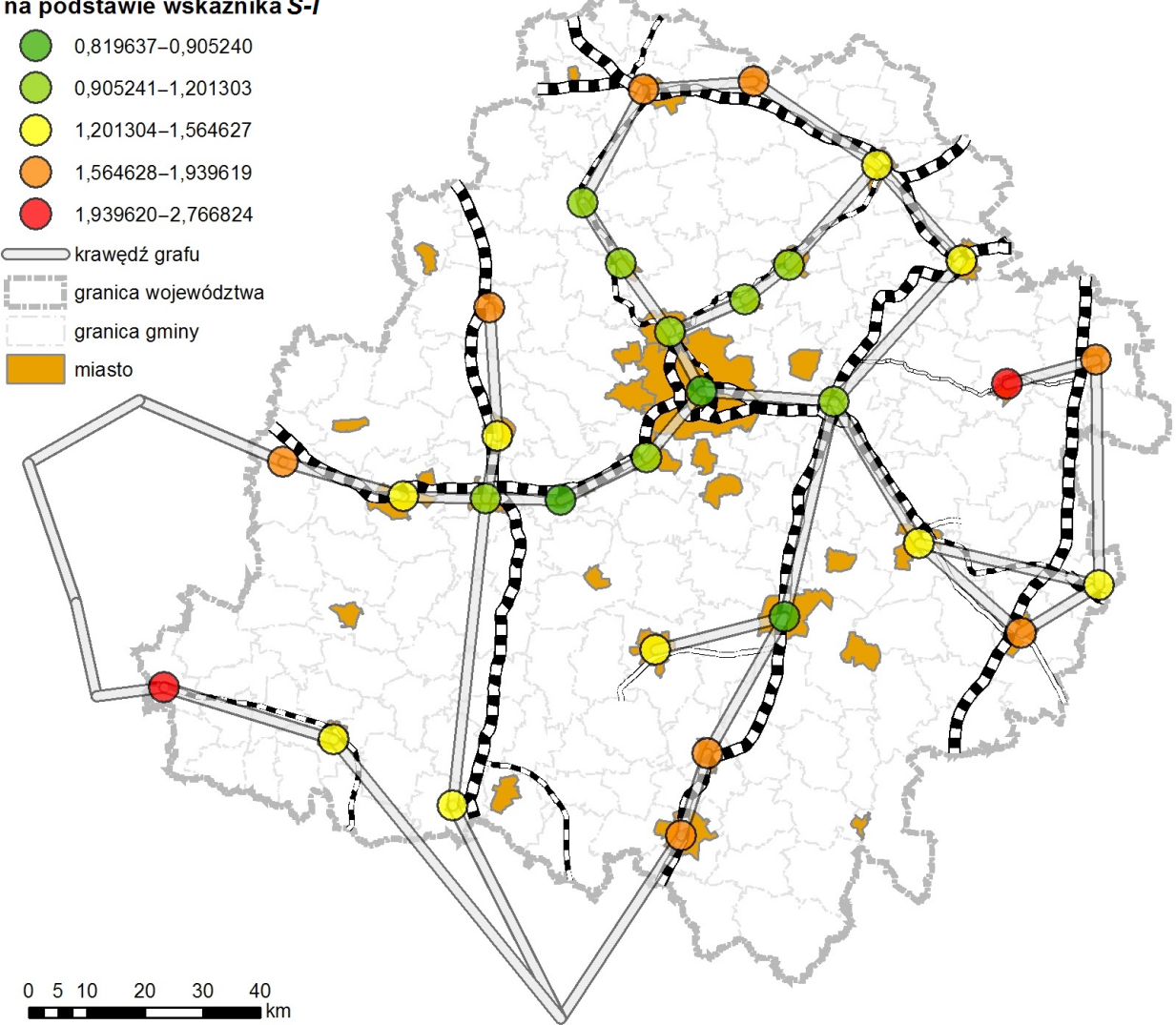

Rycina 2.25. Przestrzenne zróżnicowanie wartości $r$ na podstawie wskaźnika $S$ - I miast województwa łódzkiego w sieci kolejowej

Źródło: opracowanie własne

Celem uwzględnienia oddziaływań z miastami na zewnątrz województwa łódzkiego skonstruowano grafy obrazujące jego sieć drogową i kolejową funkcjonującą w ujęciu międzyregionalnym. Przyjęto założenie włączenia węzłów obrazujących stolice województw graniczących z województwem łódzkim (Warszawa, Kielce, Kraków, Katowice, Opole, Wrocław, Poznań, Bydgoszcz). Pozostałe węzły leżące poza granicą województwa łódzkiego włączono do badania, jeżeli zlokalizowane były w granicy ekwidystanty $150 \mathrm{~km}$ od centroida województwa łódzkiego. W przypadku grafu obrazującego sieć drogową krawędzie poprowadzono zgodnie z przebiegiem dróg krajowych. 
Poddając analizie zróżnicowanie przestrzenne dostępności topologicznej miast województwa łódzkiego w sieci drogowej w ujęciu międzyregionalnym (rycina 2.26), należy podkreślić wysoki poziom dostępności miast - węzłów położo-

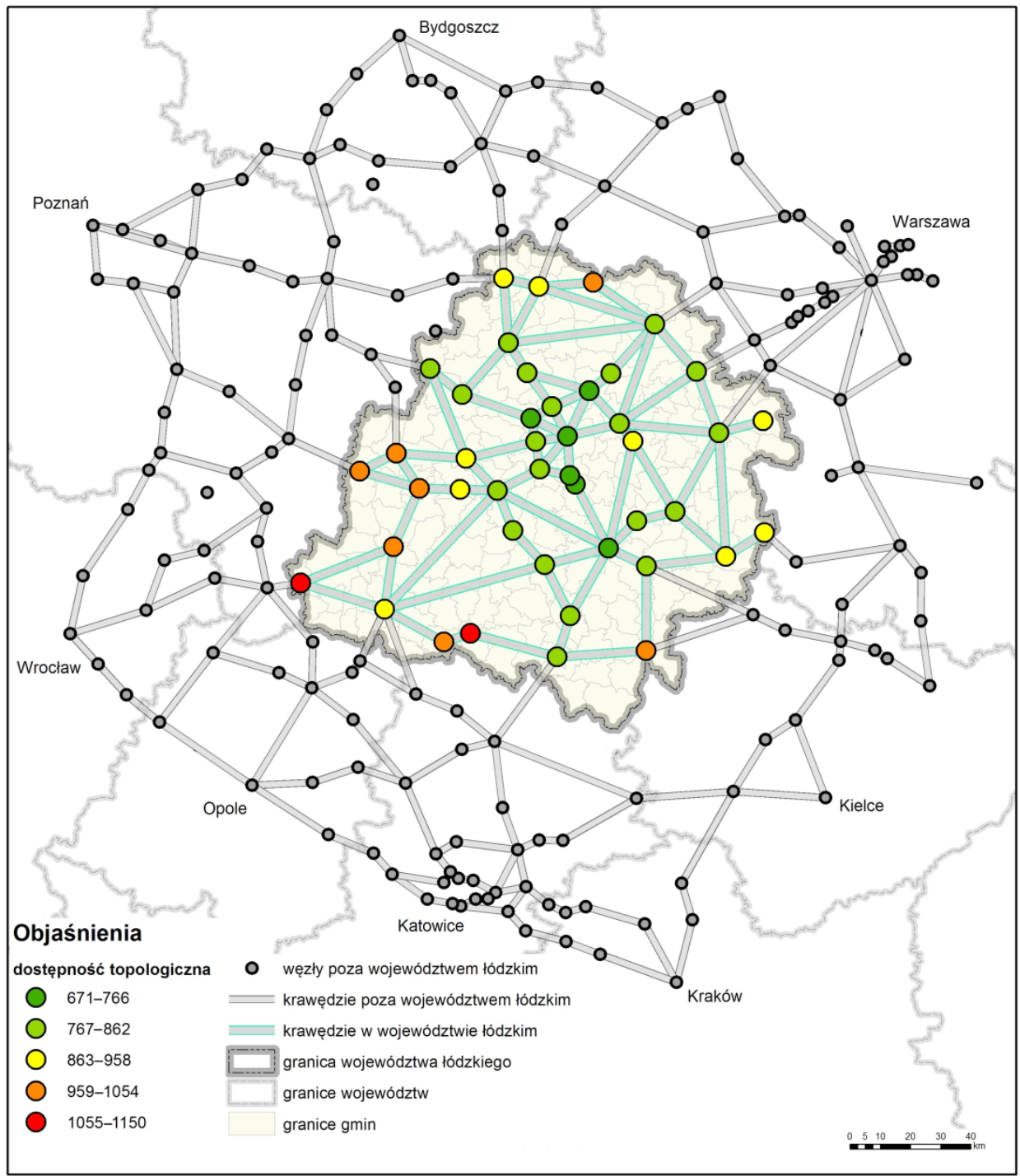

Rycina 2.26. Przestrzenne zróżnicowanie dostępności topologicznej miast województwa łódzkiego w sieci drogowej w ujęciu międzyregionalnym 
nych w przebiegu autostrady A2 oraz na osi północ-południe przechodzącej przez centrum województwa.

W stosunku do poziomów dostępności węzłów przy ograniczeniu analizy do granicy województwa uwidacznia się ich wzrost wraz z przemieszczaniem się ku

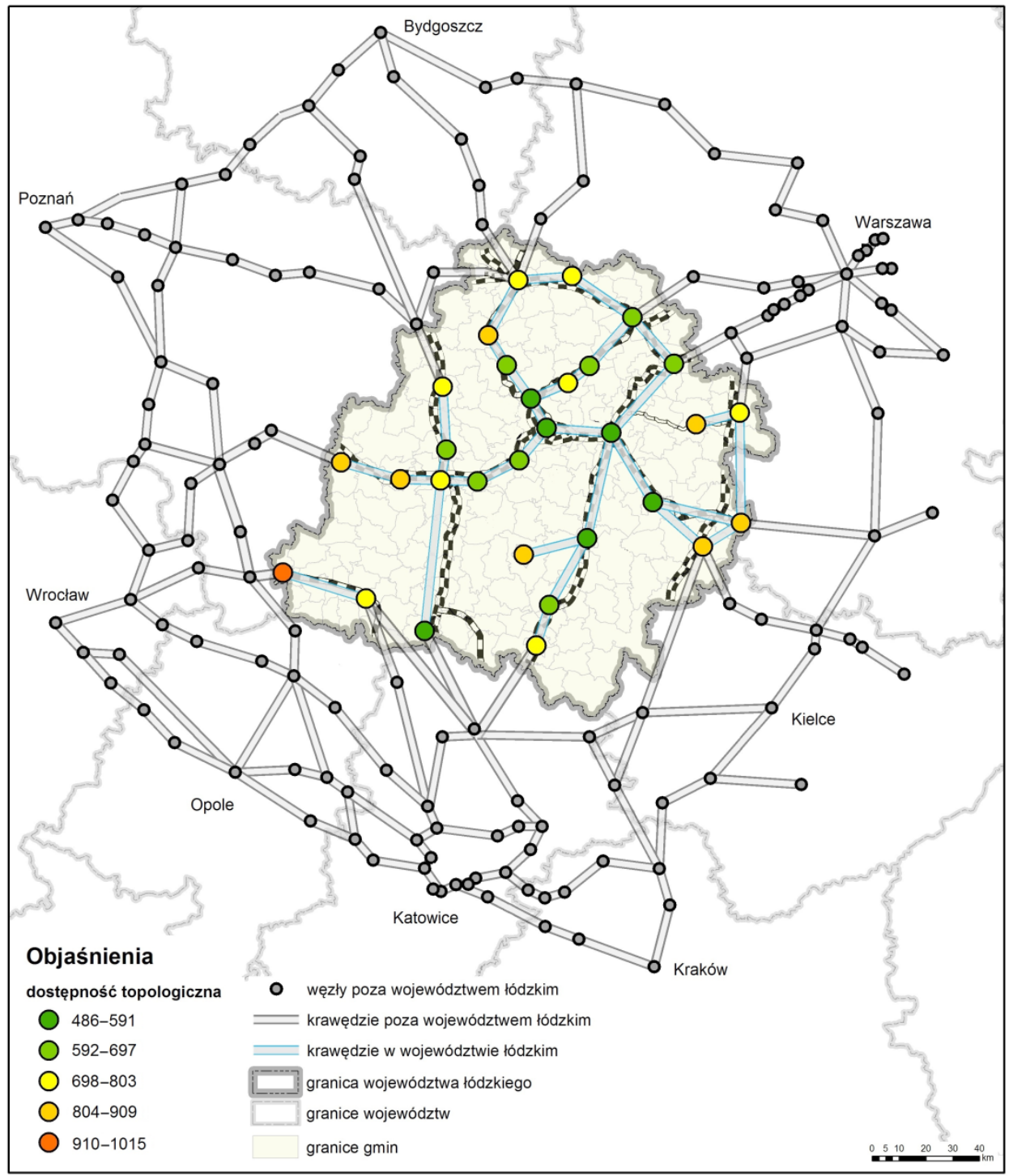

Rycina 2.27. Przestrzenne zróżnicowanie dostępności topologicznej miast województwa łódzkiego w sieci kolejowej w ujęciu międzyregionalnym 
wschodniej granicy regionu. Powyższe prawidłowości tłumaczyć można ponadregionalnym charakterem autostrady, który nie miał szans ujawnić się przy domknięciu analizy do granic województwa oraz „ciążenia” dużej liczby węzłów zlokalizowanych w granicach województwa mazowieckiego i śląskiego.

W przypadku sieci kolejowej przestrzenne zróżnicowanie dostępności topologicznej miast województwa łódzkiego w ujęciu międzyregionalnym (rycina 2.27) nie uległo tak wyraźnym zmianom w stosunku do stanu przy ograniczeniu do granic województwa jak w odniesieniu do sieci drogowej. Widoczny jest ogólny wzrost poziomu dostępności poszczególnych węzłów. Wyraźne wzrosty towarzyszą szczególnie miastom - węzłom zlokalizowanym w przebiegu magistrali węglowej oraz Centralnej Magistrali Kolejowej, czego przyczyny tożsame są dla przedstawionej wcześniej sytuacji autostrady A2. Niezmiennie jednak najgorzej dostępnym węzłem w ujęciu sieci kolejowej pozostaje Wieruszów.

\subsection{Dostępność a wyposażenie infrastrukturalne}

Centralne położenie województwa łódzkiego w kraju, dodatkowo wsparte o dostęp do dwóch z czterech funkcjonujących na obszarze Polski paneuropejskich korytarzy transportowych oraz planowane utworzenie Centralnego Węzła Komunikacyjnego stwarzają ogromne szanse rozwojowe dla infrastruktury transportowej (Strategia rozwoju województwa łódzkiego 2020). Jak już wspomniano, województwo łódzkie jest stosunkowo dobrze wyposażone w drogi publiczne o nawierzchni twardej. Sieć dróg krajowych należy do jednych $\mathrm{z}$ najdłuższych w kraju. Region jest też dobrze wyposażony w sieć dróg powiatowych i gminnych, jednakże parametry tych dróg w większości są nieprzystosowane do przenoszonych obciążeń i natężenia ruchu. Stan techniczny funkcjonującego układu drogowego systematycznie się poprawia, jednak drogi nadal wykazują duże potrzeby remontowe. Od 2004 r. etapowo zmodernizowano przeszło $750 \mathrm{~km}$ dróg wojewódzkich. W 2012 r. zakończono budowę obwodnicy Strykowa w ciągu drogi wojewódzkiej nr 708. Od 2004 r. zrealizowano także autostradę A2, odcinek autostrady A1 Stryków-Kowal, drogę ekspresową S8 Piotrków Trybunalski-Warszawa, część drogi ekspresowej S14 i pięć obejść miast (Rawy Mazowieckiej, Kutna, Krośniewic, Opoczna oraz Pabianic) w ciągu dróg krajowych, co umożliwiło wyeliminowanie ciężkiego ruchu tranzytowego. W realizacji znajduje się droga ekspresowa S8 relacji Łódź-SieradzWrocław oraz odcinek autostrady A1 Stryków-Tuszyn. Realizacja kluczowego układu drogowego tworzonego przez autostrady i drogi ekspresowe umożliwi pełne wykorzystanie strategicznego położenia województwa w kraju i Europie. 
Poza inwestycjami o charakterze strategicznym konieczna jest również realizacja efektywnego systemu dróg dojazdowych do węzłów autostradowych i węzłów na drogach ekspresowych. Województwo odznacza się stosunkowo słabo rozwiniętą siecią kolejową: niską gęstością sieci kolejowej oraz niskimi parametrami technicznymi większości linii. Problem stanowi brak przebiegu przez Łódź magistrali kolejowych o znaczeniu międzynarodowym w sieci TEN-T oraz brak dobrych połączeń z głównymi miastami w kraju. Sieć kolejowa województwa potrzebuje inwestycji skierowanych na przywrócenie normalnych prędkości rozkładowych oraz eliminację ograniczeń prędkości na funkcjonujących liniach. Możliwości eliminacji problemów z obsługą kolejową województwa można upatrywać w budowie (w ramach projektu TEN-T) Kolei Dużych Prędkości pomiędzy Warszawą, Łodzią a Wrocławiem i Poznaniem. Realizacji inwestycji towarzyszyć ma budowa tunelowego przejścia pod centrum Łodzi połączona z trwającą aktualnie budową podziemnej stacji Łódź Fabryczna.

Plany obejmują również modernizację lub budowę linii konwencjonalnych o wysokich parametrach (m.in. tunel średnicowy Łódź Fabryczna-Lódź Kaliska), uwzględniając jednocześnie włączenie do sieci połączeń Łódzkiej Kolei Aglomeracyjneje (ibid.).

Realizacja założonych inwestycji przyczyni się zapewne do istotnej poprawy dostępności transportowej i przestanie stanowić problem o charakterze opóźnienia cywilizacyjnego i bariery rozwojowej. W ramach infrastruktury kolejowej poza modernizacją głównych linii konieczna jest również wymiana taboru. Szczególne znaczenie dla kolejowej obsługi regionu będzie mieć centralny węzeł multimodalny Łódź Fabryczna, spięty wspomnianym tunelem średnicowym dla kolei konwencjonalnej. Łódzka Kolej Aglomeracyjna, w powiązaniu z Łódzkim Tramwajem Regionalnym oraz tramwajem „Wschód-Zachód”, zapewniać będzie wysoką efektywność całego systemu transportu publicznego w regionie. Do 2020 r. zostanie podjęta decyzja o budowie i harmonogramie prac dotyczących budowy Kolei Dużych Prędkości (ibid.).

Powyższa diagnoza i kierunki rozwoju dotyczą jednak skali regionalnej lub jedynie samej Łodzi. W celu zdiagnozowania i ustalenia ewentualnych wytycznych mających ją poprawić na poziomie lokalnym konieczne jest ujęcie szczegółowe odnoszące się do każdego z miast województwa osobno, a nie traktowanie ich tylko jako spójnej całości. Analizy wyposażenia infrastrukturalnego są szczególnie istotne, bowiem na ich podstawie możliwe jest m.in. planowanie rozbudowy, infrastruktury, co może znacząco wpływać na szereg aspektów funk-

${ }^{36}$ Należy wspomnieć, że przebieg linii kolejowych nie nawiązuje do współczesnej sieci osadniczej regionu. Przystanki są $\mathrm{w}$ wielu przypadkach zlokalizowane $\mathrm{z}$ dala od centrów miejscowości (np. w Łodzi planowane obiekty ŁKA nie pokrywają się z rozmieszczeniem większych osiedli mieszkaniowych). Dlatego też przydatność ŁKA dla potencjalnych użytkowników jest uzależniona od jej powiązania z pozostałymi środkami transportu zbiorowego, drogami rowerowymi czy parkingami typu park \& ride (Bartosiewicz, Pielesiak 2012). 
cjonowania miast. Po pierwsze, inwestycje w infrastrukturę transportową warunkują zmiany w dostępności poszczególnych regionów lub punktów (efekt rozwoju sieci transportowej lub podwyższenia jej standardu). Wpływają również na produktywność, koszty i skalę produkcji oraz lokalizację działalności gospodarczej i skłonność do podejmowania inwestycji w sektorze prywatnym. Wpływ rozbudowy infrastruktury widoczny jest także $\mathrm{w}$ zakresie handlu i wymiany międzyi wewnątrzregionalej (Domańska 2006).

Dlatego też szczegółowej analizie poddano wyposażenie infrastrukturalne dla każdego z miast województwa łódzkiego. Badanie zostało wykonane w buforach, których granice były ekwidystantami o kształcie granicy każdego z miast, oddalonymi od rzeczywistych granic o 5, 10 i $15 \mathrm{~km}$ (Lijewski 2000). Tworzyły im pierścienie o układzie $0-5,5-10$ oraz $10-15 \mathrm{~km}$. Występowanie elementów infrastruktury transportowej w otoczeniu miast (w odległości do $15 \mathrm{~km}$ od jego granic) daje zwiększoną potencjalną możliwość dotarcia do nich, podnosząc tym samym poziom dostępności w skali lokalnej. Jeśli zostaną poddane analizie również węzły autostradowe i na drogach ekspresowych oraz stacje kolejowe, badanie nabierze znacznie szerszego wymiaru. Z drugiej zaś strony, drogi o ograniczonej dostępności i linie kolejowe mogą stanowić silną barierę w realizacji przemieszczeń w skali lokalnej.

Do analizy nie zostało włączone wyposażenie infrastrukturalne badanego miasta, natomiast zliczano je, jeśli było objęte buforem innego miasta poddanego analizie. Badania mają zarówno aspekt ilościowy, jak i jakościowy. Skupiając się na danych ilościowych, zliczono długości wszystkich dróg powiatowych, wojewódzkich oraz krajowych (w tym dróg ekspresowych i autostrad) oraz normalno- i wąskotorowych linii kolejowych, znajdujących się w poszczególnych buforach 44 miast województwa łódzkiego. W przypadku dróg dwujezdniowych i linii dwutorowych nie podwajano zmierzonej długości. Ich wyższe parametry znalazły swoje odzwierciedlenie w ujęciu jakościowym, które zostanie wprowadzone w dalszej części rozdziału. Dodatkowo określono liczbę skrzyżowań dróg krajowych i wojewódzkich, dającą pewną informację na temat przestrzennego układu sieci. W przypadku dróg z ograniczoną dostępnością zliczano węzły, a więc miejsca zjazdów i wjazdów na daną drogę - jedyne punkty umożliwiające włączenie się do ruchu (z wyjątkiem sytuacji wyjątkowych). Punktowe elementy infrastruktury (stacje, przystanki) zliczano również w przypadku sieci kolejowej i tramwajowej. Jedynie $\mathrm{w}$ tych punktach istnieje możliwość skorzystania $\mathrm{z}$ transportu pociągiem czy tramwajem. Ze względu na dużą ilość prowadzonych inwestycji infrastrukturalnych do analizy włączono, poza aktualnym stanem infrastruktury województwa, także elementy sieci drogowej będące w realizacji zgodnie z informacjami przekazanymi przez Generalną Dyrekcję Dróg Krajowych i Autostrad. Dotyczy to drogi ekspresowej S8 na odcinkach Wieruszów-Walichnowy, Walichnowy-Węzeł Złoczew, Złoczew-Węzeł „Sieradz Południe”, „Sieradz Południe”Łask, Węzeł Łask-Węzeł Róża, Róża-A1 Węzeł „Łódź Południe” wraz z łączni- 
kiem drogi krajowej nr 12 do drogi ekspresowej S8, a ponadto odcinek drogi S14: Węzeł Dobroń-Łódź (zachodnia obwodnica Pabianic S14 + dk 14 bis) oraz dwa odcinki autostrady A1: Węzeł „Łódź Północ-Węzeł Tuszyn i Węzeł StrykówWęzeł „Łódź Południe”. Dane na temat realizowanych inwestycji, zwłaszcza tych o najwyższej randze, mają za zadanie przedstawić przyszły stan zainwestowania infrastrukturalnego, natomiast rozwój transportu drogowego jest w Polsce dość powszechnie uważany za najbardziej oczywisty kierunek poprawy infrastruktury wspomagającej przedsiębiorczość i integrację gospodarki polskiej z europejską (Bartczak, Żylicz 2005). Ze względu jednak na charakter niniejszej pracy skupiającej się na sytuacji aktualnej, zmiany wynikające z realizacji inwestycji nie będą uwzględniane w dalszych analizach, służą bowiem jedynie prezentacji. W przypadku sieci kolejowej oraz tramwajowej, w momencie tworzenia niniejszej pracy nie były realizowane żadne nowe inwestycje. Wykonywano jedynie prace modernizacyjne i konserwacyjne.

Analiza podaży wyposażenia infrastrukturalnego obszarów wokół miast w ujęciu bezwzględnych długości obiektów liniowych i liczby obiektów punktowych powinna jednak być połączona z analizą popytu na transport, chociażby w ujęciu potencjalnym. Konieczne jest również wprowadzenie do analizy ilościowej elementów różnicujących wyposażenie infrastrukturalne pod względem jakościowym. Aby zawrzeć obydwa wskazane powyżej elementy, zdecydowano się na wprowadzenie do analizy wskaźnika średnioważonego dla wyposażenia infrastrukturalnego. Został on zastosowany przez Komornickiego i in. (2008) do określenia dostępności do sieci transportowych na potrzeby opracowania metodologii liczenia wskaźnika międzygałęziowej dostępności transportowej terytorium Polski. W oryginalnym badaniu jednostkami badawczymi były województwa, natomiast na potrzeby niniejszej pracy zaadaptowano metodę do analizy na poziomie buforów wokół miast. Uwzględniono zarówno ilość (tj. długość dróg oraz linii kolejowych i tramwajowych), jak i jakość infrastruktury, czyli długość wybranych kategorii dróg i linii ważoną maksymalną dopuszczalną prędkością poruszania się po nich. We wskaźniku średnioważonym wzięto pod uwagę liczbę mieszkańców miasta i powierzchnię badanego buforu. Analizy dokonano w podziale na wyposażenie w elementy sieci drogowej, kolejowej oraz kolejowo-tramwajowej, a ponadto w rozróżnieniu na trzy wspomniane wcześniej bufory. Wskaźnik średnioważony dla wyposażenia infrastrukturalnego $(W S ́ W I)$ ma postać:

$$
W S W I=w_{i l o} \frac{\frac{W I_{i l o}}{\sqrt{P O P_{m} \cdot P O W_{b}}}}{\frac{\sum W I_{i l o}}{\sqrt{\sum P O P_{m} \cdot \sum P O W_{b}}}}+w_{j a k} \frac{\frac{W I_{j a k}}{\sqrt{P O P_{m} \cdot P O W_{b}}}}{\frac{\sum W I_{j a k}}{\sqrt{\sum P O P_{m} \cdot \sum P O W_{b}}}},
$$

gdzie:

$W I_{i l o}$ - długość dróg lub linii kolejowych i tramwajowych w buforze, 
$W I_{j a k}$ - ważona długość dróg lub linii kolejowych i tramwajowych w buforze, $P O P_{m}$ - liczba ludności miasta, $P O W_{b}$ - powierzchnia buforu, $W_{i l o}, W_{j a k}-0,5^{37}$.

W mianownikach wzoru sumowane są odpowiednio ilości infrastruktury oraz ważone ilości infrastruktury dla całej zbiorowości 44 miast oraz powierzchnie buforów i liczba ludności całej zbiorowości miast. Wskaźnik obliczany jest dla każdego z buforów osobno i dopiero w dalszej analizie poddawany odpowiednim sumowaniom. W badaniu elementów sieci drogowej, jak i kolejowej oraz tramwajowej uwzględniono wszystkie miasta województwa łódzkiego, ponieważ jeśli nawet dane miasto nie posiada stacji czy przystanku kolejowego/tramwajowego, to w jego najbliższym otoczeniu taki element infrastruktury może się znaleźć i potencjalnie zwiększać poziom dostępności. Przy ustalaniu wag dla infrastruktury wykorzystano informacje na temat maksymalnych prędkości, z jakimi dozwolone jest poruszanie się po nich. W przypadku sieci drogowej prędkości te zaczerpnięto z Prawa o ruchu drogowym ${ }^{38}$ dla samochodu osobowego, przy przyjęciu wartości poza obszarem zabudowanym. Wagi ustalano w taki sposób, że jeśli maksymalna prędkość podróży samochodu osobowego po autostradzie równa się $140 \mathrm{~km} / \mathrm{h}$, to waga, przez którą mnożono długość danego odcinka w metrach, wynosi 1,4. Dla drogi ekspresowej dwujezdniowej, prędkość maksymalna jest równa $120 \mathrm{~km} / \mathrm{h}$, a więc waga wynosi 1,2. Dla drogi ekspresowej jednojezdniowej oraz drogi dwujezdniowej, co najmniej o dwóch pasach przeznaczonych dla każdego kierunku ruchu (krajowe i wojewódzkie), waga wynosi 1. Jednojezdniowe drogi krajowe i wojewódzkie były ważone wartością 0,9 . Jedynie dla dróg powiatowych wartość przypisano arbitralnie w wysokości 0,6 , aby odróżnić je wyraźnie od dróg krajowych i wojewódzkich. W przypadku dróg o ograniczonej dostępności do obliczenia wskaźnika średnioważonego włączano jedynie te odcinki, na długości których znajdował się węzeł. W części analizy poświęconej sieci kolejowej wagi poszczególnych odcinków ustalono na podstawie wykazu maksymalnych prędkości dla pociągów pasażerskich, stanowiącego załącznik 2.1 do regulaminu przydzielania tras pociągów i korzystania z przydzielonych tras pociągów przez licencjonowanych przewoźników kolejowych w ramach rj 2012/2013 (w. 0), udostępnionego przez PKP Polskie Linie Kolejowe S.A.

Kilometraż dla punktów początkowych i końcowych poszczególnych odcinków z daną prędkością przyjęto dla toru nieparzystego. Wagi dla sieci kolejowej ustalono na tej samej zasadzie jak dla sieci drogowej. Jeśli na danym odcinku obowiązuje maksymalna prędkość $160 \mathrm{~km} / \mathrm{h}$, to waga wynosi 1,6 . Nie wprowadzono dodatkowego różnicowania ze względu na elektryfikację, ponieważ jedy-

${ }^{37}$ Przyjęto zgodnie z Komornickim i in. (2008).

${ }^{38}$ Ustawa z dania 20 czerwca 1997 r. Prawo o ruchu drogowym, Dz.U. 1997, nr 98, poz. 602 wraz z późn. zm. 
nie linia Tomaszów Mazowiecki- Skarżysko Kamienna nie jest zelektryfikowana. Niemożliwe stało się również włączenie do analizy jakościowej linii wąskotorowej Rogów-Rawa Mazowiecka-Biała Rawska, ze względu na brak informacji dotyczących prędkości poruszania się pociągów. Możliwe byłoby ustalenie prędkości eksploatacyjnych, ale wyłącznie pomiędzy przystankami Rogów Osobowy Wąskotorowy a Jeżów, gdzie okresowo odbywa się regularny ruch pociągów.

Podobnie jak w przypadku dróg o ograniczonej dostępności, również w przypadku linii kolejowych do analizy włączono tylko odcinki, na długości których znajdował się przystanek lub stacja, tzn. potencjalnie dostępnych dla pasażerów. W przypadku analizy linii tramwajowych, jako źródło do ustalenia przebiegu linii wykorzystano dane udostępnione przez Zarząd Dróg i Transportu w Łodzi. Ponieważ nie zostały udostępnione informacje dotyczące maksymalnych dopuszczalnych prędkości tramwajów na poszczególnych odcinkach sieci, obliczono prędkości eksploatacyjne na poszczególnych liniach. Przykładowo, jeśli na odcinku tramwaj porusza się ze średnią prędkością eksploatacyjną $23 \mathrm{~km} / \mathrm{h}$, to długość odcinka zostanie zważona wartością 0,23 . Oczywiście prędkość eksploatacyjna nie musi odpowiadać jakości linii, bowiem m.in. linia umożliwiająca podróż z wysoką prędkością może posiadać dużą liczbę przystanków, które wyraźnie ją obniżają. Do analizy włączono wyłącznie odcinki linii tramwajowych, które w danym buforze wyposażone są w przystanki.

Wskaźnik średnioważony wyposażenia infrastrukturalnego dla sieci drogowej wokół miast województwa łódzkiego charakteryzuje się małym zróżnicowaniem (współczynnik zmienności wynosi 5,8\%), wskaźniki dla poszczególnych miast odchylają się od średniej zaledwie o 0,18 (tabela 2.3). Również zróżnicowanie wyposażenia pomiędzy poszczególnymi buforami dla całej zbiorowości miast jest małe, gdyż średnio odchyla się o 0,11 . Najmniejsze różnice w wyposażeniu dotyczą Sieradza (suma wartości bezwzględnych z różnic pomiędzy buforem 5- i 10-kilometrowym oraz 10- i 15-kilometrowym wynosi 0,03). Największe zróżnicowanie pomiędzy buforami dotyczy Uniejowa $(0,62)$. Jest to miasto najgorzej wyposażone w elementy sieci drogowej w stosunku do powierzchni i liczby potencjalnych użytkowników. Najwyższym wskaźnikiem średnioważonym charakteryzuje się Konstantynów Łódzki. O jego wysokiej pozycji zadecydowała przede wszystkim gęsta sieć dróg powiatowych, wynikająca z sąsiedztwa Łodzi.

Zróżnicowanie wskaźnika średnioważonego wyposażenia infrastrukturalnego dla sieci kolejowej jest znacznie większe niż dla sieci drogowej (współczynnik zmienności wynosi 48\%), wskaźniki dla poszczególnych miast odchylają się od średniej o 1,16. Wynika to z przestrzennego układu sieci kolejowej, której rozmieszczenie jest zdecydowanie mniej regularne niż sieci drogowej. W przypadku Złoczewa, Sulejowa, Przedborza, Rawy Mazowieckiej oraz Białej Rawskiej w żadnym z trzech buforów nie znalazły się odcinki linii kolejowych, na których zlokalizowano przystanek czy stację (rycina 2.28). Zróżnicowanie wyposażenia pomiędzy poszczególnymi buforami dla całej zbiorowości miast również jest 
Tabela 2.3. Wskaźnik średnioważony wyposażenia infrastrukturalnego dla sieci drogowej w buforach wokół miast województwa łódzkiego

\begin{tabular}{|l|l|l|l|l|l|l|l|}
\hline \multicolumn{1}{|c|}{ Miasto } & $\begin{array}{c}\text { Wskaźnik } \\
\text { średnio- } \\
\text { ważony }\end{array}$ & Miasto & $\begin{array}{c}\text { Wskaźnik } \\
\text { średnio- } \\
\text { ważony }\end{array}$ & Miasto & $\begin{array}{c}\text { Wskaźnik } \\
\text { średnio- } \\
\text { ważony }\end{array}$ & Miasto & $\begin{array}{c}\text { Wskaźnik } \\
\text { średnio- } \\
\text { ważony }\end{array}$ \\
\hline $\begin{array}{l}\text { Konstan- } \\
\text { tynów } \\
\text { Łódzki }\end{array}$ & 3,221287 & Szadek & 3,106351 & Łowicz & 3,017809 & Koluszki & 2,909177 \\
\hline $\begin{array}{l}\text { Bełcha- } \\
\text { tów }\end{array}$ & 3,216314 & Złoczew & 3,106137 & $\begin{array}{l}\text { Zduńska } \\
\text { Wola }\end{array}$ & 3,017507 & Żychlin & 2,897383 \\
\hline $\begin{array}{l}\text { Działo- } \\
\text { szyn }\end{array}$ & 3,213721 & Zgierz & 3,095558 & Pabianice & 2,994673 & Stryków & 2,885643 \\
\hline $\begin{array}{l}\text { Aleksan- } \\
\text { drów } \\
\text { Łódzki }\end{array}$ & 3,199183 & Poddębice & 3,076196 & Tuszyn & 2,989264 & Zelów & 2,868267 \\
\hline Błaszki & 3,188495 & Drzewica & 3,07199 & Łódź & 2,96519 & Głowno & 2,863249 \\
\hline $\begin{array}{l}\text { Radom- } \\
\text { sko }\end{array}$ & 3,186821 & Przedbórz & 3,053135 & $\begin{array}{l}\text { Tomaszów } \\
\text { Mazowie- } \\
\text { cki }\end{array}$ & 2,960944 & $\begin{array}{l}\text { Piotrków } \\
\text { Trybunal- } \\
\text { ski }\end{array}$ & 2,838675 \\
\hline $\begin{array}{l}\text { Lęczyca } \\
\text { Rajón }\end{array}$ & 3,18078 & Wieruszów & 3,051319 & $\begin{array}{l}\text { Skiernie- } \\
\text { wice }\end{array}$ & 2,960565 & Wolbórz & 2,819732 \\
\hline Rzgów & 3,146285 & $\begin{array}{l}\text { Krośnie- } \\
\text { wice }\end{array}$ & 3,048419 & Brzeziny & 2,949452 & Kutno & 2,805165 \\
\hline Pajęczno & 3,142458 & Sulejów & 3,04392 & Warta & 2,948103 & Łask & 2,734269 \\
\hline $\begin{array}{l}\text { Biała } \\
\text { Rawska }\end{array}$ & 3,137859 & Sieradz & 3,037264 & Wieluń & 2,936798 & $\begin{array}{l}\text { Rawa Ma- } \\
\text { zowiecka }\end{array}$ & 2,494604 \\
\hline Kamieńsk & 3,121059 & Opoczno & 3,032175 & Ozorków & 2,926617 & Uniejów & 2,358509 \\
\hline
\end{tabular}

Źródło: opracowanie własne.

znacznie większe, o czym świadczy odchylenie standardowe na poziomie 0,67. W przypadku Uniejowa, Zelowa (do obu z nich nie prowadzi linia kolejowa) oraz Bełchatowa elementy sieci kolejowej znajdują się powyżej $10 \mathrm{~km}$ od miasta. Brak elementów sieci kolejowej pomiędzy 5 i $10 \mathrm{~km}$ od miasta jest charakterystyczny dla Sieradza i Działoszyna. W przypadku Brzezin, Wolborza i Warty sieć kolejowa nie występuje w odległości do $5 \mathrm{~km}$ od granicy miasta. Wieruszów jest miastem najlepiej wyposażonym w elementy sieci drogowej w stosunku do powierzchni i liczby potencjalnych użytkowników.

Po uwzględnieniu infrastruktury tramwajowej wielkości wskaźników średnioważonych wyposażenia infrastrukturalnego dla transportu szynowego (kolejowego i tramwajowego) uległy wyraźnym zmianom. Pomimo niskich wag przypisanych poszczególnym odcinkom linii tramwajowych (oscylujących pomiędzy 0,14-0,34), ich duża gęstość wyraźnie wpływa na wyposażenie infrastruktu- 


\section{Objaśnienia}

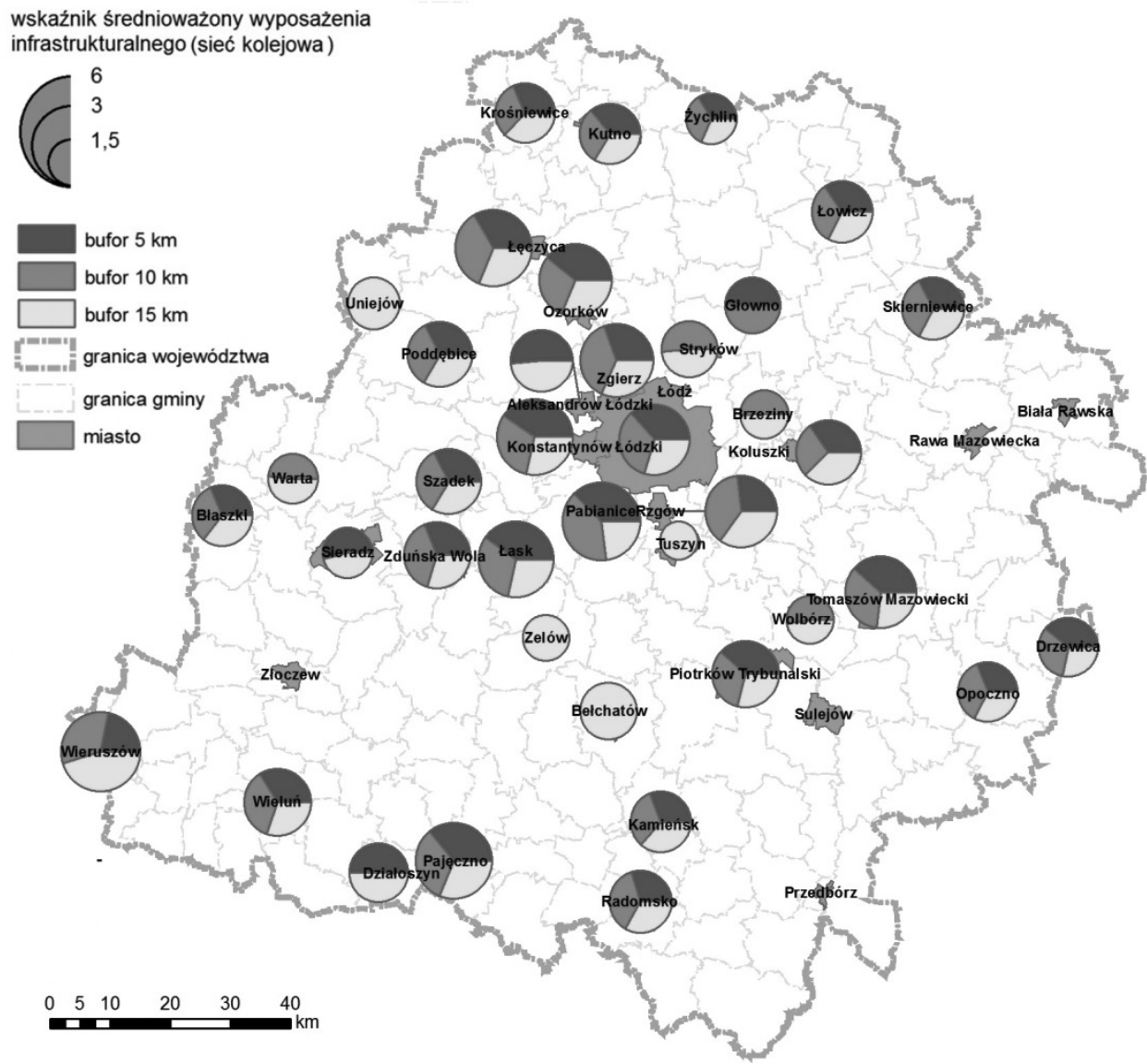

Rycina 2.28. Kolejowe wyposażenie infrastrukturalne buforów wokół miast województwa łódzkiego

Źródło: opracowanie własne

ralne. Infrastruktura tramwajowa znajduje się w buforach Ozorkowa, Zgierza, Aleksandrowa Łódzkiego, Konstantynowa Łódzkiego, Łodzi, Pabianic, Rzgowa oraz wyłącznie w najdalszym buforze Tuszyna, Łasku i Strykowa (rycina 2.29). W stosunku do liczby mieszkańców i powierzchni miasta najwyższy wskaźnik wyposażenia infrastrukturalnego dotyczy Rzgowa. Najniższym średnioważonym wskaźnikiem dla transportu tramwajowego charakteryzuje się Łódź. Największa gęstość linii tramwajowych znajduje się właśnie w granicach Łodzi, a zgodnie z przyjętą metodą badania nie jest dla niej istotna. Niski wskaźnik jest też związany z bardzo dużą liczbą potencjalnych użytkowników i powierzchnią miasta. Włączenie do analizy wyposażenia szynowego infrastruktury tramwajowej spo- 
wodowało znaczne zwiększenie zróżnicowania pomiędzy wskaźnikami dla poszczególnych miast (współczynnik zmienności wyniósł 71\%). Wskaźniki średnio odchylają się od średniej o 1,56. Najwyższym wskaźnikiem odznacza się w tym ujęciu Aleksandrów Łódzki, który przy analizie jedynie infrastruktury kolejowej plasował się na 20 miejscu. Trzeba jednakże pamiętać, o lokalnym zakresie funkcjonowania sieci tramwajowej. Zróżnicowanie wyposażenia pomiędzy poszczególnymi buforami dla całej zbiorowości miast jest nieznacznie mniejsze, gdyż średnio odchyla się o 0,64. Najmniejsze różnice w wyposażeniu dotyczą Radomska (suma wartości bezwzględnych z różnic pomiędzy buforem 5- i 10-kilometro-

\section{Objaśnienia}

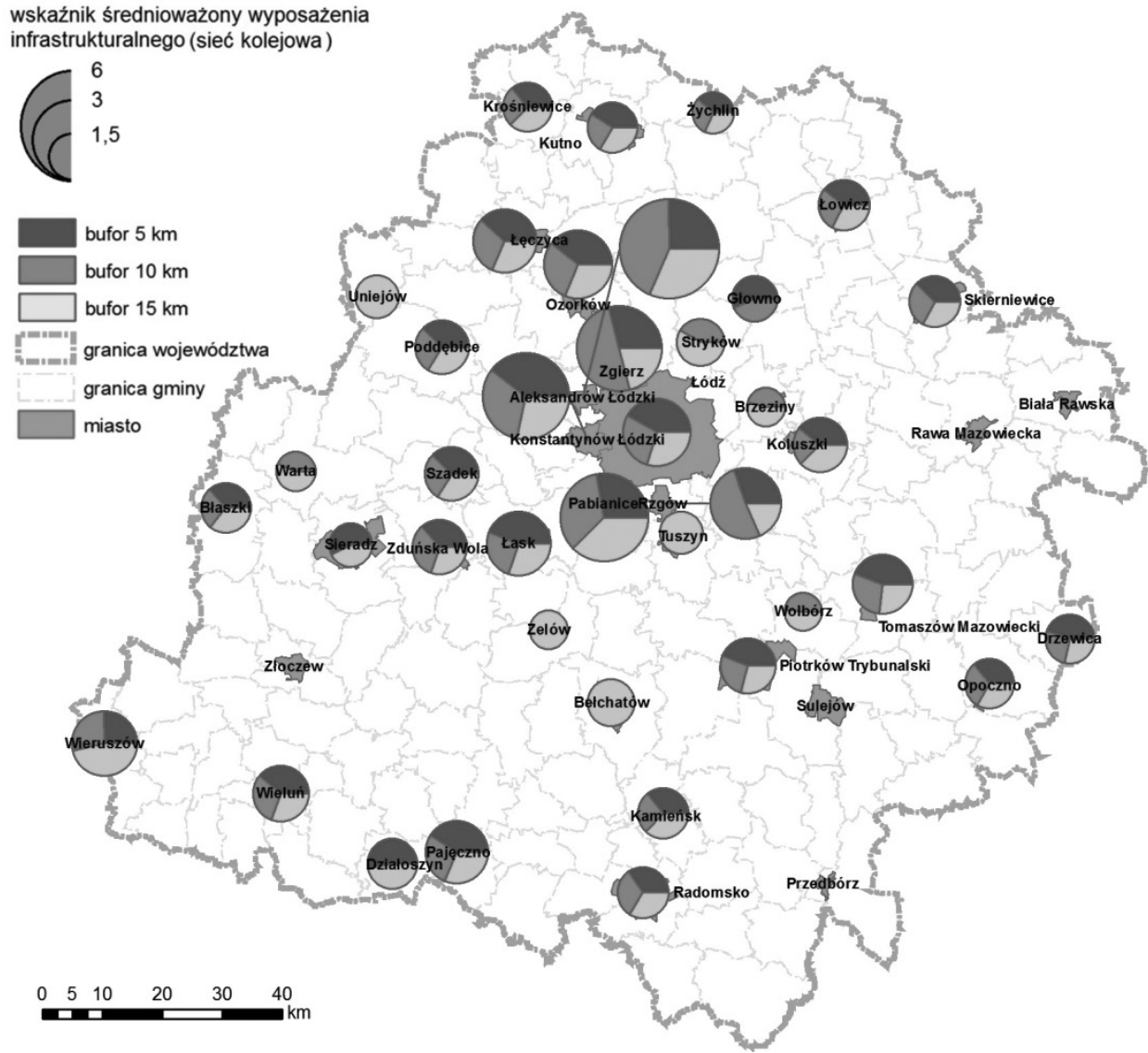

Rycina 2.29. Kolejowe i tramwajowe wyposażenie infrastrukturalne buforów wokół miast województwa łódzkiego

Źródło: opracowanie własne 
wym oraz 10- i 15-kilometrowym wynosi 0,09). Największe zróżnicowanie pomiędzy buforami dotyczy Zgierza $(2,74)$.

W celu uzupełnienia analizy wprowadzono również syntetyczną ocenę zainwestowania infrastrukturalnego miast województwa łódzkiego, mówiącą o liczbie dróg, węzłów drogowych oraz przystanków istniejących, pozwalające dotrzeć bezpośrednio do danego miasta. Wypełnia to lukę towarzyszącą wskaźnikowi średnioważonemu. Metoda bada wyposażenie infrastrukturalne, ale nie jego układ przestrzenny. Nie różnicuje więc m.in. sytuacji, gdy droga biegnie wzdłuż granicy miasta, nie „wchodząc” do niego i gdy bezpośrednio do niego prowadzi. Dlatego też zliczono węzły autostradowe i te na drogach ekspresowych, które znajdowały się w granicach administracyjnych miast. Zliczono ponadto drogi krajowe (o nieograniczonej dostępności) i wojewódzkie, prowadzące bezpośrednio do każdego z miast. Analizę uzupełniono o liczbę stacji oraz przystanków kolejowych i tramwajowych w granicach każdego z miast, mogących wskazywać na łatwość bezpośredniego dotarcia do miasta. W przypadku sieci tramwajowej liczba miast mających dostęp do sieci tramwajowej (nawet nie bezpośredni, jak w przypadku Aleksandrowa Łódzkiego czy Tuszyna) jest niewielka i o znaczeniu lokalnym w przeciwieństwie do sieci kolejowej. Następnie dla zróżnicowania znaczenia poszczególnych elementów infrastruktury arbitralnie wprowadzono wagi (tabela 2.4).

Tabela 2.4. Wyposażenie infrastrukturalne w miastach województwa łódzkiego

\begin{tabular}{|l|c|c|c|c|c|c|c|}
\hline \multicolumn{1}{|c|}{ Miasto } & $\begin{array}{c}\text { Węzły } \\
\text { autostra- } \\
\text { dowe }\end{array}$ & $\begin{array}{c}\text { Węzly } \\
\text { „ekspre- } \\
\text { sowe" }\end{array}$ & $\begin{array}{c}\text { Drogi } \\
\text { krajowe }\end{array}$ & $\begin{array}{c}\text { Drogi } \\
\text { woje- } \\
\text { wódzkie }\end{array}$ & $\begin{array}{c}\text { Przystanki } \\
\text { i stacje } \\
\text { kolejowe }\end{array}$ & $\begin{array}{c}\text { Przystanki } \\
\text { tramwa- } \\
\text { jowe }\end{array}$ & $\begin{array}{c}\text { Suma } \\
\text { punktów }\end{array}$ \\
\hline Waga & 15 & 10 & 5 & 3 & 5 & 0,5 & 293,5 \\
\hline Łódź & 0 & 0 & 4 & 2 & 12 & 415 & 73 \\
\hline $\begin{array}{l}\text { Piotrków Try- } \\
\text { bunalski }\end{array}$ & 2 & 2 & 3 & 1 & 1 & 0 & 25 \\
\hline Pabianice & 0 & 0 & 2 & 1 & 1 & 14 & 28 \\
\hline $\begin{array}{l}\text { Tomaszów } \\
\text { Mazowiecki }\end{array}$ & 0 & 1 & 1 & 1 & 2 & 0 & 28 \\
\hline Bełchatów & 0 & 0 & 1 & 2 & 2 & 0 & 21 \\
\hline Zgierz & 0 & 0 & 2 & 1 & 2 & 10 & 28 \\
\hline Skierniewice & 0 & 0 & 1 & 2 & 1 & 0 & 16 \\
\hline Radomsko & 0 & 0 & 2 & 1 & 1 & 0 & 18 \\
\hline Kutno & 0 & 0 & 2 & 1 & 1 & 0 & 18 \\
\hline Zduńska Wola & 0 & 0 & 1 & 0 & 2 & 0 & 15 \\
\hline Sieradz & 0 & 0 & 3 & 2 & 4 & 0 & 41 \\
\hline Łowicz & 0 & 0 & 4 & 2 & 2 & 0 & 36 \\
\hline Wieluńn & 0 & 0 & 3 & 2 & 2 & 0 & 31 \\
\hline
\end{tabular}


Tabela $2.4(\mathrm{~cd}$.

\begin{tabular}{|c|c|c|c|c|c|c|c|}
\hline Miasto & $\begin{array}{c}\text { Węzły } \\
\text { autostra- } \\
\text { dowe }\end{array}$ & $\begin{array}{l}\text { Węzły } \\
\text { „ekspre- } \\
\text { sowe” }\end{array}$ & $\begin{array}{c}\text { Drogi } \\
\text { krajowe }\end{array}$ & $\begin{array}{c}\text { Drogi } \\
\text { woje- } \\
\text { wódzkie }\end{array}$ & $\begin{array}{c}\text { Przystanki } \\
\text { i stacje } \\
\text { kolejowe }\end{array}$ & \begin{tabular}{|c}
$\begin{array}{c}\text { Przystanki } \\
\text { tramwa- } \\
\text { jowe }\end{array}$ \\
\end{tabular} & \multirow[t]{2}{*}{$\begin{array}{c}\text { Suma } \\
\text { punktów }\end{array}$} \\
\hline Waga & 15 & 10 & 5 & 3 & 5 & 0,5 & \\
\hline Opoczno & 0 & 0 & 1 & 2 & 2 & 0 & 21 \\
\hline $\begin{array}{l}\text { Aleksandrów } \\
\text { Łódzki }\end{array}$ & 0 & 0 & 2 & 0 & 0 & 0 & 10 \\
\hline Ozorków & 0 & 0 & 1 & 2 & 1 & 5 & 18,5 \\
\hline Łask & 0 & 0 & 2 & 3 & 2 & 0 & 29 \\
\hline $\begin{array}{l}\text { Konstantynów } \\
\text { Łódzki }\end{array}$ & 0 & 0 & 1 & 1 & 0 & 11 & 13,5 \\
\hline $\begin{array}{l}\text { Rawa Mazo- } \\
\text { wiecka }\end{array}$ & 0 & 2 & 1 & 3 & 1 & 0 & 39 \\
\hline Łęczyca & 0 & 0 & 1 & 1 & 1 & 0 & 13 \\
\hline Głowno & 0 & 0 & 1 & 0 & 1 & 0 & 10 \\
\hline Koluszki & 0 & 0 & 0 & 2 & 1 & 0 & 11 \\
\hline Brzeziny & 0 & 0 & 1 & 3 & 0 & 0 & 14 \\
\hline Wieruszów & 0 & 0 & 1 & 1 & 2 & 0 & 18 \\
\hline Żychlin & 0 & 0 & 0 & 2 & 1 & 0 & 11 \\
\hline Zelów & 0 & 0 & 0 & 1 & 0 & 0 & 3 \\
\hline Poddębice & 0 & 0 & 1 & 1 & 1 & 0 & 13 \\
\hline Tuszyn & 0 & 0 & 1 & 0 & 0 & 0 & 5 \\
\hline Pajęczno & 0 & 0 & 1 & 0 & 0 & 0 & 5 \\
\hline Sulejów & 0 & 0 & 2 & 1 & 0 & 0 & 13 \\
\hline Działoszyn & 0 & 0 & 1 & 2 & 1 & 0 & 16 \\
\hline Krośniewice & 0 & 0 & 2 & 1 & 0 & 0 & 13 \\
\hline Drzewica & 0 & 0 & 0 & 1 & 1 & 0 & 8 \\
\hline Przedbórz & 0 & 0 & 1 & 1 & 0 & 0 & 8 \\
\hline Stryków & 1 & 0 & 1 & 1 & 1 & 0 & 28 \\
\hline Złoczew & 0 & 0 & 2 & 0 & 0 & 0 & 10 \\
\hline Rzgów & 0 & 0 & 2 & 1 & 0 & 0 & 13 \\
\hline Warta & 0 & 0 & 1 & 1 & 0 & 0 & 8 \\
\hline Biała Rawska & 0 & 0 & 0 & 1 & 1 & 0 & 8 \\
\hline Uniejów & 0 & 0 & 1 & 2 & 0 & 0 & 11 \\
\hline Kamieńsk & 0 & 0 & 1 & 1 & 1 & 0 & 13 \\
\hline Wolbórz & 0 & 1 & 0 & 0 & 0 & 0 & 10 \\
\hline Błaszki & 0 & 0 & 1 & 2 & 1 & 0 & 16 \\
\hline Szadek & 0 & 0 & 0 & 2 & 1 & 0 & 11 \\
\hline
\end{tabular}

Źródło: opracowanie własne na podstawie danych udostępnionych przez GDDKiA oddział Łódź, PKP Polskie Linie Kolejowe S.A., Zarząd Dróg i Transportu w Łodzi. 
Zdecydowanie najlepiej wyposażonym pod tym względem miastem jest Łódź. Wynika to przede wszystkim z bardzo licznych przystanków tramwajowych. Najniższą pozycję w powyższej klasyfikacji zajmuje Zelów, posiadając jedynie dostęp do jednej drogi wojewódzkiej. W aktualnej sieci drogowej tylko Piotrków Trybunalski oraz Stryków mają w swoich granicach węzeł autostradowy. Również Piotrków Trybunalski i trzy inne jednostki posiadają wjazdy i zjazdy z dróg ekspresowych. 



\section{DOSTĘPNOŚĆ TRANSPORTOWA MIAST W ŚWIETLE TRANSPORTU ZBIOROWEGO}

\subsection{Organizacja transportu zbiorowego w województwie lódzkim}

Należy wyraźnie podkreślić, że warunkiem sine qua non zapewnienia dostępności transportowej danego miasta jest zorganizowanie odpowiedniego dostępu do elementów infrastruktury, ale również do usług przewozowych. Te dwa elementy są ze sobą ściśle związane, ponieważ korzystanie z usług jest niemożliwe bez odpowiednio łatwego dostępu do infrastruktury. Z drugiej zaś strony nawet możliwie łatwy i powszechny dostęp do niej nie gwarantuje dostępności transportowej na pożądanym poziomie. Maksymalny poziom dostępności różnorodnych, użytecznych miejsc, dóbr, osób i usług, często znacznie od siebie oddalonych, uzależniony jest poza samym dostępem do transportu, również od posiadania innych elementów (np. środków pieniężnych) przyczyniających do dotarcia do tychże miejsc, osób czy usług. Transport umożliwia jedynie dotarcie do miejsca docelowego, nie skupia się jednak na wykorzystaniu wspomnianych dóbr, usług, miejsc pracy czy edukacji dostępnych w miejscu docelowym podróży (Diagnoza polskiego transportu 2011).

Transport zbiorowy odgrywa niezwykle ważną rolę w strukturze przewozów osobowych w przeważającej liczbie krajów. W tych o niższym poziomie rozwoju i o niskim wskaźniku motoryzacji, jak również w tych wysoko rozwiniętych, gdzie transport zbiorowy jest konkurencyjny pod względem ekonomicznym i czasowym, stanowiąc substytut dla transportu indywidualnego (Bartosiewicz, Marszał 2011).

Szybki rozwój transportu indywidualnego po 1990 r. w połączeniu z niską rentownością funkcjonujących w tamtym czasie firm transportowych, powstałych w czasie gospodarki nakazowo-rozdzielczej, przyczynił się do ważnych przemian w sektorze transportu. Zmiany dotyczyły m.in. redukcji liczby połączeń w transporcie zbiorowym przejmowanych przez transport indywidualny, reorganizacji i prywatyzacji przedsiębiorstw przewozowych oraz dynamicznego powstawania nowych firm.

Wynikiem procesów ekonomizacji transportu było ograniczenie szeregu połączeń w transporcie zbiorowym na trasach słabo uczęszczanych, przy jednoczes- 
nym dynamicznym rozwoju przewozów tam, gdzie tego typu działalność przynosi największe zyski. Tendencja ta zrozumiała z ekonomicznego punktu widzenia, spowodowała ograniczoną dostępność do położonych peryferyjnie obszarów wiejskich (i często również charakteryzujących się niskim, na tle kraju, wskaźnikiem motoryzacji) (ibid.).

Organizacja transportu zbiorowego w województwie łódzkim jest typowa dla całej Polski. Przewozy pasażerskie są realizowane przez spółki PKS, prywatnych przewoźników typu bus, gminne spółki przewozowe (typu Miejskie Przedsiębiorstwo Komunikacyjne w Łodzi), Przewozy Regionalne, PKP InterCity oraz Łódzką Kolej Aglomeracyjną. W świetle przeprowadzonych badań najważniejszą rolę w strukturze przewozów odgrywają połączenia zapewniane przez spółki PKS. Operatorzy ci obsługują największą liczbę połączeń, obejmując swoim zasięgiem największy obszar województwa. Największa liczba połączeń jest realizowana pomiędzy największymi miastami regionu oraz wzdłuż najważniejszych szlaków komunikacyjnych (głównie dróg krajowych). Na terenie województwa łódzkiego spółki PKS zlokalizowane są w 13 miastach. Są to firmy powstałe z państwowych przedsiębiorstw działających do początku lat dziewięćdziesiątych ubiegłego wieku. Przeważająca część z nich to firmy prywatne, przede wszystkim spółki pracownicze, a niektóre należą do samorządów lub państwa. Przedsiębiorstwa te swoje siedziby zlokalizowały w największych miastach regionu: Łodzi, Piotrkowie Trybunalskim, Skierniewicach, Zduńskiej Woli, Sieradzu, Tomaszowie Mazowieckim, Radomsku, Bełchatowie, Kutnie, Łowiczu, Łęczycy, Wieluniu oraz Opocznie.

Większość z przewoźników świadczy połączenia o charakterze lokalnym, przede wszystkim w obrębie jednego powiatu. Realizowane są również (chociaż w mniejszym stopniu) połączenia o zasięgu regionalnym (głównie do Łodzi). Niektóre z przedsiębiorstw komunikacji samochodowej proponują ponadto połączenia krajowe, przede wszystkim nastawione na dojazd do większych miast województwa czy też miejscowości turystycznych. Najbogatszą ofertę przewozów posiadają spółki PKS z Łodzi oraz innych większych ośrodków miejskich (Sieradz, Skierniewice, Piotrków Trybunalski) (ibid.). Przedsiębiorstwo komunikacji samochodowej w Łodzi oferuje połączenia przede wszystkim do stolicy regionu wzdłuż głównych dróg wylotowych, w kierunku Głowna, Brzezin, Ujazdu, Tuszyna, Łasku, Lutomierska, Poddębic oraz Łęczycy. Są to w większości kursy o zasięgu regionalnym.

W każdym przypadku, w typowy dzień powszedni, jest to przynajmniej kilkanaście kursów na dobę. Natomiast pozostali wymienieni przewoźnicy pełnią istotną rolę w obsłudze ważniejszych szlaków komunikacyjnych. Są to przede wszystkim połączenia między Łodzią i wymienionymi miastami. Bardzo istotne dla części kierunków jest funkcjonowanie kursów dalekobieżnych, realizowanych jednoczenie w trybie połączeń przyśpieszonych lub pospiesznych, co pociąga za sobą pewne konsekwencje. Autobusy zatrzymują się bowiem znacznie rzadziej, jedynie na niektórych przystankach. Podwyższają zatem dostępność transportową zazwyczaj 
większych ośrodków województwa. Uzupełnieniem oferty przedstawionej przez przewoźników PKS z regionu łódzkiego są kursy realizowane przez przedsiębiorstwa zlokalizowane w miastach województw sąsiadujących z łódzkim. Obsługują one $\mathrm{w}$ większości jedynie tereny przygraniczne województwa łódzkiego. W większości przypadków miejscowości gminne położone przy granicy województwa są przystankiem końcowym dla takich kursów. W niektórych przypadkach skutkuje to tym, że dany obszar jest lepiej skomunikowany z miastami z innego województwa niż tego, do którego należy administracyjnie. Przez obszar regionu łódzkiego prowadzi również wiele linii autobusów dalekobieżnych obsługiwanych przez spółki PKS z całego kraju. Ich rolę w organizacji transportu zbiorowego województwa można oceniać dwojako. Znacząca jest w przypadku połączeń pomiędzy miastami, bowiem autobusy zazwyczaj zatrzymują się wyłącznie na ich terenie'. Połączenia dalekobieżne są jednak mało znaczące w ujęciu lokalnym ${ }^{2}$. Autobusowe kursy międzynarodowe wykonywane są przez prywatne firmy przewozowe: Eurolines Polska, Zawadzkie, Orbis Transport, Delta Travel, Polski Bus, Eurobus, Polska Service, Polonia Transport, Ecolines, Comfort Lines (Paczkowski, Budler 2012).

Drugą grupę przewoźników stanowią prywatne firmy oferujące przewozy typu bus (w niektórych przypadkach kursy są realizowane również przez autobusy). Są to firmy posiadające swoje siedziby w regionie łódzkim, przeważnie obsługujące co najwyżej jedną bądź dwie trasy, dysponujące maksymalnie kilkunastoma pojazdami. Regularne przewozy pasażerskie są w przypadku tych firm zazwyczaj podstawowym rodzajem działalności. Niektóre poszerzają swoją ofertę o przewozy nieregularne (np. turystyczne). W granicach województwa łódzkiego działa około 80 przewoźników tego typu. Obsługują one głównie trasy, na których zapotrzebowanie na usługi transportowe jest największe, a ich zasięg przestrzenny jest mocno ograniczony. Przewozy świadczone przez prywatnych przewoźników typu bus są najpowszechniejsze w szeroko rozumianej aglomeracji łódzkiej. Przedsiębiorcy oferują połączenia na trasach pomiędzy Łodzią a miejscowościa-

${ }^{1}$ Spośród przedsiębiorstw komunikacji samochodowej, największą liczbę linii lokalnych obsługują: PKS w Łodzi Sp. z o.o., PKS w Zduńskiej Woli Sp. z o.o., PKS w Sieradzu Sp. z o.o., PKS w Bełchatowie Sp. z o.o., PKS w Wieluniu Sp. z o.o., PKS w Radomsku Sp. z o.o., PKS w Częstochowie Sp. z o.o., PKS w Piotrkowie Trybunalskim Sp. z o.o., PKS w Opocznie Sp. z o.o., PKS w Końskich Sp. z o.o., PKS w Tomaszowie Mazowieckim Sp. z o.o., PKS w Skierniewicach Sp. z o.o., PKS w Grójcu Sp. z o.o., PKS w Łęczycy Sp. z o.o., PKS w Turku Sp. z o.o., PKS w Koninie Sp. z o.o., PKS w Gostyninie Sp. z o.o., PKS w Płocku Sp. z o.o., PKS w Mławie Sp. z o.o. oraz PKS w Kutnie Sp. z o.o.

${ }^{2}$ Mieszkańcy mogą korzystać z kursów dalekobieżnych zatrzymujących się w miastach województwa, które są wykonywane przez: PKS w Łodzi Sp. z o.o., PKS we Wrocławiu Sp. z o.o., PKS w Kielcach Sp. z o.o., PKS w Kamiennej Górze Sp. z o.o., PKS w Jędrzejowie Sp. z o.o., PKS w Busku Zdroju Sp. z o.o., PKS w Rzeszowie Sp. z o.o., PKS w Opolu Sp. z o.o., PKS we Włocławku Sp. z o.o., PKS w Zamościu Sp. z o.o., PKS w Ostrowcu Świętokrzyskim Sp. z o.o., PKS w Puławach Sp. z o.o., PKS w Radomiu Sp. z o.o., PKS w Warszawie Sp. z o.o., PKS w Inowrocławiu Sp. z o.o., PKS w Białymstoku Sp. z o.o. oraz PKS w Słupsku Sp. z o.o. 
mi w sąsiednich powiatach, po ważniejszych szlakach komunikacyjnych, takich jak: Łódź-Pabianice, Łódź Konstantynów Łódzki, Łódź-Aleksandrów ŁódzkiPoddębice-Uniejów，Łódź-Zgierz-Ozorków，Łódź-Stryków-Głowno-Łowicz, Łódź-Andrespol-Rokiciny-Tomaszów Mazowiecki, Łódź-Rzgów-Tuszyn. W wielu przypadkach trasy są obsługiwane przez kilku przewoźników, często przewozy typu bus stanowią przeważającą formę transportu publicznego. Drugą strefą o dużym udziale przewozów typu bus jest region piotrkowski. W większości przypadków są to kursy realizowane pomiędzy siedzibami poszczególnych gmin powiatu a Piotrkowem Trybunalskim lub też Piotrkowem Trybunalskim i Bełchatowem, Radomskiem oraz Tomaszowem Mazowieckim. Tak efektywnie funkcjonujące przewozy busami nie występują w żadnym innym obszarze województwa łódzkiego. Ograniczone są zazwyczaj do pojedynczych relacji, o niewielkiej liczbie połączeń w ciągu doby.

Znacznie mniejszą rolę w organizacji transportu zbiorowego odgrywają miejskie (gminne) spółki komunikacyjne, odpowiadające zazwyczaj jedynie za połączenia o charakterze lokalnym (w granicach danej jednostki gminnej). Spośród 17 tego typu przewoźników ${ }^{3}$ jedynie kilku oferuje relacje na dłuższych trasach niż teren danej gminy (wyłączając z tego połączenia o charakterze podmiejskim, obejmujące teren gminy wiejskiej o tej samej nazwie co miasto, np.: połączenia autobusowe relacji miasto Zduńska Wola - gmina wiejska Zduńska Wola czy miasto Kutno - gmina wiejska Kutno). Najbardziej rozbudowaną ofertę posiada spółka MPK w Łodzi oferująca zarówno połączenia autobusowe, jak i tramwajowe (Kowalski, Wiśniewski 2013). Łódzka sieć tramwajowa jest jedną z czternastu sieci tramwajowych w Polsce, a szerokość jej toru wynosi $1000 \mathrm{~mm}$. Obsługuje ona następujące jednostki administracyjne: m. Łódź, m. Pabianice, m. Konstantynów Łódzki, m. Zgierz, gm. Zgierz, m. Ozorków, gm. Lutomiersk, gm. Ksawerów. Obecnie eksploatowanych jest 17 linii tramwajowych kursujących w granicach Łodzi oraz 5 linii tramwajowych łączących Łódź z miastami (gminami) ościennymi (linia 16 do Zgierza, linia 41 do Pabianic, linia 9 do Konstantynowa, linia 43 do Lutomierska, linia 46 do Zgierza i Ozorkowa). W związku z przejęciem Spółki z o.o. „Tramwaje Podmiejskie” przez MPK-Łódź Sp. z o.o., łódzka linia tramwajowa nr 9 do Konstantynowa Łódzkiego zastąpiła dotychczasową linię 43 bis (Paczkowski, Bulder 2012). Do 31 marca 2012 r. komunikacja tramwajowa prowadzona była przez 3 przedsiębiorstwa: MPK-Łódź Sp. z o.o. należąca w pełni do Miasta Łodzi, obsługująca wszystkie linie tramwajowe miejskie oraz linię 11 do Zgierza i Pabianic, Spółka z o.o. MKT (Międzygminna Komunikacja Tramwajowa) będąca współwłasnością obsługiwanych gmin, obsługująca linię tramwajową do Ozorkowa oraz Spółka z o.o. TP (Tramwaje Podmiejskie) również będąca współ-

${ }^{3}$ W Lodzi, Piotrkowie Trybunalskim, Pabianicach, Tomaszowie Mazowieckim, Bełchatowie, Zgierzu, Skierniewicach, Radomsku, Kutnie, Zduńskiej Woli, Sieradzu, Łowiczu, Opocznie, Łasku, Żychlinie, Wieluniu i Głownie. 
własnością obsługiwanych gmin, zapewniająca transport pomiędzy Konstantynowem Łódzkim i Lutomierskiem. Od 1 kwietnia 2012 tramwajowe usługi komunikacyjne świadczone są tylko i wyłącznie przez MPK-Łódź Sp. z o.o. W skład sieci tramwajowej wchodzą 23 krańcówki tramwajowe, z czego 5 położonych jest poza miejskim obszarem Łodzi (pętle tramwajowe w Lutomiersku, Konstantynowie Łódzkim, Pabianicach, Ozorkowie oraz Zgierzu) (ibid.). Rozwój tej gałęzi transportu w ostatnich latach w Łodzi wiązał się ściśle z realizacją Łódzkiego Tramwaju Regionalnego (ŁTR) (Feltynowski 2009). Celem uruchomienia ŁTR była poprawa powiązań komunikacyjnych między rdzeniem ŁOM a Pabianicami i Zgierzem na łącznym odcinku $28 \mathrm{~km}$. W początkowej fazie projektu przewidywano ponadto włączenie do systemu linii prowadzącej do Ozorkowa. Jednakże zaniechano realizacji projektu w takim kształcie. Dlatego też w ramach dotychczasowej realizacji projektu tramwaju regionalnego znacznie poprawiono jedynie stan infrastruktury technicznej na terenie Łodzi oraz zakupiono nowoczesny tabor. Kolejne działania miały skupić się na ujednoliceniu taryf przewozowych oraz wdrożeniu elektronicznej karty miejskiej wraz z systemem informacji dla pasażera na temat całego systemu transportu zbiorowego (Pielesiak 2012).

Narastające trudności napotyka funkcjonowanie tramwajowej linii podmiejskiej między Zgierzem a Ozorkowem, z której korzystają głównie uczniowie szkół oraz osoby dojeżdżające do pracy. Infrastruktura na tym odcinku jest poważnie niedoinwestowana, co skutkuje licznymi i istotnymi ograniczeniami prędkości. Utrudnienia w ruchu chociażby jednego pojazdu powodują nieterminowy przyjazd następnych tramwajów, co wynika z konieczności korzystania wyłącznie z linii jednotorowej z mijankami. Tak niekorzystną sytuację może poprawić jedynie gruntowny remont torowiska, na to jednak zgodę wyrazić muszą wszystkie zaangażowane w przedsięwzięcie samorządy gminne. Problemy występowały również w związku z połączeniem Łódź-Pabianice. W tym przypadku nieporozumienie dotyczyło wielkości udziałów w kosztach przewozów oraz cen biletów, wynikających z umowy pomiędzy miastem Pabianice a zarządzającym linią łódzkim MPK. Brak porozumienia między stronami mógł skutkować koniecznością rozpisania przetargu na obsługę połączeń tramwajowych, a w pesymistycznym scenariuszu również całkowitą likwidacją linii tramwajowej i wprowadzeniem na jej miejsce połączeń autobusowych (ibid.). Finalnie jednak postanowiono zachować wszystkie funkcjonujące podmiejskie linie tramwajowe. W 2012 r. ujednolicono na nich taryfy biletowe, dzięki czemu bez wątpienia poprawił się komfort przemieszczania się między rdzeniem obszaru metropolitalnego a jego zapleczem. Takiego rozwiązania nie zaimplementowało dotychczas kilku komunalnych przewoźników autobusowych, obsługujących ruch w obrębie podłódzkich miast oraz gmin ościennych. Dla przykładu komunikacja miejska w Pabianicach obejmuje swoim zasięgiem gminy: Ksawerów, Dobroń, Rzgów oraz gminę wiejską Pabianice. Przewoźnicy ci stosują jednakże własne taryfy biletowe, nieuprawniające do kontynuowania podróży z ważnym biletem MPK Łódź. 
Osiemnaście linii autobusowych wychodzi poza granicę administracyjną miasta Łodzi i dodatkowo dociera do: Zgierza, Skotnik, Imielnika, Dobrej, Strykowa, Kalonki, Skoszewa, Natolina, Brzezin, Andrespola, Stróży, Ludwikowa, Rzgowa, Gadki Starej, Niesięcina oraz Aleksandrowa Łódzkiego. Ponadto jedna linia zarządzana jest przez przewoźnika ze Zgierza i kończy swój bieg przy Dworcu Łódź Kaliska. W przypadku przewoźników z innych miast województwa są to przede wszystkim pojedyncze połączenia pomiędzy miastem powiatowym i terenem gmin $\mathrm{z}$ tego powiatu lub też pomiędzy sąsiadującymi ze sobą miastami powiatowymi. Połączenia tego rodzaju są realizowane przez miejskie spółki transportowe, m. in. z Radomska, Łasku, Pabianic, Zgierza oraz Kutna. Ponadto w dwóch gminach wiejskich województwa funkcjonują komunalne spółki przewozowe. Są to: Kleszczów, gdzie przewoźnik zapewnia połączenie z Bełchatowem, oraz Brójce, w przypadku których zorganizowano regularne połączenia $\mathrm{z}$ Łodzią.

System transportu zbiorowego w regionie łódzkim uzupełniają przewozy kolejowe. Należy jednak pamiętać, że ich rola i zasięg przestrzenny są jednoznacznie uwarunkowane przebiegiem linii kolejowych. Ponadto przewozy pasażerskie są realizowane nie na wszystkich funkcjonujących liniach kolejowych. Na trasach Kępno-Wieruszów-Wieluń-Herby Nowe, Tomaszów Mazowiecki-DrzewicaPrzysucha-Radom oraz na Magistrali Węglowej ruch pociągów pasażerskich jest niewielki. Pasażerskie przewozy kolejowe, ważne z punktu widzenia regionalnego transportu publicznego, są realizowane na trasach: Łódź-Sieradz, Łódź-Kutno oraz Łódź-Koluszki (Piotrków Trybunalski-Radomsko)-Skierniewice. Są one realizowane przez spółkę Przewozy Regionalne (zamawiane przez Urząd Marszałkowski w Łodzi w postaci pociągów regionalnych i InterRegio), która odpowiedzialna jest przede wszystkim za regionalne połączenia osobowe na trasach wymienionych powyżej. Pociągi tego przewoźnika zatrzymują się na wszystkich stacjach na danej trasie, co ma kluczowe znaczenie dla dostępności w ujęciu lokalnym. Połączenia kolejowe realizuje również spółka PKP IC, która odpowiedzialna jest za połączenia pośpieszne ponadregionalne. Znaczenie transportu kolejowego w województwie łódzkim w porównaniu do jego roli w innych regionach kraju jest wyraźnie mniejsze. Zaledwie przez niewielką część gmin województwa przebiegają linie kolejowe, ponadto zdarza się, że ich trasowanie nie odpowiada współczesnemu charakterowi sieci osadniczej. Stacje i przystanki w wielu przypadkach są zlokalizowane w dużym oddaleniu od centrów miejscowości, utrudniając tym samym swobodne korzystanie z transportu kolejowego. Dodatkowo, problemem jest wspominany już układ sieci kolejowej w samej Łodzi. Rozwiązaniem sprzyjającym efektywnemu funkcjonowaniu dwóch jednakowo ważnych w obsłudze ruchu kolejowego stacji, niebędących jednak w bezpośrednim powiązaniu, jest budowa linii kolei średnicowej. Inwestycja infrastrukturalna połączona z przeprojektowaniem systemu zarządzania siecią połączeń regionalnych, przygotowująca ją do włączenia kolei dużych prędkości (Massel 2008), powinna skutkować wytworzeniem węzła kolejowego nastawionego na obsługę ruchu tranzytowego (Pielesiak 2012). Zmianę niekorzyst- 
nej sytuacji może przynieść również uruchomienie Łódzkiej Kolei Aglomeracyjnej. Towarzysząca mu modernizacja infrastruktury oraz zwiększenie liczby miejsc zatrzymania taboru powinny przyczynić się do rozwoju systemu transportowego regionu, a także spowodować przemiany w strukturze przewozów w obszarze szeroko rozumianej aglomeracji łódzkiej. W 2010 r. utworzona została Łódzka Kolej Aglomeracyjna Sp. z. o.o., będąca podmiotem samorządu województwa łódzkiego, której celem jest zapewnienie efektywnej organizacji pasażerskiego ruchu kolejowego w regionie łódzkim oraz prawidłowe jego funkcjonowanie. Spółka przygotowała projekt Budowa systemu Łódzkiej Kolei Aglomeracyjnej, wpisany na listę projektów indywidualnych 7.3-19. W ramach projektu zakupionych zastanie docelowo 20 sztuk nowych elektrycznych pociągów oraz w rejonie stacji Łódź Widzew wybudowany zostanie obiekt pełniący rolę zaplecza technicznego dla taboru. Przedsięwzięcie zakłada budowę nowego systemu transportu kolejowego, który połączy miasta aglomeracji łódzkiej. Kursy realizowane będą pomiędzy stacją Łódź Kaliska a Pabianicami, Łaskiem, Zduńską Wolą i Sieradzem po linii nr 14. Po linii nr 15 kolej aglomeracyjna będzie kursować pomiędzy Łodzią Kaliską, Zgierzem, Głownem i Łowiczem. Trzeci kierunek obejmuje Łódź Widzew, Zgierz oraz Kutno (linia nr 16). Kolej aglomeracyjna łączyć będzie również Łódź Fabryczną z Koluszkami (linia nr 17). Ostatnia relacja nie będzie wykraczać poza granice Łodzi, bowiem połączy stację Łódź Kaliska ze stacjami na Chojnach i Widzewie (linia nr 25/540). W dalszej perspektywie kolej ma również docierać do miast poza granicami województwa łódzkiego. Regularna poprawa dostępności miast objętych przyszłą koleją aglomeracyjną nastąpi po zrealizowaniu przez PKP PLK S.A. wspomnianego projektu, w tym utworzeniu intermodalnych przystanków z Łódzką Koleją Aglomeracyjną. W ramach pierwszego etapu przewiduje się budowę pasażerskich węzłów multimodalnych, przebudowę istniejących i budowę 8 nowych przystanków (Paczkowski, Budler 2012).

W momencie zakończenia inwestycji kolejowych dotyczących łódzkiego węzła, docierające do niego linie będą prawdopodobnymi źródłami wprowadzającymi ruch pasażerów w jego granicach. Problematyczne wtedy może okazać się niedoinwestowanie połączeń pomiędzy centrum województwa a największymi miastami regionu, takimi jak Piotrków Trybunalski i Bełchatów. Jest to szczególnie ważne ze względu na występującą w ostatnim okresie wyraźną urbanizację terenów zlokalizowanych na południowy zachód od Łodzi. Znaczenie tego obszaru jest niemałe, m.in. ze względu na lokalizację dużego zespołu handlowego (C.H. Ptak, Polros i Ptak Outlet).

Organizacja transportu zbiorowego, chociaż w różnych częściach województwa łódzkiego charakteryzuje się różną efektywnością działania, to zapewnia w minimalnym stopniu spójność wszystkich 44 miast regionu. Zróżnicowanie sprawności działania przewoźników odpowiedzialnych za przewozy pasażerskie i jej wpływ na dostępność transportową każdego z miast została szczegółowo przeanalizowana $\mathrm{w}$ dalszej części rozdziału. 


\subsection{Powiązania miast województwa lódzkiego w systemie transportu zbiorowego}

Punktem wyjścia do oceny dostępności transportowej miast województwa łódzkiego w świetle transportu zbiorowego jest założenie, że badaniu poddana jest dostępność w ujęciu wewnątrzregionalnym. Oznacza to, że niniejsze opracowanie nie podejmuje tematyki dotyczącej powiązań wynikających z funkcjonowania transportu zbiorowego w relacjach ponadregionalnych. Dla mieszkańca województwa łódzkiego, z punktu widzenia codziennych przejazdów, kluczową rolę pełni stosownie do potrzeb rozwinięta komunikacja zbiorowa, pozwalająca na dojazdy do pracy i placówek oświatowych oraz korzystanie z infrastruktury społecznej, która nie występuje w miejscu zamieszkania (Bartosiewicz, Marszał 2011).

Ocena dostępności prowadzona była w oparciu o połączenia pomiędzy wszystkimi możliwymi dla danego środka transportu, parami miast województwa łódzkiego. Analizę wykonano, biorąc pod uwagę pięć podstawowych zmiennych: liczbę połączeń, ich długość, koszt i czas przejazdu oraz rodzaj przewoźnika (wielkość i struktura przewozów nie mogły zostać poddane analizie ze względu na brak dostępu do informacji o charakterze handlowym). Pierwszą zmienną badawczą, czyli liczbę połączeń określono poprzez zliczenie kursów danego środka transportu $\mathrm{w}$ dniu roboczym $\mathrm{z}$ włączeniem kursów przyspieszonych oraz pośpiesznych. Nie włączano do analizy połączeń, których koniec przypadał na dzień po rozpoczęciu podróży. Połączenie jest rozumiane jako pojedynczy kurs wykonywany dowolnym środkiem transportu zbiorowego pomiędzy ostatnim z przystanków w granicach administracyjnych miasta początkowego podróży a pierwszym przystankiem w graniach miasta docelowego podróży. W relacjach bilateralnych pomiędzy miastami połączenia zliczano jednokrotnie. Taki dobór zmiennej został podyktowany faktem, że liczba połączeń wychodzących z danego miasta i liczba połączeń przychodzących pokrywają się ze sobą (jeżeli występują różnice, to są one nieistotne). W ten sposób jedno połączenie jest rozumiane jako pojedyncza relacja obsługująca kurs pomiędzy miastami w obie strony. W przypadku połączeń realizowanych pociągiem i tramwajem analizowano zarówno połączenia bezpośrednie, jak i z przesiadkami. W związku z charakterystyką sieci kolejowej i tramwajowej województwa łódzkiego oraz ograniczoną ofertą przewoźników, substytucyjność połączeń pomiędzy poszczególnymi miastami jest stosunkowo niewielka, zatem do analizy włączono wszystkie możliwe relacje. Biorąc pod uwagę połączenia autobusowe, w badaniu uwzględniono jedynie połączenia bezpośrednie. W ich przypadku bardzo wysoka substytucyjność wynika z szerokiej oferty przewoźników oraz niemalże braku determinacji trasy podróży przez znacznie bardziej rozbudowaną sieć drogową. Próba określenia kompletnej liczby połączeń (niezależnie od ich bezpośredniości) mogłaby być obarczona wysokim błędem z uwagi chociażby na często teoretyczne (ustalane arbitralnie przez au- 
tora) miejsca przesiadek, których możliwość jest znacznie szersza niżeli w przypadku połączeń kolejowych czy tramwajowych. W celu ustalenia liczby oraz innych szczegółów połączeń kolejowych wykorzystano dane udostępnione przez PKP PLK oraz TK Telekom w formie zdigitalizowanych rozkładów jazdy oraz informacji zawartych w serwisie http://www.rozklad-pkp.pl/. W przypadku połączeń tramwajowych źródłem danych były informacje zawarte w serwisie internetowym Miejskiego Przedsiębiorstwa Komunikacyjnego w Lodzi (http://www. mpk.lodz.pl/). Najszerszy zakres źródeł został wykorzystany do ustalenia charakterystyki przewozów autobusowych i busowych. Sięgnięto do danych udostępnionych przez Wydział Transportu Drogowego Urzędu Marszałkowskiego w Łodzi. Uzupełniono je o informacje pochodzące ze stron internetowych poszczególnych przewoźników oraz z serwisu internetowego Polskiej Izby Gospodarczej Transportu Samochodowego i Spedycji (http://autobusowyrozkladjazdy.pl/). W przypadku braku informacji w powyższych źródłach wykonywano badania terenowe w celu uzyskania rozkładów jazdy bezpośrednio od przewoźników, z tabliczek przystankowych lub urzędów miast czy placówek usługowych (najczęściej sklepów) zlokalizowanych blisko przystanku.

Drugą poddaną analizie zmienną była odległość fizyczna rzeczywista pomiędzy poszczególnymi miastami przy założeniu poruszania się transportem zbiorowym. Po naniesieniu trasy przejazdu na mapę, dokonywano pomiarów odległości zgodnie z przedstawioną wcześniej metodologią. Uzyskane wyniki posłużyły na pogrzeby badania zakresu przestrzennego oddziaływania komunikacji zbiorowej, a także jako wyznacznik oporu przestrzeni dla obliczanego w dalszej części rozdziału potencjału komunikacyjnego miast.

Trzecia zmienna określająca poziom dostępności transportowej miast województwa łódzkiego w świetle komunikacji zbiorowej to czas przejazdu. Ta cecha ma w niniejszym badaniu znaczenie decydujące, bowiem w pierwszej kolejności determinowała wybór konkretnego, analizowanego pod innymi względami, połączenia. Przyjęto założenie, że podróżujący, wybierając połączenie, kieruje się przede wszystkim kryterium czasu. Przy wyborze połączenia do analizy kierowano się następującym kluczem. W pierwszej kolejności wybierano połączenie, które umożliwi najszybsze przemieszczenie się z jednego do drugiego miasta (w przypadku podróży pociągiem i tramwajem czas przejazdu był ważniejszy od pojawiającej się konieczności przesiadki). Jeśli występowały połączenia o identycznym czasie realizacji, wybierano to, które nie zmuszało do przesiadki. Gdy te dwie cechy nie różnicowały połączeń, wówczas kierowano się kryterium kosztu podróży - niższa cena stanowiła element decydujący. Jako ostatnią zmienną różnicującą wybrano odległość, która ma zostać pokonana przy wyborze konkretnego połączenia. Jednakże ma ona wyłącznie charakter teoretyczny, bowiem w badaniu nie wystąpiła konieczność porównywania połączeń pod tym względem.

Kolejną zmienną charakteryzującą połączenia między miastami jest koszt przejazdu. Do badania przyjęto założenie zakupu możliwie najtańszego biletu 
normalnego jednorazowego, umożliwiającego dotarcie do pierwszego przystanku w granicach administracyjnych miasta docelowego. W przypadku połączeń kolejowych przyjęto zakup biletu drugiej klasy.

Ostatnia cecha mówiąca o poziomie rozwoju połączeń komunikacji zbiorowej w sieci miast województwa łódzkiego to zróżnicowanie przewoźników oferujących usługi na poszczególnych trasach. Jak już wspomniano, na obszarze województwa łódzkiego usługi przewozowe świadczą spółki PKS, prywatni przewoźnicy typu bus, gminne spółki przewozowe (typu MPK), Przewozy Regionalne oraz PKP InterCity ${ }^{4}$. Na potrzeby analizy wszystkie powyżej przedstawione zmienne ukazano w podziale na przewoźników. W przypadku połączeń kolejowych i tramwajowych przyporządkowanie jest jednoznaczne i dotyczy odpowiednio Przewozów Regionalnych i PKP InterCity oraz Miejskiego Przedsiębiorstwa Komunikacyjnego w Łodzi. W odniesieniu do połączeń samochodowych występuje większa konkurencja. W analizie dokonano różnicowania w taki sposób, że jeśli tę samą relację obsługiwał przewoźnik PKS i BUS, to dokonywano ich agregacji, jako najbardziej do siebie podobnych. Niezależnie od zróżnicowania przewoźników na danej trasie, zawsze wydzielano do analizy połączenia realizowane przez gminne spółki przewozowe, ujęte w dalszej części pracy jako lokalny transport zbiorowy (LTZ), ze względu na ich nieco inny charakter.

Badanie dostępności transportowej miast województwa łódzkiego w zakresie transportu zbiorowego zostało przeprowadzone w marcu, kwietniu i maju $2014 \mathrm{r}$.

Dostępność do transportu zbiorowego warunkuje poprawny, wszechstronny rozwój na danym obszarze. Umożliwia sprawne przemieszczanie się między miejscem zamieszkania a miejscem pracy lub nauki. Dobrze zorganizowany transport zbiorowy, o odpowiedniej częstotliwości i rozkładzie kursów w ciągu dnia, przyczynia się do zmniejszenia kongestii w ruchu kołowym i skraca czas przejazdu. Przed przystąpieniem do analizy połączeń bilateralnych pomiędzy miastami województwa łódzkiego konieczne jest scharakteryzowanie sieci połączeń w transporcie zbiorowym w ujęciu topologicznym. W przypadku transportu samochodowego do badania zostały włączone wszystkie 44 miasta, ponieważ do każdego z nich istnieje możliwość dotarcia dzięki sieci dróg. Zdecydowanie najlepiej dostępnym miastem pod względem bezpośrednich połączeń autobusowych/busowych jest Łódź. Spośród wszystkich miast województwa jedynie z Wolborza nie jest możliwe dotarcie do Łodzi bezpośrednim połączeniem. Ponadto każda z pozostałych 42 relacji do Łodzi ma charakter połączeń zwykłych (rycina 3.1).

Drugi pod względem ilości połączeń bezpośrednich jest Piotrków Trybunalski, natomiast ich liczba jest znacznie mniejsza (28), a do tego aż z 13 miast można dotrzeć jedynie dzięki połączeniom przyspieszonym i pośpiesznym. Wraz z Wieruszowem są ośrodkami o najliczniejszych tego typu połączeniach. Naj-

${ }^{4} \mathrm{~W}$ granicach województwa łódzkiego funkcjonują również Koleje Mazowieckie obsługujące połączenia m.in. do Skierniewic, Łowicza czy Drzewicy. 


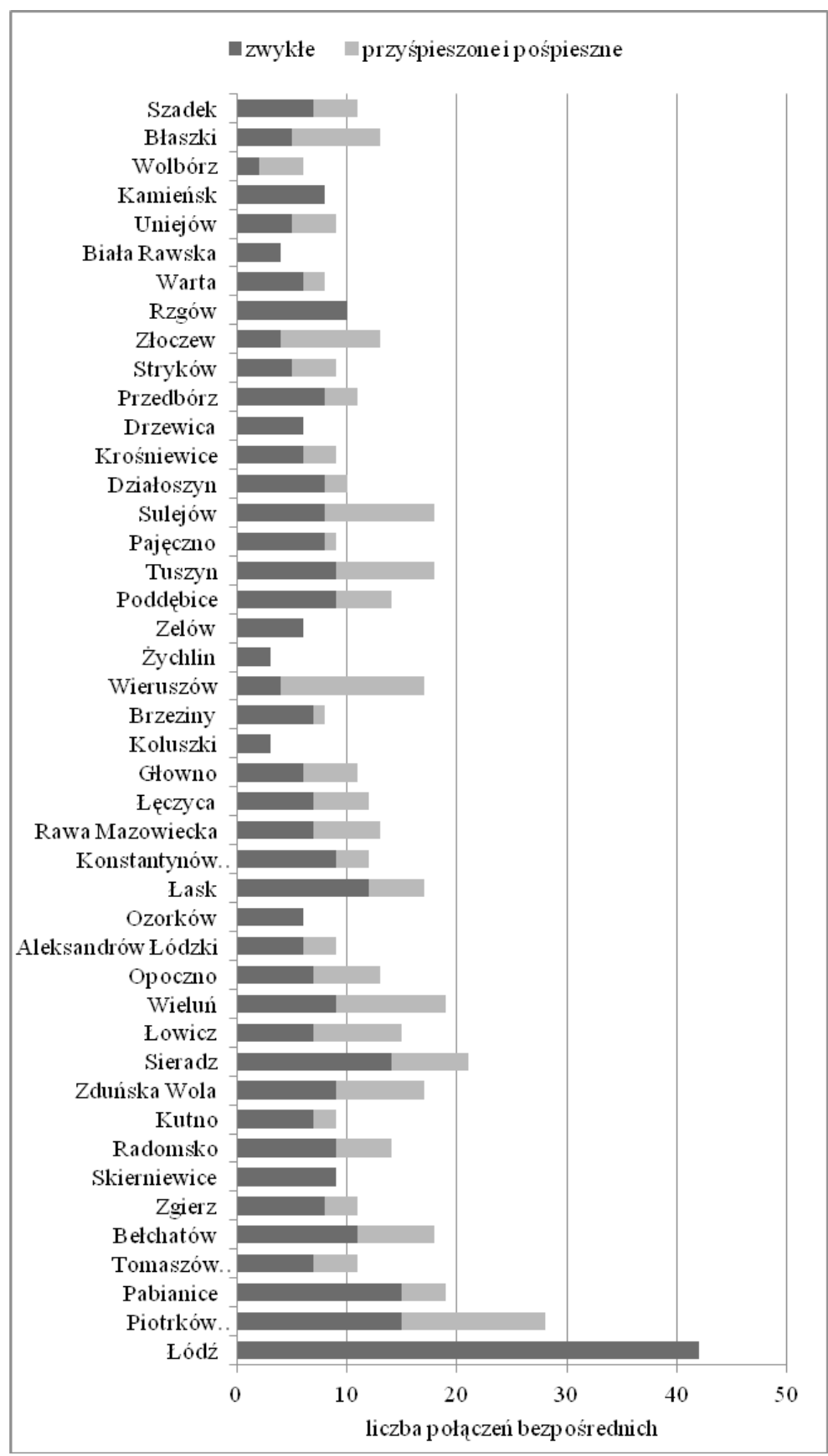

Rycina 3.1. Bezpośrednie połączenia autobusowe/busowe do miast województwa łódzkiego w podziale na zwykłe oraz przyspieszone i pośpieszne

Źródło: opracowanie własne 
większa dysproporcja na rzecz połączeń przyspieszonymi/pośpiesznymi dotyczy właśnie Wieruszowa. Przyczyny takiej sytuacji można upatrywać w peryferyjnym położeniu ośrodka w wojewódzkiej sieci drogowej, co sprzyja uruchamianiu połączeń pozwalających w krótkim czasie dotrzeć do ośrodków znacznie oddalonych. Powyżej 20 bezpośrednich połączeń posiada jeszcze jedynie tylko Sieradz (21). Aż do 17 miast województwa można dotrzeć maksymalnie z 10 innych ośrodków województwa. Najniższy poziom dostępności w świetle ilości bezpośrednich połączeń autobusowych/busowych dotyczy Koluszek i Żychlina. Posiadają jedynie połączenia do trzech innych miast. Do Koluszek możliwe jest bezpośrednie dotarcie wyłącznie z Łodzi, Rawy Mazowieckiej i Brzezin. Z Żychlina bezpośrednie połączenia prowadzą tylko do Łodzi, Zgierza oraz Kutna.

W przypadku połączeń kolejowych do analizy włączono 24 miasta (rycina 3.2). Jedynie do nich prowadzony jest regularny ruch pasażerski. W związku z założeniem wstępnym, dotyczącym włączenia do analizy zarówno połączeń bezpośrednich, jak i z przesiadkami, do każdego z miast dzięki kolei można dotrzeć z 23 innych ośrodków. Największą liczbą bezpośrednich połączeń odznacza się Łódź (18). Aby dotrzeć do niej z Wielunia, Opoczna, Wieruszowa, Żychlina oraz Kamieńska ${ }^{5}$, konieczna jest przynajmniej jedna zmiana pociągu. Więcej niż 10 połączeń bezpośrednich prowadzi jeszcze jedynie do Zgierza (13). Najniższy pod tym względem poziom dostępności charakteryzuje Wieluń, Opoczno oraz Wieruszów. Przyczyn takiej sytuacji należy przede wszystkim upatrywać w lokalizacji tych ośrodków sieci kolejowej województwa. Wieluń i Wieruszów są bezpośrednio dostępne jedynie wzajemnie. Opoczno zaś posiada bezpośrednie połączenie wyłącznie z Tomaszowem Mazowieckim. Przy ustalaniu przebiegu połączeń uwzględniających przesiadki możliwe było określenie miast, w których użytkownicy zmuszeni zostali do zmiany pociągu. Analiza rozkładu jazdy wskazuje na Łódź, jako miejsce największej liczby przesiadek. Ze wszystkich 276 kombinacji połączeń aż 105 razy Łódź pojawia się jako stacja przesiadkowa. W 59 przypadkach miejscem zmiany pociągu były Koluszki. Przewoźnik zaplanował 24 przesiadki w Tomaszowie Mazowieckim, 16 w Skierniewicach, 15 w Łowiczu, 9 w Kutnie, po 8 w Piotrkowie Trybunalskim i Zgierzu, 3 w Łęczycy oraz po 1 w Radomsku i Sieradzu. Realizacja możliwie najszybszych połączeń kolejowych pomiędzy miastami województwa łódzkiego pociąga za sobą konieczność przesiadek również w miastach poza ich granicami. Podróżując głównie do Wielunia i Wieruszowa, pasażerowie zmuszeni są do przesiadki w Ostrowie Wielkopolskim (w przypadku 20 połączeń), Częstochowie (9 połączeń), ale również w Poznaniu (7 połączeń), Lublińcu (5 połączeń), Kępnie, Kaletach i Krzepicach (po 3 połączenia) czy Miechowie, Katowicach, Sochaczewie i Jarocinie (po 1 połączeniu).

${ }^{5}$ Żychlin nie posiada bezpośredniego połączenia kolejowego. Stacja Żychlin jest zlokalizowana w Pniewie, natomiast dojazd do miasta funkcjonuje dzięki autobusom miejskim. 


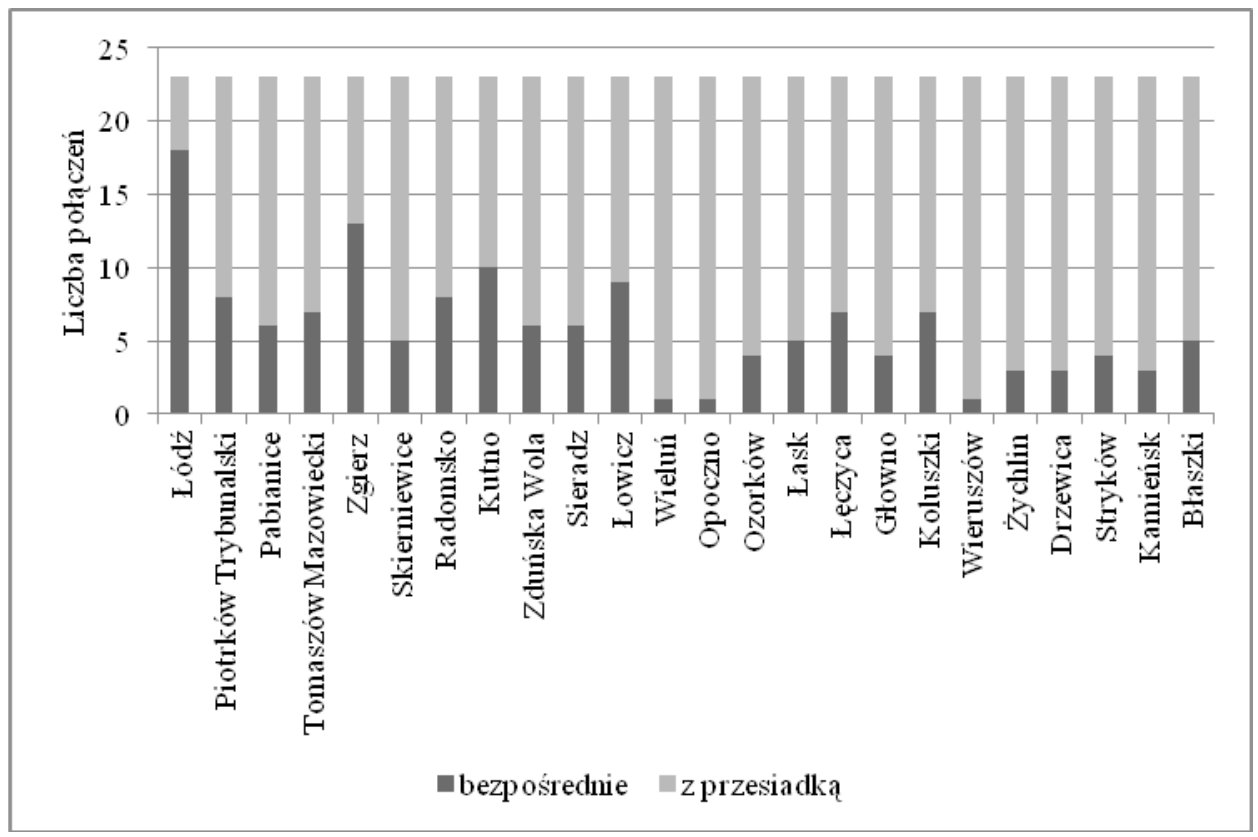

Rycina 3.2. Połączenia kolejowe do miast województwa łódzkiego w podziale na bezpośrednie oraz z przesiadką

Źródło: opracowanie własne

W przypadku połączeń tramwajowych jedynie Łódź posiada bezpośrednie połączenia z pozostałymi czterema miastami połączonymi siecią tramwajową. Układ sieci implikuje sytuację, w której Ozorków i Zgierz posiadają wzajemne bezpośrednie połączenia, zaś Pabianice i Konstantynów Łódzki mają jedynie bezpośrednie połączenia z Łodzią.

Dla oceny dostępności transportowej miast województwa łódzkiego konieczne jest zobrazowanie częstotliwości, długości, czasu, kosztu i rodzaju przewoźników w postaci macierzy przedstawiającej wszystkie możliwe połączenia bilateralne dla danej sieci transportowej.

Analizę rozpoczęto od sieci połączeń autobusowych i busowych. Biorąc pod uwagę częstotliwość połączeń, najsilniejsze relacje łączą Łódź z pozostałymi miastami obszaru metropolitalnego. Ponad 100 połączeń na dobę łączy ją wzajemnie z Pabianicami, Zgierzem, Aleksandrowem Łódzkim, Ozorkowem, Konstantynowem Łódzkim, Tuszynem oraz Rzgowem. Podkreślenia wymaga również silna relacja pomiędzy Zgierzem i Ozorkowem, które łączy ponad 170 połączeń na dobę. Nieznacznie mniej połączeń łączy Tuszyn ze Rzgowem (154).

Wymienić należy również wyraźne powiązanie Piotrkowa Trybunalskiego z Sulejowem, pomiędzy którymi realizowanych jest ponad 200 bezpośrednich połączeń dziennie. Piotrków Trybunalski jest również dobrze skomunikowany 
z Bełchatowem ( 89 bezpośrednich połączeń). Wszystkie wymienione powiązania realizowane są przez spółki PKS oraz busy, przy wsparciu lokalnego transportu zbiorowego. Niemniej jednak należy podkreślić, że tak dużo dziennych kursów to wynik funkcjonowania na najpopularniejszych trasach prywatnych przewoźników typu bus, którzy posiadając kilka/kilkanaście samochodów, obsługują najczęściej tylko jedną trasę, będąc bardzo konkurencyjną alternatywą dla pozostałych przewoźników, często również dzięki ofercie cenowej. Charakterystyczne dla powiązań miast województwa łódzkiego jest występowanie dużej liczby pojedynczych połączeń przyspieszonych i pośpiesznych stanowiących jedyne bezpośrednie połączenie pomiędzy parą miast. Są one niemalże wyłącznie realizowane przez spółki PKS. Jedynie w przypadku relacji Zduńska Wola-Opoczno, Bełchatów-Wieruszów, Wieruszów-Sulejów oraz Piotrków Trybunalski-Krośniewice ich obsługa należy do przewoźników typu bus. Największą częstotliwością połączeń o charakterze przyśpieszonym i pośpiesznym odznacza się Wieluń (aż 13 takich połączeń łączy go z Bełchatowem), zaś najwięcej połączeń tego rodzaju łączy poszczególne ośrodki z Wieruszowem. Jak już wspomniano, może to wynikać z konieczności zapewnienia efektywnych połączeń z ośrodkami peryferyjnymi, takimi jak Wieluń i Wieruszów. Odległość fizyczna rzeczywista pomiędzy miastami z punktu widzenia pasażera ma marginalne znaczenie. Ważny jest dla niego przede wszystkim czas i koszt związany z podróżą. Oczywiście obie zmienne są uzależnione w znacznym stopniu od długości drogi, natomiast dla pasażera bardziej atrakcyjną będzie oferta szybszego przemieszczenia się nawet, jeśli będzie to pociągało za sobą znaczne nadłożenie drogi. Niemniej jednak ze względu na analizę dostępności transportowej w świetle efektywności funkcjonowania transportu zbiorowego, badanie odległości jest jak najbardziej zasadne. Rzecz jasna, najdłuższe relacje dotyczą Wielunia oraz Wieruszowa ze względu na ich położenie w granicach województwa i sieci drogowej. Pomimo jednych z największych odległości fizycznych rzeczywistych, dzielących je od pozostałych ośrodków, posiadają liczne połączenia bezpośrednie. Ogólnie rzecz ujmując, odległości połączeń dla poszczególnych miast zwiększają się wraz z ich oddaleniem od centrum województwa. Zależność ta nie jest tak wyraźna, jak chociażby w przypadku analiz grafowych wyposażenia infrastrukturalnego. Wśród połączeń bezpośrednich dominują bowiem te prowadzące do miast będących fizycznie najbliżej ośrodka stanowiącego miejsce rozpoczęcia podróży. Jeśli występuje połączenie do miasta znacznie oddalonego, to ma zazwyczaj charakter pośpieszny i realizowane jest nocą. Charakterystyczne jest również, że najdłuższe trasy obsługiwane są wyłącznie przez przewoźników PKS. Porównanie długości tras zgodnie z rozkładem jazdy transportu zbiorowego z odległościami fizycznymi rzeczywistymi pomiędzy poszczególnymi parami miast pozwala określić stopień wydłużenia drogi. Najwyższa dysproporcja występuje w przypadku relacji Łódź-Zduńska Wola (2,02). Podobnie wysoki stosunek odległości zgodnej z trasą autobusu do odległości fizycznej rzeczywistej charakteryzuje połączenie 
Tuszyna z Kamieńskiem $(1,9)$ oraz Pabianic i Konstantynowa Łódzkiego $(1,89)$. Odległości pomiędzy miastami w znacznej mierze warunkują czas konieczny do ich pokonania. Zaburzenia tej zależności wynikają z indywidualnych preferencji każdego z przewoźników, które wpływają na prędkość pokonywania trasy, liczbę przystanków pomiędzy miejscem rozpoczęcia i zakończenia podróży itd. Dlatego też najdłuższy czas przejazdu dotyczy również Wieruszowa, natomiast sprawnie funkcjonujący transport zbiorowy spowodował zmniejszenie peryferyjności Wielunia. Znacznie gorzej dostępne pod względem czasu przejazdu są takie ośrodki, jak: Opoczno, Rawa Mazowiecka, Krośniewice i Przedbórz. Spośród wszystkich relacji bezpośrednich pomiędzy miastami województwa łódzkiego, najszybciej dzielący dystans pokonywany jest pomiędzy Bełchatowem a Wieluniem, gdzie średnia prędkość przekracza nieznacznie $80 \mathrm{~km} / \mathrm{h}$ (jest to połączenie pośpieszne jedynie z dwoma przystankami pośrednimi). Nieco powyżej $68 \mathrm{~km} / \mathrm{h}$ porusza się autobus PKS, realizując najszybsze bezpośrednie połączenie pomiędzy Łodzią i Zduńską Wolą. Średnia prędkość $60 \mathrm{~km} / \mathrm{h}$ jest przekraczana nieznacznie również na trasie Wieluń-Wieruszów. Najniższa prędkość eksploatacyjna występuje na trasie Łódź-Tuszyn, nieznacznie przekraczając $15 \mathrm{~km} / \mathrm{h}$. Wynika to z dużej liczby przystanków pośrednich oraz wielu elementów zaburzających płynność ruchu w postaci m.in. skrzyżowań z sygnalizacją świetlną, zjazdów na posesje, które zwiększają prawdopodobieństwo włączania się pojazdów do ruchu. Ponadto autobusy i busy na trasie Łódź-Tuszyn poruszają się po drodze krajowej nr 1, która wprowadzając ruch od Łodzi, od południa charakteryzuje się bardzo wysokim natężeniem pojazdów (zgodnie z Generalnym Pomiarem Ruchu z 2010 r. średni dobowy ruch pojazdów wyniósł na tym odcinku ponad 29 tys. pojazdów, a prognozy Generalnej Dyrekcji Dróg Krajowych i Autostrad mówią, że aktualny ruch jest niemal o $12 \%$ wyższy).

Ostatnią z poddanych analizie zmiennych jest koszt przejazdu. Obok czasu stanowi najważniejszy element warunkujący wybór użytkowników transportu zbiorowego. Jest on w dużej mierze podyktowany odległością, w przypadku bowiem przewoźników PKS, prywatnych przewoźników typu bus oraz niektórych lokalnych przewoźników lokalnego transportu zbiorowego cena biletu jest wprost proporcjonalna do pokonanej odległości. Wzrost ceny następuje w pewnych, przyjętych arbitralnie przez przewoźnika, przedziałach odległości. Inne sposoby naliczania opłat skupiają się na czasie przejazdu lub też są to bilety jednoprzejazdowe (m.in. bilet aglomeracyjny MPK Łódź). Spośród bezpośrednich połączeń autobusowych i busowych pomiędzy miastami województwa łódzkiego, najdroższe w przeliczeniu na $1 \mathrm{~km}$ są połączenia pomiędzy Łodzią a najbliższymi jej (pod względem odległości fizycznych) miastami - Zgierzem, Aleksandrowem Łódzkim, Konstantynowem Łódzkim oraz Rzgowem. Nie mniej niż 1 zł za km podróżni zmuszeni są zapłacić również, podróżując bezpośrednio ze Zgierza do Aleksandrowa Łódzkiego, z Aleksandrowa Łódzkiego do Konstantynowa Łódzkiego oraz z Tuszyna do Rzgowa. 
Najtańsze w przeliczeniu na $1 \mathrm{~km}$ połączenia nieznacznie przekraczają $0,1 \mathrm{zł}$. W relacji Stryków-Złoczew, podróżując PKS-em, stawka za $1 \mathrm{~km}$ jest najniższa i wynosi 0,11 zł. Podobnie niska stawka cechuje połączenia pomiędzy Łodzią i Zduńską Wolą $(0,14 \mathrm{zł} / \mathrm{km})$ oraz Wolborzem i Wieluniem $(0,15 \mathrm{zt} / \mathrm{km})$.

Przechodząc do analizy powiązań kolejowych, w pierwszej kolejności skupiono się na analizie częstotliwości połączeń (rycina 3.3). Najwięcej połączeń spośród 24 miast województwa łódzkiego w ciągu doby, w ujęciu topologicznym, dociera do Koluszek (351). Zaledwie 3 połączenia mniej łączą pozostałe miasta województwa ze Skierniewicami. Powyżej 300 połączeń na dobę (bezpośrednich i z przesiadką) dociera jeszcze tylko do Łodzi (334) oraz Kutna (325) i Sieradza (314). Najgorzej dostępnym miastem pod względem częstotliwości połączeń kolejowych jest Drzewica, do której w ciągu doby dociera tylko 88 pociągów pasażerskich. Poniżej 100 połączeń charakteryzuje jeszcze tylko Wieruszów (93).

Skupiając się na powiązaniach bilateralnych, należy wskazać, jako relację o największej częstotliwości kursów kolejowych, połączenie Łódź-Koluszki, które dziennie pokonuje 35 składów. Podobnie wysoka liczba kursów łączy Koluszki z Kutnem (34). Powyżej 30 połączeń na dobę łączy również Koluszki ze Skierniewicami (32). Zaledwie jedno połączenie uruchomione jest pomiędzy Opocznem a Drzewicą. Analiza częstotliwości połączeń kolejowych wskazuje na generalną prawidłowość, iż jest ona wyraźnie większa w przypadku połączeń bezpośrednich.

Najbardziej dostępnym miastem województwa łódzkiego pod względem długości połączeń kolejowych w ujęciu topologicznym jest Łódź (rycina 3.4). Funkcjonujący w rzeczywistości system połączeń czyni ośrodek bardziej dostępny niż wskazywałby na to m.in. analiza grafowa. Wysoki poziom dostępności posiada również Zgierz oraz Pabianice. Poniżej 2 tys. km dzieli od pozostałych 23 miast województwa łódzkiego jeszcze Łask (1933), Koluszki (1836) oraz Stryków (1903). Zdecydowanie najgorzej dostępnym pod względem odległości w transporcie kolejowym jest Wieruszów. Skumulowana odległość do pozostałych miast regionu, wynikająca z rozkładu jazdy, wynosi niemalże 5,8 tys. km. Prawie identyczną odległością charakteryzuje się Wieluń. Te dwa ośrodki są wyraźnie odizolowane od pozostałych 22 miast objętych siecią kolejową. Trzecim najgorzej dostępnym miastem jest Radomsko, natomiast jego odległość topologiczna jest ponad 2,5 tys. km niższa od odległości Wielunia czy Wieruszowa. Wśród połączeń bilateralnych największa odległość dzieli Wieluń i Łowicz. Ponad 420 km dzieli również Żychlin i Wieruszów. Najkrótsze połączenia (do $10 \mathrm{~km}$ ) występują pomiędzy Łodzią i Zgierzem, Łęczycą i Ozorkowem oraz Głownem i Strykowem.

Znaczne odległości do Wieruszowa i Wielunia spowodowały, iż średnia odległość, jaką zmuszony jest pokonać pociąg pomiędzy każdym z dostępnych dla kolei miast, przekroczyła nieznacznie $115 \mathrm{~km}$. Połączenia nieprzekraczające średniej długości stanowią $61 \%$ ogółu. Przy wyeliminowaniu tych dwóch ośrodków z analizy i związanych z nimi połączeń, średnia długość połączenia obniżyła się do poziomu $88,3 \mathrm{~km}$. Niecałe $50 \%$ pozostałych połączeń nie osiągnęłoby warto- 

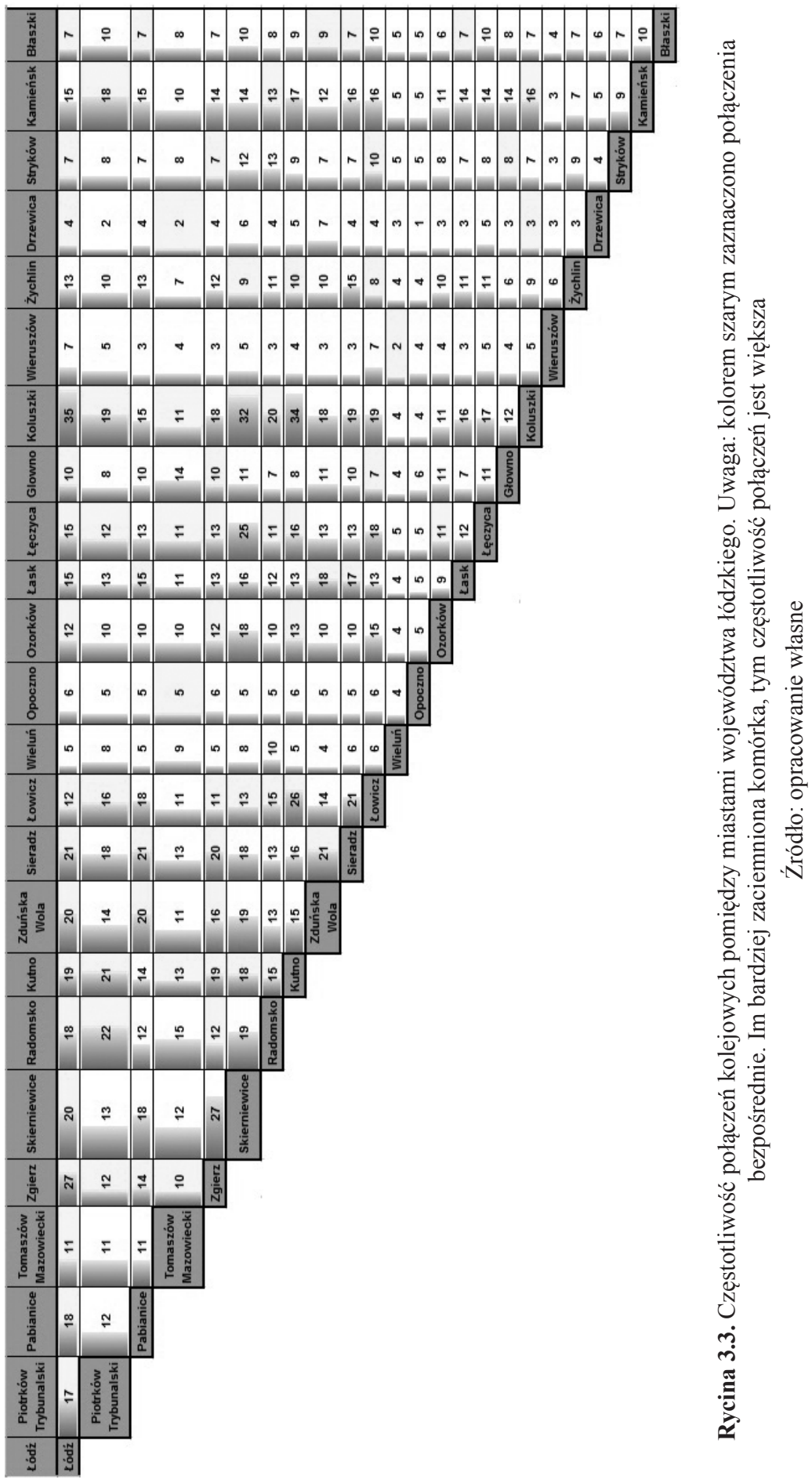


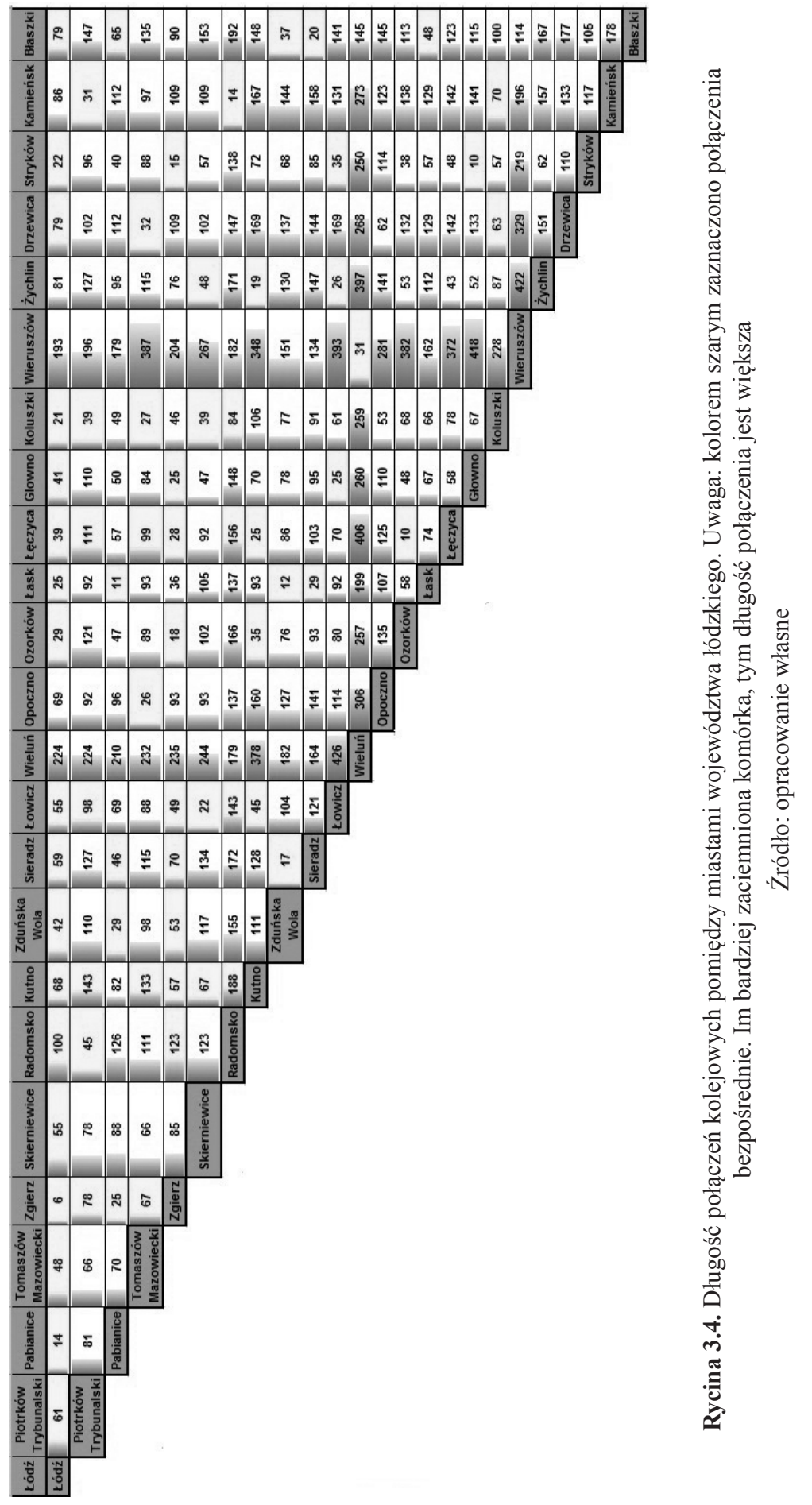


ści średniej. W przypadku połączeń kolejowych zależność pomiędzy czasem potrzebnym do przebycia odległości pomiędzy przyjętymi miastami a odległością jest jeszcze wyraźniejsza niż w odniesieniu do połączeń autobusowych. Dlatego też najniższym poziomem dostępności pod względem czasu podróży odznaczają się Wieluń i Wieruszów (rycina 3.5). Również miasta o najwyższym poziomie dostępności pod względem czasu przejazdu pokrywają się z tymi określonymi przez odległości. Przy włączeniu do analizy czasu koniecznego do przejazdu koleją pomiędzy miastami województwa łódzkiego możliwe staje się określenie prędkości na poszczególnych relacjach. $Z$ największą prędkością pociągi poruszają się pomiędzy Łowiczem i Kutnem - średnia prędkość wynosi 108 km/h. Powyżej $100 \mathrm{~km} / \mathrm{h}$ pociągi przemieszczają się również między Skierniewicami i Koluszkami. Najniższa średnia prędkość (poniżej $20 \mathrm{~km} / \mathrm{h}$ ) dotyczy relacji Opoczno-Drzewica. Średnio $30 \mathrm{~km} / \mathrm{h}$ nie przekracza również pociąg jadący pomiędzy Ozorkowem i Strykowem. Tak niewielkie średnie prędkości wynikają w dużej mierze z konieczności przesiadki w obu relacjach.

Ostatnią zmienną charakteryzującą połączenia kolejowe jest ich cena (rycina 3.6). Będąc naliczana wraz ze wzrostem odległości, nawiązuje w bezpośredni sposób do macierzy odległości.

W związku z tym, że badaniu poddano wyłącznie relacje między miastami, zmiany proporcji ceny do odległości mogą wynikać z wyboru PKP InterCity (szczególnie Express InterCity), których ceny są wyższe od tych ustalonych np. w Przewozach Regionalnych. (REGIO czy interRegio). Jednak ze względu na priorytet czasu przejazdu były często uwzględniane w niniejszej analizie. Najdroższe w przeliczeniu na $1 \mathrm{~km}$ połączenie występuje pomiędzy Łodzią i Zgierzem oraz Sieradzem i Zduńską Wolą (blisko $0,8 \mathrm{zz} / \mathrm{km}$ ). Wynika to ze stałej minimalnej stawki za bilet, która nie różnicuje połączeń do określonej długości i wyraźnie niższych cen za przejazd kolejnych kilometrów (np. przejazd $6 \mathrm{~km}$ odcinka ze stacji Łódź Żabieniec do stacji Zgierz kosztuje 4,4 zł, podczas gdy przejazd o $8 \mathrm{~km}$ dłuższego odcinka Łódź Kaliska-Pabianice kosztuje tylko 5,3 zł). Najtańsze połączenia (w przeliczeniu na $1 \mathrm{~km}$ ) łączą najbardziej oddalone od siebie miasta województwa łódzkiego. Najkorzystniejsze z punktu widzenia kosztów podróży jest poruszanie się pociągiem pomiędzy Wieluniem i Łowiczem. Cena za $1 \mathrm{~km}$ na tej trasie nie przekracza 15 gr. Niemalże identyczna cena (15,3 gr.) dotyczy relacji Drzewica-Błaszki. Ceny 0,2 zł za $1 \mathrm{~km}$ nie przekraczają łącznie 22 połączenia pomiędzy miastami województwa łódzkiego.

Ostatnim środkiem transportu zbiorowego poddanym badaniu pod względem efektywności jego funkcjonowania jest komunikacja tramwajowa. Zdecydowanie najlepiej dostępnym ośrodkiem pod względem częstotliwości połączeń tramwajowych jest Łódź (rycina 3.7a). Z pozostałymi czterema ośrodkami łączy ją ponad 240 bezpośrednich połączeń na dobę. Taką samą liczbę połączeń posiada Zgierz, natomiast obowiązujący rozkład jazdy zapewnia mu bezpośrednie połączenie tylko z Łodzią i Ozorkowem. Najgorzej skomunikowanym w tym wzglę- 

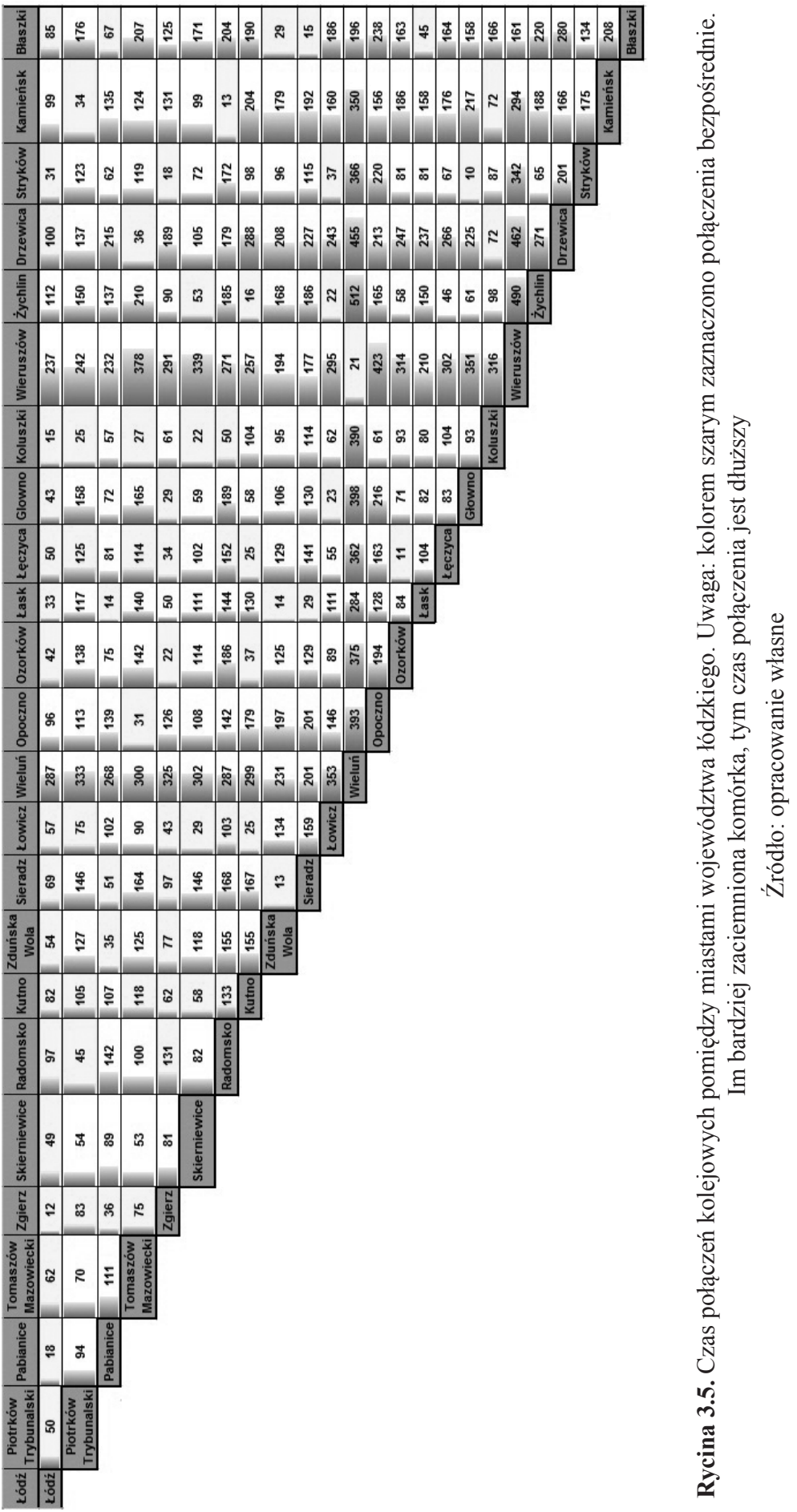


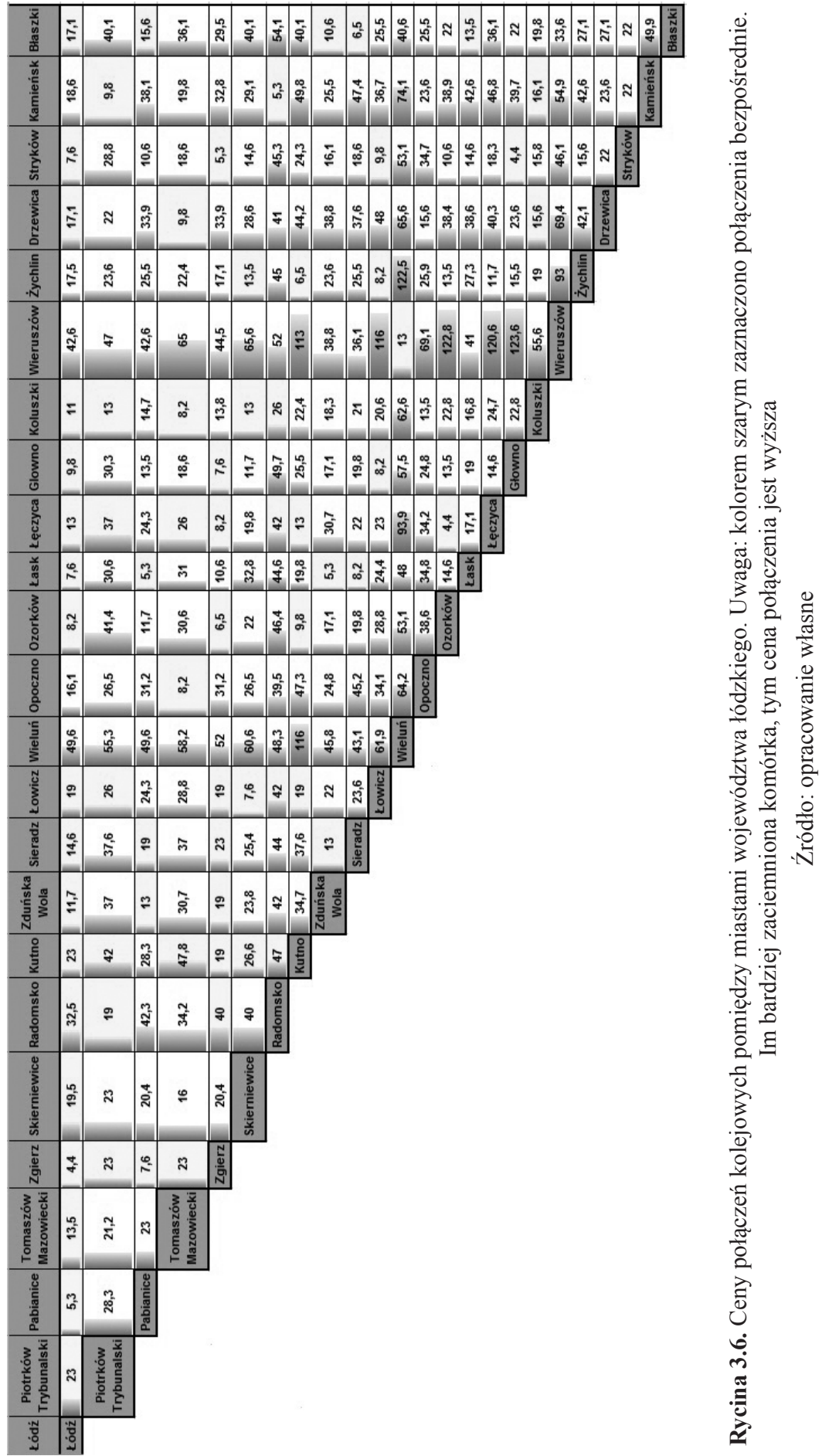


dzie miastem jest Konstantynów Łódzki, którego ilość połączeń do innych ośrodków warunkuje liczba połączeń do Łodzi, na terenie której pasażerowie muszą się przesiąść, aby dotrzeć do pozostałych ośrodków.

Zestawiając odległości (rycina 3.7d) pomiędzy pierwszymi przystankami miast objętych siecią tramwajową oraz czas potrzebny na ich pokonanie (rycina 3.7b), możliwe jest określenie średniej prędkości, z jaką poruszają się tramwaje. Najszybciej trasę pokonuje tramwaj poruszający się pomiędzy Zgierzem i Ozorkowem. Jazda w dużej mierze niezależna od ruchu drogowego i nieliczne przystanki pozwalają na podróż ze średnią prędkością niemal $24 \mathrm{~km} / \mathrm{h}$, pomimo złego stanu technicznego torowiska. Nieco powyżej $20 \mathrm{~km} / \mathrm{h}$ poruszają się tramwaje pomiędzy Łodzią i Pabianicami oraz Łodzią i Ozorkowem. Najniższa średnia prędkość jazdy dotyczy relacji Zgierz-Konstantynów Łódzki (13 km/h). Jest to w dużej mierze spowodowane koniecznością przesiadki oraz przejazdem przez Łódź, co pociąga za sobą ograniczenia w płynności ruchu spowodowane licznymi przystankami oraz skrzyżowaniami z ruchem samochodowym. Ruch zaburzają również inne tramwaje poruszające się po trasie, których częstotliwości kursowania po Łodzi są znacznie wyższe niż połączeń wychodzących poza granice miasta.

Koszt przejazdu pomiędzy poszczególnymi miastami uwarunkowany jest polityką biletową Miejskiego Przedsiębiorstwa Komunikacyjnego w Łodzi. Pasażerowie podróżujący pomiędzy Łodzią a Pabianicami, Ozorkowem oraz Konstantynowem Łódzkim oraz Ozorkowem i Zgierzem zmuszeni są do zakupienia biletu aglomeracyjnego, który uprawnia ich do przejazdu wyłącznie do końca trasy danego tramwaju. W przypadku przemieszczania się pomiędzy Pabianicami, Ozorkowem i Konstantynowem Łódzkim konieczne jest skasowanie dwóch takich biletów, brakuje bowiem połączenia tramwajowego, które w sposób bezpośredni łączyłoby owe miasta. Jedynie pomiędzy Łodzią i Zgierzem możliwy staje się przejazd przy zakupie biletów czasowych. Tak więc przejazd pomiędzy Zgierzem, Pabianicami i Konstantynowem Łódzkim jest kombinacją biletów aglomeracyjnych (jednoprzejazdowych) i czasowych.

Biorąc pod uwagę wszystkie przedstawione charakterystyki połączeń komunikacji zbiorowej pomiędzy miastami województwa łódzkiego, możliwe było określenie potencjału komunikacyjnego każdego z miast województwa oraz wskazanie sił i kierunków ciążenia komunikacyjnego (Sobczyk 1985). Zastosowany w tym celu model ciążenia wykorzystywany powszechnie w badaniach geograficzno-ekonomicznych wyraża związki analogiczne do tych, które określone zostały prawem grawitacji Newtona, mówiące, że siła przyciągania dwóch ciał jest wprost proporcjonalna do iloczynu masy tych ciał, zaś odwrotnie proporcjonalna do kwadratu odległości między nimi. Przy badaniach związanych z problematyką komunikacyjną znajduje on zastosowanie najczęściej do obliczenia obecnej bądź przyszłej wielkości przewozów pasażerskich lub towarowych. Został on już zastosowany $\mathrm{w}$ niniejszej pracy do określenia potencjału transportowo-osadniczego. W związku $\mathrm{z}$ transportem zbiorowym zasada grawitacji uwzględniona 


\begin{tabular}{|c|c|c|c|c|}
\hline Łódź & Pabianice & Zgierz & Ozorków & Konstantynów Łódzki \\
\hline Łódź & 47 & 117 & 60 & 17 \\
\hline \multirow{2}{*}{ (a) } & Pabianice & 47 & 47 & 17 \\
\cline { 3 - 5 } & & Zgierz & 60 & 17 \\
\cline { 3 - 5 } & & & Ozorków & 17 \\
\cline { 3 - 5 } & & & & Konstantynów Łódzki \\
\cline { 3 - 5 } & &
\end{tabular}

\begin{tabular}{|c|c|c|c|c|}
\hline Łódź & Pabianice & Zgierz & Ozorków & Konstantynów Łódzki \\
\hline Łódź & 11 & 2 & 45 & 3 \\
\hline \multirow{2}{*}{ (b) } & Pabianice & 80 & 108 & 66 \\
\cline { 3 - 5 } & & Zgierz & 22 & 60 \\
\cline { 3 - 5 } & & Ozorków & 113 \\
\cline { 3 - 5 } & & & & Konstantynów Łódzki \\
\cline { 3 - 5 }
\end{tabular}

\begin{tabular}{|c|c|c|c|c|}
\hline Łódź & Pabianice & Zgierz & Ozorków & Konstantynów Łódzki \\
\hline Łódź & 4,4 & 2,6 & 4,4 & 4,4 \\
\hline \multirow{2}{*}{ (c) } & Pabianice & 7,8 & 8,8 & 8,8 \\
\cline { 3 - 5 } & & Zgierz & 4,4 & 7 \\
\cline { 3 - 5 } & & Ozorków & 8,8 \\
\cline { 3 - 5 } & & &
\end{tabular}

\begin{tabular}{|c|c|c|c|c|}
\hline Łódź & Pabianice & Zgierz & Ozorków & Konstantynów Łódzki \\
\hline Łódź & 3,77 & 0,58 & 15,19 & 0,74 \\
\hline \multirow{2}{*}{ (d) } & Pabianice & 20,29 & 34,92 & 20,17 \\
\cline { 3 - 5 } & & Zgierz & 8,76 & 13,36 \\
\cline { 3 - 5 } & & Ozorków & 27,97 \\
\cline { 3 - 5 } & & & & Konstantynów Łódzki \\
\cline { 3 - 5 }
\end{tabular}

Rycina 3.7. Częstotliwość (a), czas (b), cena (c) i długość (d) połączeń tramwajowych pomiędzy miastami województwa łódzkiego. Uwaga: kolorem szarym zaznaczono połączenia bezpośrednie. Im bardziej zaciemniona komórka, tym częstotliwość, czas, cena i długość połączeń osiąga wyższe wartości Źródło: opracowanie własne

została do obliczenia wskaźnika ciążenia komunikacyjnego między każdym miastem a pozostałymi ośrodkami miejskimi układu osadniczego województwa łódzkiego. W tym celu przyjęto następujący wzór: 


$$
G_{i j}=k \frac{L_{i} L_{j}}{d_{i j}^{2}}
$$

gdzie:

$G_{i j}$ - wskaźnik grawitacji komunikacyjnej między miastami $i$ oraz $j$,

$L_{i}$ - ludność miasta $i$,

$L_{j}-$ Ludność miasta $j$,

$d_{i j}$ - odległość między miastami $i$ oraz $j$ według połączeń komunikacji zbiorowej, $k$ - współczynnik, którego wielkość równa jest pierwiastkowi kwadratowemu z częstotliwości połączeń komunikacji zbiorowej między dwoma miastami.

Zgodnie z regułą grawitacji, ciążenie między dwoma badanymi miastami jest wprost proporcjonalne do liczby ludności - potencjalnych pasażerów - tych miast, a odwrotnie proporcjonalne do kwadratu odległości między nimi. W celu przybliżenia modelu grawitacji do warunków rzeczywistych stosuje się we wzorze wykładniki potęgowe oraz współczynniki. W niniejszej pracy do wzoru na grawitację komunikacyjną wprowadzono współczynnik $k$, którego wielkość jest ściśle uzależniona od liczby połączeń autobusowych/busowych, kolejowych i tramwajowych między badanymi miastami. Spełnia on we wzorze istotną rolę, gdyż duży wpływ na siłę ciążenia między dwoma miastami ma również częstotliwość połączeń komunikacyjnych między nimi. Ze względu na duże znaczenie czasu oraz pieniędzy we współczesnym życiu społeczno-gospodarczym przyjęto, że opory przestrzeni między miastami wyrażone będą, poza jednostkami długości, również w jednostkach czasowych oraz pieniężnych zgodnie z taryfami poszczególnych przewoźników.

Najwyższy potencjał komunikacyjny w świetle połączeń autobusowych, przy przyjęciu oporu przestrzeni w jednostkach odległości, posiada Łódź. Potencjał drugiego w kolejności Zgierza jest prawie o 40\% niższy. Te dwie jednostki dość wyraźnie się wyróżniają, bowiem trzeci pod względem wielkości potencjału Konstantynów Łódzki stanowi jedynie $20 \%$ potencjału Zgierza. W związku z bardzo dużą masą Łodzi (liczbą potencjalnych pasażerów) dotyczą jej najsilniejsze relacje bilateralne, m.in. ze Zgierzem, Konstantynowem Łódzkim oraz Aleksandrowem Łódzkim. W ich przypadku siłę ciążenia zwiększa jeszcze niewielka odległość. Najniższymi potencjałami komunikacyjnymi charakteryzują się Błaszki, Drzewica oraz Biała Rawska (rycina 3.8). Przy przyjęciu jako odległości jednostek czasu, do miast o najwyższym poziomie potencjału komunikacyjnego należy włączyć Pabianice. Zmiana nie wpłynęła jednak na grupę miast o najniższym poziomie potencjału. Ulega ona niewielkim modyfikacjom przy przyjęciu odległości w jednostkach pieniężnych. Wolbórz dołączył do ośrodków, których potencjał komunikacyjny jest najniższy.

W przypadku połączeń kolejowych zmiany potencjału poszczególnych miast oraz najsilniejszych relacji towarzyszących przyjmowaniu odległości, czasu i kosztu, jako zmiennych określających oddalanie, są bardziej wyraźne. Przy za- 


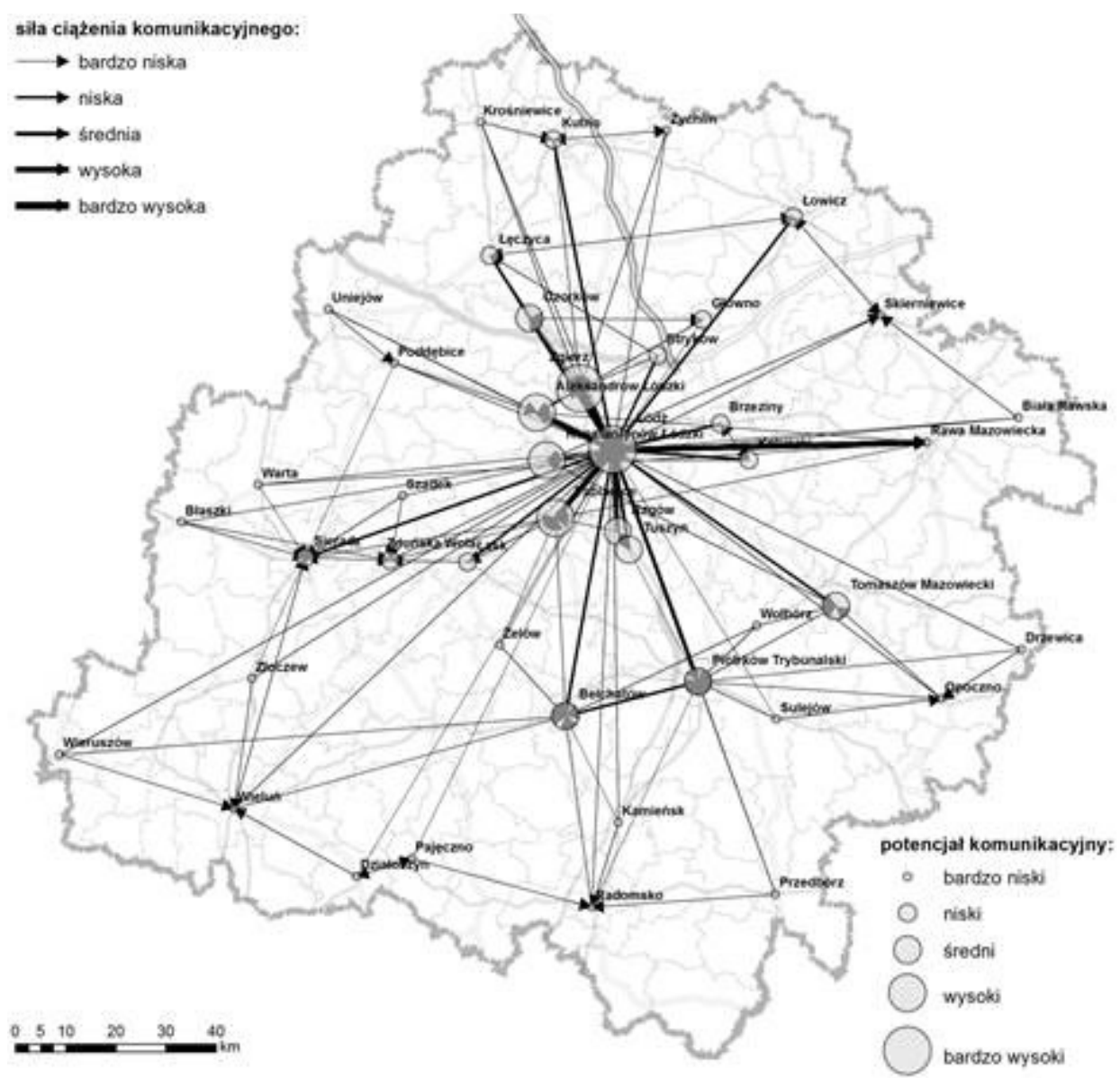

Rycina 3.8. Potencjał oraz siła i kierunek ciążenia komunikacyjnego (I, II i III rzędu) miast województwa łódzkiego w świetle komunikacji autobusowej i busowej (opór przestrzeni w jednostkach długości)

Źródło: opracowanie własne

łożeniu jednostek długości, miastami o najwyższym potencjale, tak jak w przypadku połączeń samochodowych, są: Łódź, Zgierz oraz Pabianice. Również pomiędzy tymi ośrodkami występują najsilniejsze wzajemne relacje. Uzupełnia je relacja pomiędzy Łodzią i Piotrkowem Trybunalskim. Należy podkreślić również wysoki potencjał Koluszek (rycina 3.9), które pomimo małej liczby ludności osiągnęły dziesiątą pozycję wśród 24 miast województwa. Ich potencjał jest 23-krtonie niższy od najwyższego, łódzkiego potencjału. Podczas gdy liczba ludności Łodzi jest ponad 53-krotnie wyższa od liczby mieszkańców Koluszek. 


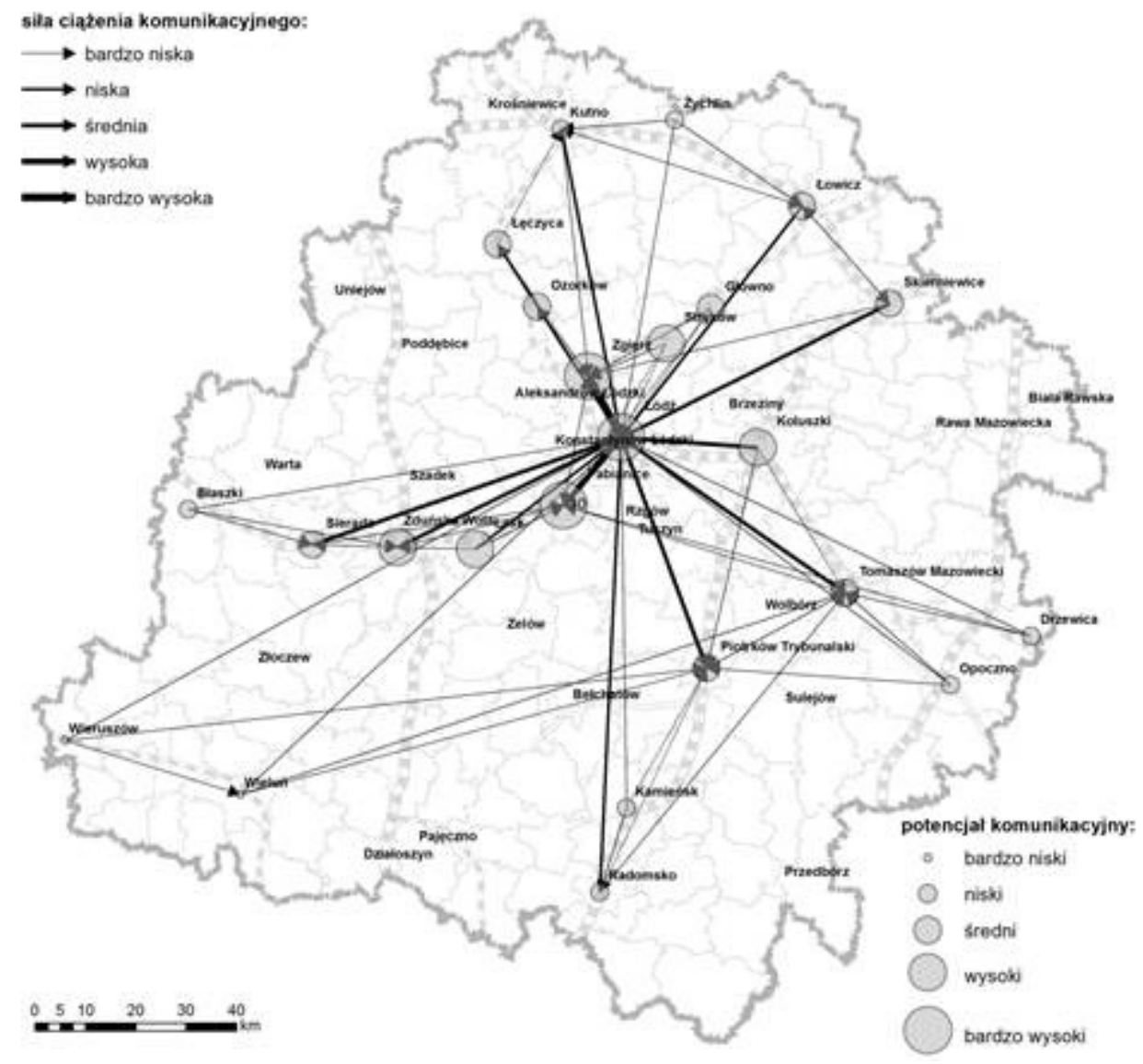

Rycina 3.9. Potencjał oraz siła i kierunek ciążenia komunikacyjnego (I, II i III rzędu) miast województwa łódzkiego w świetle komunikacji kolejowej (opór przestrzeni w jednostkach długości) Źródło: opracowanie własne

Najniższym potencjałem charakteryzują się Błaszki, Drzewica oraz Wieruszów, które poza niewielką liczbą mieszkańców charakteryzują się największymi odległościami topologicznymi. Przy ujęciu odległości w jednostkach czasowych, klasyfikacja miast pod względem ich potencjału zmienia się nieznacznie. Do grupy miast o najniższym potencjale dołączył Kamieńsk. Natomiast zwiększył się potencjał Drzewicy. Ogólnie rzecz ujmując, różnice pomiędzy potencjałami są wyraźnie mniejsze. Koluszki zachowały swoją dziesiątą lokatę, jednakże ich potencjał jest jedynie 12-krotnie mniejszy od potencjału dominującej Łodzi. Wyraźnie obniżył się potencjał miast, przez które przechodziły linie o niskich maksymalnych prędkościach, takie jak Zduńska Wola czy Zgierz (rycina 3.10). 


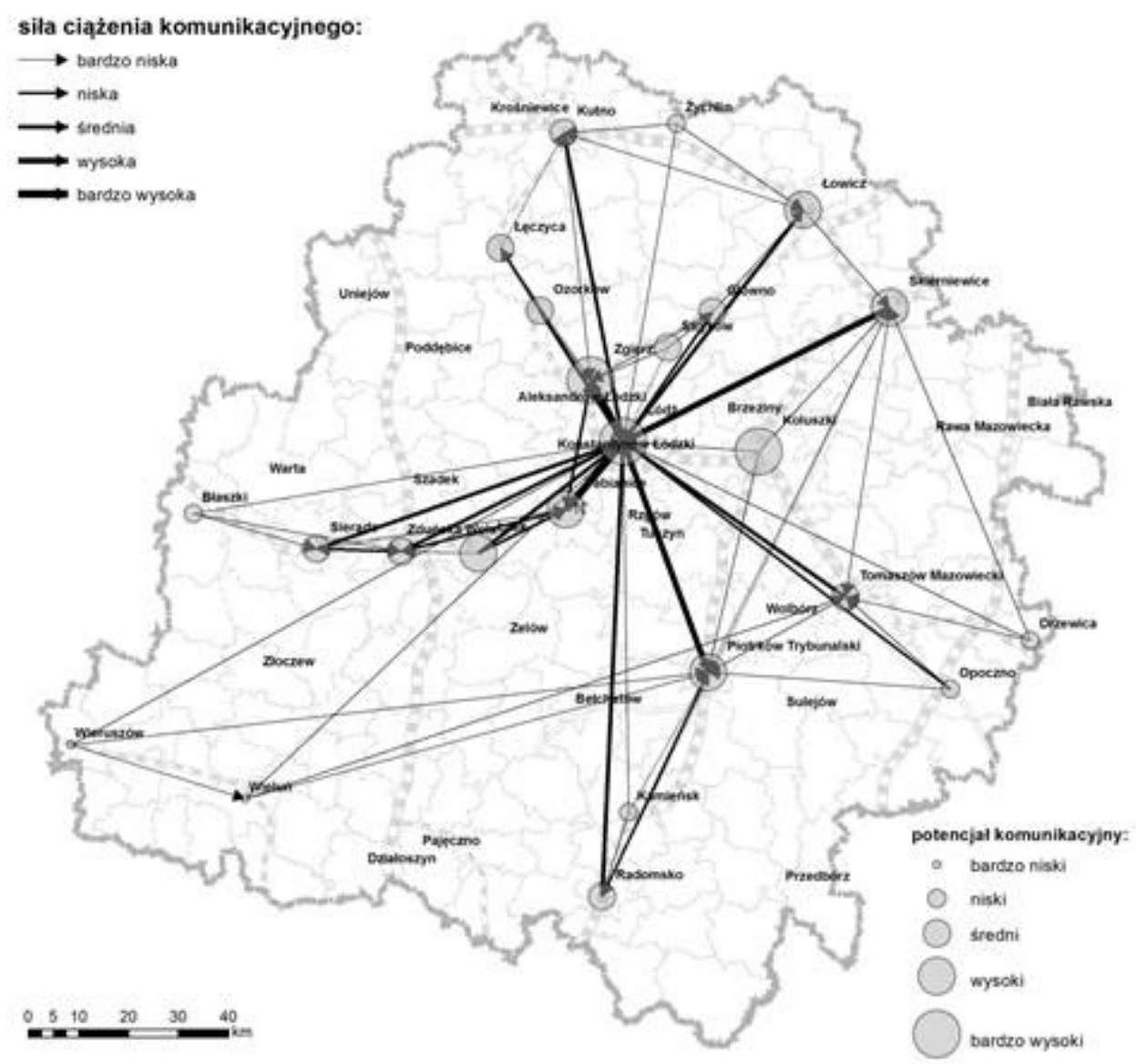

Rycina 3.10. Potencjał oraz siła i kierunek ciążenia komunikacyjnego (I, II i III rzędu) miast województwa łódzkiego w świetle komunikacji kolejowej (opór przestrzeni w jednostkach czasu)

Źródło: opracowanie własne

Wzrosły zaś wyraźnie w przypadku miast, do których prowadzą linie kolejowe o najwyższych parametrach technicznych, jak Łowicz, Skierniewice czy Kutno. Niezmienne pozostały pary miast połączone najsilniejszymi relacjami wzajemnymi. Zmieniła się jednak siła poszczególnych połączeń. Dla przykładu relacja Łódź-Pabianice osłabła o 30\%, a Łódź-Piotrków znacząco się wzmocniła (o 20\%). Wśród połączeń najwyższych rzędów najwyraźniej zaznacza się pojawienie połączeń skierowanych do Skierniewic, m.in. z Tomaszowa Mazowieckiego czy Piotrkowa Trybunalskiego. Straciły natomiast na znaczeniu połączenia do Pabianic, szczególnie z miast wschodniej części województwa.

Wprowadzenie do analizy czynnika kosztu podróży powoduje, że jej wyniki wyraźnie nawiązują do wielkości potencjałów i sił ciążenia komunikacyjnego 
przy założeniu jednostek długości. Wynika to oczywiście z bezpośredniej korelacji pomiędzy ceną biletu za przejazd a jego długością. Na uwagę zasługuje znaczny wzrost potencjału Zduńskiej Woli, który przy założeniu analizy cen uplasował miasto na trzeciej pozycji (rycina 3.11).

W przypadku połączeń tramwajowych, niezależnie czy do analizy zostanie włączona odległość, czas czy cena, zdecydowanie największe potencjały komunikacyjne posiadają Łódź i Zgierz. Również między tymi ośrodkami występuje najsilniejsza relacja. Jedynie w przypadku analiz cenowych znaczną przewagę nad Ozorkowem i Konstantynowem Łódzkim zyskują Pabianice. Wynika to z wysokiej liczby ludności Pabianic i zniwelowanej różnicy odległości poprzez jednako-

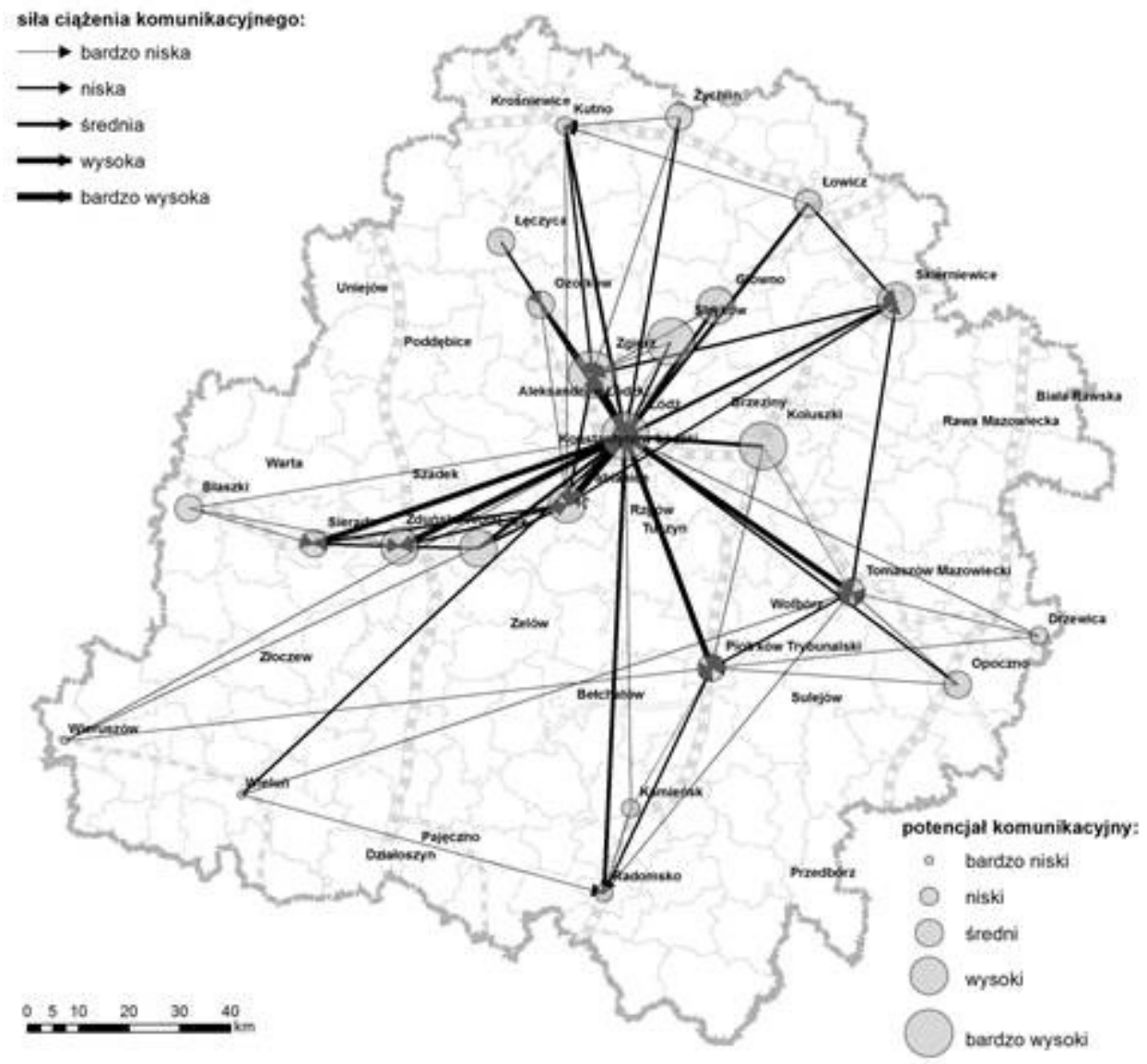

Rycina 3.11. Potencjał oraz siła i kierunek ciążenia komunikacyjnego (I, II i III rzędu) miast województwa łódzkiego w świetle komunikacji kolejowej (opór przestrzeni w jednostkach pieniężnych)

Źródło: opracowanie własne 
wą cenę biletu aglomeracyjnego. Również w każdym przypadku Konstantynów Łódzki jest miastem o potencjale najniższym.

\subsection{Funkcjonowanie transportu zbiorowego a poziom dostępności}

Regionalna komunikacja zbiorowa w województwie łódzkim przyczynia się do rozwoju zupełnie nowych możliwości kształtowania powiązań w układach osadniczych. Dotychczas odrębnie rozwijające się jednostki mogą być łączone we wspólny organizm. Zwiększa się siła wzajemnych powiązań całego układu osadniczego, maleje znaczenie odległość pomiędzy poszczególnymi ośrodkami na rzecz czasu przejazdu. Charakterystyczny dla struktur osadniczych opartych na regionalnej komunikacji zbiorowej jest rozczłonkowany kształt geometryczny niezachowujący ciągłości zainwestowania. Efektywnie działający system połączeń komunikacji zbiorowej przyczynia się do dekoncentracji funkcji (Pięciński 1977).

Województwo łódzkie posiada dogodne powiązania komunikacją autobusową zarówno w ujęciu wewnątrzregionalnym, jak i krajowym oraz międzynarodowym. Regularne połączenia kolejowe w obrębie województwa mają zdecydowanie mniejszy zasięg terytorialny niż autobusowa komunikacja pasażerska. Część miast regionu posiada komunikację miejską, której poziom jest zadowalający zarówno pod względem liczby obsługiwanych pasażerów, jak i długości linii komunikacyjnych. Usprawnienia wymaga natomiast skomunikowanie z Łodzią ośrodków miejskich w ramach aglomeracji łódzkiej, czemu towarzyszyć powinna poprawa stanu infrastruktury i taboru (Strategia rozwoju województwa łódzkiego 2020). Sieć tramwajowa ze względu na swój lokalny charakter ma nieznaczny wpływ na spójność sieci transportowej regionu, jednakże nawet funkcjonujące aktualnie przewozy tramwajowe wydają się w pełni nie wykorzystywać istniejących możliwości.

Analizę wpływu funkcjonowania transportu zbiorowego na poziom dostępności transportowej dokonano w pierwszej kolejności na podstawie porównania częstotliwości, czasu oraz kosztu podróży pomiędzy parami miast, przy założeniu podróży każdym z trzech badanych środków transportu. Do analizy włączono wyłącznie połączenia bezpośrednie, aby zapewnić porównywalność wyników. Druga część analizy (przedstawiona w dalszej części rozdziału) jest przeprowadzona na wyższym poziomie szczegółowości. Z relacji miasto-miasto badanie zostało przeniesione na poziom połączeń pomiędzy poszczególnymi przystankami na trasach transportu zbiorowego między miastami w zakresie izochrony jednogodzinnego dojazdu do każdego z miast. Wokół przystanków wyznaczono bufory, których granicę stanowią ekwidystanty $1 \mathrm{~km}$ od miejsca zatrzymania. W Polsce zwyczajowo przyjmuje się, że strefa oddziaływania przystanków transportu pub- 
licznego obejmuje obszar o promieniu od $500 \mathrm{~m}$ do $1 \mathrm{~km}$. Oznacza to, że mieszkańcy mogą dotrzeć do przystanku, idąc pieszo w czasie od 6 do 12 minut przy założeniu, że średnia prędkość ich przemieszczania wynosi $5 \mathrm{~km} / \mathrm{h}$ (Majewski, Beim 2008). Oczywiście, taki model nie odzwierciedla możliwości generowania przez przystanek popytu na usługi transportu zbiorowego, nawet jeśli byłby realizowany we wszystkich możliwych kierunkach i przy maksymalnej częstotliwości. Wynika to z faktu, iż każdy z mieszkańców może mieć inną odległość graniczną, wraz z którą rezygnuje ze skorzystania z przystanku. Dodatkowo, dla hipotetycznego użytkownika komunikacji zbiorowej liczą się obok odległości także możliwe udogodnienia, ułatwiające dotarcie na przystanek bądź bariery utrudniające jego osiągnięcie. Siła oddziaływania tych czynników jest inna dla każdego mieszkańca i silnie zdeterminowana cechami indywidualnymi każdego z użytkowników, takimi jak ich wiek, stan zdrowia, płeć, miejsce zamieszkania itp. (Gadziński 2010). Zasadniczo w literaturze napotyka się metodologiczne problemy związane z odległością graniczną dla różnych typów transportu. W Wielkiej Brytanii za maksymalny dystans dojścia do przystanku autobusowego w mieście przyjmuje się ekwidystantę $640 \mathrm{~m}$, zaś do kolei regionalnej bądź metra $960 \mathrm{~m}$ (Majewski, Beim 2008). Niemieccy urbaniści uznają za maksymalną drogę dojścia do przystanku autobusowego odległość $300 \mathrm{~m}$, tramwajowego $400 \mathrm{~m}$, zaś do kolei regionalnych 500 m (Loose 2001). Różnice w wyznaczaniu odległości granicznych względem środka transportu wynikają z kilku zasadniczych kwestii. Większe odległości od przystanku tramwajowego względem autobusowego zmniejszają nakłady inwestycyjne poniesione na budowę nowych linii tramwajowych przy jednoczesnym założeniu, że mieszkańcy są w stanie dalej dojść do przystanku, jeżeli będą mogli szybciej i bardziej komfortowo dotrzeć do celu.

Analizę porównawczą środków transportu rozpoczęto od czynnika częstotliwości połączeń. Każda z relacji, która łączy w sposób bezpośredni miasta województwa łódzkiego, realizowana jest $\mathrm{z}$ najwyższą częstotliwością przez przewoźników autobusowych i busowych. Najwyższa dysproporcja w stosunku do połączeń kolejowych występuje w relacji Łódź-Pabianice, a przewaga częstotliwości komunikacji samochodowej przekracza 180 połączeń na dobę. Podobna przewaga występuje w przypadku relacji Zgierz-Ozorków. Ogólnie podkreślić należy, że w obszarze Łódzkiego Obszaru Metropolitalnego: Łódź-Aleksandrów Łódzki, Łódź-Tuszyn oraz Rzgów-Tuszyn, występuje monopol komunikacji samochodowej. Częstotliwość połączeń tramwajowych wyraźnie przewyższa liczbę kursów kolejowych - w przypadku relacji Łódź-Zgierz różnica w częstotliwości osiąga 90 połączeń w ciągu doby. W przypadku relacji Łódź-Pabianice dysproporcja nie przekracza 29 połączeń. Taka sytuacja wynika z różnego charakteru aktualnie funkcjonujących przewozów kolejowych i komunikacji tramwajowej. Zmianę sytuacji może spowodować uruchomienie kolei aglomeracyjnej, która w założeniach swojego funkcjonowania ma wysoką częstotliwość obsługi linii oraz dużą liczbę miejsc zatrzymania. Niemniej jednak połączenia tramwajowe nie 
stanowią konkurencyjnej oferty w stosunku do połączeń autobusowych i busowych. Potrzeba zapewnienia częstotliwości kursowania środków transportowych, jako czynnika dostosowania usług transportowych do potrzeb podróżnego, nie zawsze jest należycie doceniana i realizowana, co często wynika z niedostatków technicznych (głównie taborowych), ale również z baraku właściwej organizacji przewozów. Częstotliwość może w określonym stopniu zrekompensować tak istotny walor motoryzacji indywidualnej, jakim jest możliwość rozpoczęcia podróży w krótkim czasie po podjęciu decyzji.

Problematykę czasu w transporcie należy rozpatrywać nie tylko z punktu widzenia zainteresowania podróżnych, ale również samych przedsiębiorstw przewozowych w związku z planowaniem i organizowaniem eksploatacji, mierników pracy przewozowej czy kosztów tej pracy (Kolarski 1976). Znaczenie czasu, jako jednego z fundamentalnych czynników determinujących działalność transportową, wzrasta wraz z postępem cywilizacyjnym. $Z$ upływem lat zyskuje na wartości czas, rośnie jego społeczna i gospodarcza użyteczność. Ocena znaczenia i wartości czasu przeznaczanego na podróże jest zadaniem niełatwym i wielowymiarowym. Brakuje jednolitego, bezwzględnie obiektywnego kryterium wartości czasu w transporcie pasażerskim. Ocena może być jedynie zindywidualizowana w stosunku od celu i charakteru przejazdu.

W ogólnym ujęciu znaczenie i wartość czasu w przewozie osób można badać pod kątem widzenia interesów: ogólnospołecznych czy też ogólnogospodarczych, indywidualnych podróżnego oraz przedsiębiorstwa transportowego. Transport pasażerski pełni ważną rolę w każdej niemalże dyscyplinie działalności człowieka, związanej z bezpośrednimi kontaktami osobistymi. Toteż efektywność funkcjonowania transportu, oceniana m.in. przez kryterium czasu, oddziałuje na sferę gospodarczą, socjalną, kulturalną, oświatową czy polityczną. Od tej sprawności uzależniona jest szybkość i częstotliwość potrzebnych kontaktów. Zmniejszanie przestrzeni czasowej w promieniu dojazdów do ośrodków administracyjnych, naukowych, gospodarczych, kulturalnych itp. powoduje aktywizację poszczególnych dziedzin życia.

Czas przeznaczony przez podróżnego na przejazd jest praktycznie bezproduktywnie dla niego straconym. Wszelka oszczędność czasu może skutkować korzyściami w postaci odpowiedniego zmniejszenia zmęczenia podróżą, ograniczenia kosztów podróży, lepszego wykorzystania pozostałej części funduszu czasu na wypoczynek, sprawy osobiste itd. Ogólnie można przyjąć, że każdy pasażer jest zainteresowany skracaniem czasu podróży, wprawdzie zakres i stopień tego zainteresowania - w zależności od możliwych do osiągnięcia korzyści - jest stosownie spersonalizowany. Ze strony przedsiębiorstw transportowych ważna staje się szybkość przewozu. Wzrost szybkości pociąga za sobą zwiększenie obrotu środków transportowych, lepsze wykorzystanie infrastruktury, zwiększenie wydajności pracy i zazwyczaj zmniejszenie kosztów własnych transportu. Czasem 
może jednakże skutkować zwiększonymi nakładami na budowę lepszych dróg czy też użyciem trwalszych i mocniejszych środków transportowych (ibid.).

Analiza bezpośrednich połączeń pomiędzy miastami województwa łódzkiego pod względem ich czasu wskazuje na najwyższą efektywność przewoźników autobusowych i busowych. W przypadku Radomska występuje najwyższa konkurencja ze strony przewozów kolejowych. Można do niego dotrzeć pociągiem najszybciej z 9 innych ośrodków. W przypadku Kutna oraz Łowicza 8 połączeń kolejowych pozawala na najszybszą podróż. Do Łodzi prowadzi jedynie 7 połączeń kolejowych, teoretycznie pozwalając na najszybszą podróż (ze Skierniewic, Radomska, Zduńskiej Woli, Sieradza, Koluszek, Drzewicy oraz Błaszek). W przypadku podróży do Kamieńska, teoretyczne czasy przejazdu autobusem i pociągiem są sobie równe. Komunikacja tramwajowa jest konkurencyjna pod względem czasu wyłącznie w relacji Łódź-Pabianice i Łódź-Zgierz, gdzie osiąga taki sam czas jak połączenia autobusowe. Siedem bezpośrednich najszybszych połączeń kolejowych (w stosunku do 11 autobusowych) prowadzi również do Tomaszowa Mazowieckiego oraz Zgierza. Inne ośrodki, do których prowadzą teoretycznie najszybsze połączenia kolejowe, to Skierniewice i Sieradz (po 5 połączeń), Pabianice, Piotrków i Zduńska Wola (po 4 połączenia), Łask i Ozorków (po 2 połączenia) oraz Wielun i Opoczno (po 1 połączeniu). Nie zawsze jednak tylko szybkość środków transportowych decyduje o całkowitym czasie podróży. Często czas ten uzależniony jest od bezpośredniości połączeń oraz dostępności i częstotliwości kursowania środków transportowych.

Zaspokajanie masowego popytu na usługi przewozowe wiedzie niekiedy do zbytniego zagęszczenia środków transportowych w stosunku do możliwości przelotowych dróg transportowych. W wyniku czego zwiększenie liczby miejsc zatrzymania oraz częstotliwości kursowania środków transportowych skutkuje obniżeniem ich szybkości eksploatacji, zwiększając koszty (ibid.).

Ostatnim elementem, który poddano porównaniu, jest cena biletu umożliwiającego bezpośredni przejazd pomiędzy miastami województwa łódzkiego każdym z analizowanych środków transportu. Konkurencyjność przewozów autobusowych i busowych jest jeszcze wyższa niż w przypadku kryterium czasu. Jedynie 26 połączeń realizowanych przez przewoźników kolejowych ma cenę niższą niż wykonywane na tej samej trasie połączenia samochodowe. Największa liczba konkurencyjnych pod względem ceny połączeń kolejowych prowadzi do Zgierza i Koluszek (po 6 połączeń). W przypadku Tomaszowa Mazowieckiego oraz Radomska i Łowicza po 5 połączeń. Do Skierniewic i Kutna prowadzą po 4 bezpośrednie połączenia kolejowe o cenach biletów niższych od tych wyznaczonych przez przewoźników samochodowych. W przypadku Łodzi, Piotrkowa Trybunalskiego, Pabianic, Zduńskiej Woli, Sieradza, Ozorkowa, Łęczycy, Żychlina, Drzewicy, Strykowa i Kamieńska są to nie więcej niż 3 połączenia na dobę. Komunikacja tramwajowa stanowi cenową alternatywę jedynie w relacji Łódź- 
Zgierz, gdzie przejazd tramwajem kosztuje dokładnie tyle samo, ile komunikacja autobusowa.

Dostępność w ujęciu transportu zbiorowego uwarunkowana jest nie tylko częstotliwością połączeń, długością ich trwania czy kosztem, ale również czasem potrzebnym na nabycie biletu czy zajęcie dogodnego miejsca w środku transportu. Wskazać należy również odległość „domu” podróżnego od punktów zatrzymywania się środków transportowych, liczby tych punktów i ich rozmieszczeniem. Dlatego też badanie poszerzono o analizę połączeń pomiędzy każdym z 44 miast województwa łódzkiego a przystankami znajdującymi się w ich izochronie jednogodzinnej. Drugim założeniem wstępnym był wybór przystanków zlokalizo-

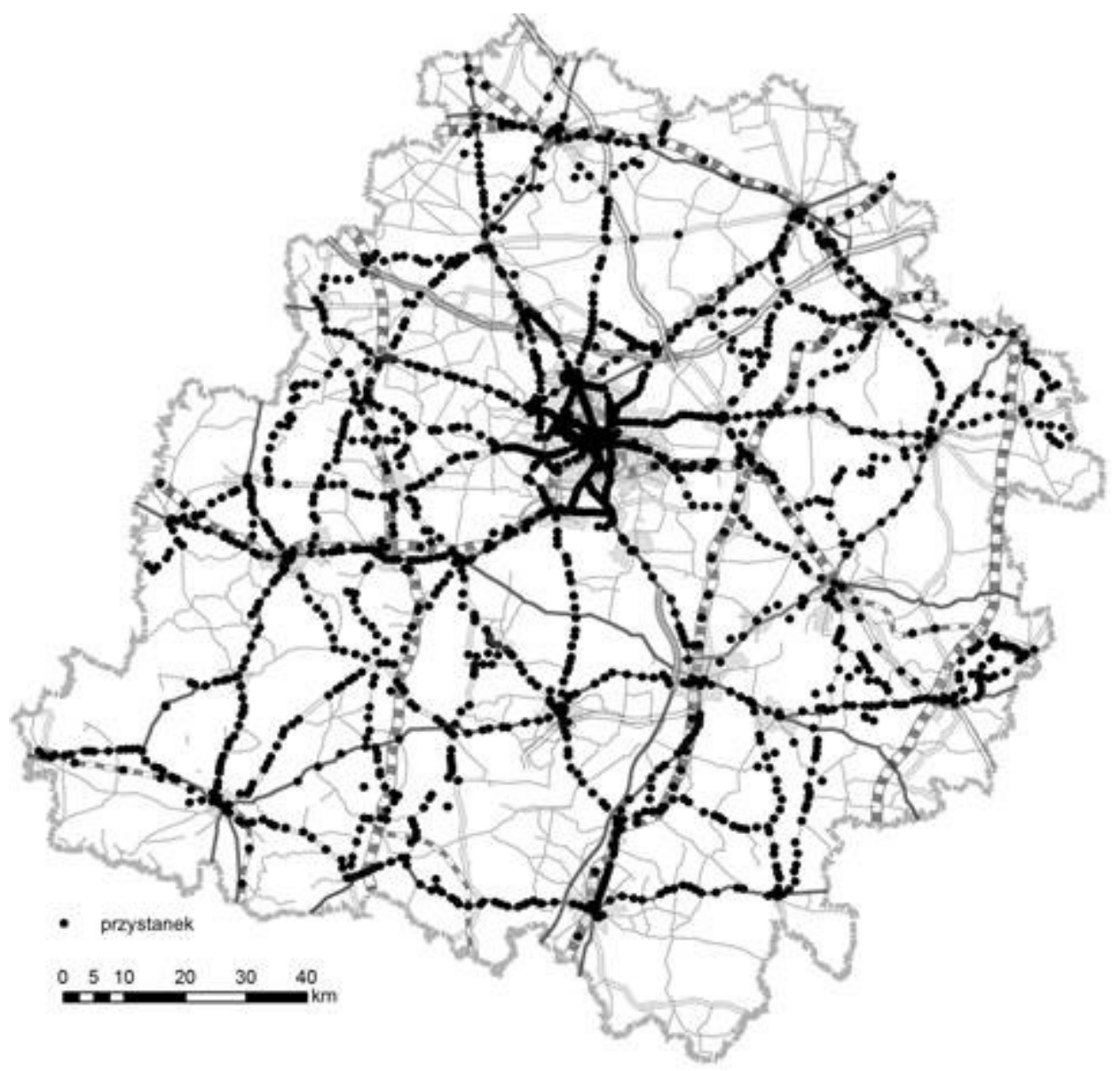

Rycina 3.12. Położenie przystanków poddanych analizie Źródło: opracowanie własne 
wanych na trasach prowadzących z danego miasta to wszystkich pozostałych 43 ośrodków. W przypadku gdy trasa prowadząca do danego miasta jest kontynuowana poza jego granicę, przystanki włączano do momentu osiągnięcia 60 minut dojazdu.

Za przystanek początkowy przyjmowano ostatnie na danej trasie miejsce zatrzymania zlokalizowane $\mathrm{w}$ granicach administracyjnych analizowanego miasta. W badaniu uwzględniono przystanki obsługiwane przez spółki PKS, prywatnych przewoźników typu BUS, lokalny transport zbiorowy (w tym komunikację tramwajową realizowaną przez Miejskie Przedsiębiorstwo Komunikacyjne w Łodzi) oraz przewoźników PKP. Na obszarze województwa łódzkiego badaniu poddano łącznie 4506 przystanków (rycina 3.12).

Dla każdego z przystanków określono, poza rodzajem przewoźnika, który go obsługuje, również częstotliwość kursowania, czas i koszt dojazdu do miasta. Za dane wejściowe do badania posłużyły opisy tras i informacje $\mathrm{z}$ tabliczek przystankowych pozyskane od przedstawionych wcześniej źródeł. Geolokalizację przystanków przeprowadzono w oparciu o ich dane adresowe oraz mapy topograficzne województwa łódzkiego, plany miast, zdjęcia satelitarne oraz wykonaną wcześniej geolokalizację - jak w przypadku przystanków obsługiwanych przez MPK Łódź (po uprzedniej weryfikacji).

Analizując całą zbiorowość przystanków poddanych badaniu pod kątem przewoźników je obsługujących, należy podkreślić wyraźną dominację spółek PKS. Docierają łącznie do 3199 przystanków w wyznaczonych izochronach, realizując połączenia do każdego z 44 miast województwa łódzkiego. W większości przypadków (poza Zgierzem, Aleksandrowem Łódzkim, Rawą Mazowiecką, Strykowem i Rzgowem) przewoźnicy PKS obsługują również największą liczbę przystanków w zakresie jednej godziny dojazdu do miasta (rycina 3.13).

Największa ich liczba występuje w okolicach Łodzi (229), natomiast największa dysproporcja pomiędzy przewoźnikami występuje w przypadku Sieradza, gdzie na 139 przystanków obsługiwanych przez PKS przypada zaledwie 18 obsługiwanych przez lokalny transport zbiorowy i 14 przez przewoźników PKP. Są też miasta, takie jak Pajęczno, Działoszyn, Złoczew, Warta, Biała Rawska i Szadek, gdzie przystanki na trasach do miast województwa łódzkiego obsługują wyłącznie spółki PKS. Drugim pod względem ilości obsługiwanych przystanków rodzajem przewoźników są operatorzy busów. Łącznie obsługują 1220 przystanków. Największa ich liczba znajduje się przy trasach prowadzących do Łodzi. Natomiast podstawę transportu zbiorowego stanowią one w przypadku Aleksandrowa Łódzkiego i Strykowa, gdzie wyraźnie przewyższają liczebnością każdy inny rodzaj przewoźników. Lokalny transport zbiorowy w wyznaczonych izochronach na terenie województwa łódzkiego obsługuje jedynie 731 przystanków. Przewoźnicy tego typu stanowią podstawę transportu zbiorowego w przypadku Zgierza oraz Rzgowa, dominując w strukturze nad pozostałymi operatorami. Najwięcej przystanków obsługują lokalni przewoźnicy na trasach prowadzących do Łodzi (140), natomiast 


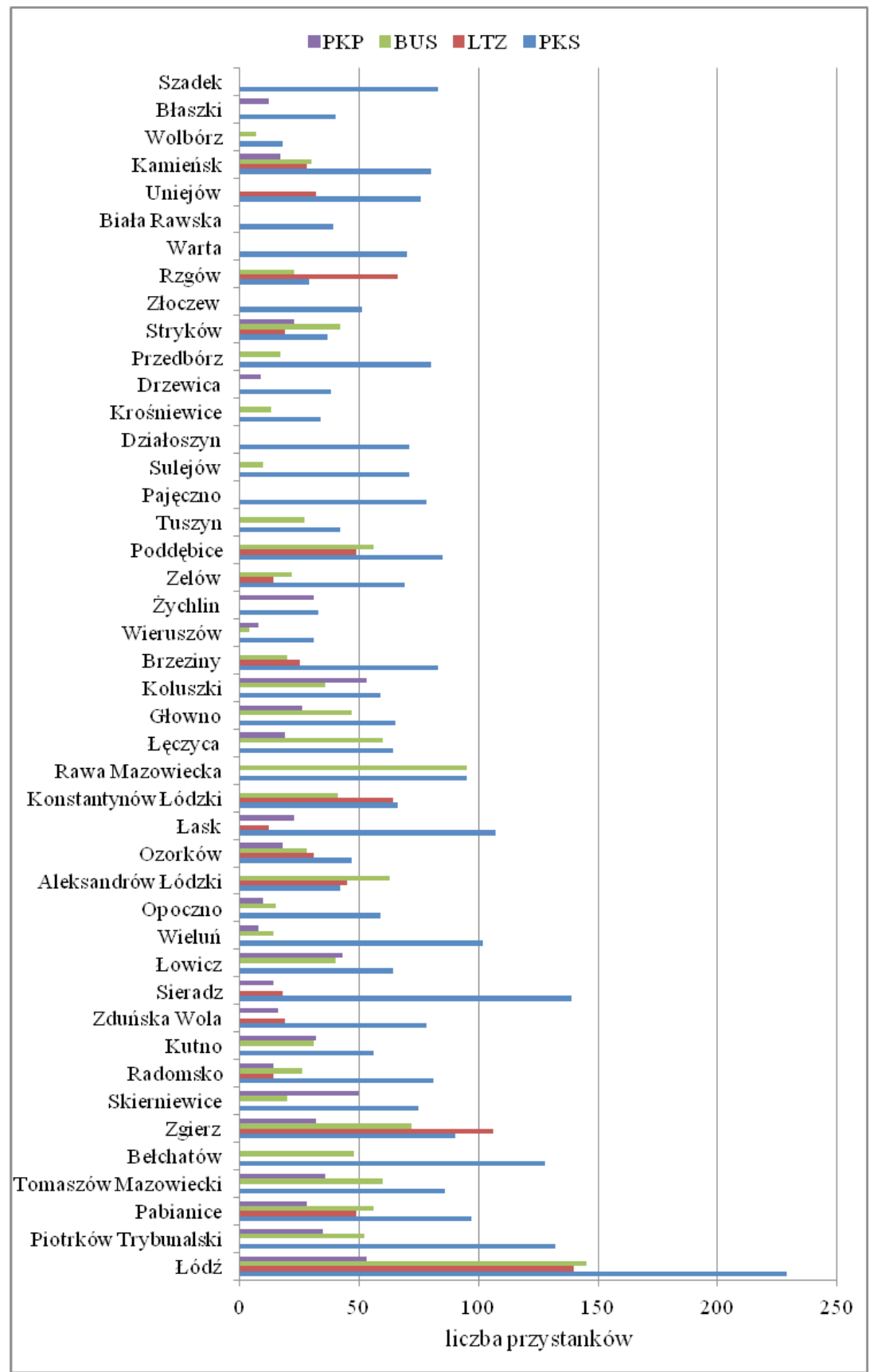

Rycina 3.13. Liczba przystanków PKS, LTZ, BUS oraz PKP w izochronie jednogodzinnej wokół miast województwa łódzkiego

Źródło: opracowanie własne 
najmniej - przewoźnicy realizujący połączenia kolejowe. Łącząc 24 miasta województwa łódzkiego, obsługują w ich izochronach jednogodzinnych 610 przystanków. Wynika to z charakteru połączeń kolejowych oraz zasad lokalizowania przystanków, które często niedopasowane są do aktualnych potrzeb oraz specyfiki wykorzystywanego taboru. Największą liczbą przystanków kolejowych, z których możliwe jest dotarcie do miasta w ciągu godziny, charakteryzują się Łódź oraz Koluszki. Komunikacja kolejowa stanowi ważny element w strukturze przewozów pasażerskich (pod względem liczby przystanków) również w przypadku Żychlina, Łowicza i Skierniewic, gdzie przystanki kolejowe stanowią ponad 40\% wszystkich miejsc zatrzymania środków transportu zbiorowego.

Lódź jest miastem o największej liczbie przystanków umożliwiających dotarcie do niej w ciągu jednej godziny. Łącznie jest ich 410, z czego największą grupę stanowią przystanki obsługiwane przez spółki PKS (56\%). Lokalny transport zbiorowy oraz przewoźnicy typu BUS obsługują niemalże taką samą liczę przystanków (około 140). Najmniej liczną grupę (53) stanowią przystanki kolejowe. Niemniej jednak kolej pozwala dotrzeć do Łodzi z najbardziej oddalonego od niej przystanku - Skierniewice Rawka - będącego zgodnie z danymi przewoźnika oddalonym o $71 \mathrm{~km}$. W przypadku połączeń autobusowych najdalszy przystanek to Kutno - Troczewskiego, oddalony jednak tylko o $54 \mathrm{~km}$. Trasy, po których realizowany jest transport zbiorowy do Łodzi, rozchodzą się promieniście we wszystkich kierunkach. Łódź, jako miasto centralne regionu, największy rynek pracy, siedziba instytucji administracyjnych i wielu placówek usługowych o znacznym zasięgu regionalnym (szkolnictwo, opieka zdrowotna, handel, kultura i rozrywka), wymaga odpowiednio rozwiniętego systemu transportu zbiorowego, umożliwiającego dojazd z całego obszaru województwa. Liczba połączeń może być zróżnicowana, tak jak zróżnicowane jest znaczenie Łodzi (dla obszarów bezpośrednio sąsiadujących z miastem wojewódzkim jest dużo większe, niż dla obszarów położonych w dalszej odległości). Częstotliwość połączeń zmienia się od kilku na dobę, jak w przypadku Szadku, do ponad 200 np. dla Ozorkowa. Niezależnie od tego, dostępność połączeń powinna być zapewniona przynajmniej w minimalnym zakresie dla wszystkich mieszkańców regionu. Czas dojazdu do miasta również sukcesywnie zmniejsza się wraz ze zmniejszającą się odległością. Jedynie w przypadku połączenia tramwajowego Łódź-Ozorków oraz przystanków kolejowych przed Koluszkami czasy dojazdów są wyraźnie wyższe (rycina 3.14).

Do Piotrkowa Trybunalskiego $\mathrm{w}$ ciągu jednej godziny możliwe jest dotarcie ze 167 przystanków. Ponad 79\% jest obsługiwanych przez spółki PKS. Przewoźnicy prywatni obsługują zaledwie 31\% przystanków. Miejsc zatrzymania kolei jest jedynie 35, natomiast podróżując godzinę pociągiem, możliwe jest dotarcie do Piotrkowa Trybunalskiego z oddalonych o 95 km Lipców Reymontowskich. W przypadku Piotrkowa Trybunalskiego trasy komunikacyjne również rozchodzą się promieniście, w siedmiu głównych kierunkach (rycina 3.15). Przy czym uwidacznia się nieznaczne rozszerzenie izochrony jednogodzinnej na osi północ-po- 


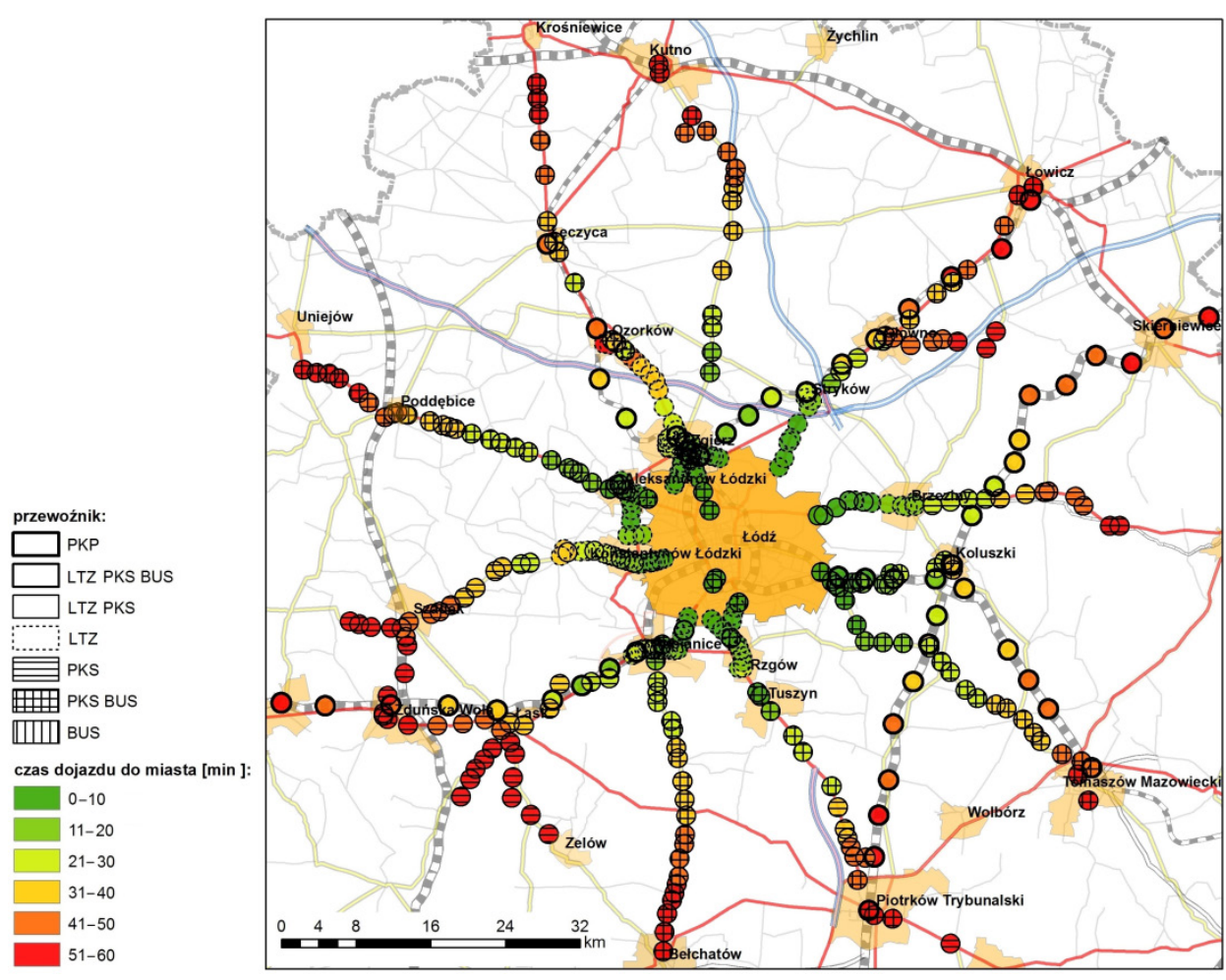

Rycina 3.14. Rodzaj przewoźnika oraz czas dojazdu do Łodzi w zakresie izochrony jednogodzinnej Źródło: opracowanie własne

łudnie w związku z przebiegiem linii kolejowej. Najwyższą częstotliwością kursów charakteryzują się połączenia z Sulejowa, Bełchatowa i Łodzi, wykonywane nawet powyżej 200 razy na dobę.

W ciągu jednej godziny do Pabianic możliwe jest dotarcie ze 166 przystanków. 58\% z nich obsługiwanych jest przez PKS. Przewoźnik ten zapewnia połączenie z najbardziej oddalonym przystankiem - Lubiec $(49 \mathrm{~km})$. Lokalny transport zbiorowy oraz przewoźnicy bus obsługują po około 50 przystanków. Podobnie jak w przypadku Łodzi oraz Piotrkowa Trybunalskiego, najmniej liczne są przystanki kolejowe (28). Zdecydowanie największe zagęszczenie miejsc zatrzymania występuje na trasie do Łodzi i Rzgowa. Pozostałe kierunki wyposażone w największą liczbę przystanków dotyczą Sieradza, Zelowa i Bełchatowa. Wyraźną barierą czasową w realizacji połączeń z północy i północnego wschodu województwa do Pabianic jest Łódź. Większość z nich przebiega przez Łódź, jako główny ośrodek regionu, a w związku z utrudnieniami, jakie występują w ruchu na terenie miasta, czas przejazdu wyraźnie wzrasta. Najwyższą częstotliwością charakteryzują się 


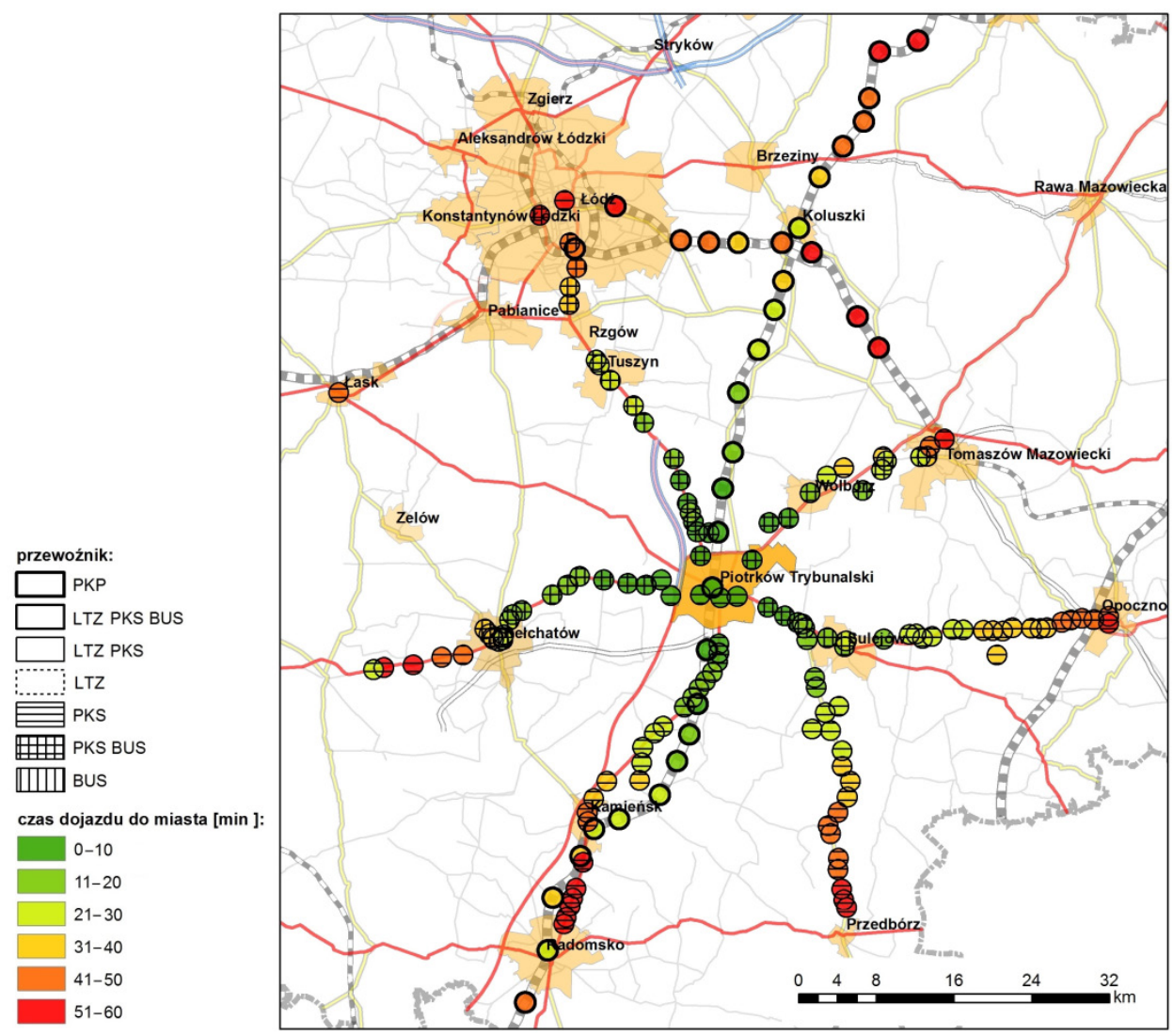

Rycina 3.15. Rodzaj przewoźnika oraz czas dojazdu do Piotrkowa Trybunalskiego w zakresie izochrony jednogodzinnej

Źródło: opracowanie własne

połączenia na trasach Pabianice-Łask oraz Pabianice-Łódź, osiągając nawet powyżej 150 połączeń na dobę.

Obszar wokół Tomaszowa Mazowieckiego w zakresie izochrony jednogodzinnej wyposażony jest w 146 przystanków, z których niemal 65\% obsługiwanych jest przez PKS, $45 \%$ przez prywatnych przewoźników, a $27 \%$ to przystanki kolejowe. W ciągu 60 minut do Tomaszowa Mazowieckiego możliwe jest dotarcie z Bełchatowa, Piotrkowa Trybunalskiego, Wolborza, Sulejowa, Opoczna, Drzewicy, Łodzi, Koluszek, Rawy Mazowieckiej oraz Skierniewic, będących jednocześnie najbardziej oddalonym przystankiem $(66 \mathrm{~km})$, z którego dojazd możliwy jest dzięki połączeniom kolejowym. Częstotliwości poszczególnych połączeń nie przekraczają 60 na dobę, a najwyższe wartości dotyczą kursów autobusowych do Lodzi oraz Wolborza, Piotrkowa Trybunalskiego i Rawy Mazowieckiej. Wy- 
raźnie najdroższym środkiem transportu jest kolej, natomiast cena dojazdu do najbardziej oddalonych Skierniewic nie przekracza $20 \mathrm{zł}$.

W przypadku Bełchatowa występuje wyraźna dominacja przystanków obsługiwanych przez przewoźników PKS. Obsługują oni wszystkie 128 przystanków. Jedynie $46 \mathrm{z}$ nich dodatkowo obsługują busy. W ciągu godziny do Bełchatowa możliwe jest dotarcie z Łodzi, Pabianic, Wolborza, Piotrkowa Trybunalskiego, Sulejowa, Kamieńska, Radomska, Wielunia, Zelowa oraz Łasku. Największe zagęszczenie przystanków występuje pomiędzy Bełchatowem a Zelowem, zaś największą częstotliwością charakteryzuje się połączenie z Piotrkowa Trybunalskiego, wykonywane dziennie ponad 50-krotnie. Jedynie przejazd z Wolborza kosztuje więcej niż 15 zł. Dojazd z każdego innego przystanku nie przekracza tej kwoty.

Jak już wspomniano, Zgierz jest jednym z dwóch ośrodków w województwie łódzkim, w których przeważają przystanki obsługiwane przez transport lokalny. Spośród 217 wszystkich przystanków obsługuje on niemalże połowę. Przewoźnicy PKS docierają tylko do $40 \%$ przystanków. Busy obsługują zaledwie 72 przystanki, a przewoźnicy kolejowi 32. Zdecydowanie największe zagęszczenie przystanków występuje na trasach prowadzących do Łodzi oraz dalej w kierunku południowym. Podobnie wysoką gęstością miejsc zatrzymania charakteryzuje się połączenie z Ozorkowem oraz droga wojewódzka nr 702 w kierunku Żychlina. Sieć przystanków prowadzi również do Krośniewic przez Łęczycę, Kutna, Łowicza przez Głowno i Stryków oraz do Łasku. Uwidacznia się wskazana wcześniej bariera w postaci Łodzi. Jedynie połączenia kolejowe, niezależne od płynności ruchu drogowego i ograniczonej liczby przystanków, ,przechodzą" przez Łódź w kierunku Zduńskiej Woli i Koluszek w granicy 60 minut. Największa częstotliwość połączeń dotyczy przystanków zlokalizowanych na trasie do Ozorkowa i Łodzi oraz w obrębie tych miast. Osiąga ona poziom nawet 200 połączeń na dobę.

W przypadku Skierniewic, w zakresie izochrony jednogodzinnej zinwentaryzowano 125 przystanków na trasach prowadzących do innych miast województwa. Do $60 \%$ z nich docierają autobusy PKS. Jedynie na trasie do Łowicza komunikacja odbywa się również za pośrednictwem busów. Bardzo dużą rolę w obsłudze ruchu pasażerskiego do Skierniewic odgrywają połączenia kolejowe (50 przystanków). Dostępność do obszaru województwa na północ od Żychlina i południe od Brzezin i Rawy Mazowieckiej zapewniają jedynie połączenia kolejowe. Gęstość przystanków transportu zbiorowego zwiększa się wprost proporcjonalnie do zmniejszania się odległości do Skierniewic. Największa częstotliwość połączeń dotyczy relacji Skierniewice-Łowicz oraz Skierniewice-Rawa Mazowiecka.

W zakresie 60 minut dojazdu do Radomska zlokalizowanych jest 100 przystanków. Zdecydowanie największą ich liczbę obsługuje PKS (81). Prywatni przewoźnicy oferują podróż do Radomska z 26 przystanków, natomiast LTZ i PKP jedynie z 14. Sieć połączeń transportu zbiorowego, a co za tym idzie, liczba przystanków jest determinowana położeniem miasta przy południowej granicy 
województwa. Podobna sytuacja ma miejsce w przypadku wszystkich miast województwa zlokalizowanych przy jego granicy. Trasy prowadzące do Radomska mają układ równoleżnikowy (Działoszyn-Pajęczno-Radomsko-Przedbórz) oraz południkowy (Radomsko-Kamieńsk-Bełchatów/Piotrków Trybunalski). Częstotliwość połączeń w zakresie izochrony jednogodzinnej dojazdu do Radomska jest nieduża, nie przekracza bowiem 40 połączeń w ciągu doby.

Dostępność transportowa Kutna w dużej mierze zdeterminowana jest jego peryferyjnym położeniem w sieci osadniczej. W zakresie jednej godziny dojazdu do Radomska zlokalizowanych jest 88 przystanków. Dominującym przewoźnikiem jest PKS. Wykorzystanie przewozów kolejowych pozwala dotrzeć do Kutna z najdalej względem niego zlokalizowanego przystanku - Leonów $(80 \mathrm{~km})$. Kolej jest też wyraźnie najdroższą formą transportu. Uzupełnieniem oferty przewozowej są usługi świadczone przez prywatnych przewoźników bus, realizujących połączenia z Łęczycy oraz Zgierza i Łodzi. Z dwóch ostatnich ośrodków połączenia do Radomska charakteryzują się największą częstotliwością.

W przypadku Zduńskiej Woli badaniu poddano 107 przystanków. Największe ich zagęszczenie występuje pomiędzy Zduńską Wolą a Sieradzem. Dominującym kierunkiem realizacji transportu zbiorowego jest układ równoleżnikowy: granica województwa - Błaszki-Sieradz-Zduńska Wola-Szadek/Łask-Łódź. Uzupełnieniem jest grupa przystanków na trasie w kierunku Bełchatowa. Najbardziej oddalonym od Zduńskiej Woli przystankiem jest obsługiwana przez kolej Łódź Kaliska. Częstotliwość połączeń w zakresie jednej godziny nie przekracza 20 relacji w ciągu doby, zaś koszt dojazdu nie przekracza 15 zł.

Obszar wyznaczony przez jednogodzinną izochronę dojazdu transportem zbiorowym do Sieradza zawiera 163 przystanki. Ponad 85\% z nich obsługiwanych jest przez przewoźników PKS. Pozostali przewoźnicy (LTZ i PKP) stanowią nieznaczny udział (odpowiednio 18 i 14 obsługiwanych przystanków). Przystanki rozchodzą się promieniście w pięciu kierunkach, umożliwiając dotarcie do Sieradza z Wielunia, Złoczewa, Błaszek, Warty, Zduńskiej Woli, Szadku, Łasku, Pabianic, Konstantynowa Łódzkiego oraz Łodzi. Zdecydowanie największą częstotliwością charakteryzuje się relacja Sieradz-Warta i dalej w kierunku Uniejowa. Najwyższy koszt dojazdu do Sieradza dotyczy przystanków w Łodzi i Pabianicach dla transportu kolejowego i Konstantynowa Łódzkiego dla PKS.

Lowicz jest ośrodkiem, w przypadku którego struktura przewoźników realizujących przewozy w zakresie jednej godziny dojazdu do miasta jest wysoce zrównoważona. Przewoźnicy PKS nieznacznie tylko dominują, obsługując 64 ze 107 wszystkich przystanków. Do odpowiednio 40 i 43 przystanków docierają busy oraz komunikacja kolejowa, zapewniając dojazd z oddalonego o $62 \mathrm{~km}$ przystanku Gawrony. Wyraźnie największe zagęszczenie miejsc zatrzymania występuje pomiędzy Łowiczem i Sieradzem. Podobne zagęszczenie ma miejsce w kierunku Brzezin oraz Łodzi przez Głowno i Stryków. Relacje z Łodzi i Skier- 
niewic odznaczają się również największą częstotliwością kursowania środków transportu, przekraczającą 40 połączeń na dobę.

W przeciwieństwie do Łowicza, Wieluń ma strukturę przewoźników wyraźnie zdominowaną przez PKS. Spośród 110 przystanków znajdujących się w zasięgu 60 minut dojazdu do miasta przewoźnik ten zapewnia obsługę 102 przystanków, odpowiadając równocześnie za dojazd z najbardziej oddalonego $(61 \mathrm{~km})$ w zasięgu godziny jazdy Bełchatowa. Przewoźnicy bus oraz PKP oferują dojazd łącznie z 20 przystanków. Największą gęstością i regularnością występowania przystanków charakteryzuje się relacja Sieradz-Złoczew-Wieluń. Jednak przeważająca częstotliwość kursowania komunikacji zbiorowej dotyczy połączenia samochodowego Wieruszów-Wieluń.

Opoczno jest ośrodkiem, do którego dotarcie w czasie jednej godziny możliwe jest z najmniejszej liczby przystanków. Spośród 69 wszystkich przystanków przedsiębiorstwa komunikacji samochodowej obsługują 59. Kolej, choć w zakresie izochrony jednogodzinnej umożliwia dotarcie do Opoczna tylko z 10 przystanków, to daje możliwość dojazdu z najdalej oddalonego przystanku $(50 \mathrm{~km})$ - Słotwiny. Największą gęstością przystanków charakteryzuje się relacja Opoczno-Sulejów oraz Opoczno-Drzewica (dodatkowo obsługiwana przez busy), będąca jednocześnie trasą o największej częstotliwości połączeń w ciągu doby.

Aleksandrów Lódzki jest ośrodkiem, w przypadku którego przejazdy w zakresie jednej godziny zapewniane są przede wszystkim przez prywatnych przewoźników typu bus. Obsługują oni ponad połowę z 102 przystanków. PKS i lokalny transport zbiorowy są względem siebie bardzo konkurencyjne, pozwalając na dotarcie do Aleksandrowa Łódzkiego odpowiednio z 42 i 45 przystanków. Zdecydowanie największe zagęszczenie przystanków występuje w kierunku Łodzi, Konstantynowa Łódzkiego oraz Ozorkowa. Ponadto, w ciągu godziny do Aleksandrowa Łódzkiego możliwe jest dotarcie ze Zgierza, Tuszyna, Uniejowa oraz Poddębic. Wyraźnie najwyższą częstotliwością połączeń charakteryzuje się relacja Poddębice-Aleksandrów Łódzki-Łódź, osiągając nawet ponad 100 połączeń na dobę.

Dojazd do Ozorkowa możliwy jest każdym z poddanych analizie środków transportu. 119 przystanków w zakresie izochrony jednogodzinnej obsługiwanych jest w 47 przypadkach przez PKS, 31 przez lokalnych przewoźników, 28 przez busy, a 18 przystanków znajduje się na liniach kolejowych. Wyraźnie widoczne jest grupowanie się przystanków na osi północ-południe od Krośniewic/Kutna do Łodzi. Wyjątek stanowi jedynie grupa przystanków kolejowych pomiędzy Zgierzem i Głownem. Największe zagęszczenie miejsc zatrzymania komunikacji zbiorowej występuje w relacji Ozorków-Łódź i związane jest w dużej mierze z linią tramwajową. W ramach izochrony jednogodzinnej najdalej wysuniętym przystankiem (kolejowym) są Ostrowy (48 km). Najwyższa częstotliwość kursowania komunikacji zbiorowej dotyczy trasy Łęczyca-Ozorków-Lódź, osiągająca zakres 100-150 połączeń na dobę. 
Analiza przeprowadzona dla Lasku wskazuje wyraźną dominację przewozów realizowanych przez PKS. Z grupy wszystkich 132 przystanków, z których teoretyczny czas dojazdu do Łasku nie przekracza jednej godziny, przedsiębiorstwa komunikacji samochodowej zapewniają dojazd do 107. Lokalni przewoźnicy docierają jedynie do 12 przystanków, natomiast skorzystanie z połączeń kolejowych do Łasku jest możliwe w 23 miejscach. Również w przypadku Łasku, dzięki podróży pociągiem możliwe jest dotarcie do miasta $\mathrm{z}$ najdalszego w zakresie jednej godziny przystanku $(52 \mathrm{~km})$ - Skalmierz. Zdecydowanie najgęstszą siecią przystanków charakteryzuje się odcinek drogi krajowej nr 12 pomiędzy Łaskiem a Zduńską Wolą. Natomiast najczęstsze połączenia realizowane są z Pabianic.

Przypadek Konstantynowa Lódzkiego, ze względu na swoje bezpośrednie sąsiedztwo z Łodzią, charakteryzuje się wysokim udziałem obsługi przystanków przez lokalny transport zbiorowy (MPK Łódź). Spośród 139 wszystkich przystanków jego autobusy docierają do 46\%. Niemalże ten sam poziom dostępności zapewnia PKS. Prywatni przewoźnicy w przeciwieństwie do sąsiedniego Aleksandrowa Łódzkiego obejmują najmniejszą liczbę przystanków (41). Największe zagęszczenie miejsc zatrzymania komunikacji zbiorowej dotyczy Łodzi oraz Aleksandrowa i związane jest z funkcjonowaniem linii autobusowych Miejskiego Przedsiębiorstwa Komunikacyjnego w Łodzi. Przewoźnik ten zapewnia również najwyższą częstotliwość połączeń. Ponadto w czasie 60 minut możliwe jest dotarcie do Konstantynowa Łódzkiego z Poddębic, Szadku, Sieradza, Zduńskiej Woli oraz Pabianic.

W obszarze wyznaczonym przez jednogodzinną izochronę dojazdu do Rawy Mazowieckiej znalazło się 95 przystanków. Każdy z nich obsługiwany jest zarówno przez PKS, jak i busy. Bezpośrednie połączenia pozwalają na dotarcie do miasta z Łodzi, Brzezin, Koluszek, Skierniewic, Tomaszowa Mazowieckiego oraz Białej Rawskiej. Najczęściej kursujące autobusy i busy poruszają się po trasie Skierniewice-Rawa Mazowiecka-Tomaszów Mazowiecki, a ich częstotliwość przekracza 40 kursów na dobę.

W przypadku Lęczycy zinwentaryzowano 83 przystanki. 19 z nich zapewnia dostęp do sieci kolejowej, niemalże wszystkie pozostałe są w równym stopniu obsługiwane przez PKS (64) i prywatnych przewoźników (60). Najdalej (w ujęciu odległości fizycznych rzeczywistych) położonym punktem, z którego podróż do Łęczycy nie przekracza 60 minut, jest stacja Łowicz Główny $(70 \mathrm{~km})$. Z czterech głównych kierunków, z których prowadzą połączenia bezpośrednie (Krośniewice, Kutno, Poddębice, Łódź), wyraźnie największa częstotliwość kursów występuje w relacji Łódź-Zgierz-Ozorków-Łęczyca (ponad 40 połączeń na dobę).

Do Głowna w czasie 60 minut możliwy jest dojazd ze 133 przystanków, obsługiwanych przez przewoźników PKS (65), bus (47) oraz PKP (27). Z największą gęstością występują one na drodze krajowej nr 14 pomiędzy Głownem i Łodzią oraz Strykowem i Zgierzem na drogach wojewódzkich nr 708 i 702 . Analiza częstotliwości kursowania środków transportu zbiorowego wyraźnie wskazuje na oś Łowicz-Głowno-Stryków-Lódź, która odznacza się na tle pozostałych relacji 

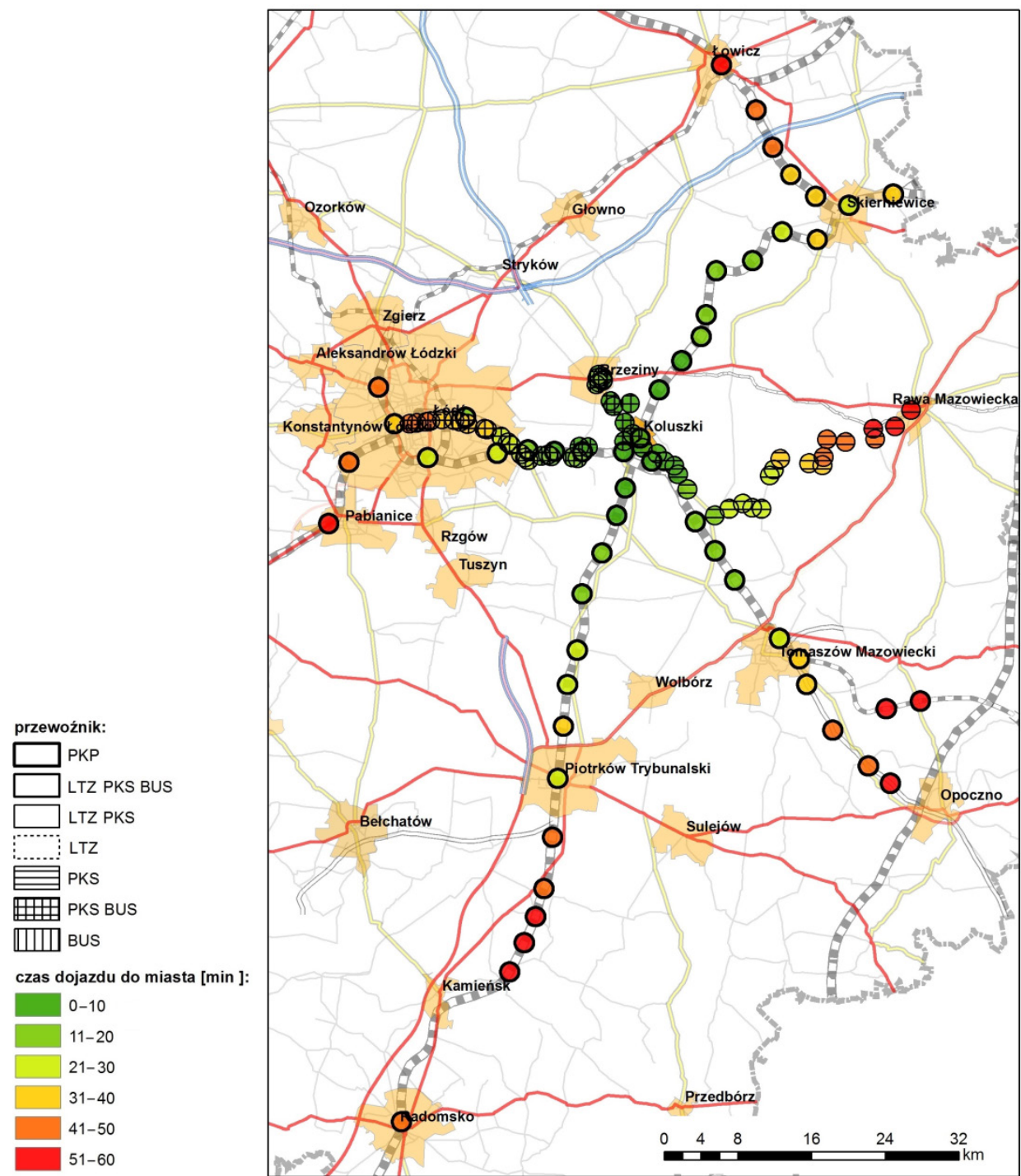

Rycina 3.16. Rodzaj przewoźnika oraz czas dojazdu do Piotrkowa Trybunalskiego w zakresie izochrony jednogodzinnej

Źródło: opracowanie własne

znacznie wyższą liczbą połączeń, osiągającą ponad 100 kursów. Koszt dojazdu nawet z najbardziej oddalonych od Główna przystanków (kolejowych) nie przekracza 15 zł. 
Koluszki są ośrodkiem wyróżniającym się wśród wszystkich miast województwa łódzkiego. Spośród 112 przystanków w zasięgu izochrony jednogodzinnego dojazdu, 53 są infrastrukturą kolejową. Zapewnia to Koluszkom zdecydowanie największy obszar, wyznaczony izochroną jednogodzinnej jazdy koleją (rycina 3.16).

Połączenia kolejowe pozwalają m.in. na dotarcie z oddalonego o $70 \mathrm{~km} \mathrm{Ra-}$ domska na południu czy oddalonego o $61 \mathrm{~km}$ Łowicza na północy. Uzupełnieniem oferty przewozowej są połączenia oferowane przez spółki PKS, obsługujące 59 przystanków w relacji z Brzezinami, Łodzią i Rawą Mazowiecką oraz prywatnych przewoźników typu bus (36 przystanków), zwiększających częstotliwość połączeń z Brzezin i Łodzi. Te dwie trasy odznaczają się w związku z tym najwyższą liczbą połączeń w ciągu doby (ponad 40). Możliwość dojazdu ze znacznie oddalonych obszarów pociąga za sobą wysokie ceny biletów, dla przykładu podróż z Radomska pozwalająca dojechać do Koluszek w ciągu godziny będzie kosztować podróżnego ponad $25 \mathrm{zł}$.

Brzeziny, podobnie jak znacznie większe Radomsko, w zasięgu wyznaczonej izochrony posiadają 100 przystanków. Przeważająca ich część (83 przystanki) powiązana jest z Brzezinami dzięki usługom PKS. Lokalni przewoźnicy i przewoźnicy typu bus obsługują odpowiednio 25 i 20 punktów. Najgęstsza sieć przystanków występuje pomiędzy Brzezinami i Łodzią, co wynika w dużej mierze z funkcjonującej na tej drodze linii MPK Łódź. Podobną gęstością charakteryzuje się również połączenie Koluszki-Brzeziny, będące dodatkowo połączeniem o najwyższej częstotliwości kursowania autobusów i busów. Do Głowna, Łowicza, Skierniewic i Rawy Mazowieckiej nie kursuje więcej niż 20 autobusów na dobę.

Peryferyjne położenie Wieruszowa uwidacznia się również przy analizie funkcjonowania transportu zbiorowego. W ciągu 60 minut możliwe jest bezpośrednie dotarcie do miasta z zaledwie 39 przystanków. Przedsiębiorstwa komunikacji samochodowej obsługują $31 \mathrm{z}$ nich, umożliwiając dotarcie z Wielunia i Złoczewa. Wykorzystując połączenia kolejowe, w ciągu godziny możliwe jest dotarcie do Wieruszowa jedynie z Wielunia. Pomiędzy tymi miastami gęstość przystanków jest zdecydowanie największa, natomiast częstotliwość połączeń nie przekracza 20 kursów na dobę.

Żychlin, pomimo również peryferyjnego położenia, w ciągu godziny jest bezpośrednio dostępny z 64 przystanków. Wynika to przede wszystkim z jego położenia $\mathrm{w}$ regionalnej sieci połączeń kolejowych. Bowiem 31 przystanków obsługiwanych jest przez przewoźników kolejowych, oferując dojazd do Żychlina z Ozorkowa, Łęczycy, Kutna, Łowicza i Skierniewic. Przedsiębiorstwa komunikacji samochodowej docierają do 33 przystanków i obsługują trasę pomiędzy Kutnem a Żychlinem oraz Łodzią i Żychlinem, do samej Łodzi jednak w ciągu godziny nie docierając. Przystanki autobusowe charakteryzują się wyraźnie większą gęstością występowania na drodze krajowej nr 92 oraz wojewódzkiej nr 583 
i 703. Ponadto autobusowe połączenie Kutno-Żychlin charakteryzuje się najwyższą częstotliwością kursów.

W przypadku Zelowa do badania włączono 74 przystanki. Znaczą większość (69) obsługuje PKS. Dodatkowo pomiędzy Zduńską Wolą a Zelowem realizowane jest połączenie przez lokalnego przewoźnika (14 przystanków). Natomiast pomiędzy Bełchatowem i Zelowem kursują również busy (22 przystanki) i jest to relacja o największym zagęszczeniu przystanków. Natomiast największa częstotliwość połączeń występuje z Łasku, nie przekracza jednak 20 połączeń na dobę.

Poddębice w zakresie izochrony jednogodzinnej posiadają 129 przystanków umożliwiających bezpośrednie połączenie z miastem. 66\% miejsc zatrzymania transportu zbiorowego obsługiwanych jest przez spółki PKS, 38\% przez przewoźników lokalnych, a 43\% przez prywatnych przewoźników typu bus. Podkreślić należy wysoką gęstość przystanków w każdym z realizowanych kierunków. Najdłuższe połączenie $(48 \mathrm{~km})$, prowadzące $\mathrm{z}$ Lutomierska (przystanek 3-go Maja), realizowane jest przez przedsiębiorstwo komunikacji samochodowej w Łodzi. Najczęściej autobusy i busy docierają do Poddębic z Łodzi - częstotliwość przekracza 40 połączeń na dobę. Podczas gdy z Łęczycy, Uniejowa, Sieradza i Szadku dociera nie więcej niż 30 kursów dziennie.

Spośród 42 przystanków, w izochronie jednogodzinnej Tuszyna, z każdego do miasta dotrzeć można autobusem PKS, a dodatkowo w relacji Łódź-RzgówTuszyn-Piotrków Trybunalski-Sulejów kursują również busy. Jest to też relacja o najwyższej częstotliwości połączeń, która narasta dodatkowo wraz ze zbliżaniem się do Łodzi.

Przystanki, z których możliwy jest dojazd do Pajęczna w ciągu 60 minut, skupiają się w trzech kierunkach - z Wielunia, Bełchatowa/Zelowa oraz Radomska, w przypadku którego regularność ich występowania jest największa. Wszystkie 78 przystanków funkcjonuje w oparciu o przedsiębiorstwa komunikacji samochodowej. Najsilniejsza relacja w rozumieniu częstotliwości połączeń łączy Pajęczno z Działoszynem.

Bardzo podobna sytuacja dotyczy Sulejowa. Liczba wszystkich przystanków wynosi w jego przypadku 81. Również zgrupowane są w trzech głównych kierunkach, na trasie z Tuszyna przez Piotrków Trybunalski, z Przedborza oraz Opoczna. Dodatkowo pomiędzy Sulejowem i Piotrkowem Trybunalskim kursują busy. Najwyższa częstotliwość połączeń, osiągająca na odcinku drogi krajowej nr 12 nawet 200 kursów na dobę, występuje w relacji Tuszyn-Piotrków TrybunalskiSulejów-Opoczno (rycina 3.17). Najbardziej oddalonym (w ujęciu odległości fizycznych rzeczywistych) przystankiem jest Bełchatów, z którego do Sulejowa można dotrzeć pośpiesznym połączeniem PKS.

W przypadku Działoszyna zinwentaryzowano 71 przystanków. Z każdego z nich dojazd do Działoszyna zapewniają autobusy PKS. Podobnie jak w przypadku Pajęczna i Sulejowa, przystanki skupione są w obrębie trzech głównych kierunków: ze Złoczewa (do samego miasta jednak nie docierając), z Pajęczna 


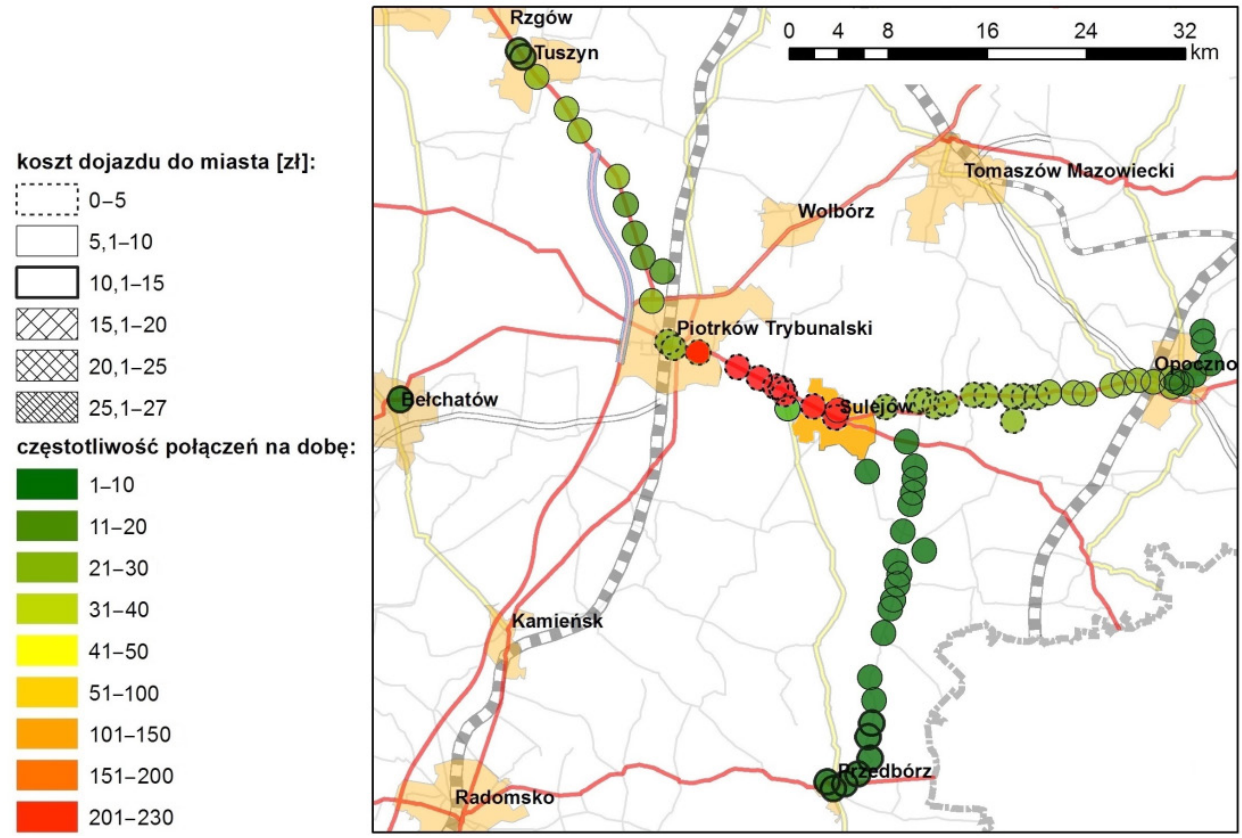

Rycina 3.17. Częstotliwość oraz koszt dojazdu do Sulejowa w zakresie izochrony jednogodzinnej Źródło: opracowanie własne

oraz z północy z Woli Kleszczowej. Największa częstotliwość połączeń występuje w przypadku wspomnianej już wcześniej relacji Działoszyn-Pajęczno.

Peryferyjne położenie Krośniewic powoduje, iż bezpośrednie połączenia w zakresie jednej godziny dotyczą przystanków w relacji Kutno-Krośniewice oraz Łódź-Zgierz-Ozorków-Lęczyca-Krośniewice. Takie położenie skutkuje również nieliczną grupą przystanków, jest ich zaledwie 34. Wszystkie obsługiwane są przez autobusy PKS, a na drodze krajowej nr 91 dodatkowo kursują prywatni przewoźnicy, nie przekraczając 40 połączeń w ciągu doby.

Lokalizacja przystanków w zakresie izochrony jednogodzinnego dojazdu do Drzewicy wskazuje na silne połączenie z Opocznem. Jest to relacja obsługiwana przez autobusy PKS. Kolej zapewnia zaś połączenie z Tomaszowem Mazowieckim i dojazd z najbardziej oddalonego przystanku w zakresie wyznaczonej izochrony - Wykna (52 km). Przejazd do Drzewicy jest jednak możliwy nie więcej niż 20 razy na dobę.

Przedbórz, będąc miastem mniejszym od Drzewicy, w zasięgu 60-minutowej izochrony posiada niemalże dwukrotnie więcej przystanków (80). Pozwalają one na dotarcie do miasta autobusem lub busem z Radomska oraz wyłącznie autobusem z Sulejowa, okolic Piotrkowa Trybunalskiego (przystanek Uszczyn) 
i okolic Kamieńska (przystanek Gorzędów). Równoczesne funkcjonowanie prywatnych przewoźników i spółek PKS w relacji z Radomskiem skutkuje najwyższą dla Przedborza częstotliwością połączeń.

Dojazd do Strykowa możliwy jest każdym z czterech analizowanych rodzajów przewoźników. W ciągu godziny miasto jest dostępne z Pabianic, Łodzi, Zgierza, Głowna oraz Łowicza. Najdłuższe połączenia (np. do przystanku Zosinów oddalonego o $55 \mathrm{~km}$ ) realizowane są przez kolej. Natomiast najgęstsza sieć przystanków dotyczy połączeń ze Zgierzem oraz Łodzią, co wynika z funkcjonowania na tej trasie przewozów PKS, bus oraz MPK Łódź. Gwarantuje to również najczęstsze połączenia w ciągu dnia.

W przeciwieństwie do Strykowa, do Zloczewa dojazd w zakresie jednej godziny umożliwiają jedynie przewoźnicy PKS. Wyraźnie najwyższe zagęszczenie miejsc zatrzymania autobusów występuje w relacji Sieradz-Złoczew-Wieluń. Jest to relacja o najwyższych $\mathrm{w}$ przypadku Złoczewa częstotliwościach realizowanych połączeń. Szczególnie dotyczy to połączenia z Sieradza. Pojedyncze przystanki dostępne w czasie jednej godziny w Wieruszowie, Błaszkach, Warcie, Zduńskiej Woli oraz Łasku są wynikiem funkcjonowania na tych kierunkach połączeń pośpiesznych.

W przypadku Rzgowa bardzo ważną rolę w realizacji transportu zbiorowego odgrywają lokalni przewoźnicy - Miejskie Przedsiębiorstwo Komunikacyjne w Łodzi oraz Miejski Zakład Komunikacyjny w Pabianicach, którzy łącznie obsługują trzy czwarte ze wszystkich 88 przystanków. Usługi przewozowe świadczą również spółki PKS oraz prywatni przewoźnicy bus, dzięki którym do Rzgowa w czasie nieprzekraczającym godziny możliwe jest dotarcie z Tuszyna oraz Tomaszowa Mazowieckiego. Poza znacznym udziałem w przewozach lokalnych przewoźników, Rzgów charakteryzuje się również wysokimi częstotliwościami realizowanych połączeń, szczególnie z Tuszyna i Łodzi, gdzie ich liczba przekracza 150 kursów na dobę.

Jak wynika z przeprowadzonej analizy, Warta w zasięgu izochrony jednogodzinnej obsługiwana jest wyłącznie przez autobusy PKS. Przewoźnicy Ci zapewniają bezpośrednie dotarcie z Błaszek, Sieradza, Złoczewa oraz Szadku. Przedsiębiorstwa komunikacyjne gwarantują również przejazd z Lutomierska (kierunek Konstantynów Łódzki) oraz Porczyn (kierunek Poddębice). Najsilniejsze połączenie w rozumieniu częstotliwości kursów łączy Wartę z Sieradzem.

Również Biała Rawska w ujęciu bezpośrednich połączeń w zakresie jednej godziny dojazdu obsługiwana jest wyłącznie przez przedsiębiorstwa komunikacji samochodowej. Analiza lokalizacji przystanków wskazuje, że w ciągu 60 minut do Białej Rawskiej możliwe jest dotarcie jedynie z Rawy Mazowieckiej. Miejsca zatrzymania autobusów na trasie pomiędzy tymi ośrodkami charakteryzują się najwyższą częstotliwością kursowania środków transportu.

W zakresie 60 minut dojazdu do Uniejowa zlokalizowanych jest 76 przystanków, z których dojazd zapewnia PKS, a 32 z nich (w relacji Uniejów-Poddębice- 
Aleksandrów Łódzki) dodatkowo obsługują busy. Jest to też relacja o najwyższej częstotliwości połączeń. Uniejów w czasie godziny jest też dostępny z Łęczycy oraz Kazimierza (kierunek Konstantynów Łódzki).

Spośród najmniejszych miast województwa łódzkiego, Kamieńsk w zakresie wyznaczonej izochrony dostępny jest z największej liczby przystanków (116). Ponadto przejazd do miasta możliwy jest za pośrednictwem każdego z czterech rodzajów przewoźników. Kamieńsk jest dostępny z Piotrkowa Trybunalskiego oraz Radomska, a połączenia z nimi można uzyskać podróżując autobusem, busem czy też koleją. W czasie godziny możliwy jest też dojazd z Bełchatowa oraz przedmieść Przedborza (przystanek Dęba). Należy zwrócić uwagę, że pomimo tak dobrze wykształconej sieci punktowych elementów infrastruktury transportowej, częstotliwość połączeń nie przekracza 20 kursów na dobę w żadnej z relacji.

W przeciwieństwie do Kamieńska, Wolbórz odznacza się najmniejszą liczbą przystanków w izochronie jednogodzinnej. Bezpośrednio można do niego dotrzeć zaledwie z 18 przystanków, z których każdy obsługiwany jest przez PKS, a 7 dodatkowo przez busy. Pozwala to na dotarcie do Wolborza z Bełchatowa, Piotrkowa Trybunalskiego oraz Tomaszowa Mazowieckiego, z którym łączy Wolbórz największa dzienna liczba połączeń.

Nieznacznie mniejsze od Wolborza Blaszki posiadają niemalże trzykrotnie większą sieć przystanków w izochronie jednogodzinnej. Bezpośrednie połączenia z Warty, Szadku oraz Złoczewa zapewniają autobusy PKS. Z Sieradza można dotrzeć również koleją, co sprawia, że w tej relacji sieć przystanków jest wyraźnie najgęstsza. Dotrzeć do Błaszek można również ze Zduńskiej Woli oraz Łasku, ale wyłącznie koleją, jeśli podróż ma nie zająć więcej niż godzinę. Częstotliwość połączeń niezależnie od relacji nie przekracza 20 kursów na dobę.

Szadek, będąc najmniejszym miastem województwa łódzkiego, ma jednak sieć przystanków w zasięgu godziny jazdy komunikacją zbiorową na poziomie Łęczycy. Autobusy PKS dowożą pasażerów do Szadku z Sieradza, Warty, Zduńskiej Woli, Łasku, Poddębic, Konstantynowa Łódzkiego oraz Łodzi. Powoduje to „rozchodzenie się” przystanków promieniście z Szadku w pięciu kierunkach. Największa częstotliwość dotyczy połączeń z Łodzi przez Konstantynów Łódzki. 


\section{DOSTĘPNOŚĆ TRANSPORTOWA MIAST W ŚWIETLE TRANSPORTU INDYWIDUALNEGO}

\subsection{Dostępność transportowa w ujęciu teoretycznym}

Coraz większa świadomość konieczności promowania transportu zbiorowego i liczne zabiegi w tym zakresie (szczególnie w miastach) nie wpływają na ograniczenie znaczenia transportu indywidualnego w Polsce. Od lat uwidacznia się spadek przewozów w transporcie zbiorowym, czego przyczyn należy upatrywać m.in. w większym, codziennym komforcie podróżowania, własnym środkiem transportu. Skutkuje to zazwyczaj wzrostem kongestii, która widoczna jest w szczególności na drogach dojazdowych i w centrach dużych miast w godzinach szczytu komunikacyjnego (Diagnoza polskiego transportu 2011).

Dostępność transportową miast województwa łódzkiego w ujęciu transportu indywidualnego określono na podstawie czasów i kosztów podróży, jakie zmuszony jest ponieść podróżujący samochodem osobowym pomiędzy tymi ośrodkami. Pominięto na tym etapie rozważania nad odległościami fizycznymi, po pierwsze ze względu na to, że zostały one szczegółowo omówione w części pracy poświęconej wyposażeniu infrastrukturalnemu, a po drugie ze względu na ich coraz bardziej marginalne znaczenie w wyborach podróżujących. W praktyce bowiem niejednokrotnie opłacalne jest wydłużenie drogi przejazdu, aby móc osiągnąć wyższą prędkość i wykonać zadania przewozowe w krótszym czasie. Występuje wtedy zjawisko substytucji, czyli możliwości zastępowania odległości przestrzennej odległością czasową (Gęsiarz 1982).

Pomiar czasu przejazdu w transporcie indywidualnym to skomplikowane zadanie. Parametr ten jest determinowany wieloma czynnikami - warunkami atmosferycznymi, nieprzewidzianymi zdarzeniami na drodze (np. wypadki) czy indywidualnymi cechami kierowców, a ponadto jest zmienny zarówno w rozkładzie dobowym, tygodniowym, jak i rocznym. W związku z tym zdecydowano się przeprowadzić badania czasu dojazdu w różnych ujęciach.

Pierwszy wariant badania czasów przejazdu pomiędzy miastami województwa łódzkiego zakłada tylko jedną determinantę warunkującą szybkość poruszania się pojazdów - ograniczenia prędkości wynikające z Prawa o ruchu drogo- 
$w y m^{1}$. Określono zatem czas jazdy netto, nie uwzględniając $\mathrm{w}$ badaniu ani przerw wynikających z warunków na drodze, ani takich, jak odpoczynki dla kierowcy czy tankowanie. Przyjęto, że ruch odbywa się z maksymalnymi dopuszczalnymi prędkościami po trasach umożliwiających najkrótszy czas przejazdu pomiędzy daną parą miast. W związku z tym brano pod uwagę również przejazdy płatnymi odcinkami autostrad, co zostało uwzględnione w dalszej analizie kosztów podróży. Określając dostępność, każdorazowo poszukiwano drogi najkrótszej w sensie czasowym, co nie zawsze pokrywało się z najkrótszą drogą według odległości fizycznej rzeczywistej. Pomiarów dokonano, korzystając ze szczegółowych map samochodowych i planów miast, analizując odległości z rozbiciem na odcinki według kategorii dróg, a następnie przeliczono te dane na minuty. Cały proces zoptymalizowano, wykorzystując aplikację AutoMapa Polski 6.14a 1306. Badanie przeprowadzono w lutym $2013 \mathrm{r}$.

W ujęciu topologicznym analizę dostępności miast województwa łódzkiego wykonano w oparciu o położenie ośrodków w wyznaczonych izochronach dojazdu. Dla każdego z miast skonstruowano izolinie czasu dojazdu w zakresie do 15 minut, od 16 do 30 minut, od 31 do 45 minut, od 46 do 60 minut oraz powyżej godziny (rycina 4.1). Podróż nie dłuższa niż kwadrans zapewnia dotarcie z największej liczby miast (10) do Łodzi. Jest to ośrodek, który wyraźnie wyróżnia się, ponieważ do pozostałych miast województwa w tak określonym czasie dotrzeć można nie więcej niż z sześciu ośrodków, jak w przypadku Konstantynowa Łódzkiego, czy z pięciu miast, jak w przypadku Pabianic, Zgierza i Łasku. Za to do Wielunia, Wieruszowa oraz Przedborza w czasie 15 minut niemożliwe jest dotarcie z żadnego innego miasta. Najliczniejszą grupę (16 ośrodków) stanowią miasta dostępne $\mathrm{w}$ zakresie kwadransa jedynie $\mathrm{z}$ jednego miasta.

Przy przedłużeniu hipotetycznej podróży do 30 minut nadal najbardziej dostępnym miastem jest Łódź (w sumie dostępna jest z 18 ośrodków). Wysoki poziom dostępności charakteryzuje również Zgierz (14 miast). Jest to również jedno z miast o najwyższej liczbie połączeń w zakresie 16-30 minut. Z 9 miast można dotrzeć w tym czasie również do Aleksandrowa Łódzkiego, Ozorkowa, Brzezin, Poddębic oraz Szadku. Żadne połączenie w tym przedziale czasowym nie jest możliwe do Drzewicy. Jest to też ośrodek, który podobnie jak Wieruszów, w czasie półgodzinnej jazdy samochodem dostępny jest wyłącznie z jednego miasta.

W czasie nieprzekraczającym 45 minut najlepiej dostępnymi ośrodkami są Łódź i Pabianice, do których dojazd możliwy jest odpowiednio z 28 i 24 innych miast. Natomiast największy „,przyrost dostępności” w stosunku do półgodzinnego zakresu jazdy odnotował Zelów (w zakresie 31-45 minut dostępny z 14 miast) oraz Zduńska Wola (przyrost o 13 miast). Niezmiennie najniższym poziomem dostępności odznacza się Wieruszów. W czasie do 45 minut dojazd do niego jest

${ }^{1}$ Ustawa z dnia 20 czerwca 1997, Dz.U. 1997, nr 98, poz. 602 wraz z późn. zm. 


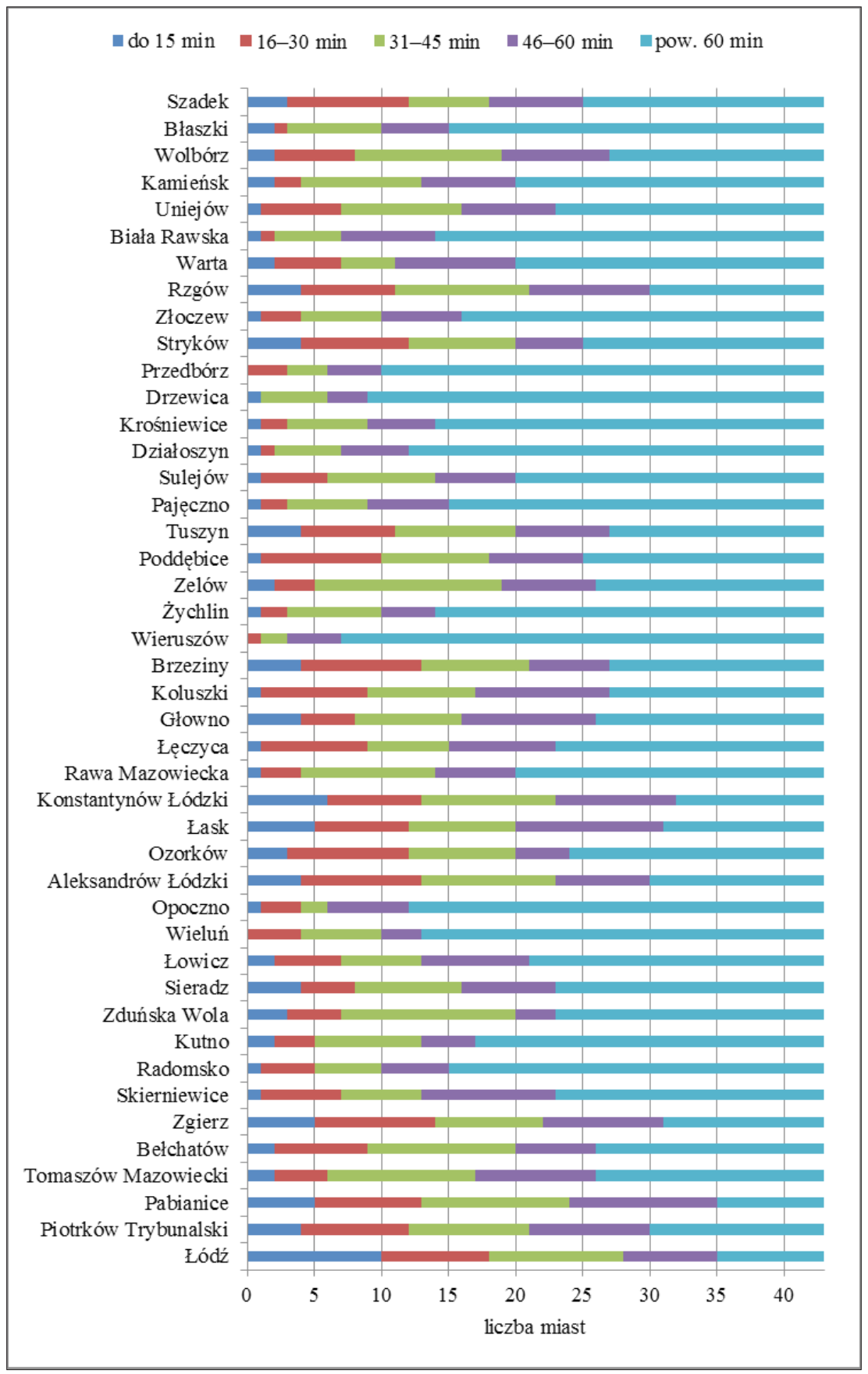

Rycina 4.1. Liczba ośrodków w izochronach dojazdu samochodem osobowym do miast województwa łódzkiego

Źródło: opracowanie własne 
możliwy zaledwie z 3 miast. Razem z Opocznem odnotowały w tym przedziale czasowym wzrost liczby dostępnych ośrodków o 2 .

Założenie jazdy nie dłużej niż godzinę nie zmienia sytuacji miast najlepiej i najgorzej dostępnych - nadal są to odpowiednio Łódź i Pabianice oraz Wieruszów. W zakresie 46-60 minut jazdy, największą grupą możliwych do osiągnięcia celów posiadają Pabianice oraz Łask (po 11 miast). Natomiast w przypadku Zduńskiej Woli, Wielunia i Drzewicy dłuższa podróż powoduje wzrost dostępności jedynie o 3 miasta.

W grupie miast dostępnych przy założeniu jazdy powyżej jednej godziny występuje największe zróżnicowanie (odchylenie standardowe przekracza 7 połączeń). Bowiem w przypadku Łodzi, w tej grupie znalazło się jedynie 8 jednostek, a do Wieruszowa czy Drzewicy dojazd w tym czasie możliwy jest odpowiednio z 36 i 34 miast województwa. Te dwa wymienione miasta dzieli również największa odległość wyrażona w jednostkach czasu. Podróżni poruszający się samochodem osobowym zmuszeni są do jazdy teoretycznie trwającej ponad 150 minut, aby dotrzeć z jednego do drugiego ośrodka.

Analizując dostępność wzajemną miast województwa łódzkiego w transporcie samochodowym, zauważyć należy, że najkrótsze czasy przejazdów występują zawsze pomiędzy ośrodkami położonymi najbliżej siebie - czynnik determinujący dostępność to odległość, a nie stan infrastruktury. Najwięcej relacji o zadowalającym czasie przejazdu (do 60 minut) zanotowano do miast położonych w centrum województwa, w granicach Łódzkiego Obszaru Metropolitalnego. Na 8 miast, do których dojazd w tym zakresie czasu jest możliwy z nie mniej niż 30 ośrodków, jedynie Piotrków Trybunalski nie wpisuje się w tę prawidłowość.

Dostępność transportowa jest ważną miarą obrazującą integralność przestrzeni społeczno-gospodarczej województwa łódzkiego. W idealnym kształcie układ izochron wokół każdego z miast powinien być możliwie koncentryczny. W przypadku województwa dostępność za pomocą sieci drogowej do poszczególnych miast pozostaje nierównomierna. Jest to pochodna niezakończonego procesu inwestycyjnego (przy braku jakichkolwiek autostrad i dróg ekspresowych, układ byłby koncentryczny). Po części jednak przyczyn takiego stanu rzeczy szukać należy w sformułowanych jeszcze w latach siedemdziesiątych XX w. założeniach rozwoju sieci. Przyjęty w tamtym czasie model szachownicowy sprzyja powstawaniu obszarów gorszej dostępności (Diagnoza polskiego transportu 2011). Jest to szczególnie dobrze widoczne w relacjach prowadzących do Wieruszowa (rycina 4.2).

Dotyczy to głównie miast, przez które przebiega droga ekspresowa S8. Znaczne zniekształcenia występują również w związku z przebiegiem odcinka autostrady A2 na wschód od Strykowa. Nie jest ono jednak tak wyraźne jak to wynikające z przebiegu drogi ekspresowej, ponieważ autostrada nie przebiega bezpośrednio przez miasta, co skutkuje dodatkowymi przejazdami po drogach ogólnodostępnych i zmniejsza zaoszczędzony na autostradzie zasób czasu. 


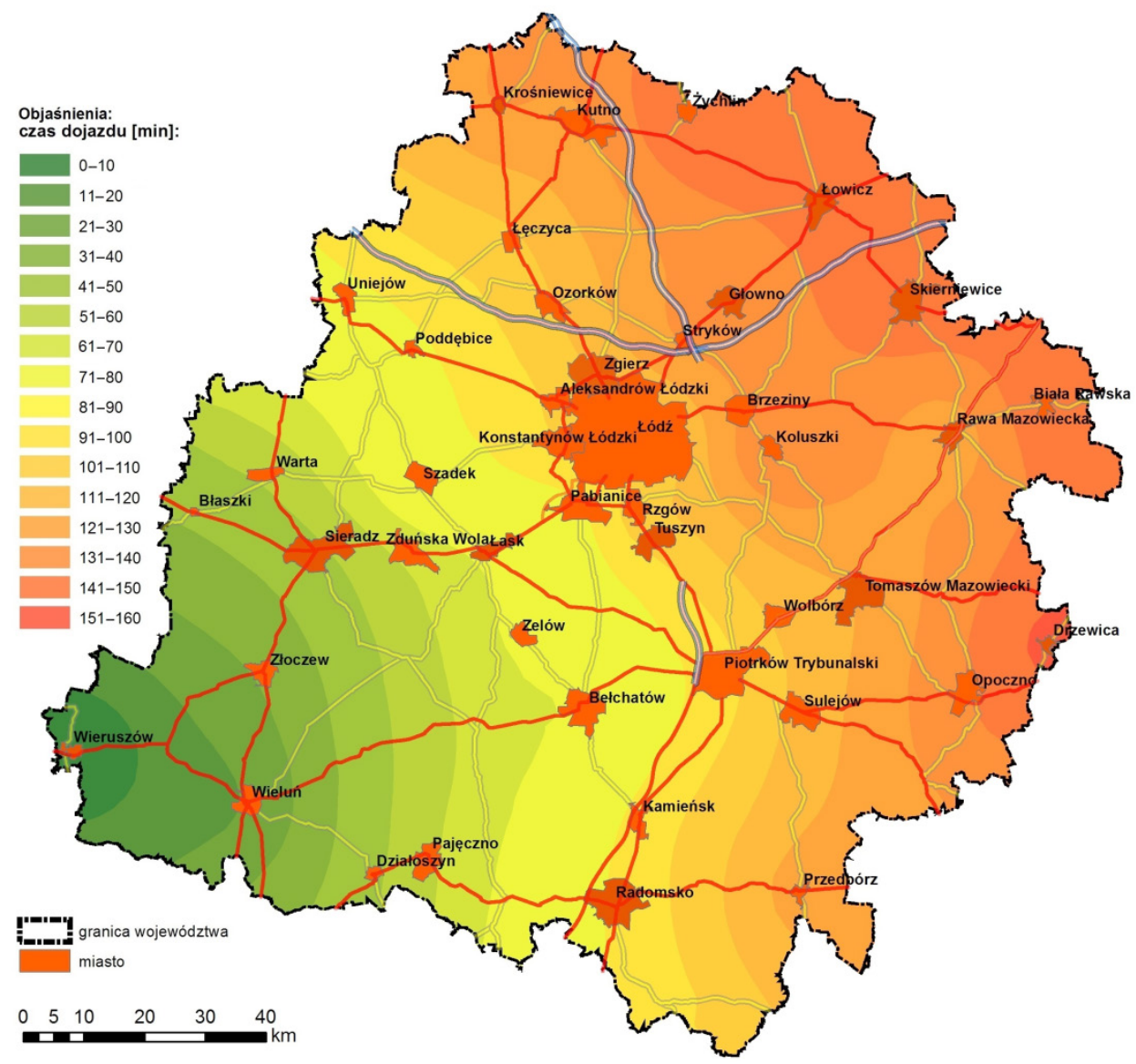

Rycina 4.2. Czas dojazdu do Wieruszowa przy założeniu poruszenia się samochodem osobowym z maksymalną dozwoloną prędkością

Źródło: opracowanie własne

Wyraźnie lepsza sytuacja występuje w przypadku najlepiej dostępnej Łodzi (rycina 4.3). Dojazd do najbardziej oddalonego Wieruszowa nieznacznie tylko przekracza półtorej godziny. Układ izochron dla Łodzi jest bardziej regularny i wyraźniej zbliżony do koncentrycznych okręgów, bowiem główne drogi rozchodzą się promieniście w każdym z kierunków. Niemniej jednak warunki techniczne poszczególnych dróg i układ, w jakim pozostają względem siebie, przyczynia się do pewnych deformacji. Zniekształcenia izochron występują najwyraźniej w związku z przebiegiem drogi krajowej nr 1 i 91 na południe od Łodzi oraz odcinków autostrad A1 i A2 na północ, wschód i zachód województwa. Widoczna jest również anomalia towarzysząca odcinkowi drogi ekspresowej S14 oraz drogi krajowej nr 14. 


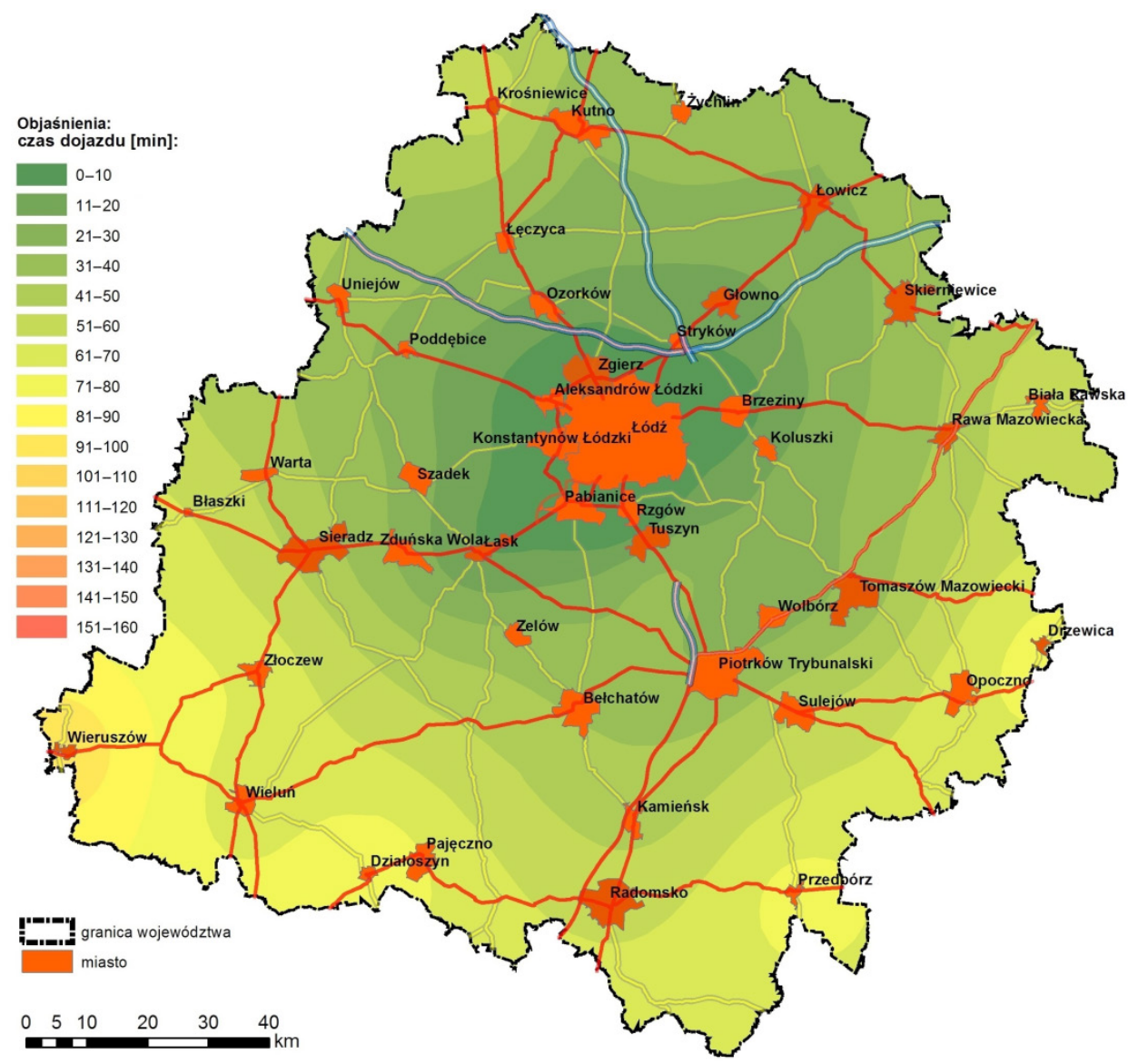

Rycina 4.3. Czas dojazdu do Łodzi przy założeniu poruszenia się samochodem osobowym z maksymalną dozwoloną prędkością

Źródło: opracowanie własne

Dostępność miast województwa łódzkiego w ujęciu transportu indywidualnego oceniono również pod względem kosztów przejazdu. W ich przypadku ważne jest poza samą długością pokonywanej drogi, również wzięcie pod uwagę innych kwestii. Rozpatrzyć należy koszty stałe i zmienne, wysiłek towarzyszący podróży, a ponadto jej komfort i bezpieczeństwo. Są to jednak zmienne trudne do zmierzenia w ujęciu ilościowym. Problemem pojawiającym się przy szacowaniu uogólnionego kosztu podróży jest również wycena czasu w kategoriach pieniężnych. Ludzie w różny sposób wyceniają czas podróży. $Z$ tego względu dostępność powinna być wówczas liczona oddzielnie dla każdej kategorii społecznej².

${ }^{2}$ Uczestnicy ruchu wyceniają swój czas podróży przede wszystkim w zależności od otrzymywanego dochodu oraz wyceny własnego czasu wolnego (Rosik i in. 2012). 
Czas podróży jest najczęściej wykorzystywanym elementem oporu przestrzeni w badaniach dostępności. Nie jest jednak jedynym. Trudność pokonania dystansu między źródłem a celem podróży może być mierzona na kilka sposobów. W bardziej zaawansowanych pracach transportowych wykorzystuje się pojęcie tzw. uogólnionego kosztu podróży (Geurs, Ritsema van Eck 2001). Koszt uogólniony jest sumą trzech elementów, tj. czasu, kosztu oraz wygody podróżowania. Każdy z wyżej wymienionych elementów złożony jest $\mathrm{z}$ dodatkowo $\mathrm{z}$ kilku składowych (Rosik i in. 2012).

Na potrzeby niniejszej pracy koszty przejazdu pomiędzy każdą parą miast ustalono jako sumę kosztów stałych i zmiennych eksploatacji pojazdów oraz kosztów związanych z opłatami za przejazd. W tym zakresie wykorzystano metodologię wypracowaną przez zespół pod kierownictwem dr. Piotra Rosika na potrzeby Monitoringu spójności terytorialnej gmin w skali krajowej i międzynarodowej w latach 1995-2030. W Instrukcji oceny efektywności ekonomicznej przedsięwzięć drogowych i mostowych dla dróg wojewódzkich (2008), wykonanej przez Instytut Badawczy Dróg i Mostów, wyróżniono dwa rodzaje kosztów stałych eksploatacji pojazdów. Pierwsze z nich powiązano z przebiegiem pojazdu, uwzględniając: koszty amortyzacji, koszty obsługi technicznej i napraw bieżących oraz koszty ogumienia. Do drugiej grupy (dotyczącej czasu pracy) włączono koszty ubezpieczeń komunikacyjnych, opłaty, podatki oraz koszty czynności cywilnoprawnych związanych z obsługą pojazdu.

Specjaliści IGiPZ PAN, podchodząc krytycznie do szacunków kosztów eksploatacji uzależnionych od przebiegu pojazdu sporządzonych przez pracowników IBDiM, określili koszt zgodnie z własną metodologią. Według danych Instytutu SAMAR, średnia wartość nowego samochodu kupionego i zarejestrowanego w Polsce przez klienta indywidualnego wyniosła w 2012 r. 68320 zł. Średnia cena auta używanego (sprowadzonego z zagranicy, jak również przerejestrowanego) jest wyraźnie niższa i wynosi $13132 \mathrm{z}^{3}$. Grupa aut używanych stanowi niewiele ponad $91 \%$ wszystkich samochodów zarejestrowanych przez prywatnych użytkowników. Pozwala to na określenie średniej ceny pojazdu w Polsce na około 18 tys. zł. Spadek wartości samochodu kształtuje się na poziomie 15\% rocznie. Tym samym w wartościach nominalnych roczny spadek wartości przeciętnego pojazdu to 2,7 tys. zł. Przyjmując roczny średni przebieg na poziomie 10 tys. km, każdy przejechany $1 \mathrm{~km}$ pomniejsza wartość samochodu prawie o $27 \mathrm{gr}$. Do pozostałych kosztów należy zaliczyć roczne ubezpieczenie komunikacyjne (OC i AC w wysokości około 1200 zł) oraz niezbędne naprawy samochodu (około $1600 \mathrm{zl}$ rocznie $)^{4}$. Obowiązkowy przegląd techniczny kosztuje przeciętnie $100 \mathrm{zl}$, a wymiana opon około 160 zł. Przy założeniu średniego przebiegu należy wymienić komplet opon po 5 latach użytkowania. Daje to roczny koszt w wysokości prawie

\footnotetext{
${ }^{3}$ http://www.samar.pl/_ /7/7.m/1140/7.t/3/7.3a/68145/Opel-Astra-IV---Stare--ale-jare---czyli-jakie-auta-kupuj\%C4\%85-Polacy.html (12.09.2013).

${ }^{4} \mathrm{http}: / / w w w . d a n e t e c h n i c z n e . c o m . p l /(25.09 .2013)$.
} 
400 zł. Pozostałe koszty związane z obsługą pojazdu zespół IGiPZ PAN oszacował na około 300 zł rocznie. Zsumowane koszty wraz z amortyzacją pojazdu wynoszą zatem 6,5 tys. zł., co daje 65 gr stałych kosztów eksploatacyjnych na każdy przejechany $1 \mathrm{~km}$ (przy założonym rocznym przebiegu).

Koszty zmienne eksploatacji pojazdów to koszty zużycia paliwa. Poziom spalania na $100 \mathrm{~km}$ wynika z szeregu czynników, do których można zaliczyć: rodzaj stosowanego paliwa, pojemność silnika oraz warunki ruchu (prędkość pojazdu, forma terenu oraz stan nawierzchni drogi). Zespół dr. Rosika dokonał kalkulacji kosztów zużycia paliwa, uwzględniając jego ceny (średnie dla 2012 r. ze względu na spójność z danymi dotyczącymi kosztów stałych) oraz strukturę parku samochodowego w zależności od pojemności silnika oraz wykorzystywanego paliwa. Najniższe spalanie występuje przy prędkości około $75 \mathrm{~km} / \mathrm{h}$, najwyższe zaś przy niskich prędkościach. Większemu zużyciu paliwa sprzyja również forma terenu o dużych różnicach wysokości względnych oraz zły stan nawierzchni (najniższe spalanie przy stanie nawierzchni o kategorii A, w tzw. klasyfikacji SOSN ${ }^{5}$ nawierzchnia o stanie dobrym; najwyższe spalanie dla kategorii D, w systemie SOSN nawierzchnia o stanie złym). Trudną kwestią jest właściwa ocena wzrostu zużycia paliwa dla prędkości poniżej $55 \mathrm{~km} / \mathrm{h}$ (prędkość pojazdów w terenie miejskim) i powyżej $90 \mathrm{~km} / \mathrm{h}$ (prędkość uzyskiwana na drogach szybkiego ruchu). Zakłada się, że w zakresie od $55 \mathrm{~km} / \mathrm{h}$ do $90 \mathrm{~km} / \mathrm{h}$ zmienność w zużyciu paliwa jest niewielka. Natomiast dla niższych, jak i dla wyższych prędkości zużycie paliwa rośnie. Koszt spalania jest różny dla podróży w mieście i w cyklu pozamiejskim. Zakładając średnią prędkość jazdy w dużym mieście na poziomie $30 \mathrm{~km} / \mathrm{h}$, zużycie paliwa wzrasta ponad $30 \%$ w stosunku do jazdy po „trasie”. Z kolei przy prędkości ok. $120 \mathrm{~km} / \mathrm{h}$ następuje również wzrost zużycia paliwa prawie o $23 \%{ }^{6}$. Do analizy włączono dane GUS dotyczące struktury parku samochodowego (samochody osobowe) w Polsce, w zależności od pojemności silnika oraz wykorzystywanego paliwa. Wśród małych pojazdów (do $1399 \mathrm{~cm}^{3}$ pojemności silnika) dominują samochody zasilane benzyną. W nieznacznie liczniejszej grupie pojazdów średnich (od 1400 do $1999 \mathrm{~cm}^{3}$ ), samochodów na benzynę jest więcej niż tych zasilanych gazem lub olejem napędowym. W grupie pojazdów dużych (od $\left.2000 \mathrm{~cm}^{3}\right)$ dominują samochody z silnikiem Diesla. Znaczna część pojazdów w Polsce ma ponad 10 lat (aż $72 \%$ ). Młodsze pojazdy przeważnie są droższe, po czym można wnioskować, że

${ }^{5}$ System Oceny Stanu Nawierzchni, http://www.gddkia.gov.pl/userfiles/articles/s/system-oceny-stanu-nawierzchni_6165//documents/aktualizacja-wytycznych-sosn-o-pomugiec.pdf (25.09.2013).

${ }^{6}$ Ponadto do czynników wpływających na zużycie paliwa należą: technika jazdy, sposób eksploatacji samochodu, ogumienie, stan zawieszenia, stan filtrów, jakość paliwa, wykorzystanie urządzeń elektrycznych oraz stan techniczny silnika. Większość powyższych czynników związana jest ze stanem technicznym pojazdu, który w dużej mierze wynika z wieku pojazdu. Dlatego też w analizie kosztów spalania paliwa wzięto pod uwagę pojazdy o zróżnicowanym wieku. 
ich użytkowników stać na dłuższe podróże samochodem i większą mobilność. Złożoność zjawiska znacznie utrudnia jednoznaczne wskazanie udziału pojazdów w ruchu w podziale na ich wiek ${ }^{7}$. W wyniku przeliczenia udziałów pojazdów według pojemności silnika oraz stosowanego paliwa, przez średnie ceny spalania na odcinku $100 \mathrm{~km}$ możliwe było określenie średniego kosztu spalania paliwa na $1 \mathrm{~km}$. Wynosi on około 44 gr dla jazdy z prędkością nie większą niż $30 \mathrm{~km} / \mathrm{h}$ i 36 gr dla większych prędkości.

Ostatnim włączonym do badania elementem kształtującym koszty podróży są opłaty za przejazd płatnymi odcinkami autostrad. Zgodnie z obowiązującym prawem wszystkie autostrady w Polsce docelowo będą płatne. Jednak na terenie województwa łódzkiego, do momentu przeprowadzania analizy płatny był jedynie odcinek autostrady A2 od zachodniej granicy województwa do węzła Łódź Północ. Odcinek ten stanowi część dłuższego odcinka Konin-Łódź Północ i zarządzany jest przez Generalną Dyrekcję Dróg Krajowych i Autostrad. Stawka opłaty za przejazd $1 \mathrm{~km}$ autostrady dla pojazdów samochodowych o dopuszczalnej masie całkowitej nieprzekraczającej 3,5 t wynosi 10 gr $^{8}$. Oddany w czerwcu 2012 r. fragment autostrady między węzłem Łódź Północ a Warszawą pozostaje bezpłatny do 2014 r. Opłaty za przejazd autostradą A1 pobierane są jedynie na odcinku Rusocin-Nowa Wieś za Grudziądzem. Wybór autostrady, zamiast równoległej drogi krajowej, niesie za sobą poza oszczędnością czasu również korzyści związane z trzecim elementem uogólnionego kosztu podróży, czyli wysiłkiem (wygodą) podróży. Dotyczy on nie tylko komfortu podróży związanego z możliwością jazdy ze stałą prędkością bez zmiany jej kierunku na autostradzie, ale również zmęczenia (zdecydowanie niższego na autostradzie) oraz stresu wynikającego z bezpieczeństwa jazdy. Prawdopodobieństwo wypadków na autostradach i drogach ekspresowych jest znacznie niższe niż na pozostałych drogach krajowych ${ }^{9}$.

Reasumując, całkowity koszt podróży jednej osoby samochodowym transportem indywidualnym wynosi:

- na wszystkich drogach z wyłączeniem płatnych autostrad, przy prędkości nieprzekraczającej $30 \mathrm{~km} / \mathrm{h}-1,09 \mathrm{z} / \mathrm{km}$;

${ }^{7}$ Do analizy porównawczej wybrano nową Skodę oraz starsze modele Forda i Opla. Testy spalania dla Skody Octavia II (samochód nowszy; 2004-2012), Forda Focusa I (samochód starszy; 1998-2005) oraz Opla Astry F (samochód najstarszy; 1991-2005) zostały wykonane na podstawie strony internetowej (www.autocentrum.pl). Obliczenia sporządzono z wykorzystaniem średnich cen detalicznych benzyny (Pb95), oleju napędowego oraz gazu (LPG) dla całego kraju z 25 lipca 2012 r. (odpowiednio: benzyna - 5,64 zł; olej napędowy - 5,56 zł; gaz LPG - 2,75 zł; ceny za litr).

${ }^{8}$ Ministerstwo Infrastruktury ustaliło stawki opłaty za przejazd autostradami w rozporządzeniu Ministerstwa Infrastruktury z 14 czerwca 2011 r. w sprawie stawek opłat za przejazd autostradą. Na jego podstawie, na odcinkach autostrad zarządzanych przez Generalną Dyrekcję Dróg Krajowych i Autostrad, stawka opłaty za przejazd $1 \mathrm{~km}$ autostrady dla pojazdów samochodowych o dopuszczalnej masie całkowitej nieprzekraczającej 3,5 t wynosi $10 \mathrm{gr}$.

${ }^{9} \mathrm{http}: / /$ www.eurorap.pl/index.php?option=com_content\&view=article\&id=99 (3.09.2013). 
- na wszystkich drogach z wyłączeniem płatnych autostrad, przy prędkości powyżej $30 \mathrm{~km} / \mathrm{h}-1,01 \mathrm{zl} / \mathrm{km}$;

- na płatnych autostradach ${ }^{10}-1,11 \mathrm{z} / / \mathrm{km}$.

Po przyjęciu ustalonych stawek, teoretyczny koszt przejazdu pomiędzy każdą $\mathrm{z}$ par miast $\mathrm{w}$ województwie łódzkim ustalono, postępując zgodnie $\mathrm{z}$ algorytmem przyjętym na potrzeby obliczeń czasu. $Z$ tą tylko różnicą, że długość odpowiednich odcinków drogi (pozwalających na różnicowanie stawek) o możliwie najkrótszym czasie jazdy mnożono przez odpowiednie stawki, a nie zamieniano na minuty.

W ujęciu topologicznym analizę kosztów dojazdu do miast województwa łódzkiego wykonano w oparciu o konstrukcję izodapan przyjmujących wartości wielokrotności 20 zł od 0 do 220 (rycina 4.4). Ogólnie należy stwierdzić, że dostępność miast województwa w ujęciu odległości ekonomicznych nie różni się znacząco od tej określonej przez odległości czasowe. Wynika to przede wszystkim z nieznacznych różnic pomiędzy poszczególnymi stawkami oraz niskim udziałem odcinków dróg o prędkości ograniczonej do $30 \mathrm{~km} / \mathrm{h}$ i autostrad objętych opłatami. Najpowszechniej występująca odległość ekonomiczna pomiędzy miastami województwa łódzkiego wynosi od 40,1 do $60 \mathrm{zł}$. Jest to również zasięg charakteryzujący się jednym z największych zróżnicowań liczebności miast w ujęciu bilateralnym (od 3 połączeń dla Radomska i Wieruszowa do 13 dla Zelowa; odchylenie standardowe wynosi 2,58). Wyraźnie najbardziej zróżnicowaną grupą są połączenia w zakresie 20,1-40 zł (odchylenie standardowe wynosi 3,35). Liczba relacji spada wraz ze wzrostem ich kosztu, aby osiągnąć jedynie cztery relacje droższe niż 200 zł. Dotyczą one połączeń pomiędzy Skierniewicami, Kutnem, Wieruszowem i Pajęcznem.

Najwyższym poziomem dostępności w ujęciu ekonomicznym (w zakresie izodapany 100 zł) charakteryzują się Łódź, Pabianice, Konstantynów Łódzki oraz Rzgów. Każde z miast w zakresie tej kwoty dostępne jest z ponad 40 innych ośrodków. Wśród dziesięciu najlepiej dostępnych pod tym względem ośrodków znalazły się również Piotrków Trybunalski, Bełchatów, Aleksandrów Łódzki, Łask, Konstantynów Łódzki, Koluszki, Tuszyn oraz Szadek. Podobnie jak w ujęciu czasowym, najbardziej peryferyjnymi ośrodkami są Wieruszów oraz Drzewica. W izodapanie 100 zł dostępne są odpowiednio jedynie z 14 i 18 miast województwa.

Zastosowanie odległości ekonomicznych do określenia dostępności miast województwa łódzkiego uwidacznia się w zmianie przebiegu linii określających jednostki o podobnym jej poziomie. W porównaniu do przedstawionych wcześniej izochron, mają one układ bardziej koncentryczny względem każdego $\mathrm{z}$ analizowanych ośrodków. Nie występują tak wyraźne anomalia w ich przebiegu. Należy oczywiście zwrócić uwagę na mniejszą liczbę skonstruowanych izodapan niż linii łączących punkty o tej samej dostępności czasowej. Obejmują one jednocześnie zakres o większej rozpiętości, co przyczynia się w pewnym stop-

\footnotetext{
${ }^{10}$ Minimalna prędkość poruszania się po autostradzie wynosi $40 \mathrm{~km} / \mathrm{h}$.
} 


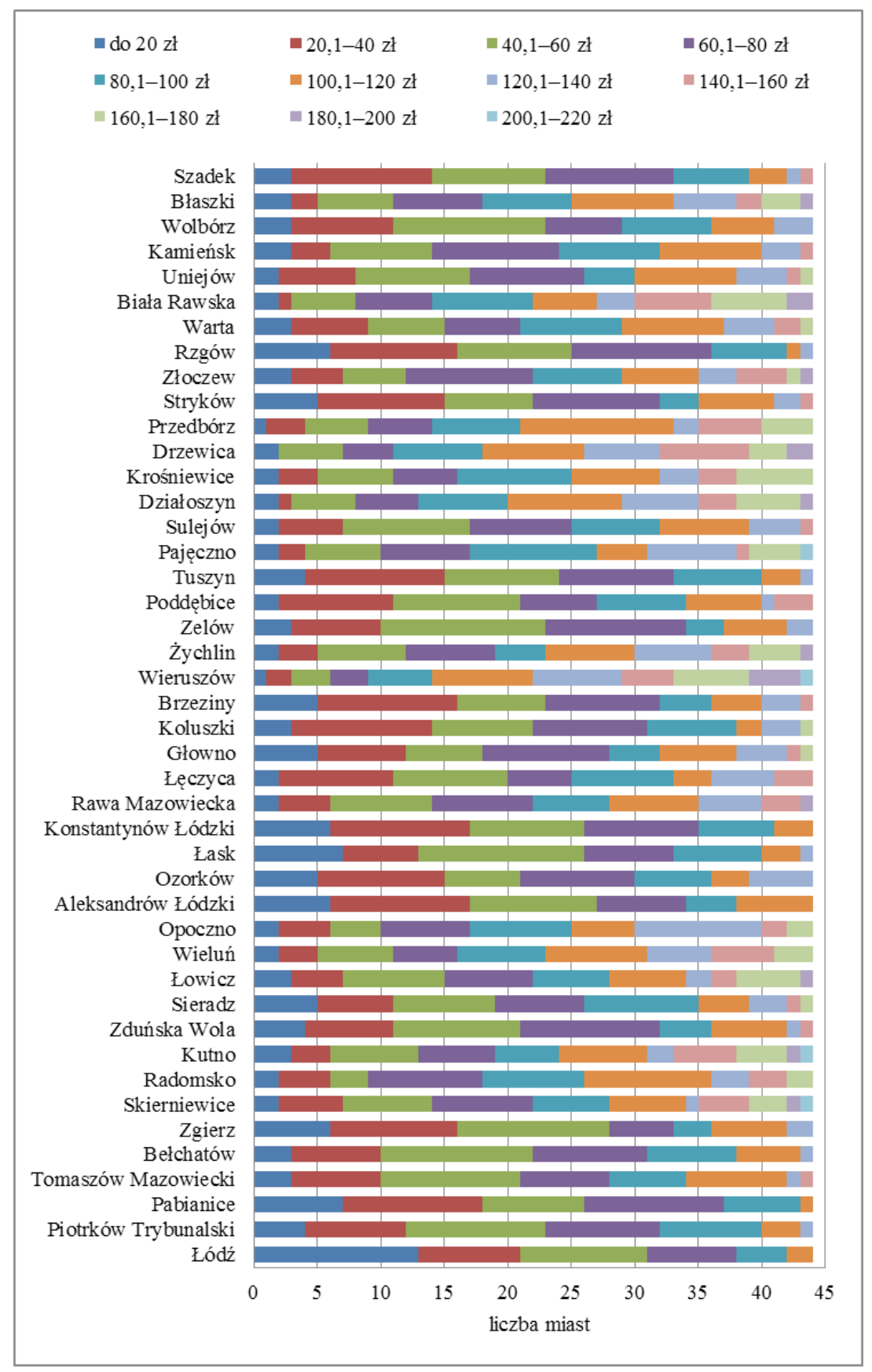

Rycina 4.4. Liczba ośrodków w izodapanach dojazdu samochodem osobowym do miast województwa łódzkiego

Źródło: opracowanie własne 
niu do „ukrywania” ewentualnych zniekształceń wynikających z przyjęcia jednostek pieniężnych.

Główną przyczyną większej regularności przebiegu izodapan jest znacznie mniejsze zróżnicowanie wag dla poszczególnych odcinków dróg w ujęciu kosztowym. Maksymalny stosunek stawek to jedynie 0,91 . Podczas gdy przy analizach czasowych stosunek ten może wynosić np. 0,21 (przy przyjęciu występowania na danej drodze odcinków autostrady z ograniczeniem prędkości do $140 \mathrm{~km} / \mathrm{h}$ i odcinka, gdzie prędkość ograniczono do $30 \mathrm{~km} / \mathrm{h}$ ).

Szczególnie powyższe zmiany uwidaczniają się w przypadku najgorzej dostępnego pod względem ekonomicznym Wieruszowa. Przebieg izodapan ma charakter znacznie bardziej koncentryczny bez tak wyraźnych anomalii jak w przy-

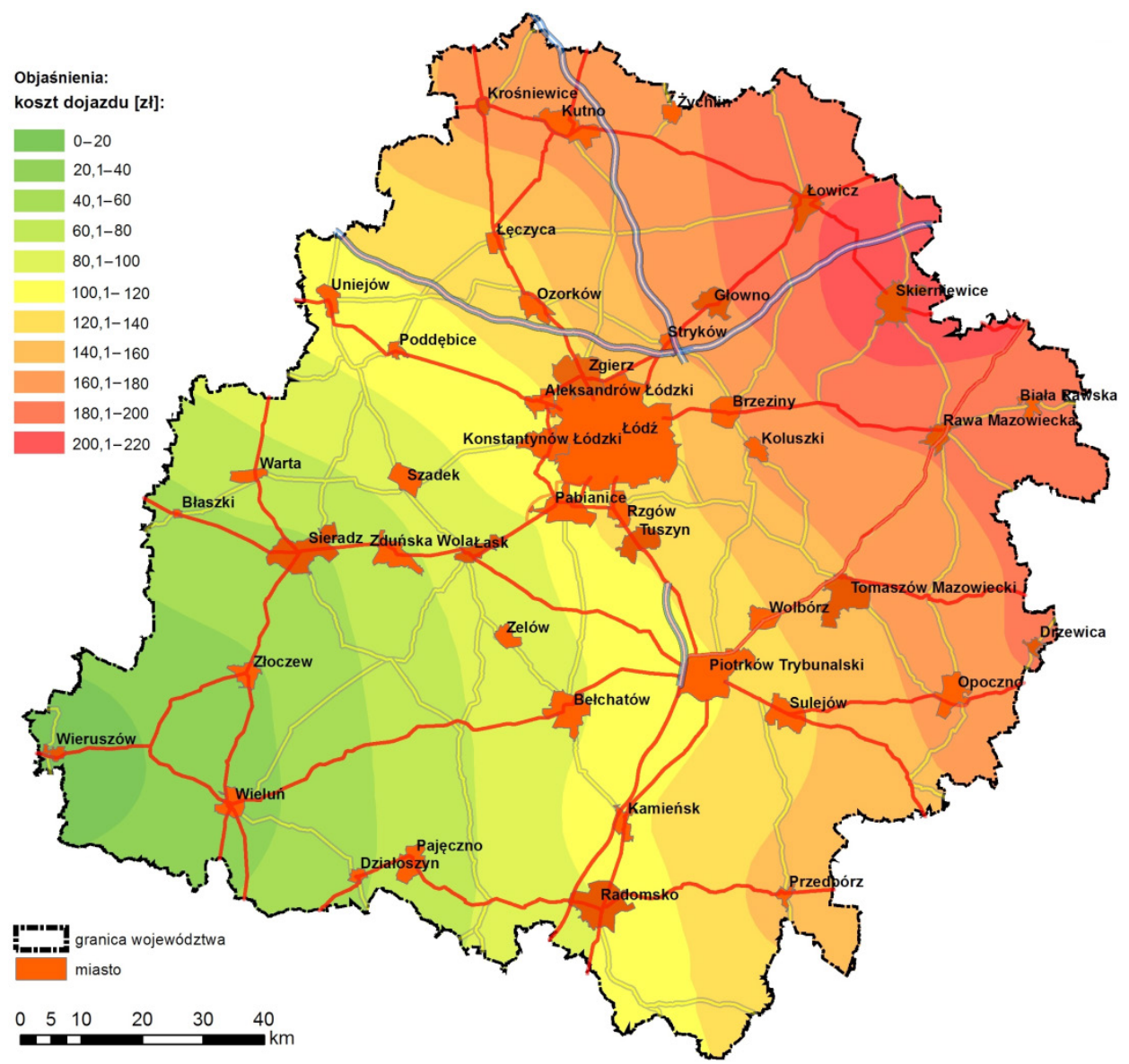

Rycina 4.5. Koszt dojazdu do Wieruszowa przy założeniu poruszenia się samochodem osobowym z maksymalną dozwoloną prędkością

Źródło: opracowanie własne 
padku czasu dojazdu z Rawy Mazowieckiej (rycina 4.5). Występują oczywiście pewne zniekształcenia związane z przebiegiem m.in. drogi ekspresowej S8. Niemniej jednak liczba jednostek $\mathrm{w}$ poszczególnych izoliniach jest wyraźnie bardziej zrównoważona niżeli w przypadku analizy teoretycznych czasów dojazdów. Układ izodapan dla najlepiej dostępnej pod względem kosztów Łodzi nieznacznie jedynie zmienia obraz jej dostępności z pozostałych ośrodków województwa (rycina 4.6). Rozchodzące się promieńskie drogi są bardzo mało zróżnicowane pod względem kryteriów wpływających na koszty podróży (zaburzeniem jest jedynie płatny odcinek autostrady A2), co powoduje że przyrost kosztu podróży jest niemalże wprost proporcjonalny do wzrostu odległości od miasta.

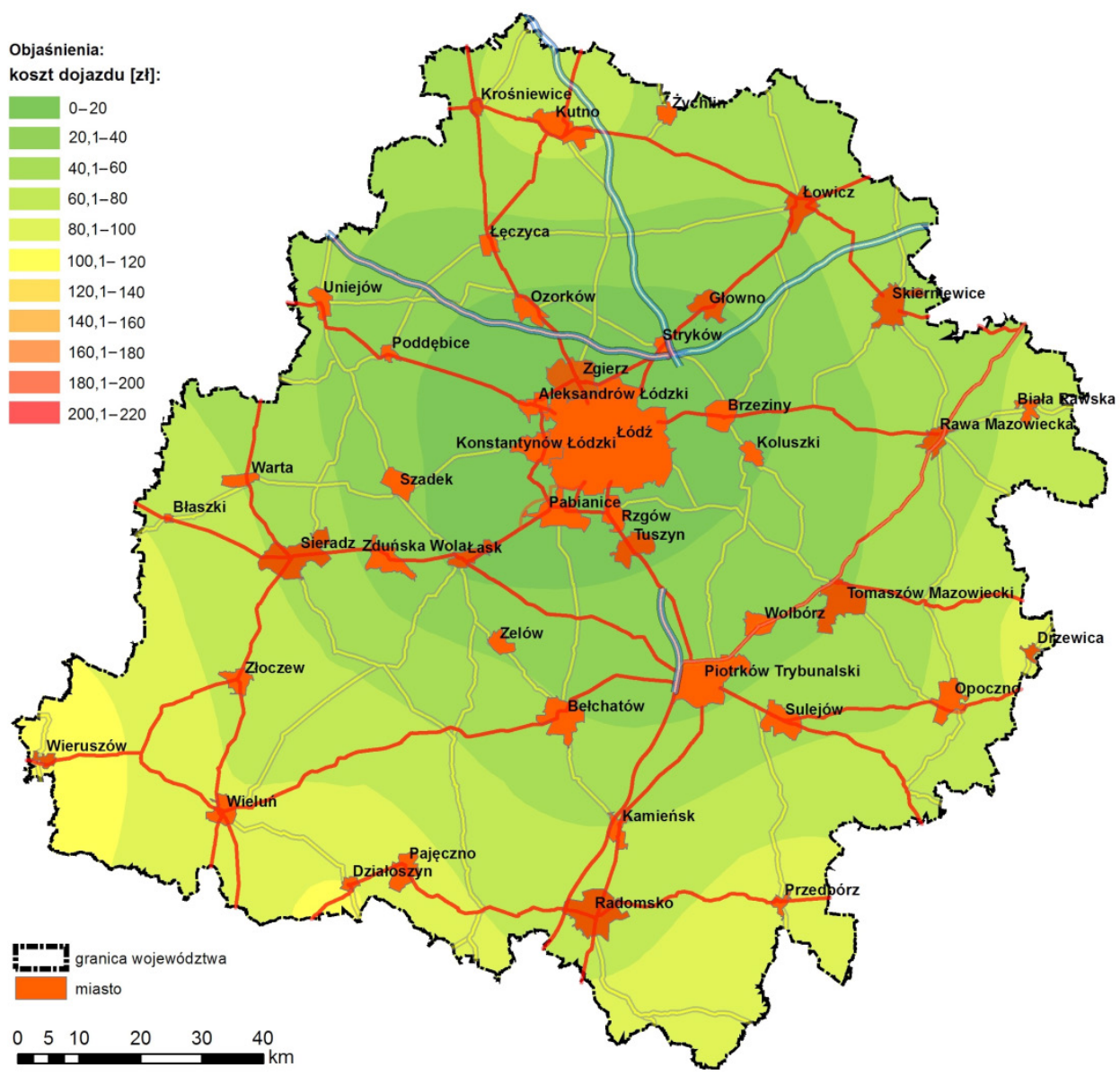

Rycina 4.6. Koszt dojazdu do Łodzi przy założeniu poruszenia się samochodem osobowym z maksymalną dozwoloną prędkością

Źródło: opracowanie własne 


\subsection{Dostępność transportowa $w$ ujęciu modelowym}

Przedstawione powyżej analizy dostępności miast regionu zakładały całkowicie teoretyczne odległości czasowe i ekonomiczne pomiędzy ośrodkami. Takie rozważania, choć bardzo wyraźnie ukazują zróżnicowanie poziomu dostępności każdego z miast i pozwalają na szereg powiązanych analiz, mają jedno podstawowe założenie wstępne - odrzucają cały szereg zmiennych urealniających uzyskane wyniki. Podejście teoretyczne powoduje, że są one w znaczniej mierze podyktowane poziomem zainwestowania infrastrukturalnego $\mathrm{w}$ zakresie transportu i prawodawstwa dotyczącego organizacji ruchu drogowego, które z kolei w wielu przypadkach jest zdeterminowane samym stanem infrastruktury. Pomijane są jednak czynniki wynikające z warunków jazdy, a związane z szeroko pojętymi uwarunkowaniami przyrodniczymi oraz oddziaływaniem innych uczestników ruchu. Jedną ze ścieżek rozwiązania tego problemu jest wprowadzenie do analiz modelowania. Tego rodzaju analizy prędkości ruchu samochodowego, umożliwiające prawie wierne odtworzenie warunków na drodze, są jednym z najtrudniejszych zagadnień w inżynierii drogowej. Można założyć, że w różnych miejscach sieci transportowej nigdy nie występują takie same okoliczności, możliwe do matematycznego skwantyfikowania. To uniemożliwia ustalenie wzoru na prędkość chwilową, a tym bardziej na średnią prędkość jazdy lub podróży. Zakładając teoretyczne współwystępowanie identycznych parametrów drogi, stanu pogody, charakterystyki samochodu, a ponadto prędkości, natężenia i struktury ruchu innych użytkowników drogi, niemożliwe jest opracowanie niezawodnego narzędzia badawczego. Nie zostaje bowiem włączony do analizy czynnik ludzki. Finalne decyzje dotyczące zachowań na drodze pozostają zawsze w gestii kierowcy o specyficznych cechach psychicznych, doświadczeniu, stanie emocjonalnym. Szczegółowe badania wskazują nawet, że decyzja o wyborze prędkości i stylu jazdy jest uzależniona od celu podróży. Ta sama prędkość chwilowa lub podróży może zatem wynikać z bardzo różnych przyczyn. Dlatego też w świetle tak szerokiej gamy uwarunkowań, wszelkie ustalenia modeli prędkości mają charakter probabilistyczny i szacunkowy. Najwierniej rzeczywistość odzwierciedlają pomiary ruchu, które pozwalają na kalibrację modeli, uwzględniających podstawowe czynniki, wpływające na różne rodzaje prędkości (Rosik, Śleszyński 2009). Skonstruowano wiele funkcji dopasowujących różne zmienne. Nie daje to jednak możliwości prowadzenia tego rodzaju badań w systemie ciągłym dla wszystkich odcinków dróg. Dlatego też modele prędkości ruchu powinny być budowane pod kątem charakterystyki konkretnego obszaru. Brak uniwersalności co do zakresu przestrzennego i czasowego badania jest największą wadą tego rodzaju rozwiązań. Dynamiczny rozwój systemów transportowych sprawia, że budowa modeli opartych o techniczne własności dróg charakteryzuje się coraz mniejszą dokładnością. Z drugiej zaś strony dynamiczny rozwój społeczno-gospodarczy wymusza 
coraz większą precyzję w analizach procesów regionalnych, wśród których dominującą rolę odgrywa dostępność. Określenie liczby mieszkańców będących w zasięgu wyznaczonych izochron mówiących o dostępności czasowej jest jednym z podstawowych narzędzi ewaluacji systemów transportowych. Jest to szczególnie ważne dla obszarów $\mathrm{z}$ dominującą $\mathrm{w}$ przemieszczaniu rolą dojazdów do pracy.

Biorąc pod uwagę powyższe uwarunkowania, w trakcie analiz realizowanych przez Instytut Geografii i Przestrzennego Zagospodarowania PAN opracowano modele czasowej dostępności przestrzennej, które oceniały efektywności złożonych systemów społeczno-gospodarczych w skali regionalnej, krajowej, ale również w ujęciu międzynarodowym. W ten sposób uzyskano metodę umożliwiającą wskazanie miejsc w obszarze sieci drogowej, w których utrudnienia w ruchu mogą pojawić się z dużym prawdopodobieństwem.

Na potrzeby niniejszej pracy wykorzystano model opracowany przez Rosika i Śleszyńskiego (2009). W metodzie tej średnią prędkość jazdy samochodem osobowym na odcinku drogi zdefiniowano jako iloczyn trzech współczynników: wpływu zaludnienia w otoczeniu odcinka drogi, wpływu ukształtowania powierzchni terenu oraz wpływu natężenia ruchu. Model ten poddany został pewnej przebudowie i optymalizacji m.in. na potrzeby analizy Dostępności ladowej przestrzeni Polski w wymiarze europejskim (Rosik 2012) czy Oceny wptywu projektów drogowych realizowanych $w$ ramach regionalnych programów operacyjnych na zwiększenie dostępności transportowej województw (Rosik i in. 2012). Zastąpiono m.in. stosowaną wcześniej funkcję eksponencjalną funkcją logitową, której zaletą jest jej s-kształtny charakter. Redukcja prędkości ma charakter ciągły w zależności od liczby ludności w buforze odcinka, odsetka obszaru zabudowanego lub ukształtowania powierzchni terenu. Przy niskich wartościach zmiennych redukujących prędkość, funkcja logitowa opada, skutkując niewielkimi spadkami prędkości. Przy większych wartościach zmiennych redukujących prędkość, redukcja prędkości jest już znacznie wyższa. Przy bardzo wysokich wartościach zmiennych warunkujących prędkość, jest ona coraz niższa, choć spadek nie jest już tak duży (granicą funkcji jest prędkość minimalna, bliska zerowej, dla zmiennych warunkujących prędkość dążących do nieskończoności) (Rosik 2012). Niemniej jednak zdecydowano się na pozostanie przy wcześniejszym kształcie modelu ze względu na dwie kwestie. Po pierwsze zakłada on badanie liczby ludności w okolicach drogi w buforze $1 \mathrm{~km}$, a nie $5 \mathrm{~km}$, do czego skalibrowane są późniejsze wersje. W opinii autora tak szeroki bufor przy analizach w zakresie województwa wydaje się zbyt duży. Powodowałby częste sytuacje, gdy bufor jednej drogi obejmuje znaczną część miejsc zamieszkania ludności położonych nad inną drogą, do której w jego zakresie nie ma istniejącego połączenia. Ponadto dla liczby ludności zamieszkałej w buforze odcinka, dla różnych kategorii drogi przyjęto pewne poziomy minimalnych prędkości zgodnie z wynikami otrzymanymi np. w systemie Community Traffic, stosowanym przez firmę NaviEkspert. System ten bazuje oczywiście na danych o aktualnym ruchu pojazdów, natomiast nie wskazu- 
je on konkretnych punktów, w których konkretny pojazd porusza się z określoną prędkością. Pokazuje odcinek drogi, dla którego dzięki szacunkom na podstawie danych aktualnych i archiwalnych określana jest średnia prędkość poruszania się pojazdów. Autor oparł badanie na wcześniejszym modelu również w celu uniknięcia bazowania na takowych szacunkach. Ponadto w dalszej części rozdziału zostanie przedstawiona autorska metoda analizy ruchu pojazdów, bazująca na danych o ruchu pojazdów przekazywanych w czasie rzeczywistym.

Poprzez wykorzystanie formuły iloczynu wobec trzech branych pod uwagę zmiennych, założono ich wzajemną niezależność ${ }^{11}$. Obliczona średnia prędkość jazdy jest prędkością, którą można uznawać jako prędkość miarodajną pomniejszoną o prędkość nadkodeksową, tj. taką, która wynika z nieprzestrzegania przepisów o ruchu drogowym, wynikających z systemowych ograniczeń prędkości. Na potrzeby badania do analizy włączono drogi krajowe (o ograniczonej dostępności i ogólnodostępne) oraz wojewódzkie, dzieląc je na 260 odcinków badawczych. Podział drogi na odcinki miał miejsce w punkach (skrzyżowaniach), gdzie możliwe było wybranie drogi alternatywnej. W przypadku gdy przez miasto przebiegała droga niekrzyżująca się z żadną inną na jego obszarze, dokonywano podziału odcinka w granicach miasta na dwie równe części. Pozwalało to na późniejszą analizę czasu i kosztu dojazdu do danego miasta. Jeśli na terenie miasta występowało kilka skrzyżowań, to czasy i koszty dojazdu określano do pierwszego skrzyżowania w granicach miasta, na drodze prowadzącej do niego $\mathrm{z}$ danego kierunku. Każdy z odcinków przyporządkowano do odpowiadającej mu kategorii drogi ${ }^{12}$, co pozwoliło w dalszej analizie na przyporządkowanie odpowiednich parametrów modelu (Rosik, Śleszyński 2009), różnicujących siłę wpływu poszczególnych trzech zmiennych na poszczególne kategorie dróg.

Pierwsza zmienna obrazuje wpływ zaludnienia wokół drogi. Czynnik ludnościowy w przedstawionym modelu jest przesłanką generującą utrudnienia lokalne. Współczynnik wpływu zaludnienia $\left(f_{l}\right)$ w otoczeniu drogi przedstawiono we wzorze:

gdzie:

$$
f_{l}=\frac{1}{\frac{p_{Z}\left(\alpha_{1}+\left(1-\alpha_{1}\right) \exp \left(\beta_{1} L\right)\right.}{v_{Z}}+\frac{1-p_{Z}}{v_{k}}},
$$

${ }^{11}$ Założenie to może być korygowane w zależności od obszaru badania, ponieważ wraz z udziałem liczby czynników utrudniających płynność ruchu i jego prędkość, nie działają one liniowo, ale odwrotnie wykładniczo.

${ }^{12}$ Autostrada (A), droga ekspresowa dwujezdniowa z dwoma pasami na każdej jezdni (E2), droga ekspresowa jednojezdniowa (E1), droga krajowa dwujezdniowa z dwoma psami na każdej jezdni (K2), droga wojewódzka dwujezdniowa ulepszona z dwoma psami na każdej jezdni (W2u), droga wojewódzka dwujezdniowa z dwoma psami na każdej jezdni (W2), droga krajowa jednojezdniowa ulepszona (K1), droga wojewódzka jednojezdniowa ulepszona (W1u), droga wojewódzka jednojezdniowa (W1z). 
$L$ - liczba ludności w promieniu $1 \mathrm{~km}$ od drogi (w tys.),

$v_{k}$ - prędkość kodeksowa (na obszarze niezabudowanym),

$v_{z}$ - prędkość maksymalna na obszarze zabudowanym,

$p_{z}$ - udział terenów zabudowanych w łącznej długości odcinka,

$\alpha_{1}, \beta_{1}$ - parametry modelu.

Tabela 4.1. Parametry modelu - współczynnik wpływu zaludnienia

\begin{tabular}{|l|l|l|l|l|l|l|l|l|l|}
\hline $\begin{array}{c}\text { Parame- } \\
\text { try }\end{array}$ & \multicolumn{1}{|c|}{ A } & \multicolumn{1}{|c|}{ E2 } & \multicolumn{1}{|c|}{ E1 } & \multicolumn{1}{|c|}{ K2 } & W2u & W2 & K1 & W1u & W1z \\
\hline$\alpha_{1}$ & 0,9 & 0,9 & 0,9 & 0,8 & 0,6 & 0,6 & 0,6 & 0,6 & 0,6 \\
\hline$\beta_{1}$ & 0,0004 & 0,0004 & 0,0004 & 0,0006 & 0,0008 & 0,0010 & 0,0010 & 0,0010 & 0,0010 \\
\hline
\end{tabular}

Źródło: opracowanie własne na podstawie Rosik, Śleszyński (2009).

Liczbę ludności w buforze $1 \mathrm{~km}$ wokół dróg określono na podstawie warstwy - Budynki mieszkalne, zawartej w Bazie Danych Obiektów Terenowych (2010). Przyjmując metodologię GUS ${ }^{13}$, w jednym budynku zamieszkanym ${ }^{14}$ W mieście znajduje się średnio 4,13 mieszkania, zaś na terenach wiejskich 1,18 mieszkania. W mieście na jedno mieszkanie przypada średnio 2,7 osoby, co wskazuje, że w całym budynku jest ich średnio 11,15. Na terenach wiejskich w jednym mieszkaniu średnio zamieszkuje 3,8 osoby, dlatego też w budynku jest ich średnio 4,484. Po zliczeniu budynków w buforach każdej z dróg, w podziale na zlokalizowane w mieście i poza nim, mnożono ich ilość przez średnią liczbę mieszkańców.

Niezbędne do analizy prędkości ustalono zgodnie z przepisami ruchu drogowego. Według przepisów, poza obszarem zabudowanym prędkość dopuszczalna wynosi w przypadku samochodu osobowego, motocyklu lub samochodu ciężarowego o dopuszczalnej masie całkowitej nieprzekraczającej 3,5 t (Prawo drogowe, rozdział 3 , oddział 3 , art. 20): na autostradzie $-140 \mathrm{~km} / \mathrm{h}$, na drodze ekspresowej dwujezdniowej - $120 \mathrm{~km} / \mathrm{h}$, na drodze ekspresowej jednojezdniowej oraz na drodze dwujezdniowej co najmniej o dwóch pasach przeznaczonych dla każdego kierunku ruchu $-100 \mathrm{~km} / \mathrm{h}$, na pozostałych drogach $-90 \mathrm{~km} / \mathrm{h}$. Ponadto na obszarze zabudowanym pojazdy nie powinny przekraczać $50 \mathrm{~km} / \mathrm{h}$ w godzinach $5.00-23.00$ i $60 \mathrm{~km} / \mathrm{h}$ w godzinach 23.00-5.00 (badanie wykonano dla podróży w czasie dnia).

${ }^{13}$ Zamieszkane budynki, http://www.stat.gov.pl/cps/rde/xbcr/gus/L_zamieszk_budynki_ nsp_2011.pdf (13.09.2013).

${ }^{14}$ Budynek przeznaczony na cele mieszkalne, zajęty przez lokale mieszkalne w całości, lub budynek zajęty przez lokale mieszkalne co najmniej w połowie, a w pozostałej części przez inne pomieszczenia, z wyjątkiem budynku mieszkalno-inwentarskiego lub mieszkalno-gospodarskiego (http://www.stat.gov.pl/gus/definicje_PLK_HTML.htm?id=POJ-3312.htm, 13.09.2013). 
Ostatnim niezbędnym elementem było określenie udziału terenów zabudowanych w łącznej długości odcinka badawczego. Obliczenia wykonano na podstawie danych udostępnionych przez Generalną Dyrekcję Dróg Krajowych i Autostrad oddział w Łodzi, w postaci kwerendy z Banku Danych Drogowych oraz zestawienia tabelarycznego udostępnionego przez Zarząd Dróg Wojewódzkich w Łodzi, zawierającego wykaz obszarów zabudowanych wraz z pikietażem.

Przyjęto, że liczba ludności zamieszkałej w promieniu $1 \mathrm{~km}$ od drogi jest wyznacznikiem miejskiego charakteru odcinka badawczego sieci. Wysoka liczba mieszkańców zwiększa prawdopodobieństwo wystąpienia utrudnień w ruchu. Sygnalizacja świetlna, ruch pieszych oraz rowerzystów w połączeniu z przydrożną zabudową o wysokiej intensywności mogą stanowić silną barierę dla sprawnego przemieszczania się pojazdów. Duża liczba zjazdów z dróg na prywatne posesje, osiedla mieszkaniowe czy wyjazdy z parkingów wysoce uprawdopodabniają większą liczbę pojazdów włączających się do ruchu oraz parkujących. Wszystkie wspomniane elementy występują przede wszystkim na terenach zabudowanych. Wybór prędkości przemieszczania się samochodu dokonywany przez kierowcę podczas jazdy przez małe i średnie miejscowości jest determinowany m.in. intensywnością zabudowy, rodzajem pobocza i długością przejazdu przez ośrodek. W odniesieniu do ulic jest to również intensywność zabudowy, a ponadto maksymalna dopuszczalna prędkość na danym odcinku oraz typ przekroju poprzecznego drogi (Brzeziński 1999). W modelu przyjęto, że średnia prędkość jazdy nie jest uzależniona od poziomu zaludnienia wokół drogi poza terenami zabudowanymi. Ponadto wpływ utrudnień w ruchu wynikający z przejazdu przez obszar o wysokim udziale zabudowy jest odwrotnie proporcjonalny do kategorii drogi, która przez niego prowadzi. Dlatego też w przypadku autostrad i dróg ekspresowych przebiegających przez miasta, wszelkie utrudnienia w płynności ruchu mają znaczenie marginalne. Wynika to m.in. z braku skrzyżowań lub ich bezkolizyjnego charakteru oraz zabudowy, która w żaden sposób nie jest z nimi powiązana. Dla dróg o ograniczonej dostępności na odcinkach przechodzących przez miasta, najważniejszym elementem warunkującym średnią prędkość jest natężenie ruchu. Współczynnik wpływu zaludnienia w ekwidystancie $1 \mathrm{~km}$ wokół drogi może przyjmować wartości od zera do maksymalnej dozwolonej przez kodeks drogowy prędkości na analizowanym odcinku badawczym. Najwyższe wartości współczynnika, równe maksymalnej dozwolonej prędkości, występują na odcinkach poza obszarami zabudowanymi. Parametry modelu skalibrowano w taki sposób, aby spadki prędkości $\mathrm{w}$ terenie zabudowanym $\mathrm{w}$ odniesieniu do maksymalnych dozwolonych były niższe dla dróg o wyższych klasach. Założono, że wzrost kategorii drogi pociąga za sobą podwyższanie przez kierowców prędkości jazdy. Ponadto sami zarządcy dróg wyższych kategorii podnoszą maksymalne dozwolone prędkości na terenach zabudowanych ponad wyjściowe $50 \mathrm{~km} / \mathrm{h}$. 
W modelu, na drogach dwupasmowych i dwukierunkowych, założono na obszarze zabudowanym prędkość maksymalną równą $70 \mathrm{~km} / \mathrm{h}$ dla dróg krajowych oraz 50-60 dla dróg wojewódzkich. Prędkość średnia jest obniżana wraz ze wzrostem zaludnienia w otoczeniu odcinka drogi.

Kolejnym czynnikiem wpływającym na ograniczenia prędkości i uwzględnionym w modelu jest ukształtowanie powierzchni. Jej współczynnik $\left(f_{u}\right)$ przyjmuje wartości w przedziałach od 0 do 1 i wyrażony jest wzorem:

$$
f_{u}=\frac{1}{\alpha_{u}+\left(1-\alpha_{u}\right) \exp \left(\beta_{u} U\right)}
$$

gdzie:

$U$ - ukształtowanie powierzchni terenu (odchylenie standardowe wysokości względnych), $\alpha_{u}, \beta_{u}$ - parametry modelu.

Tabela 4.2. Parametry modelu - współczynnik wpływu ukształtowania powierzchni terenu

\begin{tabular}{|l|l|l|l|l|l|l|l|l|l|}
\hline $\begin{array}{c}\text { Parame- } \\
\text { try }\end{array}$ & \multicolumn{1}{|c|}{ A } & E2 & E1 & K2 & W2u & W2 & K1 & W1u & W1z \\
\hline$\alpha_{u}$ & 0,9 & 0,9 & 0,9 & 0,9 & 0,9 & 0,9 & 0,9 & 0,9 & 0,9 \\
\hline$\beta_{u}$ & 0,006 & 0,006 & 0,006 & 0,009 & 0,010 & 0,012 & 0,014 & 0,016 & 0,020 \\
\hline
\end{tabular}

Źródło: opracowanie własne na podstawie Rosik, Śleszyński (2009).

Pomiar wysokości wykonano na podstawie map Google Earth, dokonując odczytu wysokości dla każdego odcinka badawczego w osi jezdni, przyjmując interwał 100 m odległości. W przypadku gdy odcinek badawczy był krótszy niż $100 \mathrm{~m}$, dzielono go na dwie równe części i pomiar wykonywano w punkcie środkowym oraz początkowym i końcowym.

Trzecim współczynnikiem, decydującym w zastosowanym modelu o prędkości średniej, jest natężenie ruchu. Relacje między natężeniem ruchu, prędkością oraz tzw. gęstością ruchu (liczbą pojazdów na długości drogi) są tematem szeroko opisywanym w literaturze przedmiotu. Dla przykładu w USA opracowano serię publikacji poświęconych obliczaniu przepustowości pod nazwą Highway Capacity Manual (HCM) ${ }^{15}$. W wypracowanych tam modelach określa się tzw. obliczeniowe natężenie ruchu. Bierze ono pod uwagę natężenie ogółem w godzinach szczytu komunikacyjnego, wskaźnik nierównomierności ruchu w godzinach szczytu komunikacyjnego, wpływ pochylenia podłużnego drogi, wpływ pojazdów ciężkich w ruchu oraz liczbę pasów w jednym

${ }^{15}$ Obejmuje ona pięć wydań a ostatnie ukazało się w 2010 r. (http://www.trb.org/Main/Blurbs/ Highway_Capacity_Manual_2010_HCM2010_164718.aspx, 13.09.2013). Na ich podstawie również w Polsce podjęto badania na poligonach badawczych (Gaca i in.2008). 
kierunku (w przypadku dróg wielopasmowych). W Polsce badania związane z natężeniem ruchu $\mathrm{w}$ godzinach szczytu na skalę ogólnokrajową nie są prowadzone. Źródłem danych dla całego kraju jest jedynie Generalny Pomiar Ruchu, którego ostatnia edycja miała miejsce w 2010 r. Pomiar przeprowadzony jest na zamiejskich drogach krajowych i wojewódzkich, i obejmuje średni dobowy ruch w roku, średni dzienny ruch w dni robocze, dzienny ruch w niedzielę i święta oraz średni ruch nocny. Dlatego też przyjęto, że natężenie ruchu w godzinach szczytu kształtuje się na poziomie 10\% natężenia dobowego. Oddziaływanie pochylenia podłużnego drogi określono osobnym wzorem. Wpływ pojazdów ciężkich w ruchu oszacowano, postępując zgodnie z algorytmem zawartym w HCM. Za pomocą funkcji potęgowej przedstawiono czynnik liczebności pasów w jednym kierunku, zaś w przypadku dróg z pojedynczymi pasami w każdym kierunku wprowadzono zróżnicowanie parametrów modelu. Współczynnik natężenia ruchu wyrażono wzorem:

$$
f_{n}=\frac{1}{\alpha_{n}+\left(1-a_{n}\right) \exp \left(\beta_{n} P^{-2}\left(1+p_{c}\left(e_{c}-1\right) N\right)\right.}
$$

gdzie:

$N$ - natężenie ruchu ogółem w poj./dobę,

$P$ - liczba pasów w danym kierunku,

$e_{c}$-współczynnik przeliczeniowy samochodów ciężarowych na pojazdy umowne, $p_{c}$ - udział w ruchu samochodów ciężarowych,

$\alpha_{n}, \beta_{n}-$ parametry modelu.

Tabela 4.3. Parametry modelu - współczynnik wpływu natężenia ruchu

\begin{tabular}{|l|l|l|l|l|l|l|l|l|l|}
\hline $\begin{array}{c}\text { Parame- } \\
\text { try }\end{array}$ & \multicolumn{1}{|c|}{ A } & \multicolumn{1}{|c|}{ E2 } & \multicolumn{1}{|c|}{ E1 } & \multicolumn{1}{|c|}{ K2 } & W2u & \multicolumn{1}{|c|}{ W2 } & K1 & W1u & W1z \\
\hline$\alpha_{n}$ & 0,95 & 0,95 & 0,95 & 0,95 & 0,95 & 0,95 & 0,95 & 0,95 & 0,95 \\
\hline$\beta_{n}$ & 0,00015 & 0,00015 & 0,00004 & 0,00015 & 0,00018 & 0,00020 & 0,00005 & 0,00007 & 0,00009 \\
\hline
\end{tabular}

Źródło: opracowanie własne na podstawie Rosik, Śleszyński (2009).

Oddziaływanie natężenia ruchu na średnią prędkość przejazdu wzrasta wraz z udziałem samochodów ciężarowych w natężeniu ruchu ogółem. Ich liczbę uwzględnia się poprzez przeliczanie na tzw. pojazdy umowne. W niniejszej analizie przyjęto, że przeliczniki przyjmują wartości od $1,7 \mathrm{w}$ przypadku autostrad i dróg ekspresowych do 5 przy odcinkach dróg lokalnych. Ponadto natężenie ruchu w mniejszym stopniu warunkuje średnią prędkość przejazdu, gdy podróż odbywa się drogą wielopasmową, umożliwiającą manewry wyprzedzania. W celu aktualizacji danych dotyczących natężenia ruchu w stosunku do 2010 r. przeprowadzono aktualizację zgodnie z metodologią GDDKiA. W założeniach do pro- 
gnoz ruchu ${ }^{16}$ dla poszczególnych podregionów w województwie łódzkim ustalono wzrosty w stosunku do $2010 \mathrm{r}$. na poziomie: $12,5 \%$ dla dróg w podregionie łódzkim i mieście Łódź oraz 11,9\% dla podregionu piotrkowskiego, sieradzkiego i skierniewickiego. W zależności, w którym podregionie zlokalizowany był dany odcinek badawczy, zwiększano charakterystyczne dla niego natężenie ruchu o odpowiednią wartość procentową. Dane uzyskane na podstawie GPR 2010 nie pozwalają jednak na kompletną analizę. Nie dostarczają bowiem informacji o ruchu pojazdów na drogach znajdujących się na terenie miast na prawach powiatu oraz na tych odcinkach, które włączano do użytkowania po pomiarze. Dlatego też dane dla odcinków dróg leżących w Łodzi, Piotrkowie Trybunalskim oraz Skierniewicach, drogi ekspresowej S14, obwodnicy Opoczna oraz odcinków autostrad A1 i A2 odpowiednio na północ i wschód od Strykowa ${ }^{17}$ pozyskano na podstawie autorskiego pomiaru ruchu ${ }^{18}$, pozwalającego, na podstawie danych od usługodawców zewnętrznych, określić liczbę pojazdów oraz ich średnią prędkość na poszczególnych odcinkach sieci transportowej. Przy ustalaniu natężenia ruchu ogółem w pojazdach na dobę zastosowano metodologię przyjętą w Wytycznych organizacji i przeprowadzenia Generalnego Pomiaru Ruchu w 2010 roku na drogach krajowych ${ }^{19}$. Przyjęto wariant punktów typu G, tzn. wzięto pod uwagę pięć pomiarów dziennych $(6.00-22.00)$ oraz jeden nocny (22.00-6.00). Obliczenia wykonano zgodnie ze wzorem na średni dobowy ruch w roku, wyłączając jednak z analizy ruch w soboty i w dni przedświąteczne oraz w niedziele i święta. Ponieważ autorski program nie pozawala na różnicowanie samochodów na osobowe i ciężarowe, przyjęto zatem zgodnie z danymi zawartymi w Syntezie wyników GPR $2010^{20}$, że samochody ciężarowe (bez przyczep i z przyczepami) stanowią $19,1 \%$ ogółu pojazdów.

${ }^{16}$ Zasady prognozowania wskaźników wzrostu ruchu wewnętrznego na okres 2008-2040 na sieci drogowej do celów planistyczno-projektowych, https://www.gddkia.gov.pl/userfiles/articles/p/ pismo-przewodnie-z-dnia-15032007_4423/Zalacznik_2_Zasady_prognozowania_wskaznikow_ wzrostu_2008-2040.pdf(18.09.2013).

${ }^{17}$ Wprowadzenie nowych elementów infrastruktury drogowej nie pozostaje bez wpływu na natężenie ruchu na innych drogach, szczególnie alternatywnych i tych, do których nowe drogi wprowadzają ruch.

${ }^{18}$ Do jego wykonania wykorzystano programowanie obiektowe oraz zestaw algorytmów powiązanych $\mathrm{z}$ analizą obrazu w celu ekstrakcji warstw traktujących o prędkości ruchu drogowego prezentowanych przez warstwę Traffic Google Earth. Pierwszym etapem procesu zbierania danych jest zaprojektowanie i kodowanie programu do odczytu danych o obciążeniu ruchu kołowym. Program został napisany w języku JAVA i umożliwia: odczyt wybranych elementów z obrazu przedstawionego na monitorze, kontrolę przepływu do czytania określonego koloru piksela (odpowiadającego określonej prędkości pojazdu) oraz zmodyfikowanego algorytmu Thinning Algorithm do zmniejszania liczby pikseli reprezentujących pojedynczy odczyt (jeden pojazd).

${ }^{19} \mathrm{http}$ //www.gddkia.gov.pl/userfiles/articles/g/GENERALNY_POMIAR_RUCHU_2010/ 0.1.1.1_Wytyczne_GPR_2010.pdf(18.09.2013).

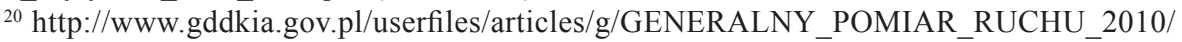
0.1.1.5_Synteza_GPR_2010.pdf(18.09.2013). 
Zastosowanie modelu pozwoliło na określenie średnich prędkości przejazdu na każdym z 260 odcinków badawczych (rycina 4.7).

Dało to również możliwość określenia czasu przejazdu każdego z odcinków (rycina 4.8), a dzięki zastosowaniu wcześniej opisanej metodologii obliczania kosztu przejazdu możliwe było również obliczenie kosztu przejazdu danego odcinka. Poruszając się po drogach wojewódzkich i krajowych ze wskazanymi przez model prędkościami, ustalono czasy i koszty przejazdu pomiędzy każdą możliwą parą miast województwa łódzkiego.

W odniesieniu do teoretycznych kosztów przejazdu, koszty wynikające z przejazdów z prędkości obliczonych w modelu są średnio o 15,9\% wyższe. Przyczyn

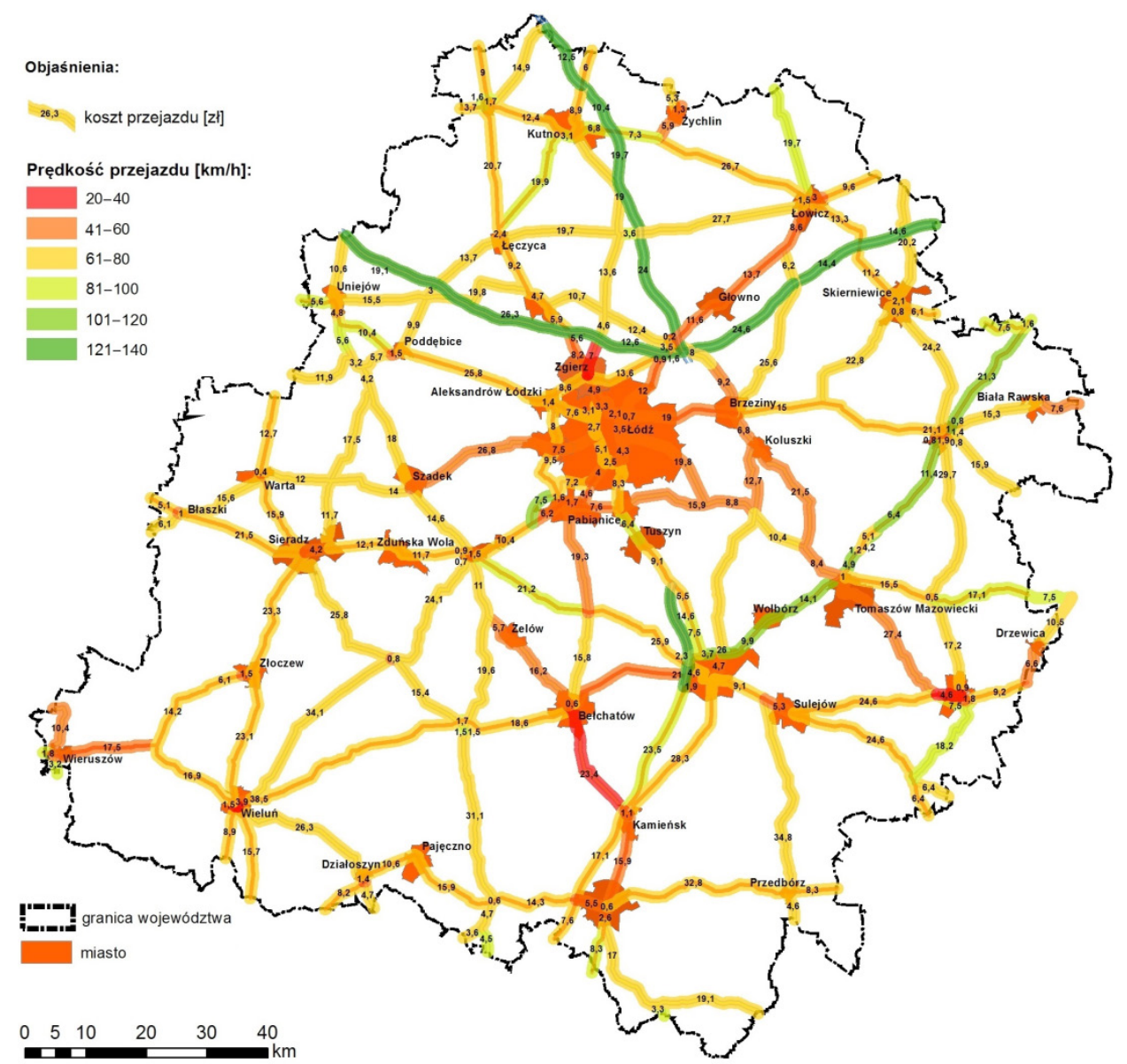

Rycina 4.7. Prędkości i koszty przejazdów na drogach krajowych i wojewódzkich w województwie łódzkim, zgodnie z modelem Źródło: opracowanie własne 
wzrostu można upatrywać m.in. w większej ilości odcinków dróg, po których według modelu, pojazdy poruszają się średnio nie szybciej niż $30 \mathrm{~km} / \mathrm{h}$. Jednakże ze względu na wyraźne różnice metodologiczne (m.in. ograniczenie wyłącznie do dróg wojewódzkich i krajowych), poszczególne teoretyczne koszty i czasy przejazdów w ujęciu bilateralnym i topologicznym oraz koszty i czasy przejazdów zgodne z modelem w ujęciu nominalnym są wartościami nieporównywalnymi.

Możliwe jest jedynie porównanie miejsc rankingowych miast województwa łódzkiego ustalonych w oparciu o topologiczny koszt lub czas teoretyczny i modelowy. Niezależnie od przyjętej metody, najwyższy poziom dostępności ekonomicznej charakteryzuje Łódź. W grupie dziesięciu najlepiej dostępnych miast

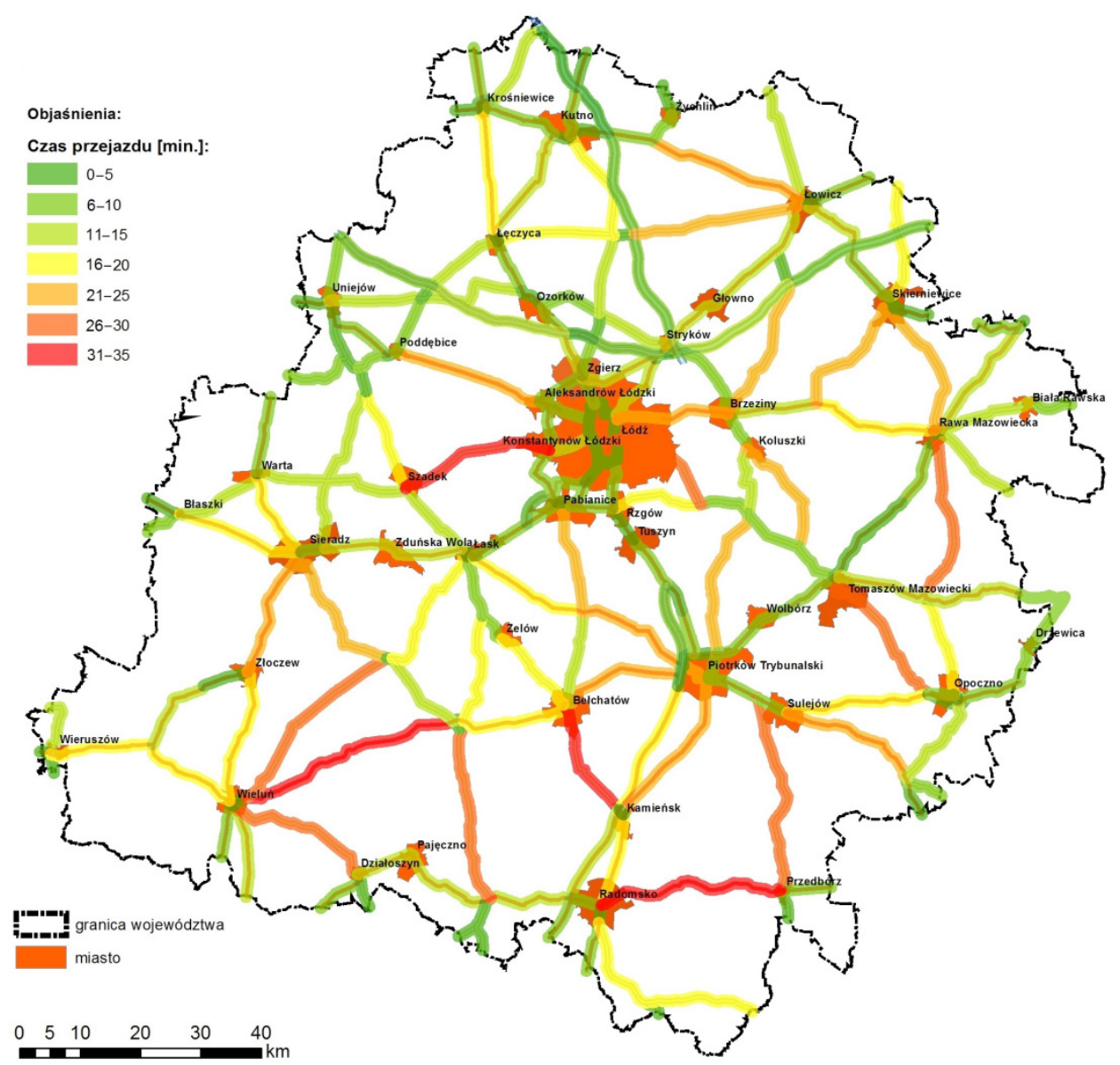

Rycina 4.8. Czasy przejazdów po drogach krajowych i wojewódzkich w województwie łódzkim, zgodnie z modelem

Źródło: opracowanie własne 
w ujęciu modelowym nie znalazł się jedynie Piotrków Trybunalski. Natomiast do grupy dołączył Zgierz. Szadek w ujęciu kosztu teoretycznego znajdował się na 10 miejscu, a podejście modelowe uplasowało go na 3 pozycji. Najniższy poziom dostępności ekonomicznej niezmiennie dotyczy Wieruszowa. Zastosowanie modelu potwierdziło również niski poziom dostępności ekonomicznej Drzewicy. Urealniony koszt przejazdu nieznacznie poprawił pozycje Białej Rawskiej kosztem Wielunia, którego dostępność w ujęciu modelowym wyraźnie się pogorszyła.

Wzrosty czasów przejazdu pomiędzy miastami województwa łódzkiego w ujęciu modelowym, w stosunku do czasów teoretycznych, są znacznie większe niż w zakresie analizy kosztów. Średnio zwiększają się one o 31,9\%. Niezależnie od zastosowanej metody najwyższe poziomy dostępności charakteryzują Łódź, Pabianice oraz Konstantynów Łódzki. Podejście modelowe pozwoliło Szadkowi na dołączenie do grupy dziesięciu miast o najwyższej dostępności. Wyraźnie jednak pogorszyła się pozycja Zgierza oraz Tuszyna. Wynika to w dużej mierze z konieczności przejazdu przez Łódź, na terenie której stuprocentowy udział terenów zabudowanych, maksymalne w województwie liczby mieszkańców w zakresie kilometrowej ekwidystanty od dróg i wysoki poziom natężenia ruchu znacznie obniżają średnią prędkość jazdy. Podejście modelowe nie zmieniło najgorszej pozycji Wieruszowa. W grupie miast, do których dojazd wymaga najwięcej czasu, znalazło się Pajęczno. 


\section{DOSTĘPNOŚĆ TRANSPORTOWA MIAST - UJĘCIE SYNTETYCZNE}

W celu pełnej analizy zróżnicowania dostępności transportowej miast województwa łódzkiego konieczne jest przedstawienie, poza wynikami zastosowania poszczególnych metod zawartych w opracowaniu, również wnioskowania o charakterze syntetycznym. Do wyznaczenia syntetycznej miary dostępności transportowej miast województwa łódzkiego wykorzystano metodę standaryzacji zmiennych. Ocenę przeprowadzono etapami. Najpierw dokonano wyboru zmiennych. Spośród wszystkich 58 cech do dalszych analiz wyselekcjonowano określoną grupę w taki sposób, aby wnosiła najbardziej istotne informacje o badanych zjawiskach, wykazywała znaczne zróżnicowanie przestrzenne i nie wskazywała wysokiego poziomu korelacji między sobą. Wzięto również pod uwagę to, że uwzględnienie zbyt wielu mierników utrudnia otrzymanie przejrzystej syntezy i zaciemnia niekiedy obraz badanego zjawiska.

Kierując się wyżej wymienionymi zasadami, do obliczenia syntetycznego miernika dostępności transportowej wybrano zmienne reprezentujące wszystkie trzy wydzielone wcześniej grupy mierników, określonych jako: dostępność potencjalna (wynikająca ze stanu i układu sieci infrastruktury transportowej), dostępność w ujęciu transportu zbiorowego oraz indywidualnego transportu samochodowego.

Obok wyboru wskaźników, które należy uwzględnić przy poszukiwaniu syntetycznego miernika dostępności transportowej, drugim problemem, jaki należało rozwiązać, było znalezienie metody jego obliczenia. Podstawowa trudność polegała na tym, że poszczególne mierniki wyrażone były w różnych jednostkach. Ponieważ w utworzonych macierzach danych nie znalazły się cechy jakościowe, toteż celowe okazało się zastosowanie metody standaryzacji zmiennych, pozwalającej na sprowadzenie różnych miar wielkości uwzględnionych mierników do swego rodzaju wspólnego mianownika. Uzyskane wyniki dla każdego z miast stanowią wielkości różnicujące badane jednostki, które umożliwiają ocenę porównawczą aktualnej dostępności transportowej w badanych układach osadniczych.

W niniejszej pracy podstawą do obliczenia syntetycznego miernika dostępności transportowej była następująca procedura. Określono odległość stanowiącą ilość odchyleń standardowych danego wyniku od średniej dla danej zmiennej. 
Innymi słowy wskazano, na ile dany wynik, dana wartość cechy dla konkretnego miasta jest odstająca od średniego wyniku. Standaryzując wyniki, przyjęto wzór:

$$
Z=\frac{x-\mu}{\sigma},
$$

gdzie:

$Z$ - wynik testu $Z$,

$x$ - obserwowana wartość zmiennej,

$\mu$-wartość oczekiwana, średnia,

$\sigma$ - odchylenie standardowe.

Przekształcając każdy otrzymany w pomiarze wynik poprzez zastosowanie wzoru standaryzacji, uzyskiwana jest znormalizowana miara, której wartość oczekiwana (średnia) wynosi 0 , a wariancja równa jest 1 . Pozwala to na określenie, na ile dany wynik $(x)$ jest odległy od wartości średniej.

Uzyskane dzięki przeprowadzonej procedurze standaryzacji wartości pozwalają na porównanie analizowanych miast $\mathrm{i}$ ich uszeregowanie według poziomu dostępności transportowej. Badane jednostki uporządkowano w kolejności malejącej pod względem wielkości syntetycznego miernika i zestawiono w tabelach 5.1-5.7. Przyjęto, że im większa jest ta wielkość, tym dostępność transportowa danego ośrodka miejskiego jest korzystniejsza.

W pierwszej kolejności analizie poddano dostępność transportową miast województwa łódzkiego w ujęciu potencjalnym. Dokonano jej w odniesieniu do infrastruktury drogowej, kolejowej oraz tramwajowej. Spośród 30 zmiennych określających, poprzez ocenę zainwestowania infrastrukturalnego, poziom potencjalnej dostępności miast województwa łódzkiego, wyznaczono ją w wymiarze sieci drogowej za pomocą odległości fizycznej rzeczywistej drogowej oraz w wariancie najszybszym dzięki potencjałowi w sieci drogowej (efektywne połaczenia), drogowej dostępności topologicznej w wariacie wewnątrz- i międzyregionalnym, drogowemu współczynnikowi $r$ oraz średnioważonemu wskaźnikowi wyposażenia infrastrukturalnego dla sieci drogowej. Reprezentują one każdą $\mathrm{z}$ grup metod zastosowanych $\mathrm{w}$ badaniu infrastruktury transportowej: pomiar odległości, analizę potencjałową, ujęcie grafowe oraz wskaźnik średnioważony. Zsumowanie wyników osiągniętych przez każdy z ośrodków w zakresie wybranych zmiennych pozwoliło na stworzenie rankingu miast województwa łódzkiego pod względem potencjalnej dostępności drogowej (tabela 5.1). Widoczna jest wyraźna zależność pomiędzy spadkiem poziomu dostępności miast i ich oddalaniem się od centrum województwa. Potwierdza to, obliczony dla odległości fizycznych pomiędzy miastami i liczby punktów określających potencjalną dostępność drogową, współczynnik korelacji rang Spearmana. Przyjmując wartość 0,92, wskazuje na bardzo silną dodatnią współzależność. 
Tabela 5.1. Miasta województwa łódzkiego pod względem potencjalnej dostępności drogowej

\begin{tabular}{|c|c|c|c|c|c|c|c|}
\hline Miasto & $\begin{array}{c}\text { Suma } \\
\text { pkt }\end{array}$ & Miasto & $\begin{array}{c}\text { Suma } \\
\text { pkt }\end{array}$ & Miasto & $\begin{array}{c}\text { Suma } \\
\text { pkt }\end{array}$ & Miasto & $\begin{array}{c}\text { Suma } \\
\text { pkt }\end{array}$ \\
\hline 1. Łódź & 14,22 & 12. Brzeziny & 3,34 & 23. Wolbórz & $-0,43$ & 34. Warta & $-4,03$ \\
\hline $\begin{array}{l}\text { 2. Konstantynów } \\
\text { Łódzki }\end{array}$ & 8,11 & 13. Bełchatów & 2,33 & 24. Radomsko & $-0,54$ & $\begin{array}{l}\text { 35. Krośnie- } \\
\text { wice }\end{array}$ & $-4,85$ \\
\hline $\begin{array}{l}\text { 3. Piotrków } \\
\text { Trybunalski }\end{array}$ & 6,75 & 14. Szadek & 1,52 & 25. Poddębice & $-0,93$ & 36. Kutno & $-5,12$ \\
\hline 4. Pabianice & 6,64 & 15. Sulejów & 0,88 & 26. Łęczyca & $-1,36$ & 37. Pajęczno & $-5,29$ \\
\hline 5. Tuszyn & 5,75 & 16. Ozorków & 0,50 & 27. Uniejów & $-1,72$ & $\begin{array}{l}38 \text {. Przed- } \\
\text { bórz }\end{array}$ & $-5,34$ \\
\hline $\begin{array}{l}\text { 6. Aleksandrów } \\
\text { Łódzki }\end{array}$ & 5,41 & 17. Zelów & 0,43 & 28. Łowicz & $-2,00$ & 39. Żychlin & $-5,50$ \\
\hline 7. Stryków & 4,52 & 18. Kamieńsk & 0,38 & 29. Wieluń & $-2,03$ & 40. Błaszki & $-5,72$ \\
\hline 8. Koluszki & 4,14 & $\begin{array}{l}19 . \text { Skiernie- } \\
\text { wice }\end{array}$ & 0,25 & $\begin{array}{l}\text { 30. Rawa Ma- } \\
\text { zowiecka }\end{array}$ & $-2,33$ & $\begin{array}{l}\text { 41. Biała } \\
\text { Rawska }\end{array}$ & $-5,90$ \\
\hline 9. Rzgów & 3,86 & $\begin{array}{l}\text { 20.Tomaszów } \\
\text { Mazowiecki }\end{array}$ & $-0,02$ & 31. Sieradz & $-2,74$ & 42. Drzewica & $-6,08$ \\
\hline 10. Zgierz & 3,53 & 21. Głowno & $-0,07$ & 32. Złoczew & $-3,30$ & $\begin{array}{l}\text { 43. Działo- } \\
\text { szyn }\end{array}$ & $-6,20$ \\
\hline 11. Lask & 3,52 & $\begin{array}{l}\text { 22. Zduńska } \\
\text { Wola }\end{array}$ & $-0,37$ & 33. Opoczno & $-3,76$ & $\begin{array}{l}\text { 44. Wieru- } \\
\text { szów }\end{array}$ & $-8,21$ \\
\hline
\end{tabular}

Źródło: opracowanie własne.

Kolejnej analizie poddano potencjalną dostępność w ujęciu infrastruktury kolejowej. W celu określenia rankingu miast województwa łódzkiego zsumowano punkty uzyskane przez poszczególne jednostki w odniesieniu do takich zmiennych, jak: odległość fizyczna rzeczywista kolejowa oraz w wariancie z uwzględnieniem kolei wąskotorowej, potencjał w sieci kolejowej (efektywne połaczenia), kolejowa dostępność topologiczna $\mathrm{w}$ wariacie wewnątrz- i międzyregionalnym, kolejowy współczynnik $r$ oraz średnioważony wskaźnik wyposażenia infrastrukturalnego dla sieci kolejowej. Stworzona w ten sposób lista rankingowa (tabela 5.2). nie potwierdza wcześniej wskazanej prawidłowości (współczynnik wynosi 0,28$)$. Sytuację tę determinuje przebieg linii kolejowych, a przede wszystkim brak dostępu do niej licznej grupy miast centralnie położonego Łódzkiego Obszaru Metropolitalnego.

W celu określenia potencjalnej dostępności miast wynikającej z przebiegu linii tramwajowych sumowaniu poddano punkty uzyskane przez ośrodki dla następujących zmiennych: odległość fizyczna rzeczywista tramwajowa, potencjał w sieci tramwajowej (efektywne połaczenia), tramwajowa dostępność topologiczna, tramwajowy współczynnik $r$ oraz średnioważony wskaźnik wyposaże- 
Tabela 5.2. Miasta województwa łódzkiego pod względem potencjalnej dostępności kolejowej

\begin{tabular}{|c|c|c|c|c|c|c|c|}
\hline Miasto & $\begin{array}{c}\text { Suma } \\
\text { pkt }\end{array}$ & Miasto & $\begin{array}{l}\text { Suma } \\
\text { pkt. }\end{array}$ & Miasto & $\begin{array}{c}\text { Suma } \\
\text { pkt }\end{array}$ & Miasto & $\begin{array}{c}\text { Suma } \\
\text { pkt }\end{array}$ \\
\hline 1. Łódź & 12,31 & 12. Głowno & 0,67 & 23. Żychlin & $-3,04$ & $\begin{array}{l}\text { 34. Aleksandrów } \\
\text { Łódzki }\end{array}$ & $-18,94$ \\
\hline 2. Koluszki & 9,25 & 13. Szadek & 0,28 & $\begin{array}{l}24 \text {. Bełcha- } \\
\text { tów }\end{array}$ & $-3,14$ & 35. Krośniewice & $-19,10$ \\
\hline 3. Zgierz & 7,03 & 14. Łęczyca & 0,06 & 25. Błaszki & $-3,36$ & 36. Uniejów & $-19,58$ \\
\hline 4. Pabianice & 6,87 & 15. Lowicz & 0,02 & 26. Drzewica & $-3,49$ & 37. Warta & $-19,71$ \\
\hline 5. Lask & 5,59 & $\begin{array}{l}\text { 16. Działo- } \\
\text { szyn }\end{array}$ & $-0,14$ & 27. Wieluń & $-4,00$ & 38. Brzeziny & $-19,80$ \\
\hline $\begin{array}{l}\text { 6. Piotrków } \\
\text { Trybunalski }\end{array}$ & 3,52 & $\begin{array}{l}\text { 17. Ka- } \\
\text { mieńsk }\end{array}$ & $-0,61$ & $\begin{array}{l}\text { 28. Biała } \\
\text { Rawska }\end{array}$ & $-6,00$ & 39. Wolbórz & $-19,83$ \\
\hline 7. Ozorków & 2,98 & $\begin{array}{l}\text { 18. Radom- } \\
\text { sko }\end{array}$ & $-1,49$ & $\begin{array}{l}\text { 29. Wieru- } \\
\text { szów }\end{array}$ & $-6,33$ & 40. Zelów & $-19,91$ \\
\hline $\begin{array}{l}\text { 8. Tomaszów } \\
\text { Mazowiecki }\end{array}$ & 2,61 & 19. Sieradz & $-1,59$ & $\begin{array}{l}\text { 30. Rawa } \\
\text { Mazowiecka }\end{array}$ & $-7,01$ & 41. Tuszyn & $-20,31$ \\
\hline $\begin{array}{l}\text { 9. Zduńska } \\
\text { Wola }\end{array}$ & 2,13 & 20. Kutno & $-2,74$ & 31. Pajęczno & $-17,79$ & 42. Sulejów & $-21,15$ \\
\hline $\begin{array}{l}\text { 10. Skiernie- } \\
\text { wice }\end{array}$ & 1,41 & 21. Opoczno & $-2,84$ & $\begin{array}{l}\text { 32. Konstan- } \\
\text { tynów Łódz- } \\
\text { ki }\end{array}$ & $-17,85$ & 43. Przedbórz & $-21,15$ \\
\hline 11. Stryków & 1,02 & $\begin{array}{l}\text { 22. Poddę- } \\
\text { bice }\end{array}$ & $-2,91$ & 33. Rzgów & $-18,17$ & 44. Złoczew & $-21,15$ \\
\hline
\end{tabular}

Źródło: opracowanie własne.

nia infrastrukturalnego dla sieci tramwajowej (włączono jedynie miasta objęte oddziaływaniem sieci tramwajowej). W wyniku tego stworzono ranking złożony z 11 miast, posiadających potencjalną dostępność do sieci tramwajowej (tabela 5.3). Wyraźnie wyróżniają się w nim, pod względem liczby punktów, miasta z rzeczywistą dostępnością do sieci.

Chcąc ocenić potencjalną dostępność transportową miast województwa łódzkiego w ujęciu całościowym, wzięto pod uwagę wykorzystane dotychczas zmienne. Zróżnicowanie wartości syntetycznych miernika dostępności komunikacyjnej w badanych jednostkach jest znaczne. Największa bowiem suma punktów wynosi 32,9 dla Łodzi, najmniejsza zaś tylko - 37,4 dla Przedborza. Kolejność jednostek pod względem wartości syntetycznego miernika potencjalnej dostępności transportowej odznacza się wysoką pozycją układów osadniczych Łódzkiego Obszaru Metropolitalnego. 
Tabela 5.3. Miasta województwa łódzkiego pod względem potencjalnej dostępności tramwajowej

\begin{tabular}{|l|c|}
\hline \multicolumn{1}{|c|}{ Miasto } & Suma pkt \\
\hline 1. Łódź & 6,34 \\
\hline 2. Zgierz & 2,34 \\
\hline 3. Konstantynów Lódzki & 0,06 \\
\hline 4. Pabianice & 0,03 \\
\hline 5. Ozorków & $-0,58$ \\
\hline 6. Aleksandrów Łódzki & $-6,13$ \\
\hline 7. Rzgów & $-8,44$ \\
\hline 8. Łask & $-8,91$ \\
\hline 9. Stryków & $-9,80$ \\
\hline 10. Tuszyn & $-9,99$ \\
\hline 11. Brzeziny & $-10,16$ \\
\hline
\end{tabular}

Źródło: opracowanie własne.

Analiza jednostek osadniczych pod względem wielkości syntetycznego miernika dostępności transportowej pozwala również na ocenę stopnia podobieństwa badanych jednostek. W związku z tym, może on stanowić podstawę dokonania podziału badanej zbiorowości na grupy klasyfikacyjne. Kolejnym problemem przy grupowaniu miast jest określenie wartości granicznych przedziałów klasowych syntetycznego miernika potencjalnej dostępności transportowej.

W celu obiektywnego i ścisłego wyodrębnienia przedziałów klasowych, a tym samym dokonania systematyki układów osadniczych, posłużono się jedną z miar statystycznych, a mianowicie odchyleniem standardowym. Rozpiętość klas równa jest wartości odchylenia standardowego, zaś granice klas to kolejne wielokrotności odchylenia, dodawane i odejmowane od średniej arytmetycznej zbioru, do momentu sklasyfikowania wszystkich danych. Najniższa i najwyższa klasa mają różną rozpiętość, ponieważ dolna granica najniższej klasy i górna granica najwyższej klasy równają się odpowiednio najniższej i najwyższej wartości szeregu kartowanych danych. Dodając i odejmując wartości odchylenia od średniej, otrzymamy kolejne liczby, które można wykorzystać jako granice przedziałów.

Wartości syntetycznego miernika dostępności były podstawą do przeprowadzenia grupowania jednostek osadniczych i stanowiły kryterium określenia systematyki. Na ich podstawie wyróżniono pięć grup układów osadniczych o różnej potencjalnej dostępności transportowej: bardzo dobrej, dobrej, średniej, złej i bardzo złej. W wyniku przyjęcia dwóch kryteriów, tj. wielkości miast określonych 
liczbą mieszkańców w podziale na miasta małe (do 20 tys. mieszkańców), średnie (powyżej 20 tys., do 100 tys. mieszkańców) i duże (powyżej 100 tys. mieszkańców) oraz wartości syntetycznego wskaźnika potencjalnej dostępności transportowej, wyróżniono 15 typów układów osadniczych. Ze względu na zróżnicowanie obu kryteriów, jedynie do 8 typów należą poszczególne jednostki osadnicze. Schemat dokonanej typologii przedstawiono na rycinie 5.1.

W grupie małych miast województwa łódzkiego przeważają liczebnie jednostki o złej dostępności transportowej. Żadne z nich nie osiąga poziomu dostępności bardzo dobrej. Najwyższy poziom charakteryzuje Koluszki oraz Łask, osiągające poziom dobrej dostępności. Grupa dziewięciu małych miast stanowi jedyne ośrodki charakteryzujące się bardzo złym poziomem dostępności potencjalnej. Miasta średniej wielkości w największej liczbie przypadków osiągają średni i zły poziom potencjalnej dostępności transportowej. Jedynie Pabianice, Zgierz, Ozorków i Piotrków Trybunalski charakteryzują się jej wysokim poziomem. Łódź, jako jedyne duże miasto regionu, posiada najwyższy poziom potencjalnej dostępności transportowej. Pobieżna analiza wykresu sugerować może występowanie wyraźnej zależności pomiędzy wielkością miasta wyrażoną liczbą mieszkańców a poziomem jego potencjalnej dostępności. Istotnie, współczynnik korelacji rang Spearmana wskazuje dodatnią zależność $(0,6)$, a ponadto jest to współzależność silniejsza niżeli ta występująca w związku z topologiczną odległością fizyczną pomiędzy miastami, której siłę współczynnik określił na 0,48. Odniesienie do średniej dla syntetycznego wskaźnika dostępności i mieszkańców wskazuje, że liczebnie przeważają miasta, które mają lepszą dostępność transportową niż wynikałoby to $\mathrm{z}$ ich potencjału demograficznego, a jednostką, w przypadku której dysproporcja jest najsilniejsza, są Poddębice. Kutno natomiast, obok Przedborza i Zelowa, odznacza się najniższą wartością wskaźnika w stosunku do jego wielkości wyrażonej liczbą mieszkańców.

Postępując zgodnie z przyjętym algorytmem, analizie poddano dostępność miast województwa łódzkiego w świetle transportu zbiorowego. Spośród 24 zmiennych określających każdy z trzech badanych środków transportu zbiorowego do wyznaczenia poziomu dostępności w ujęciu zbiorowego transportu samochodowego, użyto następujące zmienne: ciążenie komunikacyjne - opór przestrzeni wyrażony w jednostkach długości, czasu i kosztu, liczbę przystanków w zasięgu izochrony 60 minut oraz liczbę bezpośrednich połączeń. Pozwalają one na uchwycenie efektywności transportu pod kątem częstotliwości, długości, kosztu i czasu kursów. Zsumowanie wyników uzyskanych przez miasta w zakresie stosownych zmiennych pozwoliło na stworzenie listy rankingowej przedstawionej w tabeli 5.4. Odniesienie kolejności miast do ich wielkości wyrażonych liczbą mieszkańców i wzajemnych fizycznych oddaleń wskazuje, że w obydwu zależnościach występuje wyraźna korelacja dodatnia. Siła współzależności jest bardzo podobna, gdyż współczynnik korelacji rang Spearmana wskazuje odpowiednio 0,65 i 0,54 . 


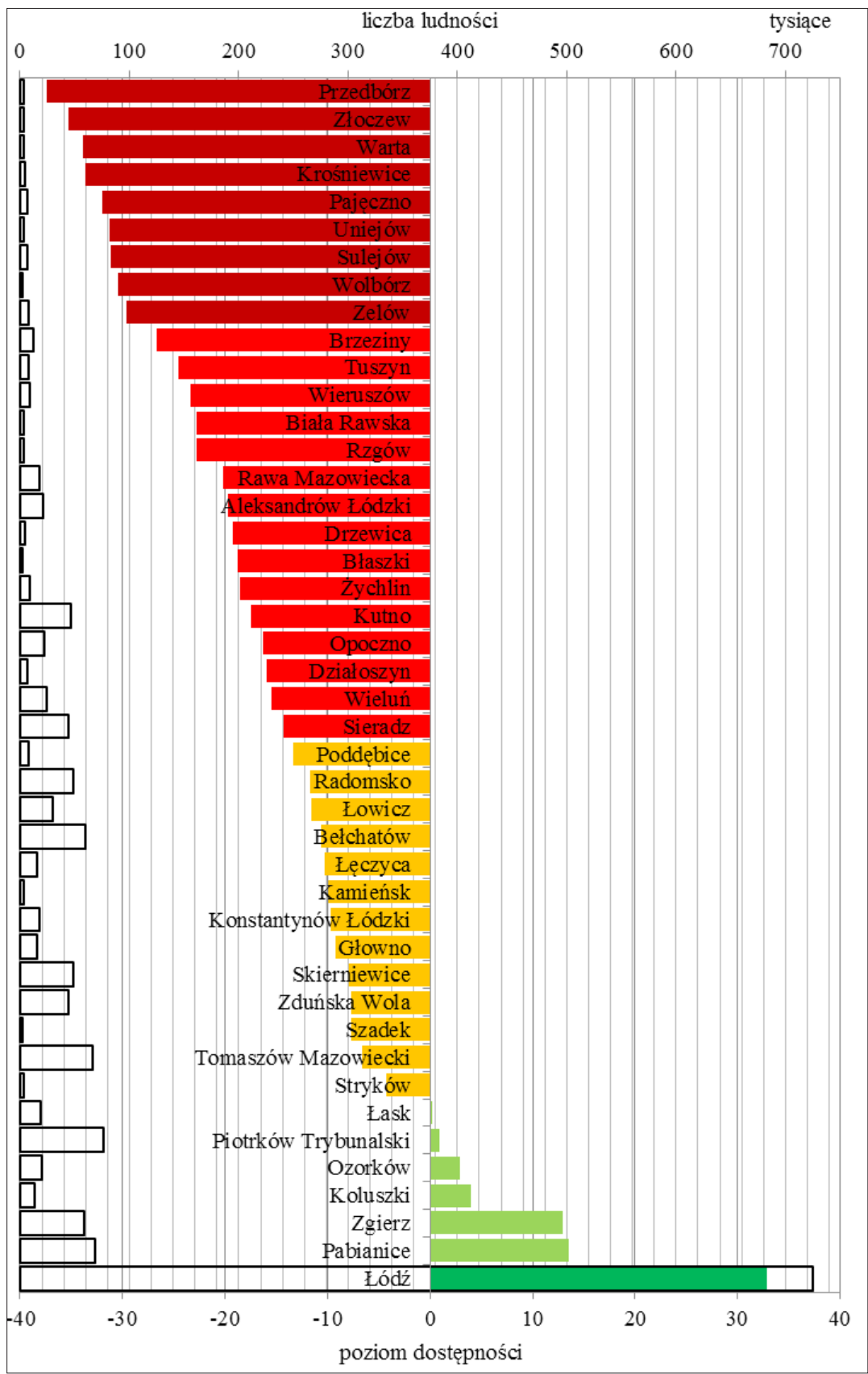

dostępność: bardzo dobra, dobra, średnia, zła, bardzo zła

Rycina 5.1. Klasyfikacja miast województwa łódzkiego pod względem potencjalnej dostępności transportowej

Źródło: opracowanie własne 
Tabela 5.4. Miasta województwa łódzkiego pod względem samochodowego transportu zbiorowego

\begin{tabular}{|c|c|c|c|c|c|c|c|}
\hline Miasto & $\begin{array}{c}\text { Suma } \\
\text { pkt }\end{array}$ & Miasto & $\begin{array}{c}\text { Suma } \\
\text { pkt }\end{array}$ & Miasto & $\begin{array}{c}\text { Suma } \\
\text { pkt }\end{array}$ & Miasto & $\begin{array}{c}\text { Suma } \\
\text { pkt }\end{array}$ \\
\hline 1. Łódź & 26,40 & $\begin{array}{l}\text { 12. Zduńska } \\
\text { Wola }\end{array}$ & 0,04 & 23. Szadek & $-1,17$ & 34. Uniejów & $-1,58$ \\
\hline 2. Zgierz & 9,06 & 13. Sulejów & $-0,33$ & 24. Przedbórz & $-1,22$ & 35. Błaszki & $-1,67$ \\
\hline 3. Pabianice & 3,66 & $\begin{array}{l}\text { 14. Toma- } \\
\text { szów Mazo- } \\
\text { wiecki }\end{array}$ & $-0,54$ & 25. Łęczyca & $-1,24$ & 36. Kutno & $-1,71$ \\
\hline $\begin{array}{l}\text { 4. Piotrków } \\
\text { Trybunalski }\end{array}$ & 2,90 & $\begin{array}{l}\text { 15. Radom- } \\
\text { sko }\end{array}$ & $-0,58$ & 26. Wieruszów & $-1,24$ & 37. Warta & $-1,84$ \\
\hline 5. Sieradz & 1,72 & 16. Tuszyn & $-0,59$ & 27. Opoczno & $-1,26$ & 38. Zelów & $-2,04$ \\
\hline $\begin{array}{l}\text { 6. Konstanty- } \\
\text { nów Łódzki }\end{array}$ & 1,58 & $\begin{array}{l}\text { 17. Rawa } \\
\text { Mazowiecka }\end{array}$ & $-0,60$ & 28. Kamieńsk & $-1,31$ & $\begin{array}{l}\text { 39. Krośnie- } \\
\text { wice }\end{array}$ & $-2,35$ \\
\hline 7. Bełchatów & 1,10 & 18. Łowicz & $-0,77$ & 29. Złoczew & $-1,46$ & 40. Koluszki & $-2,63$ \\
\hline $\begin{array}{l}\text { 8. Aleksandrów } \\
\text { Łódzki }\end{array}$ & 0,76 & 19. Głowno & $-0,83$ & 30. Stryków & $-1,48$ & 41. Drzewica & $-2,73$ \\
\hline 9. Wieluń & 0,40 & 20. Rzgów & $-0,93$ & 31. Działoszyn & $-1,53$ & $\begin{array}{l}\text { 42. Biała } \\
\text { Rawska }\end{array}$ & $-3,00$ \\
\hline 10. Łask & 0,38 & 21. Ozorków & $-1,03$ & $\begin{array}{l}\text { 32. Skiernie- } \\
\text { wice }\end{array}$ & $-1,53$ & 43. Wolbórz & $-3,09$ \\
\hline 11. Poddębice & 0,18 & 22. Brzeziny & $-1,07$ & 33. Pajęczno & $-1,55$ & 44. Żychlin & $-3,24$ \\
\hline
\end{tabular}

Źródło: opracowanie własne.

W celu określenia rankingu miast województwa łódzkiego pod względem dostępności transportowej w ujęciu zbiorowego transportu kolejowego, użyto analogiczne zmienne jak w przypadku transportu samochodowego. Po zsumowaniu wyników uzyskanych przez każde z miast w zakresie wymienionych pięciu zmiennych uzyskano listę rankingową zawartą w tabeli 5.5.

Tabela 5.5. Miasta województwa łódzkiego pod względem kolejowego transportu zbiorowego

\begin{tabular}{|l|c|l|c|l|c|c|c|}
\hline \multicolumn{1}{|c|}{ Miasto } & $\begin{array}{c}\text { Suma } \\
\text { pkt }\end{array}$ & \multicolumn{1}{|c|}{ Miasto } & $\begin{array}{c}\text { Suma } \\
\text { pkt }\end{array}$ & \multicolumn{1}{|c|}{ Miasto } & $\begin{array}{c}\text { Suma } \\
\text { pkt. }\end{array}$ & \multicolumn{1}{c|}{ Miasto } & $\begin{array}{c}\text { Suma } \\
\text { pkt }\end{array}$ \\
\hline 1. Łódź & 17,92 & $\begin{array}{l}\text { 7. Piotrków } \\
\text { Trybunalski }\end{array}$ & 1,08 & 13. Lęczyca & $-1,25$ & 19. Błaszki & $-2,58$ \\
\hline 2. Zgierz & 6,22 & 8. Kutno & 0,84 & 14 Sieradz & $-1,29$ & 20. Kamieńsk & $-2,72$ \\
\hline 3. Pabianice & 2,23 & $\begin{array}{l}\text { 9. Tomaszów } \\
\text { Mazowiecki }\end{array}$ & 0,67 & 15. Głowno & $-1,56$ & 21. Drzewica & $-3,31$ \\
\hline 4. Koluszki & 1,58 & $\begin{array}{l}\text { 10. Zduńska } \\
\text { Wola }\end{array}$ & $-0,93$ & 16. Żychlin & $-1,65$ & 22. Opoczno & $-3,57$ \\
\hline
\end{tabular}




\begin{tabular}{|l|c|l|c|c|c|c|c|}
\hline \multicolumn{1}{|c|}{ Miasto } & $\begin{array}{c}\text { Suma } \\
\text { pkt }\end{array}$ & \multicolumn{1}{|c|}{ Miasto } & $\begin{array}{c}\text { Suma } \\
\text { pkt }\end{array}$ & \multicolumn{1}{|c|}{ Miasto } & $\begin{array}{c}\text { Suma } \\
\text { pkt. }\end{array}$ & Miasto & $\begin{array}{c}\text { Suma } \\
\text { pkt }\end{array}$ \\
\hline 5. Łowicz & 1,16 & 11. Radomsko & $-1,12$ & 17. Ozorków & $-1,91$ & 23. Wieluń & $-3,84$ \\
\hline $\begin{array}{l}\text { 6. Skiernie- } \\
\text { wice }\end{array}$ & 1,11 & 12. Lask & $-1,18$ & 18 . Stryków & $-2,00$ & $\begin{array}{l}\text { 24. Wieru- } \\
\text { szów }\end{array}$ & $-3,89$ \\
\hline
\end{tabular}

Źródło: opracowanie własne.

Dostępność miast przy założeniu podróży pociągiem determinuje przede wszystkim przebieg linii kolejowych. Ich układ w województwie łódzkim zapewnia dojazd do 24 z 44 wszystkich ośrodków. W grupie tej uwidacznia się zależność miejsca w rankingu od wielkości miasta. Nie jest ona tak wyraźna jak w przypadku komunikacji samochodowej, bowiem wskaźnik korelacji wynosi 0,66 . W dużej mierze jest to wynik wyższej częstotliwości połączeń docierających do większych miast. Wyjątek stanowią oczywiście Koluszki, które jako małe miasto, ale jednocześnie bardzo ważny węzeł kolejowy, znalazły się na wysokiej pozycji w rankingu. Oddalenie ośrodków od centrum województwa ma w przypadku transportu kolejowego niewielkie znaczenie (współczynnik wynosi jedynie 0,11 ).

$\mathrm{Z}$ pięciu miast województwa łódzkiego połączonych siecią tramwajową w świetle syntetycznego wskaźnika, biorącego pod uwagę takie zmienne, jak: ciążenie komunikacyjne, liczbę przystanków w zasięgu izochrony 60 min oraz liczbę bezpośrednich połączeń, najwyższym poziomem dostępności charakteryzuje się Łódź $(7,05)$. Kolejne miejsca zajmują: Zgierz $(2,95)$, Pabianice $(-3,05)$, Konstantynów Łódzki $(-3,46)$ i Ozorków $(-3,5)$. W odniesieniu do tak małej zbiorowości trudno wskazywać prawidłowości niezwiązane bezpośrednio z efektywnością funkcjonowania transportu tramwajowego.

Do oceny poziomu dostępności transportowej miast województwa łódzkiego, wynikającej z funkcjonującego transportu zbiorowego w ujęciu całościowym, wzięto pod uwagę 15 zmiennych, wykorzystanych w ocenie poszczególnych środków transportu. Zróżnicowanie wartości syntetycznych miernika dostępności transportowej w badanych jednostkach przekracza to występujące w przypadku podejścia potencjalnego. Największa suma punktów wynosi 51,4 dla Łodzi, najmniejsza zaś tylko -14 dla Wolborza. Analiza jednostek osadniczych pod względem wielkości syntetycznego miernika dostępności w zakresie transportu zbiorowego umożliwia ponadto ocenę stopnia podobieństwa badanych jednostek (rycina 5.2).

Z 12 typów powstałych poprzez przyjęcie kryterium wielkości miasta i wartości syntetycznego wskaźnika dostępności w transporcie zbiorowym, ze względu na zróżnicowanie obu zmiennych jedynie do 9 typów należą poszczególne jednostki osadnicze. Schemat dokonanej typologii przedstawiono na rycinie 5.2. 


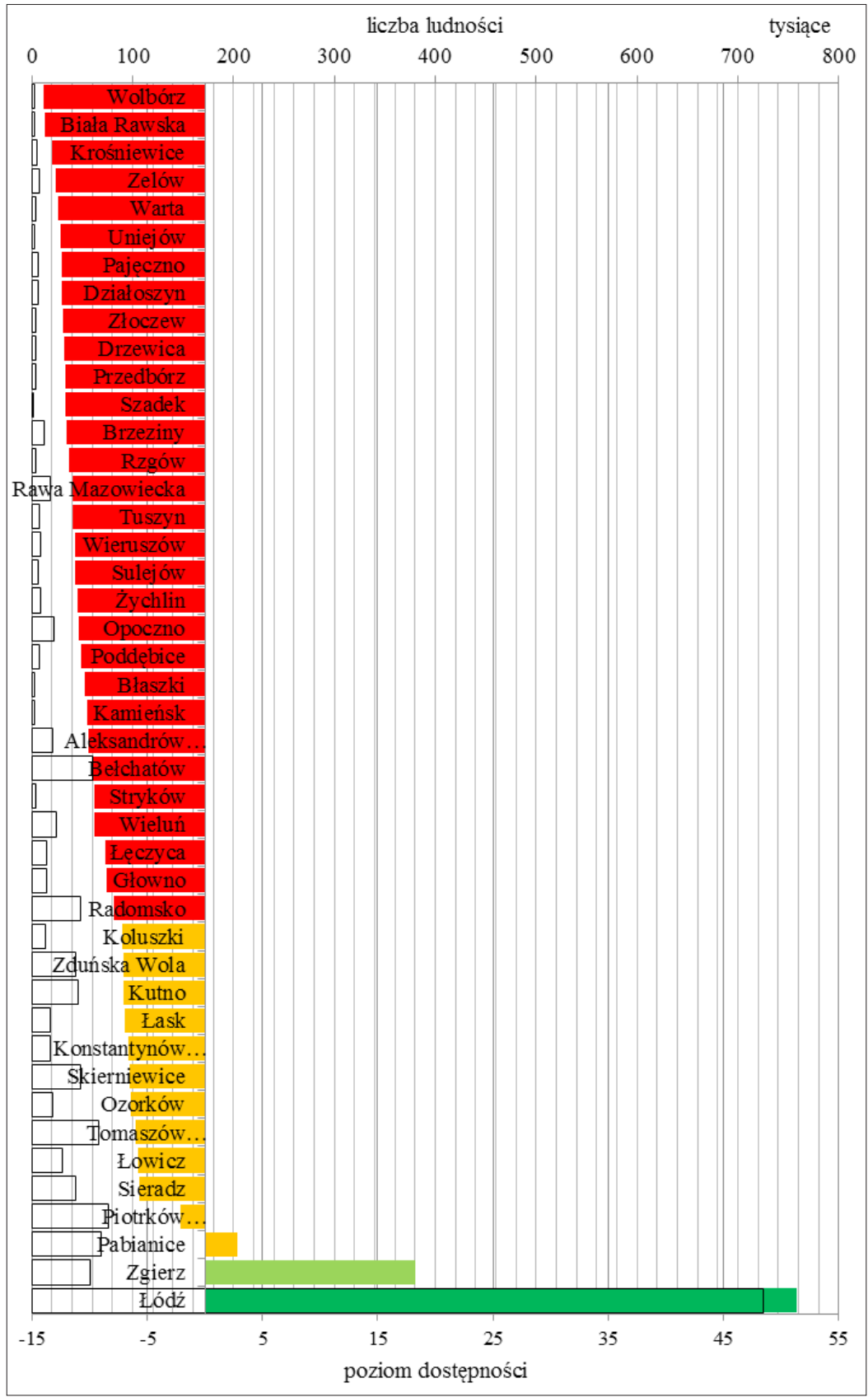

dostępność: bardzo dobra, dobra, średnia, zła

Rycina 5.2. Klasyfikacja miast województwa łódzkiego pod względem dostępności w świetle transportu zbiorowego

Źródło: opracowanie własne 
W grupie ośrodków miejskich do 20 tys. mieszkańców województwa łódzkiego przeważają liczebnie jednostki o złej dostępności transportowej w zakresie transportu zbiorowego. Żadne z nich nie osiąga poziomu dostępności bardzo dobrej. Najwyższy poziom posiada Konstantynów Łódzki, osiągając poziom średniej dostępności. Wolbórz i Biała Rawska stanowią ośrodki charakteryzujące się najniższym poziomem dostępności. Miasta średniej wielkości w największej liczbie przypadków osiągają średni poziom dostępności zapewnianej przez transport zbiorowy.

Jedynie Pabianice charakteryzują się dobrym poziomem dostępności. Podobnie jak w przypadku podejścia potencjalnego, również na płaszczyźnie analiz transportu zbiorowego, Łódź, jako jedyne duże miasto regionu, posiada bardzo wysoki poziom dostępności. Długość słupków na wykresie odpowiadających cechom poszczególnych miast wskazuje na zależność pomiędzy liczbą mieszkańców danego miasta a poziomem jego dostępności w odniesieniu do transportu zbiorowego. Potwierdza to współczynnik korelacji rang Spearmana, który siłę tej współzależności określił na poziomie 0,79 .

Znacznie słabsza relacja $(0,43)$ występuje pomiędzy poziomem dostępności a topologiczną odległością fizyczną pomiędzy miastami i tym samych ich oddaleniem od centrum województwa. Wprowadzenie do analizy średniej dla liczby punktów i mieszkańców wskazuje, że dominują liczebnie miasta, które charakteryzują się lepszą dostępnością niż wynikałoby z ich potencjału demograficznego. Przewaga ta jest nieznacznie większa niż w przypadku analizy dostępności potencjalnej. Miastem, którego poziom dostępności w ujęciu transportu zbiorowego najbardziej odbiega in plus od poziomu średniego, jest Zgierz. Natomiast Bełchatów i Rawa Mazowiecka najbardziej znacząco odbiegają od średniej in minus. Jest to jednak dysproporcja znacznie mniejsza.

Syntetycznej oceny wymaga również poziom dostępności transportowej miast województwa łódzkiego $\mathrm{w}$ świetle samochodowego transportu indywidualnego. Do badania włączono wszystkie 4 zmienne określające czas i koszt przejazdu samochodem osobowym w ujęciu topologicznym Pozwalają one na uchwycenie efektywności transportu pod kątem badania teoretycznego i modelowego. Zsumowanie punktów uzyskanych przez miasta w zakresie stosownych zmiennych pozwoliło na stworzenie listy rankingowej ze względu na czas dojazdu, przedstawionej w tabeli 5.6.

Zależność poziomu dostępności transportowej związanej z podróżą samochodem osobowym od odległości poszczególnych ośrodków od centrum województwa jest jeszcze bardziej wyraźna niż w przypadku potencjalnej drogowej dostępności transportowej (współczynnik korelacji wynosi 0,97). Przyczyn takiej sytuacji można upatrywać w braku połączeń drogowych, które w skali regionalnej ze względu na całą sieć osadniczą województwa łódzkiego zaburzałyby układ promienisto-koncentryczny wyjątkowo wysoką lub niską prędkością podróży. W pewnych relacjach bilateralnych pomiędzy miastami takimi elementami 
Tabela 5.6. Miasta województwa łódzkiego pod względem czasu dojazdu transportem indywidualnym

\begin{tabular}{|c|c|c|c|c|c|c|c|}
\hline Miasto & $\begin{array}{c}\text { Suma } \\
\text { pkt }\end{array}$ & Miasto & $\begin{array}{c}\text { Suma } \\
\text { pkt }\end{array}$ & Miasto & $\begin{array}{c}\text { Suma } \\
\text { pkt }\end{array}$ & Miasto & $\begin{array}{c}\text { Suma } \\
\text { pkt }\end{array}$ \\
\hline 1. Łódź & 5,87 & 12. Wolbórz & 0,97 & 23. Sulejów & $-0,19$ & 34. Błaszki & $-1,84$ \\
\hline 2. Pabianice & 3,89 & 13. Stryków & 0,96 & 24. Uniejów & $-0,19$ & $\begin{array}{l}\text { 35. Biała } \\
\text { Rawska }\end{array}$ & $-1,95$ \\
\hline $\begin{array}{l}\text { 3. Konstanty- } \\
\text { nów Łódzki }\end{array}$ & 2,74 & $\begin{array}{l}\text { 14. Bełcha- } \\
\text { tów }\end{array}$ & 0,82 & 25. Kamieńsk & $-0,39$ & 36. Opoczno & $-2,02$ \\
\hline 4. Lask & 2,49 & 15. Zelów & 0,78 & 26. Głowno & $-0,40$ & 37. Wieluń & $-2,04$ \\
\hline 5. Rzgów & 2,47 & $\begin{array}{l}\text { 16. Zduńska } \\
\text { Wola }\end{array}$ & 0,67 & 27. Warta & $-0,47$ & 38. Pajęczno & $-2,10$ \\
\hline $\begin{array}{l}\text { 6. Piotrków } \\
\text { Trybunalski }\end{array}$ & 2,25 & 17. Sieradz & 0,65 & $\begin{array}{l}\text { 28. Rawa } \\
\text { Mazowiecka }\end{array}$ & $-0,75$ & $\begin{array}{l}\text { 39. Krośnie- } \\
\text { wice }\end{array}$ & $-2,12$ \\
\hline $\begin{array}{l}\text { 7. Aleksan- } \\
\text { drów Łódzki }\end{array}$ & 2,13 & 18. Koluszki & 0,64 & 29. Łowicz & $-1,06$ & 40. Działoszyn & $-2,46$ \\
\hline 8. Zgierz & 2,08 & 19. Ozorków & 0,57 & $\begin{array}{l}30 . \text { Skiernie- } \\
\text { wice }\end{array}$ & $-1,07$ & 41. Żychlin & $-2,49$ \\
\hline 9. Brzeziny & 1,75 & $\begin{array}{l}\text { 20. Toma- } \\
\text { szów Mazo- } \\
\text { wiecki }\end{array}$ & 0,06 & 31. Złoczew & $-1,10$ & 42. Drzewica & $-2,62$ \\
\hline 10. Tuszyn & 1,41 & 21. Łęczyca & 0,05 & $\begin{array}{l}\text { 32. Radom- } \\
\text { sko }\end{array}$ & $-1,22$ & 43. Przedbórz & $-2,78$ \\
\hline 11. Szadek & 1,38 & 22. Poddębice & 0,04 & 33. Kutno & $-1,60$ & 44. Wieruszów & $-3,79$ \\
\hline
\end{tabular}

Źródło: opracowanie własne.

sieci drogowej są odcinki autostrad i drogi ekspresowej. Natomiast w wielu przypadkach najszybsza podróż samochodem nie wymaga poruszania się żadną z tych dróg. A nawet jeśli, to są to na tyle krótkie odcinki, że nie pojawia się efekt w postaci zaoszczędzonego czasu.

Przyjęcie odległości ekonomicznych (w ujęciu teoretycznym i modelowym) spowodowało niewielkie zmiany na liście rankingowej. Wspomniana już mniejsza zmienność stawek pieniężnych za przejechanie $1 \mathrm{~km} \mathrm{w}$ stosunku do zróżnicowania prędkości jazdy na poszczególnych odcinkach dróg województwa łódzkiego powoduje znacznie silniejsze uzależnienie pozycji danego ośrodka pod względem kosztów podróży w ujęciu topologicznym (tabela 5.7) od jego odległości od centrum województwa (współczynnik korelacji wynosi 0,98).

Do oceny poziomu dostępności transportowej miast województwa łódzkiego, wynikającej z indywidualnego transportu samochodowego w ujęciu całościowym, wzięto pod uwagę wszystkie cztery wykorzystane zmienne. Zróżnicowanie 
Tabela 5.7. Miasta województwa łódzkiego pod względem kosztu dojazdu transportem indywidualnym

\begin{tabular}{|c|c|c|c|c|c|c|c|}
\hline Miasto & $\begin{array}{c}\text { Suma } \\
\text { pkt }\end{array}$ & Miasto & $\begin{array}{c}\text { Suma } \\
\text { pkt }\end{array}$ & Miasto & $\begin{array}{c}\text { Suma } \\
\text { pkt }\end{array}$ & Miasto & $\begin{array}{c}\text { Suma } \\
\text { pkt }\end{array}$ \\
\hline 1. Łódź & 5,56 & $\begin{array}{l}\text { 12. Zduńska } \\
\text { Wola }\end{array}$ & 1,38 & 23. Sulejów & $-0,12$ & 34. Opoczno & $-1,70$ \\
\hline 2. Pabianice & 2,88 & 13. Wolbórz & 1,14 & 24. Kamieńsk & $-0,16$ & 35. Kutno & $-1,86$ \\
\hline $\begin{array}{l}\text { 3. Konstanty- } \\
\text { nów Łódzki }\end{array}$ & 2,86 & 14. Ozorków & 1,08 & 25. Łęczyca & $-0,33$ & 36. Pajęczno & $-1,86$ \\
\hline 4. Rzgów & 2,75 & 15. Stryków & 1,03 & 26. Uniejów & $-0,57$ & 37. Krośniewice & $-1,89$ \\
\hline 5. Zgierz & 2,55 & 16. Brzeziny & 1,00 & 27. Warta & $-0,97$ & 38. Błaszki & $-1,97$ \\
\hline $\begin{array}{l}\text { 6. Aleksan- } \\
\text { drów Łódzki }\end{array}$ & 2,54 & 17. Zelów & 0,95 & $\begin{array}{l}\text { 28. Rawa } \\
\text { Mazowiecka }\end{array}$ & $-1,25$ & 39. Przedbórz & $-2,31$ \\
\hline 7. Łask & 2,23 & 18. Koluszki & 0,72 & $\begin{array}{l}\text { 29. Radom- } \\
\text { sko }\end{array}$ & $-1,36$ & 40. Działoszyn & $-2,38$ \\
\hline 8. Tuszyn & 2,19 & 19. Poddębice & 0,21 & 30. Łowicz & $-1,45$ & 41, Wieluń & $-2,40$ \\
\hline 9. Szadek & 2,15 & $\begin{array}{l}\text { 20. Tomaszów } \\
\text { Mazowiecki }\end{array}$ & 0,10 & $\begin{array}{l}\text { 31. Skiernie- } \\
\text { wice }\end{array}$ & $-1,48$ & $\begin{array}{l}\text { 42. Biała Raw- } \\
\text { ska }\end{array}$ & $-2,65$ \\
\hline $\begin{array}{l}\text { 10. Bełcha- } \\
\text { tów }\end{array}$ & 1,52 & 21. Głowno & 0,00 & 32. Złoczew & $-1,48$ & 43. Drzewica & $-2,79$ \\
\hline $\begin{array}{l}\text { 11. Piotrków } \\
\text { Trybunalski }\end{array}$ & 1,41 & 22. Sieradz & $-0,09$ & 33. Żychlin & $-1,65$ & 44. Wieruszów & $-3,54$ \\
\hline
\end{tabular}

Źródło: opracowanie własne.

wartości syntetycznych miernika dostępności transportowej w badanych jednostkach jest najmniejsze z prezentowanych dotychczas (rycina 5.3).

Pozwoliło to na utworzenie czterech przedziałów syntetycznego miernika, obejmujących jednostki o bardzo dobrej, dobrej, średniej i złej dostępności. Miasta województwa łódzkiego zgrupowały się w ośmiu spośród piętnastu powstałych w wyniku nałożenia na siebie liczby ludności i poziomu dostępności w grupach typologicznych.

W grupie małych miast województwa łódzkiego przeważają liczebnie jednostki o średniej dostępności transportowej. Uzależnienie poziomu dostępności poszczególnych ośrodków od ich odległości od centrum regionu, a nie od wielkości powoduje, że jednostki grupują się równomiernie w każdej z utworzonych przedziałów klasowych. Najwyższy poziom dostępności osiąga Łódź. Wieruszów zaś odznacza się wyraźnie najniższym poziomem i wraz z Drzewicą, Przedborzem, Działoszynem, Białą Rawską, Wieluniem, Żychlinem, Krośniewicami i Pajęcznem stanowią ośrodki charakteryzujące się złą dostępnością w ujęciu transportu indywidualnego. Miasta średniej wielkości w największej liczbie przypadków 


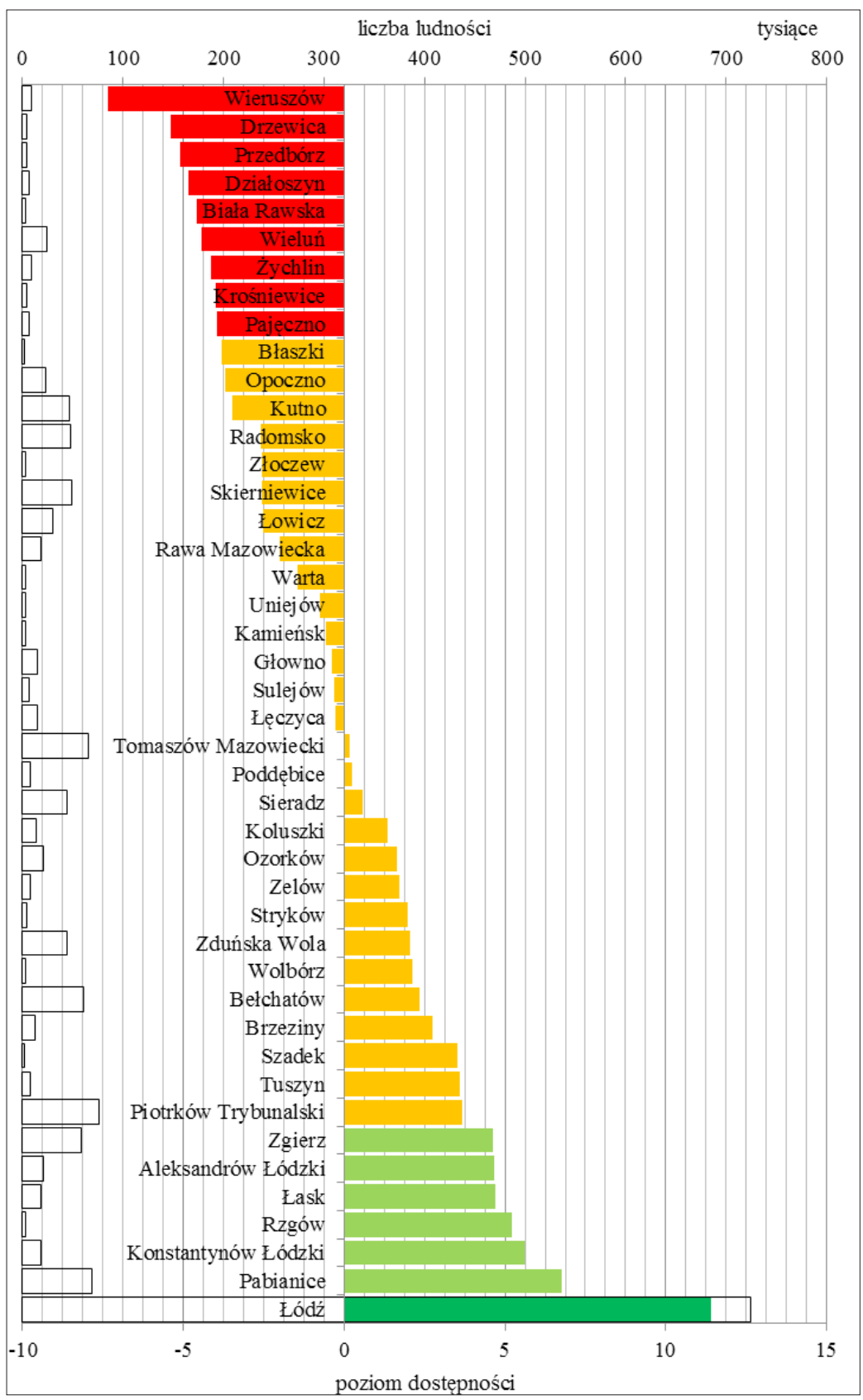

dostępność: bardzo dobra, dobra, średnia, zła

Rycina 5.3. Klasyfikacja miast województwa łódzkiego pod względem dostępności w świetle transportu indywidualnego

Źródło: opracowanie własne 
osiągają średni poziom. Spośród prezentowanych dotychczas podejść całościowych, w przypadku transportu indywidualnego widoczna jest korelacja pomiędzy poziomem dostępności miasta a jego oddaleniem od centrum regionu, która tak jak w ujęciu czasowym i kosztowym charakteryzuje się współczynnikiem niemal równym jedności. Oddalenie poszczególnych wyników uzyskanych przez miasta województwa łódzkiego od średniego poziomu wskazuje na liczebną przewagę ośrodków, które charakteryzują się lepszą dostępnością niż wskazywałby na to ich potencjał demograficzny. Sytuacja taka dotyczy 29 miast regionu. Najbardziej pozytywną relacją obu zmiennych na tym tle charakteryzuje się Rzgów. Natomiast Wieluń, Kutno i Wieruszów dominują w grupie jednostek z niekorzystnym stosunkiem liczby mieszkańców i wyników obrazujących dostępność. Ich oddalenie od średniej jest jednak znacznie mniejsze.

Zestawiając wskaźniki syntetyczne określające dostępność miast województwa łódzkiego w ujęciu potencjalnym, transportu zbiorowego i indywidualnego, określono dostępność w ujęciu holistycznym. W tym celu każdemu z miast zsumowano wskaźniki uzyskane w zakresie trzech wspomnianych wymiarów dostępności.

Otrzymano pięć grup wartości syntetycznego miernika dostępności transportowej w ujęciu holistycznym, które dodatkowo zróżnicowano ze względu na wielkość miast (rycina 5.4). Najliczniej reprezentowana jest grupa miast o złej dostępności transportowej, do której należy 15 ośrodków małych i 4 średnie. Bardzo złą dostępnością charakteryzują się wyłącznie 4 małe miasta. Najlepiej dostępnymi w skali regionalnej ośrodkami do 20 tys. mieszkańców są Koluszki oraz Łask. Na uwagę zasługuje wysoka pozycja najmniejszego w województwie łódzkim Szadku. W grupie miast średnich wyraźnie dominują Zgierz i Pabianice, które wraz z czterema innymi ośrodkami osiągnęly poziom dobrej dostępności transportowej. Spośród wszystkich 44 ośrodków, podobnie jak w każdej z analizowanych sfer dostępności, najwyższy poziom osiągnęła Łódź.

Wprowadzenie do analizy holistycznej poziomu średniego wskazuje, że wyraźna większość miast województwa łódzkiego odznacza się ponadprzeciętnym poziomem dostępności w stosunku do wielkości ośrodka wyrażonej liczbą jego mieszkańców. Wyróżniającymi się pod tym względem jednostkami są Stryków oraz Szadek. W przypadku miast plasujących się poniżej średniej odległości od niej są znacznie mniejsze, a największą rozbieżnością charakteryzuje się Wieluń.

Relacja poziomu dostępności miast województwa łódzkiego do ich odległości topologicznej względem pozostałych ośrodków regionu w przypadku podejścia holistycznego nie jest tak wyraźna, jak ta dotycząca wielkości ośrodków.

Określenie dostępności miast województwa łódzkiego pod względem potencjalnym, w transporcie zbiorowym i indywidualnym, pozwoliło również na ich zakwalifikowanie do jednego z utworzonych typów ośrodków. Każdy z typów odnosi się do stopnia wykorzystania potencjału oraz rodzaju dominującego transportu. W taki sposób uzyskano sześć typów obejmujących miasta, których dostępność transportowa jest: 


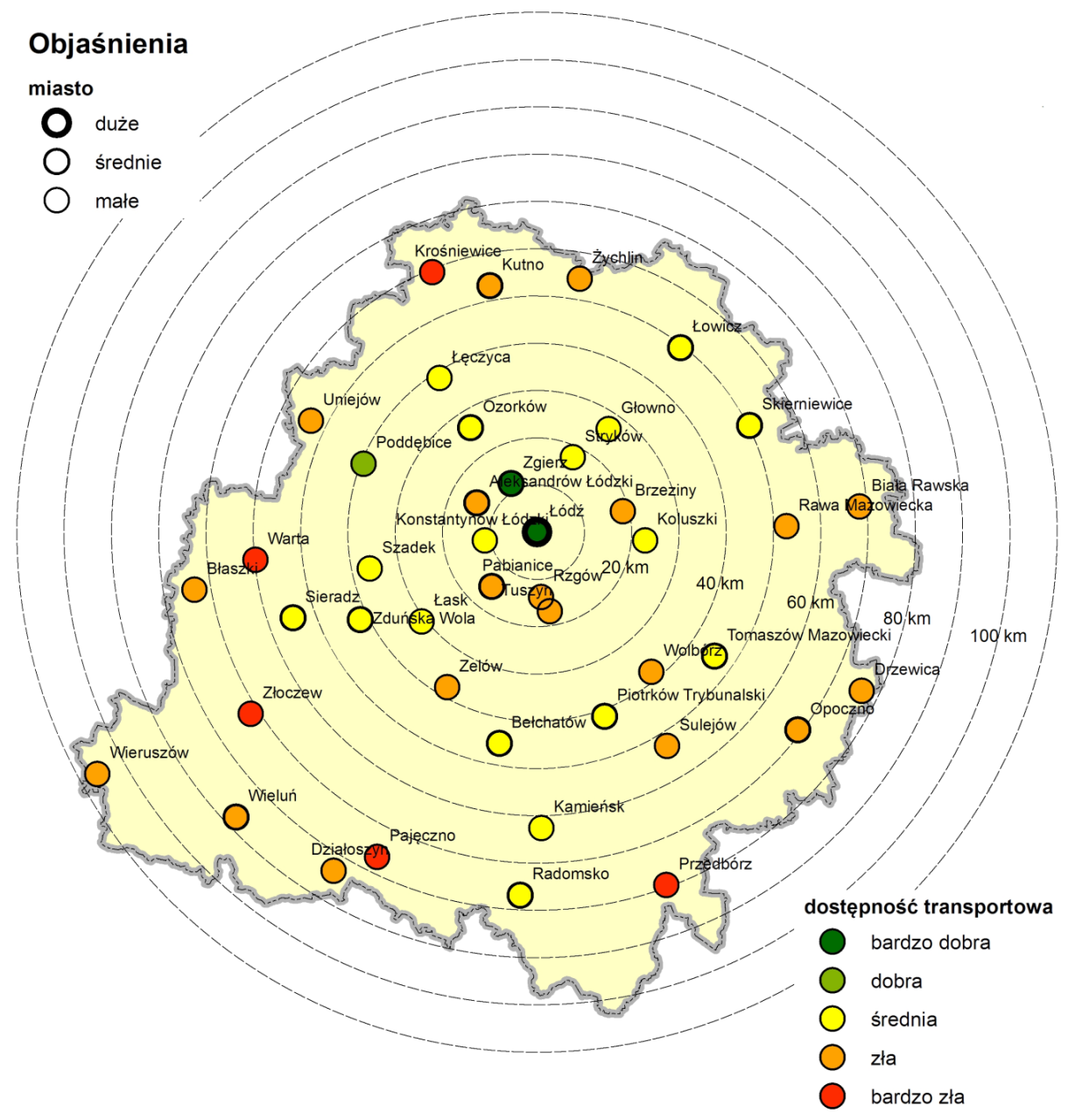

Rycina 5.4. Zróżnicowanie przestrzenne dostępności transportowej miast województwa łódzkiego względem ich wielkości i oddalenia od Łodzi

Źródło: opracowanie własne

I - oparta na transporcie indywidualnym,

II - oparta na transporcie indywidualnym z niewykorzystanym potencjałem,

III - zrównoważona z niewykorzystanym potencjałem,

IV - oparta na transporcie zbiorowym z niewykorzystanym potencjałem,

$\mathrm{V}$ - oparta na transporcie zbiorowym,

VI - zrównoważona.

Każde $\mathrm{z}$ miast zostało wpisane $\mathrm{w}$ obręb trójkąta równobocznego, którego każdy z boków reprezentuje jeden z trzech wymiarów dostępności zgodnie 
z uzyskaną punktacją. Uprzednio określono, jakim odsetkiem maksymalnej sumy punktów jest wynik uzyskany w każdym z wymiarów przez dane miasto. W zależności od odsetków uzyskanych przez każdy z ośrodków, lokalizowano je w jednym z sześciu obszarów wykresu odpowiadających poszczególnym typom miast zbliżonych do siebie pod względem cech dostępności transportowej (rycina 5.5).

Najliczniej reprezentowany jest typ miast, które najwyższe wyniki punktowe uzyskały w zakresie transportu zbiorowego. Nie są to jednak wyniki przystające do tych płynących z dostępności potencjalnej. Sytuację taką można interpretować jako niewykorzystane możliwości, wynikające ze stanu i układu infrastruktury, które przy odpowiednio efektywnie funkcjonującym transporcie zbiorowym mogą skutkować wzrostem poziomu dostępności ośrodków. Taką szansę posiadają: Tomaszów Mazowiecki, Zgierz, Skierniewice, Radomsko, Zduńska Wola, Sieradz, Łowicz, Opoczno, Ozorków, Wieluń, Głowno, Wieruszów, Drzewica oraz Błaszki. Swoje możliwości płynące z wyposażenia infrastrukturalnego wykorzystują natomiast w zakresie transportu zbiorowego Piotrków Trybunalski, Kutno oraz Żychlin. Dwanaście miast opiera swoją dostępność na transporcie indywidualnym, wykorzystując w pełni charakterystyczny dla nich potencjał. Sytuacja taka występuje w przypadku: Aleksandrowa Łódzkiego, Konstantynowa Łódzkiego, Brzezin, Zelowa, Tuszyna, Pajęczna, Sulejowa, Złoczewa, Rzgowa, Warty, Uniejowa oraz Wolborza.

Trzecią, co do liczebności, grupą miast o wysokim stopniu podobieństwa są jednostki, którym poziom dostępności w zakresie transportu indywidualnego przyniósł wysokie pozycje w rankingach. Nie są one jednak tak wysokie, jak wskazywałaby na to dostępność potencjalna. Do grupy tej należą: Pabianice, Bełchatów, Łask, Rawa Mazowiecka, Poddębice, Biała Rawska i Szadek. Natomiast Łęczycę, Koluszki, Działoszyn, Stryków i Kamieńsk charakteryzuje względna równowaga pomiędzy dostępnością wynikającą z funkcjonowania transportu zbiorowego i indywidualnego. Niemniej jednak ujęcie potencjałowe wskazuje, że ich poziom mógłby być wyższy. Relacja pomiędzy dostępnością w ujęciu potencjalnym, transportu zbiorowego i indywidualnego wskazuje na najkorzystniejszą sytuację w przypadku trzech ośrodków: Krośniewic, Przedborza oraz Łodzi. Wykorzystując charakterystyczne dla siebie możliwości, odznaczają się względnym zrównoważeniem pomiędzy transportem zbiorowym i indywidualnym.

Podejmując próbę wyjaśnienia przyczyn kształtujących poziom dostępności miast województwa łódzkiego, należy wskazać za Rosikiem (2012), że główną determinantą jest stan infrastruktury transportowej zarówno w ujęciu jakościowym, jak i ilościowym. $Z$ analizy zróżnicowania przestrzennego jednostek o poszczególnych poziomach dostępności wynika, że miasta o średniej, dobrej i bardzo dobrej dostępności zlokalizowane są na trasie przebiegu najważniejszych dróg transportu drogowego i kolejowego. Wyraźnie uwidacznia się krzyżowy układ północ-południe i wschód-zachód tożsamy dla przebiegu kluczowych elementów infrastruktury transportowej i grupy miast o wyższych poziomach dostępności. 


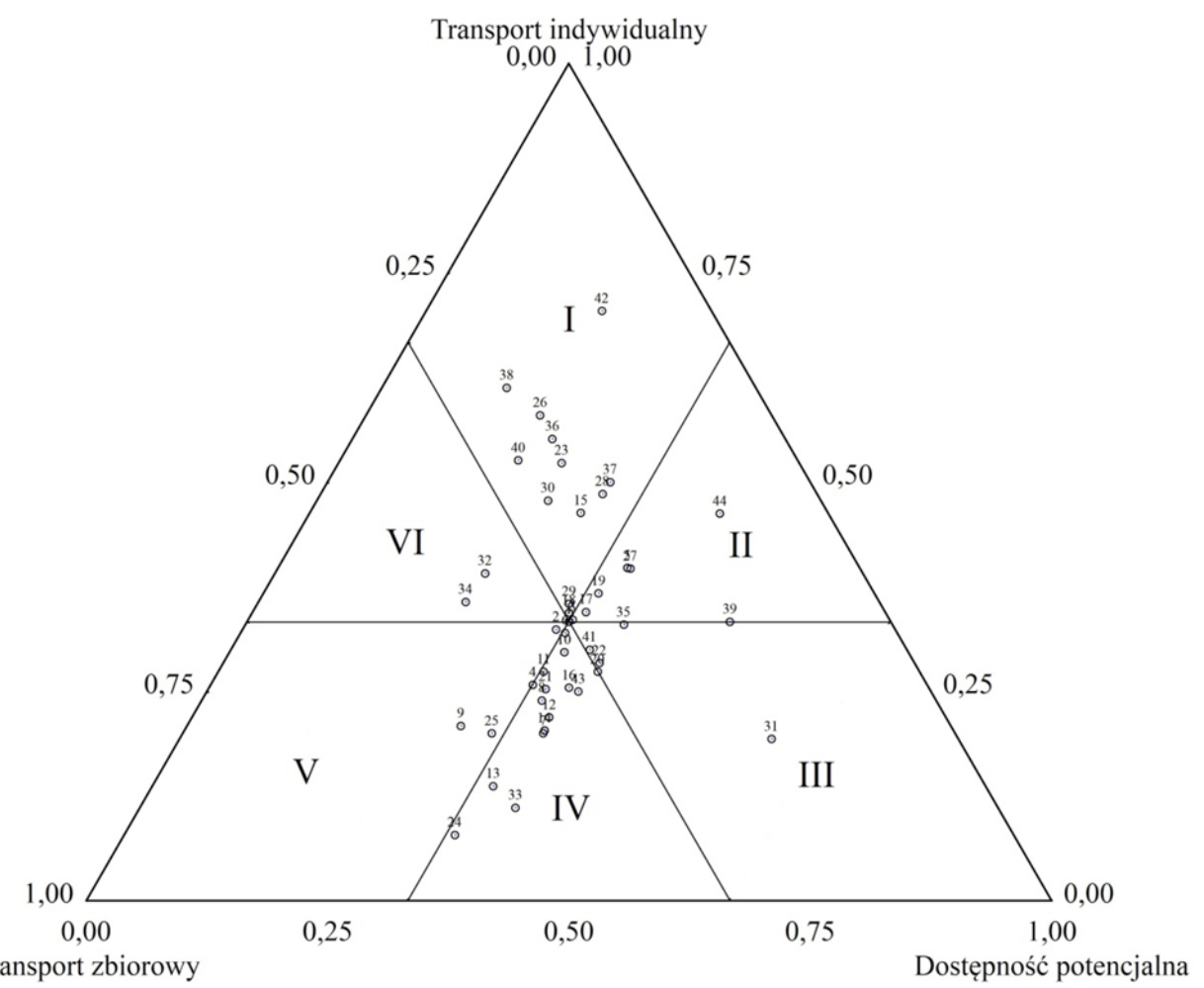

Rycina 5.5. Typologia miast województwa łódzkiego pod względem dostępności transportowej 1 - Łódź, 2 - Piotrków Trybunalski, 3 - Pabianice, 4 - Tomaszów Mazowiecki, 5 - Bełchatów, 6 - Zgierz, 7 - Skierniewice, 8 - Radomsko, 9 - Kutno, 10 - Zduńska Wola, 11 - Sieradz, 12 - Łowicz, 13 - Wieluń, 14 - Opoczno, 15 - Aleksandrów Łódzki, 16 - Ozorków, 17 - Łask, 18 - Konstantynów Łódzki, 19 - Rawa Mazowiecka, 20 - Łęczyca, 21 - Głowno, 22 - Koluszki, 23 - Brzeziny, 24 - Wieruszów, 25 - Żychlin, 26 - Zelów, 27 - Poddębice, 28 - Tuszyn, 29 - Pajęczno, 30 - Sulejów, 31 - Działoszyn, 32 - Krośniewice, 33 - Drzewica, 34 - Przedbórz, 35 - Stryków, 36 - Złoczew, 37 - Rzgów, 38 - Warta, 39 - Biała Rawska, 40 - Uniejów, 41 - Kamieńsk, 42 - Wolbórz, 43 - Błaszki, 44 - Szadek

Źródło: opracowanie własne

Potwierdzenie znajduje tu problematyczne znaczenie autostrad dla spójności regionu w zakresie transportu. Uniejów i Poddębice, pomimo bliskości węzłów na autostradzie A2, charakteryzują się zróżnicowanym poziomem dostępności - odpowiednio złym i dobrym. Ponadto Głowno i Łowicz, będąc w podobnym położeniu względem autostrady, mają dostępność na tym samym średnim poziomie. Również przebieg drogi ekspresowej S8 nie skutkuje bezpośrednio wzrostem dostępności. Przechodząc bezpośrednio przez Wolbórz i Rawę Mazowiecką, nie jest ona czynnikiem na tyle silnym, aby zniwelować odpowiednio słabo funkcjonują- 
cy transport zbiorowy i znaczne oddalenie od centrum regionu. Należy stwierdzić, iż o ile samo istnienie infrastruktury jest konieczne, o tyle jej jakość, przynajmniej w skali regionalnej, jest czynnikiem drugoplanowym. Przebieg ogólnodostępnych dróg krajowych wydaje się mieć znaczenie decydujące w zakresie infrastruktury drogowej. Przebieg linii kolejowych jest czynnikiem ważnym, ale nie koniecznym dla uzyskania wysokiej dostępności. Szadek czy Bełchatów nie są włączone w system pasażerskich połączeń kolejowych, a pomimo to ich dostępność kształtuje się na dobrym poziomie. Jest to z pewnością spowodowane, w przypadku Szadku, niewielkimi odległościami fizycznymi od centrum regionu, a Bełchatowa, przebiegiem głównych dróg z północy na południe regionu. Ze względu na znaczne ograniczenie przestrzenne sieci niewielkie znaczenie dla holistycznego poziomu dostępności mają funkcjonujące połączenia tramwajowe. Grupa pięciu miast obsługiwanych przez tramwaje wyróżnia się bardzo zróżnicowanym poziomem dostępności. Na szczególną uwagę zasługuje w tym względzie Konstantynów Łódzki. O ile w przypadku pozostałych czterech miast na poziom dostępności wpłynęło również funkcjonowanie połączeń kolejowych, o tyle w przypadku Konstantynowa alternatywą są wyłącznie połączenia drogowe, a pomimo to miasto charakteryzuje się dostępnością na średnim poziomie.

Wskazywana zależność poziomu dostępności ośrodka od jego wielkości, wyrażonej liczbą mieszkańców, znajduje potwierdzenie m.in. w przypadku Wielunia, Opoczna, Kutna oraz Aleksandrowa Łódzkiego, które jako jedyne spośród miast powyżej 20 tys. mieszkańców charakteryzują się złym poziomem dostępności. Pozostałe ośrodki nie osiągają poziomu niższego niż średni. Trzy pierwsze wskazane miasta doskonale obrazują wyraźną zależność oddalenia ośrodka od centrum regionu i jego poziomu dostępności. Opór przestrzeni jest czynnikiem przewyższającym atrakcyjność miejsca. Wagę czynnika wielkości ośrodka należy tłumaczyć dwojako. Po pierwsze, wielkość ośrodka jest ważnym argumentem przy prowadzeniu polityki inwestycyjnej w zakresie infrastruktury transportowej. Planowanie przebiegu danego odcinka drogi czy linii, poza spełnieniem nadrzędnego celu, jakim jest połączenie punktów w przestrzeni, uwzględnia m.in. bariery naturalne i jednostki osadnicze występujące na danym odcinku. Po drugie, ma ona odzwierciedlenie w organizacji transportu zbiorowego. Większe miasta stanowią większą bazę potencjalnych klientów dla organizatorów przewozów pasażerskich. Tego typu ośrodki charakteryzują się większą i bardziej intensywną codzienną migracją związaną m.in. z dojazdami do pracy. Skutkuje to szerszym i głębszym asortymentem oferowanych przewozów.

Wzmiankowana już rola odległości od centrum regionu uwidacznia się szczególnie w przypadku miast położonych poza wspomnianymi osiami północ-południe, wschód-zachód. Wyjątkiem są jedynie Krośniewice, w których na niski poziom dostępności wpływają dodatkowo brak połączeń kolejowych i słaba oferta samochodowego transportu zbiorowego. Określenie pełnej listy czynników warunkujących dostępność jest zadaniem wyjątkowo skomplikowanym. Wielość 
elementów, które należy włączyć do analizy, uwzględnienie etapu projektowania, implementacji oraz użytkowania infrastruktury transportowej, poszerzone dodatkowo o czynnik losowy, zmuszają do wprowadzania pewnych uogólnień.

Poza czynnikiem infrastrukturalnym pośredni wpływ na poziom dostępności transportowej miast województwa łódzkiego wywiera kreowana polityka transportowa i realizacja planowanych $\mathrm{w}$ niej inwestycji transportowych w zakresie sieci i taboru, ujętych w strategiach, planach czy programach. Jak podkreślano, w przypadku województwa łódzkiego czynnik ten ma szczególne znaczenie ze względu na jego położenie zarówno w krajowych, jak i międzynarodowych sieciach transportowych.

Ze względu na regionalną skalę badania, wpływ pozostałych czynników antropogenicznych nie różnicuje poziomu dostępności miast województwa. Również oddziaływanie elementów środowiska przyrodniczego województwa łódzkiego mających wpływ na dostępność jest ograniczone w zakresie realizacji transportu. Ich wpływ zarysowuje się głównie na etapie wdrażania infrastruktury transportowej. Nie jest to jednak oddziaływanie diametralnie zmieniające przebieg infrastruktury. Dla przykładu podać można sytuację Parku Krajobrazowego Wzniesień Łódzkich, którego powstanie możliwe było przy założeniu jego przyszłego „przecięcia” przez autostradę A1.

Różnice wysokości względnych wynikające z pionowego ukształtowania terenu województwa łódzkiego nie stanowią bariery dla funkcjonowania transportu. Zmuszają jedynie do stosowania zabiegów inżynieryjnych niwelujących negatywne oddziaływanie. Nie jest to jednak bariera uniemożliwiająca inwestycje i diametralnie zmieniająca stosunki transportowe regionu.

Również elementy sieci hydrograficznej województwa łódzkiego nie stanowią przeszkody dla realizacji transportu. Szerokość dolin największych rzek płynących przez region czy największe zbiorniki w postaci Zbiornika Sulejowskiego i Jeziorska nie stanowią przeszkód zaburzających dostępność poszczególnych ośrodków miejskich regionu, zmuszając jedynie do stosowania nieznacznych obejść.

$\mathrm{Na}$ terenie województwa łódzkiego, będącego regionem o najniższej lesistości w Polsce, nie występują również utrudnienia związane z wielkoobszarowymi skupiskami leśnymi, utrudniającymi znacząco trasowanie dróg czy linii kolejowych i późniejszą ich eksploatację.

Sumaryczne oddziaływanie czynników geologicznych, klimatyczno-pogodowych, ukształtowania powierzchni, sieci hydrograficznej oraz fauny i flory na zróżnicowanie dostępności transportowej miast województwa łódzkiego ma nieznaczny zakres i skupia się przede wszystkim na etapie planowania i implementacji infrastruktury. 


\section{WNIOSKI}

Dostępność transportowa, ujmowana jako wyznacznik możliwości osiągania danych punktów lub obszarów docelowych, stanowi jeden z najważniejszych czynników warunkujących poziom rozwoju społecznego i gospodarczego, przełamując przestrzenną, czasową i ekonomiczną dywergencję.

W opracowaniu dokonano wielopoziomowej analizy dostępności transportowej miast $\mathrm{w}$ województwie łódzkim. Jednocześnie w ramach prowadzonych rozważań skoncentrowano się na zbadaniu relacji zachodzących pomiędzy poziomem dostępności ośrodków miejskich a wyposażeniem infrastrukturalnym w zakresie transportu, funkcjonowaniem transportu zbiorowego i możliwościom realizacji samochodowego transportu indywidualnego. Na podstawie podjętych analiz można sformułować kilka wniosków. Oto one:

1. Dostępność transportowa miast w województwie łódzkim jest silnie uzależniona w pierwszej kolejności od wielkości ośrodków, a następnie od ich oddalenia od centrum regionu. Najniższym poziomem dostępności charakteryzują się jedynie ośrodki poniżej 20 tys. mieszkańców. Natomiast spośród wszystkich 28 małych miast jedynie Koluszki i Łask wyróżniają się średnim poziomem dostępności, będąc jednocześnie ośrodkami zlokalizowanymi blisko centrum regionu. Najliczniej reprezentowana jest grupa miast o złej dostępności transportowej, do której należą 4 średnie ośrodki.

2. Potencjalna dostępność transportowa miast województwa łódzkiego uzależniona jest również od ich wielkości, a następnie od topologicznej odległości pomiędzy ośrodkami.

3. Występuje wyraźna zależność pomiędzy spadkiem poziomu dostępności potencjalnej miast województwa łódzkiego wynikającej z ilości, jakości i przebiegu dróg a ich oddaleniem od centrum regionu.

4. Istniejący układ sieci drogowej w województwie łódzkim efektywnie łączy miasta regionu. Wszelkiego rodzaju działania nastawione na sieć drogową, mające na celu poprawę skomunikowania wzajemnego miast województwa poprzez nowe odcinki dróg, mogą przyczynić się jedynie do wzrostu wykorzystania potencjału w zakresie od 5 do $25 \%$.

5. Słabą stroną aktualnej sieci dróg w województwie łódzkim jest niezadowalający stan techniczny. Największy problem stanowi zniszczona nawierzchnia, 
niedopasowanie parametrów poszczególnych odcinków sieci do roli, jaką pełnią w całym układzie.

6. Występuje znaczna ilość niewykorzystanego potencjału w zakresie sieci kolejowej. Inwestycje w tworzenie nowych linii pomiędzy miastami województwa łódzkiego mogłyby przynieść znaczny wzrost efektywności funkcjonowania połączeń kolejowych.

7. Łódź stanowi istotną barierę dla realizacji połączeń kolejowych w ujęciu regionalnym. Zaburzenia wynikają z wykorzystywania linii przez pociągi podmiejskie i dalekobieżne. Łódź dzieli również sieć krajowych połączeń na dwie części obsługiwane przez dwa dworce. Utrudnia to włączanie kolei do wewnętrznej obsługi komunikacyjnej województwa.

8. Dostępność transportowa miast województwa łódzkiego wynikająca z funkcjonowania zbiorowego transportu samochodowego, kolejowego i tramwajowego jest wyraźnie uwarunkowana liczbą potencjalnych użytkowników. Lokalizacja miasta w sieci osadniczej i regionie jest czynnikiem wtórnym.

9. Organizacja transportu zbiorowego, chociaż w poszczególnych częściach województwa łódzkiego charakteryzuje się różną efektywnością działania, to zapewnia przynajmniej w minimalnym stopniu spójność wszystkich 44 miast regionu.

10. Funkcjonujący pomiędzy miastami województwa łódzkiego transport zbiorowy nie odpowiada możliwościom wynikającym z ze stanu i układu infrastruktury. Efektywnie zarządzany transport zbiorowy może przyczynić się do wzrostu poziomu dostępności ośrodków.

11. Poziom dostępności miast połączonych siecią kolejową uwarunkowany jest wielkością ośrodka. Jest to jednak zależność znacznie słabsza niż ta dotycząca transportu samochodowego.

12. Czynnikiem determinującym dostępność miast w ujęciu samochodowego transportu indywidualnego jest odległość, a nie stan infrastruktury. Akceptowalne czasy przejazdów występują pomiędzy ośrodkami położonymi najbliżej siebie. Najwięcej relacji o czasie przejazdu do godziny możliwych jest do miast położonych w centrum województwa, w granicach Łódzkiego Obszaru Metropolitalnego.

Przedstawione wnioski mogą służyć jako wskazówka do poprawnego zarządzania, kierowania rozwojem infrastruktury transportowej oraz organizacją transportu zbiorowego na poziomie regionalnym. 


\section{BIBLIOGRAFIA}

Accessibilité des territories et des services. Notions et representation, 2008, Setra, [online] http:// www.setra.equipement.gouv.fr/Accessibilite-des-territoires-et.html.

Adamski A., 2003, Inteligentne systemy transportowe: sterowanie, nadzór i zarządzanie, AGH Uczelniane Wydawnictwa Naukowo-Dydaktyczne, Katowice.

AutoMapa Polski 6.14a 13.

Bank Danych Lokalnych, Główny Urząd Statystyczny, [online] http://www.stat.gov.pl/bdl/app/strona.html?p_name $=$ indeks.

Baradaran S., Ramjerdi F., 2001, Performance of Accessibility Measures in Europe, „Journal of Transportation and Statistics", vol. 4 (2-3), s. 31-48.

Bartczak A., Żylicz T., 2005, Dylematy rozwoju transportu w świetle strategii lizbońskiej, „Transport Miejski i Regionalny", nr 1, s. 2-8.

Bartosiewicz B., Marszał T., 2011, Zróżnicowanie przestrzenne dostępności miast i gmin w województwie łódzkim w świetle sieci transportu zbiorowego, oprac. na zlecenie Biura Planowania Przestrzennego Województwa Łódzkiego.

Bartosiewicz B., Pielesiak I., 2012, Powiązania transportowe w Lódzkim Obszarze Metropolitalnym, [w:] Bartosiewicz B., Marszał T., Pielesiak I. (red.), Spójność terytorialna Łódzkiego Obszaru Metropolitalnego, „Studia KPZK PAN”, t. 147, s. 105-137.

Baza informacji o sieci kolejowej, [online] http://www.bazakolejowa.pl/.

Berezowski S., 1975, Zarys geografii komunikacji, PWN, Warszawa.

Biała księga. Plan utworzenia jednolitego europejskiego obszaru transportu-dażenie do osiagnięcia konkurencyjnego i zasobooszczędnego systemu transportu, 2011, COM (2011), 144 wersja ostateczna.

Bruinsma F.R., Rietveld P., 1998, The Accessibility of European Cities: Theoretical Framework and Comparison of Approaches, „Environment and Planning”, vol. 30 (3), s. 499-521.

Brzeziński A., 1999, Ruch na drogach szybkiego ruchu w otoczeniu miast, cz. I - metoda analiz, „Transport Miejski”, nr 2, s. 181-203.

Cauvin C., 2005, A Systemic Approach to Transport Accessibility. A Methodology Developed in Strasbourg: 1982-2002, „European Journal of Geography”, [online] http://cybergeo.revues. org/index3425.html?lang=en.

Chojnicki Z., 1966, Zastosowanie modeli grawitacji i potencjału w badaniach przestrzenno-ekonomicznych, „Studia KPZK PAN”, t. 14, Warszawa.

Christaller, W., 1963, Some Considerations of Tourism Location in Europe, Paper of the Regional Science Association, no. 12, s. 95-105.

Czyż T., 2002, Application of the Potential Model to the Analysis of Regional Differences in Poland, „Geographia Polonica”, vol. 75 (1), s. 13-24.

Dalvi M.Q., Martin K.M., 1976, The Measurement of Accessibility: Some Preliminary Results, „Transportation”, no. 5, s. 17-42. 
Decyzja Parlamentu Europejskiej i Rady nr 661/UE z dnia 7 lipca 2010 r. w sprawie unijnych wytycznych dotyczacych rozwoju Transeuropejskiej Sieci Transportowej, 2010, „Dziennik Urzędowy Unii Europejskiej”, nr L 204 z 5 sierpnia.

Diagnoza polskiego transportu - stan w 2009 roku, 2011, załącznik 1 do Strategii rozwoju transpor$t \mathrm{u}$, Ministerstwo Infrastruktury, Warszawa.

Diagnoza województwa łódzkiego, 2005, t. III: Sfera funkcjonalno-przestrzenna, Łódź, [online] http://www.lodzkie.pl/wps/wcm/connect/bip/bip/urzadmarszalkowski/programy/strategiawojewodztwalodzkiego/tom_iii_sfera_funkcjonalno_-przestrzenna.zip.

Domańska A., 2006, Wpływ infrastruktury transportu drogowego na rozwój regionalny, Wydawnictwo Naukowe PWN, Warszawa.

Domański R., 1979, Accessibility, Efficiency and Spatial Organization, „Environment and Planning A", vol. 11 (10), s. 1189-1206.

Domański R., 1980, Dostępność, efektywność i przestrzenna organizacja, „Przegląd Geograficzny”, vol. 52 (1), s. 3-39.

Domański R., 1990, Gospodarka przestrzenna, PWN, Warszawa.

ESPON, 2002, Project 1.2.1: Transport Services and Networks Territorial Trends and Basic Supply of Infrastructure for Territorial Cohesion. First Interim Report, [online] http://www.espon.eu/ export/sites/default/Documents/Projects/ESPON2006Projects/ThematicProjects/TransportTrends/1.ir_1.2.1.pdf.

ESPON, 2004, Project 1.2.1: Transport Services and Networks: Territorial Trends and Basic Supply of Infrastructure for Territorial Cohesion, Project Report, [online] http://www.espon.eu/ export/sites/default/Documents/Projects/ESPON2006Projects/ThematicProjects/TransportTrends/fr-1.2.1-full.pdf.

Feltynowski M., 2009, Dostęność komunikacyjna jako element rozwoju gmin wiejskich w Łódzkim Obszarze Metropolitarnym, [w:] Infrastruktura i ekologia obszarów wiejskich, nr 6, Polska Akademia Nauk, Kraków, s. 197-207.

Gaca S., Suchorzewski W., Tracz M., 2008, Inżynieria ruchu drogowego. Teoria i praktyka, WKit, Warszawa.

Gadziński J., 2010, Ocena dostępności komunikacyjnej przestrzeni miejskiej na przykładzie Poznania, „Biuletyn IGSE i GP UWAM”, Seria Rozwój Regionalny i Polityka Regionalna, nr 13.

Generalny Pomiar Ruchu 2010, [online] http://www.gddkia.gov.pl/p1/987/gpr-2010.

Geoportal, [online] http://mapy.geoportal.gov.pl/imap/?gpmap=gp0\&actions=acShowWgPlot.

Geurs K.T., Ritsema van Eck J.R., 2001, Accessibility Measures: Review and Applications, RIVM report 408505 006, National Institute of Public Health and the Environment, Bilthoven.

Gęsiarz Z., 1982, Zarys geografii transportu, WSiP, Warszawa.

Google Earth, wersja 7.1.2.2041.

Google Maps, [online] http://support.google.com/maps/bin/answer.py?hl=en\&answer=61455.

Gould P., 1969, Spatial Diffusion, Resource Paper, no. 17, Association of American Geographers, Washington.

Grzywacz W., 1982, Infrastruktura transportu, WKiŁ, Warszawa.

Guzik R., 2003, Przestrzenna dostępność szkolnictwa ponadpodstawowego, Instytut Geografii i Gospodarki Przestrzennej UJ, Kraków.

Guzik R., 2011, Dostępność komunikacyjna wybranych miast Małopolski 2011-2020, oprac. na zlecenie Departamentu Polityki Regionalnej Urzędu Marszałkowskiego Województwa Małopolskiego, Instytut Geografii i Gospodarki Przestrzennej UJ, Kraków.

Handy S.L., Niemeier D.A., 1997, Measuring Accessibility: an Exploration of Issues and Alternative, „Environment and Planning A, no. 29, s. 1175-1194.

Hansen W.G., 1959, How Accessibility Shapes Land-use, „Journal of the American Institute of Planners", no. 25, s. 73-76. 
Helliwell J.F., Schembri L.L., 2005, Borders, Common Currencies, Trade and Welfare: What Can We Learn from the Evidence?, „Bank of Canada Review”, Spring, s. 19-33.

Highway Capacity Manual, 2000, Transportation Research Board, Washington.

Hildebrandt A., Nowicki M., Susmarski P. (2010), Atrakcyjność inwestycyjna województw i podregionów Polski, Instytut Badań nad Gospodarką Rynkową, Gdańsk.

Identyfikacja i delimitacja obszarów problemowych i strategicznych interwencji $w$ Polsce. Wnioski z Analiz, 2009, Ministerstwo Rozwoju Regionalnego, Instytut Badań i Rozwoju, Warszawa, 2009.

Ilustrowany stownik statystyk transportu, b.r.w., Europejska Komisja Gospodarcza, Eurostat, Międzynarodowe Forum Transportu, [online] http://ec.europa.eu/eurostat/ramon/coded files/ transport glossary 4 ed PL.pdf.

Ingram D.R., 1971, The Concept of Accessibility: a Search for an Operational Form, „, Regional Studies", no. 5, s. 101-107.

Instrukcja oceny efektywności ekonomicznej przedsięwzięć drogowych i mostowych dla dróg wojewódzkich, 2008, Instytut Badawczy Dróg i Mostów, Warszawa.

Isard W., 1954, Location Theory and Trade Theory: Short-Run Analysis, „Quarterly Journal of Economics", vol. 68 (1), s. 305-322.

Jakubowski J., 1976, Motoryzacja i ochrona środowiska, WKiŁ, Warszawa.

Janecki R., Krawiec S., 2009, Problemy dostęności przestrzennej we wspótczesnej polityce transportowej, „Transport Miejski i Regionalny”, nr 1, s. 2-12.

Kansky K.J., 1963, Structure of Transport Network: Relationships between Network Geometry and Regional Characteristics, „Research Papers”, no. 84, University of Chicago.

Karlqvist A., 1975, Some Theoretical Aspects of Accessibility-based Location Models, [w:] Karlqvist A., Lundqvist L., Snickars F. (eds.), Dynamic Allocation of Urban Space, Saxon House, Lexington, Farnborough.

Kolarski A., 1976, Funkcje rozkładu jazdy w transporcie pasażerskim, „Problemy Ekonomii Transportu", nr 2, s. 51-67.

Komornicki T., 1999, Granice Polski. Analiza zmian przenikalności w latach 1990-1996, „Geopolitical Studies", nr 5, IGiPZ PAN, Warszawa.

Komornicki T., 2007, Rola infrastruktury transportowej w rozwoju kraju - wyzwania wobec kohezji przestrzennej, [w:] Markowski T., Stasiak A. (red.), Rola polskiej przestrzeni w integrujacej się Europie, „Biuletyn KPZK PAN”, nr 233, s. 63-86.

Komornicki T., 2009, Polska polityka transportowa wobec prognozowanych zmian klimatycznych, „Studia KPZK PAN”, t. 74, s. 75-87.

Komornicki T., Rosik P., Stępniak M., 2011, Dostępność transportowa w Polsce wschodniej, oprac. na zlecenie Ministerstwa Rozwoju Regionalnego.

Komornicki T., Śleszyński P., Pomianowski W., Rosik P., Siłka P., Stępniak M., 2008, Opracowanie metodologii liczenia wskaźnika międzygatęziowej dostępności transportowej terytorium Polski oraz jego oszacowanie, oprac. dla Ministerstwa Rozwoju Regionalnego, IGiPZ PAN, Warszawa.

Komornicki T., Śleszyński P., Rosik P., Pomianowski W., 2009, Dostępność przestrzenna jako przestanka ksztaltowania polskiej polityki transportowej, „Biuletyn KPZK PAN”, nr 241.

Komunikat Komisji do Parlamentu Europejskiego, Rady, Trybunału Sprawiedliwości, Trybunału Obrachunkowego, Europejskiego Banku Inwestycyjnego, Europejskiego Komitetu Ekonomiczno-Społecznego i Komitetu Regionów z dnia 19 października 2011 r. Pakiet na rzecz rozwoju zintegrowanych infrastruktur europejskich, 2011, COM/2011/676, Bruksela.

Koncepcja przestrzennego zagospodarowania kraju 2030, 2012, Ministerstwo Rozwoju Regionalnego, Warszawa. 
Kowalski M., Wiśniewski S., 2013, Ocena możliwości realizacji transportu zbiorowego przez miejskie przedsiębiorstwo komunikacyjne w Łodzi na terenie ksztattującego się Łódzkiego Obszaru Metropolitalnego, „Transport Miejski i Regionalny”, nr 3, s. 26-32.

Krajowa strategia rozwoju regionalnego 2010-2020: regiony, miasta, obszary wiejskie, 2010, Załączniki, Ministerstwo Rozwoju Regionalnego, Warszawa, [online] http://www.mir.gov.pl/ministerstwo/prawo/obowiazujace prawo/Documents/M20110423.pdf.

Kręgielewski R., 1979, Wplyw transportu na środowisko. Ocena ekonomiczna, WKi乇, Warszawa.

Kudłacz T., 1981, Zastosowanie metod grawitacji i grafów do hierarchizacji jednostek przestrzennych, „Przegląd Geograficzny”, t. 53 (3), s. 519-534.

Kulesza M., Koter M., 1998, Ksztattowanie się sieci miast na obszarze Polski Środkowej, [w:] Werwicki A. (red.), Transformacja społeczno-ekonomiczna Polski Środkowej, Wydawnictwo Uniwersytetu Łódzkiego, Łódź, s. 17-37.

Leszczycki S., 1971, Problemy środowiska czlowieka, „Biuletyn KPZK PAN”, nr 68.

Lijewski T., 1986, Geografia transportu Polski, PWE, Warszawa.

Lijewski T., 2000, Problemy zagospodarowania przestrzennego Polski w świetle przebudowy infrastruktury komunikacyjnej, „Dokumentacja Geograficzna IGiPZ PAN”, 18.

Liszewski S., 1965, Rozwój sieci drogowej województwa tódzkiego w okresie od 1770 do 1963 r., „Kwartalnik Historii Kultury Materialnej”, 13 (2).

Loose W., 2001, Flächennutzungsplan 2010 Freiburg - Stellungnahme zu den verkehrlichen Auswirkungen, Öko-Institut e.V., Freiburg.

Madeyski M., Lissowska E., Morawski W., 1975, Transport. Rozwój i integracja. WKiŁ, Warszawa.

Majewski J., 2002, Współczesna sieć połaczeń kolejowych w przestrzeni Polski, „Prace Komisji Geografii Komunikacji PTG”, t. 8, s. 181-198.

Majewski B., Beim M., 2008, Dostępność komunikacji publicznej w Poznaniu, [w:] Czyż T., Stryjakiewicz T., Churski P., (red.), Nowe kierunki i metody w analizie regionalnej, „Biuletyn IGSE i GP UAM", Seria Rozwój Regionalny i Polityka Regionalna, nr 3, s.115-124.

Maleczyński K., 1926, Najstarsze targi w Polsce i stosunek ich do miast przed kolonizacja na prawie niemieckim, Lwów.

Mapa stanu budowy dróg w województwie łódzkim, [online] http://www.gddkia.gov.pl/mapa-stanu-budowy-drog_lodzkie.

Massel A., 2008, Linia dużych prędkości Wrocław/Poznań-Lódź-Warszawa, „Technika Transportu Szynowego", nr 12, s. 36-41.

Master plan dla transportu kolejowego w Polsce do 2030 r., 2008, Ministerstwo Infrastruktury, Warszawa.

Mazur E., 1985, Wpływ transportu na degradację ziemi, „Przegląd Komunikacyjny”, nr 8, s. 164183.

Mazur E., 1998, Transport a środowisko przyrodnicze Polski, Wydawnictwo Naukowe Uniwersytetu Szczecińskiego, Szczecin.

Michalski L., 2010, Koncepcja ogólna Zintegrowanego Systemu Bezpieczeństwa Transportu, [w:] Krystek r. (red.), Zintegrowany System Bezpieczeństwa Transportu: Koncepcja Zintegrowanego Systemu Bezpieczeństwa Transportu w Polsce, t. III, WKiŁ, Warszawa.

Miller H.J., 1999, Measuring Space-time Accessibility Benefits within Transportation Networks: Basic Theory and Computational Procedures, „Geographical Analysis”, vol. 31 (2), s. 187-212.

Miszewska B., 1988, Problem peryferii w geografi - przykłady niwelowania dysproporcji, „Czasopismo Geograficzne", 59 (3), s. 257-266.

Napierała T., Adamiak M., Wiśniewski S., 2013, Interoperacyjność centrów logistycznych w regionie łódzkim, Urząd Miasta, Łódź. 
Narodowe strategiczne ramy odniesienia 2007-2013 wspierajace wzrost gospodarczy i zatrudnienie (NSRO). Narodowa strategia spójności, 2007, Ministerstwo Rozwoju Regionalnego, Warszawa.

Neutens T., Schwanen T., Witlox F., de Maeyer P., 2008, My Space or Your Space? Towards a Measure of Joint Accessibility, „Computers, Environment and Urban Systems”, no. 32, s. 331-342.

Nowicki M. (red.), 2010, Atrakcyjność inwestycyjna województw i podregionów Polski, Instytut Badań nad Gospodarką Rynkową, Gdańsk.

OpenStreetMap Polska, [online] http://openstreetmap.org.pl/osm/.

Opoczyński K., 2009, Wytyczne organizacji i przeprowadzenia Generalnego Pomiaru Ruchu w 2010 roku na drogach krajowych, Załącznik do Zarządzenia nr 59 Generalnego Dyrektora Dróg Krajowych i Autostrad z dnia 12/10/2009, GDDKiA, Warszawa.

Opoczyński K., Synteza wyników GPR 2010 [online] http://www.gddkia.gov.pl/userfiles/articles/g/ GENERALNY_POMIAR_RUCHU_2010/0.1.1.5_Synteza_GPR_2010.pdf.

Ord J. K., 1967, On a System of Discrete Distribution, „Biometrika”, vol. 54 (3-4), s. 649-656.

Paczkowski K., Budler M., 2012, Funkcjonowanie transportu zbiorowego w Eódzkim Obszarze Metropolitalnym - wstępne analizy, BPPWŁ, Łódź.

Paturalska-Nowak E., 2011, Analiza pomiaru ruchu w 2010 r. w województwie łódzkim, BPPWŁ, Łódź.

Pielesiak I., 2012, Spójność terytorialna Łódzkiego Obszaru Metropolitalnego w świetle powiązań infrastrukturalnych, praca doktorska, Wydział Nauk Geograficznych, UŁ, Łódź.

Pięciński W., 1977, Komunikacja jako czynnik ksztattowania miasta, „Miasto”, nr 1, s. 13-18.

Plan zagospodarowania przestrzennego województwa łódzkiego. Aktualizacja, Biuro Planowania Przestrzennego Województwa Łódzkiego, Łódź, 2010.

Polityka spójności 2014-2020. Inwestycje w rozwój gospodarczy $i$ wzrost zatrudnienia, 2011, Komisja Europejska, Dyrekcja Generalna ds. Polityki Regionalnej, [online] http://ec.europa.eu/ inforegio.

Polityka transportowa państwa na lata 2006-2025, 2005, Ministerstwo Infrastruktury, Warszawa.

Polska 2030 - wyzwania rozwojowe, 2009, Kancelaria Prezesa Rady Ministrów, Warszawa.

Polska 2030. Trzecia fala nowoczesności. Dlugookresowa strategia rozwoju kraju, 2013, Ministerstwo Administracji i Cyfryzacji, Warszawa.

Potrykowski M., 1980, Modele grawitacji i potencjału w badaniach przestrzenno-transportowych, [w:] Potrykowski M., Taylor Z., Metody ilościowe i modele w geografii transportu, „Przegląd Zagranicznej Literatury Geograficznej”, nr 4, s. 121-139.

Potrykowski M., Taylor Z., 1982, Geografia transportu. Zarys problemów, modeli i metod badawczych, PWN, Warszawa.

Powęska H., 1990, Dostępność przestrzenna usług medycznych a zachowania medyczne ludności, „Biuletyn Informacyjny IGiPZ PAN”, nr 61.

Prihar Z., 1965, Topological Properties of Telecommunications Networks, Proceeding of Institute of Radio Engineering, no. 44, s. 927-933.

Prognozy wskaźnika wzrostu PKB na okres 2008-2040, [online] https://www.gddkia.gov.pl/userfiles/articles/p/pismo-przewodnie-z-dnia-15032007_4423/Zalacznik_3_Prognozy_wzrostu_ PKB_200840_poprawa_kodow_nts.pdf.

Program budowy dróg krajowych na lata 2011-2015, 2011, Załącznik do uchwały Rady Ministrów nr 10/2011 z dnia 25 stycznia 2011 r., Ministerstwo Infrastruktury, Warszawa.

Program budowy i uruchomienia przewozów kolejami dużych prędkości w Polsce, 2008, Międzyresortowy Zespół ds. Kolei Dużych Prędkości, Ministerstwo Infrastruktury, Warszawa.

Przypływy ludności zwiąane z zatrudnieniem w Polsce w 2006 r., [online] http://www.stat.gov.pl/ gus/5840_13474_PLK_HTML.htm. 
Raport wprowadzajacy Ministerstwa Rozwoju Regionalnego na potrzeby przygotowania Przegladu OECD krajowej polityki miejskiej w Polsce. Część I: Diagnoza stanu polskich miast, 2010, Ministerstwo Rozwoju Regionalnego, Departament Koordynacji Polityki Strukturalnej, Warszawa.

Ratajczak W., 1977, Metody grafowe w geografii ekonomicznej, [w:] Chojnicki Z. (red.), Metody ilościowe i modele w geografii, PWN, Warszawa, s. 143-157.

Ratajczak W., 1980, Analiza i modele wpływu czynników społeczno-gospodarczych na kształtowanie się sieci transportowej, PWN, Warszawa-Poznań.

Ratajczak W., 1992, Dostępność komunikacyjna miast wojewódzkich Polski w latach 1948-1988, [w:] Chojnicki Z., Czyż T. (red.), Współczesne problemy geografii społeczno-ekonomicznej Polski, Wydawnictwo Naukowe Uniwersytetu Adama Mickiewicza, Poznań, s. 173-203.

Ratajczak W., 1999, Modelowanie sieci transportowych, Bogucki Wydawnictwo Naukowe, Poznań.

Regionalny program operacyjny województwa tódzkiego na lata 2007-2013, 2011, Łódź, [online] http://www.rpo.lodzkie.pl/wps/wcm/connect/a5a7e1804ad500fcaeb2ee0329bf70d0/RPO_ WL_20_03_2012.pdf?MOD=AJPERES.

Regionalna strategia innowacji dla województwa łódzkiego - LORIS 2030, 2013, Deloitte Business Consulting, ŁARR, Łódź.

Rosik P., 2008, Zróżnicowanie dostępności drogowej regionów Polski, „Transport Miejski i Regionalny", nr 5, s. -8 .

Rosik P., 2012, Dostępność lądowa przestrzeni Polski w wymiarze europejskim, „Prace Geograficzne", 233.

Rosik P., Komornicki T., Stępniak M., Pomianowski W.,2012, Oceny wplywu projektów drogowych realizowanych $w$ ramach Regionalnych Programów Operacyjnych na zwiększenie dostępności transportowej województw, Ministerstwo Rozwoju Regionalnego, Warszawa.

Rosik P., Pomianowski W., Stępniak M., Komornicki T., Śleszyński P., 2011, Narzędzie ewaluacyjno-badawcze dostępności transportowej gmin w podukładach wojewódzkich. Raport końcowy, IGiPZ PAN, Warszawa.

Rosik P., Stępniak M., Komornicki T., Pomianowski W., 2012, Monitoring spójności terytorialnej gmin w skali krajowej i międzynarodowej w latach 1995-2030, IGiPZ PAN, Warszawa.

Rosik P., Śleszyński P., 2009, Wpływ zaludnienia w otoczeniu drogi, ukształtowania powierzchni terenu oraz natężenia ruchu na średnia prędkość jazdy samochodem osobowym, „Transport Miejski i Regionalny", nr 10, s. 26-31.

Rosin R., 1971, Miasta regionu łódzkiego. Próba periodyzacji dziejów, „Region Łódzki. Studia i Materiały", t. 1.

Rozporzadzenie Ministerstwa Infrastruktury z 14 czerwca 2011 r. w sprawie stawek oplat za przejazd autostrada, 2011, Dz.U., nr 124, poz. 706.

Rozporzadzanie Ministra Transportu i Gospodarki Morskiej z dnia 10 września 1998 r. w sprawie warunków technicznych, jakim powinny odpowiadać budowle kolejowe i ich usytuowanie, 1998, Dz.U., nr 151, poz. 987.

Rozporzadzenie Ministra Transportu i Gospodarki Morskiej z dnia 2 marca 1999 r. w sprawie warunków technicznych, jakim powinny odpowiadać drogi publiczne i ich usytuowanie, 1999, Dz.U., nr 43, poz. 430.

Runge J., 2007, Metody badań w geografii społeczno-ekonomicznej-elementy metodologii, wybrane narzędzia badawcze, Wydawnictwo Uniwersytetu Śląskiego, Katowice.

Shiele M., 1998, Sieć transportowa regionu Polski Środkowej, [w:] Werwicki A. (red.), Transformacja społeczno-ekonomiczna Polski Środkowej, Wydawnictwo Uniwersytetu Łódzkiego, Łódź, s. $17-37$.

Shimbel A., 1953, Structural Properties of Communication Networks, „Bulletin of Mathematical Biophysics", no. 15, s. 501-507. 
Sierpiński G., 2010, Miary dostępności transportowej miast i regionów, „Zeszyty Naukowe Politechniki Śląskiej”, Transport, z. 66, s. 91-96.

Sobczyk W., 1985, Dostępność komunikacyjna w układach osadniczych miast, PWN, Warszawa.

Sobczyński M., 2005, Europejskie uzasadnienie przebiegu autostrady A-1, [w:] Autostrada A-1 i łódzki węzet komunikacyjny - drogi integrujace Polskę,17 listopada 2004. w Łodzi. Materiaty konferencyjne, Wydział Strategii i Analiz Urzędu Miasta Łodzi, Stowarzyszenie Miast Autostrady Bursztynowej, Łódź.

Spatial Simulation for the Social Sciences, [online] http://www.spatial-modelling.info/Darcy-2-module-de-comparaison.

Spiekermann K., Neubauer J., 2002, European Accessibility and Peripherality: Concepts, Models and Indicators, Nordregio Working Paper, Stockholm.

Strategia dla transportu kolejowego, 2007, Ministerstwo Transportu, Warszawa.

Strategia rozwoju kraju 2007-2015, 2006, Ministerstwo Rozwoju Regionalnego, Warszawa.

Strategia rozwoju kraju 2020. Aktywne społeczeństwo, konkurencyjna gospodarka, sprawne państwo, 2012, Ministerstwo Rozwoju Regionalnego.

Strategia rozwoju transportu do 2020 roku z perspektywa do 2030 roku, 2011, Ministerstwo Infrastruktury, Warszawa.

Strategia rozwoju województwa łódzkiego 2020, 2013, Biuro Planowania Przestrzennego Województwa Łódzkiego, Łódź.

Stutz F.P., 1973, Accessibility and the Effect of Scalar Variation on the Powered Transportation Connection Matrix, „Geographical Analysis”, vol. 5 (1), s. 61-66.

Suliborski A., Walkiewicz D., Wójcik M., 2009, Atlas Miasta Łodzi. Plansza L: Dostępność komunikacyjna Łodzi, http://www.mapa.lodz.pl/atlas/pdf/sup/Plansza_50R.pdf.

System Oceny Stanu Nawierzchni-SONS, 2010, Wytyczne stosowania. Aktualizacja zwiazana z wykorzystaniem wyników pomiarów ugięć nawierzchni. Załacznik do zarządzenia $\mathrm{nr} 5 \mathrm{z}$ dnia 01.02.2010 r., GDDKiA, [online] http://www.gddkia.gov.pl/userfiles/articles/s/system-oceny-stanu-nawierzchni_6165//documents/ktualizacja-wytycznych-sosn-o-pomugiec.pdf.

Śleszyński P., 2009a, Dostępność metropolii jako warunek konkurencyjności polskiej przestrzeni, „Mazowsze Studia Regionalne”, nr 2, s. 53-71.

Śleszyński P., 2009b, Rozwój nowoczesnej drogowej sieci transportowej a efektywność połaczeń głównych ośrodków miejskich (1989-2015), „Magazyn Autostrady”, nr 7, s. 50-53.

Taylor Z., 1974, Zastosowanie metod grafowych w badaniach przestrzenno-ekonomicznych, „Czasopismo Geograficzne", t. 45, s. 337-347.

Taylor Z., 1975, Charakterystyka zmian w strukturze sieci transportowych w ujęciu grafowym, „Przegląd Geograficzny”, t. 47 (3), s. 501-517.

Taylor Z., 1979, Przestrzenna dostęnność miejskiego systemu transportowego na przykładzie Poznania, „Studia KPZK PAN”, t. 67.

Taylor Z., 1980, O społecznej geografii transportu, „Przegląd Geograficzny”, t. 52 (1), s. 41-59.

Taylor Z., 1999, Przestrzenna dostępność miejsc zatrudnienia, kształcenia i usług a codzienna ruchliwość ludności wiejskiej, „Prace Geograficzne”, t. 171.

Taylor Z., 2007, Rozwój i regres sieci kolejowej w Polsce, IGiPZ PAN Monografie, t. 7, Warszawa. Tylutki A., 1975, Materiałochtonność produkcji transportowej, „Prace OBET”, nr 259.

Update of Selected Potential Accessibility Indicators. Final Report. February 2007. Spiekermann \& Wegener. Urban and Regional Research (S\&W), RRG Spatial Planning and Geoinformation, [online] http://www.espon.eu/export/sites/default/Documents/Projects/ESPON2006Projects/ScientificBriefingNetworking/UpdateOnAccessibilityMaps/espon_accessibility_update_2006_fr_070207.pdf.

Ustuga przeglądania (WMS) danych z budynkami BDOT, wersja: 1.3.0, [online] http://mapy.geoportal.gov.pl/wss/service/pub/guest/G2_BDOT_BUD_2010/MapServer/WMSServer. 
Ustuga przegladania (WMS) ortofotomap dla obszaru Polski, wersja: 1.3.0, [online] http://mapy. geoportal.gov.pl/wss/service/img/guest/ORTO/MapServer/WMSServer.

Ustawa z dnia 20 czerwca 1997 r. Prawo o ruchu drogowym, 1997, Dz.U., nr 98, poz. 602 z późn. $\mathrm{zm}$.

Ustawa z dnia 21 marca 1985 r. o drogach publicznych, 2012, Dz.U. poz. 260, 843 z późn. zm.

Ustawa z dnia 28 marca 2003 r. o transporcie kolejowym, 2003, Dz.U., nr 86, poz. 789.

Ustawa z dnia 16 grudnia 2010 r. o publicznym transporcie zbiorowym, 2011, Dz.U., nr 5, poz. 13.

Vickerman R.W., 1974, Accessibility, Attraction, and Potential: a Review of Some Concepts and Their Use in Determining Mobility, „Environment and Planning A”, no. 6, s. 675-691.

Warakomska K., 1992, Zagadnienie dostępności w geografii transportu, „Przegląd Geograficzny”, t. 64 (1-2), s. 67-76.

Wendt J., 2000, Dostępność komunikacyjna ośrodków władzy wojewódzkiej, „Prace Komisji Geografii Komunikacji PTG”, t. 6, s. 183-202.

Wersje skonsolidowane Traktatu o Unii Europejskiej i Traktatu o funkcjonowaniu Unii Europejskiej, 2012, „Dziennik Urzędowy Unii Europejskiej”, nr C 326 z 26 października.

Wiesiołowski J., 1980, Sieć miejska w Wielkopolsce w XIII-XVI w. Przestrzeń i Społeczeństwo, „Kwartalnik Historii Kultury Materialnej”, r. 28, z. 3.

Witryna dostępności transportowej IGiPZ PAN, [online], http://www.igipz.pan.pl/accessibility/pl/ home.html.

Witryna internetowa European Road Assessment Programme, [online] http://www.eurorap.pl/index. php?option $=$ com content\&view $=$ article \&id $=99$.

Witryna internetowa Generalnej Dyrekcji Dróg Krajowych i Autostrad, [online] www.gddkia.gov. pl.

Witryna internetowa Geospatial Modelling Environment, [online] http://www.spatialecology.com/ gme/.

Witryna internetowa http://www.danetechniczne.com.pl/.

Witryna internetowa Instytutu Badań Rynku Morotyzacyjnego SAMAR, [online] http://www.samar. $\mathrm{pl} /$.

Witryna internetowa Kolei Waskotorowych w Polsce, [online] http://www.koleje.wask.pl/.

Witryna internetowa Miejskiego Przedsiębiorstwa Komunikacyjnego w Lodzi, [online] http://www. mpk.lodz.pl/.

Witryna internetowa PKP Polskich Linii Kolejowych S.A., [online] http://www.plk-sa.pl/.

Witryna internetowa policji, [online] www.policja.pl.

Witryna internetowa Polskiej Izby Gospodarczej Transportu Samochodowego i Spedycji, [online] http://autobusowyrozkladjazdy.pl/.

Witryna internetowa projektu TEN-T: TENtec Public Portal, [online] http://ec.europa.eu/transport/ infrastructure/tentec/tentec-portal/site/en/tentec.html.

Witryna internetowa rozkładu jazdy pociagów PKP S.A., [online] http://www.rozklad- pkp.pl/bin/ query.exe/pn?.

Witryna internetowa Transportation Research Board of National Academies, [online] http://www. trb.org/Main/Blurbs/Highway_Capacity_Manual_2010_HCM2010_164718.aspx.

Wniosek COM/2011/650 Komisji z dnia 6 lutego 2012 r. Rozporzadzenie Parlamentu Europejskiego $i$ Rady w sprawie unijnych wytycznych dotyczacych rozwoju Transeuropejskiej Sieci Transportowej, nr procedury COD/2011/0294.

Wniosek COM/2012/665 Komisji z dnia 13 marca 2012 r. Rozporządzenie Parlamentu Europejskiego i Rady ustanawiajace instrument „, Łaczac Europe”, nr procedury COD/2011/0302.

Zagożdżon A., 1970, Metody grafowe w badaniach osadnictwa, „Przegląd Geograficzny”, t. 42 (2), s. 335-348. 
Zagożdżon A., 1971, Analiza układów przestrzennych osiedli rejonu uprzemystowionego z wykorzystaniem technik z zakresu teorii grafów, [w:] Rejony uprzemystowione. Problematyka i badania, KiZBRU PAN, Warszawa, s. 289-296.

Zagożdżon A., 1977, Wykorzystanie metod $i$ technik grafowych $w$ analizie struktur przestrzennych, [w:] Chojnicki Z. (red.), Metody ilościowe i modele $w$ geografii, PWN, Warszawa, s. $158-169$.

Załacznik 2.20 do decyzji Parlamentu Europejskiej i Rady nr 661/2010/UE z dnia 7 lipca 2010 r. w sprawie unijnych wytycznych dotyczacych rozwoju Transeuropejskiej Sieci Transportowej, 2010, „Dziennik Urzędowy Unii Europejskiej”, nr L 204 z 5 sierpnia.

Załacznik 2.1 do regulaminu przydzielania tras pociagów $i$ korzystania z przydzielonych tras pociagów przez licencjonowanych przewoźników kolejowych w ramach rj 2012/2013 (w. 0).

Załacznik 3.18 do decyzji Parlamentu Europejskiej i Rady Nr 661/2010/UE z dnia 7 lipca 2010 r. w sprawie unijnych wytycznych dotyczacych rozwoju Transeuropejskiej Sieci Transportowej, 2010, „Dziennik Urzędowy Unii Europejskiej”, nr L 204 z 5 sierpnia.

Zamieszkane budynki. Narodowy Spis Powszechny Ludności i Mieszkań 2011, 2013, Główny Urząd Statystyczny, Warszawa, [online] http://www.stat.gov.pl/cps/rde/xbcr/gus/L_zamieszk_budynki_nsp_2011.pdf.

Zasady prognozowania wskaźników wzrostu ruchu wewnętrznego na okres 2008-2040 na sieci drogowej do celów planistyczno-projektowych, [online] https://www.gddkia.gov.pl/userfiles/ articles/p/pismo-przewodnie-z-dnia-15032007_4423/Zalacznik_2_Zasady_prognozowania_ wskaznikow_wzrostu_2008-2040.pdf. 



\section{SPIS RYCIN}

Rycina 1.1. Elementy precyzujące dostępność transportową obszaru .................................. 22

Rycina 1.2. Główne zagadnienia ujmowane w metodach pomiaru dostępności transportowej... 25

Rycina 1.3. Struktura uwarunkowań dostępności transportowej ........................................... 34

Rycina 2.1. Sieć dróg krajowych (stan na 23.05.2014) ...................................................... 56

Rycina 2.2. Gęstość linii kolejowych w Polsce według województw w 2012 r.................... 57

Rycina 2.3. Gęstość dróg ekspresowych i autostrad w Polsce według województw w 2012 r... 58

Rycina 2.4. Gęstość dróg zamiejskich o twardej nawierzchni ulepszonej w Polsce według województw w 2012 r. ................................................................................. 59

Rycina 2.5. Liczba pojazdów w Polsce według województw w 2012 r............................... $\quad 60$

Rycina 2.6. Sieć osadnicza województwa łódzkiego w świetle zasady komunikacyjnej

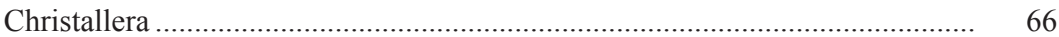

Rycina 2.7. Sieć dróg województwa łódzkiego (stan na 1.06.2014) ...................................... 67

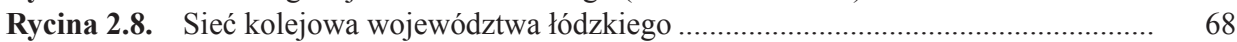

Rycina 2.9. Sieć tramwajowa w województwie łódzkim.................................................... 74

Rycina 2.10. Przestrzenne zróżnicowanie odległości topologicznych miast województwa łódzkiego w sieci drogowej....

Rycina 2.11. Zestawienie odległości topologicznych miast województwa łódzkiego w sieci drogowej i kolejowej

Rycina 2.12. Deformacja granicy województwa łódzkiego w wyniku przyjęcia odległości fizycznych rzeczywistych drogowych do Łodzi

Rycina 2.13. Deformacja granicy województwa łódzkiego w wyniku przyjęcia odległości fizycznych rzeczywistych kolejowych do Łodzi.

Rycina 2.14. Potencjał transportowo-osadniczy oraz liczba efektywnych połączeń w sieci drogowej do miast województwa łódzkiego .....

Rycina 2.15. Struktura potencjału transportowo-osadniczego miast województwa łódzkiego w sieci drogowej.....

Rycina 2.16. Potencjał transportowo-osadniczy oraz liczba efektywnych połączeń w sieci kolejowej do miast województwa łódzkiego

Rycina 2.17. Struktura potencjału transportowo-osadniczego miast województwa łódzkiego w sieci kolejowej

Rycina 2.18. Siła i kierunek oddziaływania relacji transportowo-osadniczych I, II i III rzędu (sieć drogowa)

Rycina 2.19. Siła i kierunek oddziaływania relacji transportowo-osadniczych I, II, III rzędu (sieć kolejowa)...

Rycina 2.20. Graf na tle sieci drogowej województwa łódzkiego ...................................... 93

Rycina 2.21. Graf na tle sieci kolejowej województwa łódzkiego........................................ 95

Rycina 2.22. Przestrzenne zróżnicowanie dostępności topologicznej miast województwa łódzkiego w sieci drogowej. 
Rycina 2.23. Przestrzenne zróżnicowanie dostępności topologicznej miast województwa łódzkiego w sieci kolejowej.

Rycina 2.24. Przestrzenne zróżnicowanie wartości $r$ na podstawie wskaźnika $S$ - $I$ miast województwa łódzkiego w sieci drogowej...

Rycina 2.25. Przestrzenne zróżnicowanie wartości $r$ na podstawie wskaźnika $S$ - $I$ miast województwa łódzkiego w sieci kolejowej...

Rycina 2.26. Przestrzenne zróżnicowanie dostępności topologicznej miast województwa łódzkiego w sieci drogowej w ujęciu międzyregionalnym

Rycina 2.27. Przestrzenne zróżnicowanie dostępności topologicznej miast województwa łódzkiego w sieci kolejowej w ujęciu międzyregionalnym

Rycina 2.28. Kolejowe wyposażenie infrastrukturalne buforów wokół miast województwa łódzkiego

Rycina 2.29. Kolejowe i tramwajowe wyposażenie infrastrukturalne buforów wokół miast województwa łódzkiego.

Rycina 3.1. Bezpośrednie połączenia autobusowe/busowe do miast województwa łódzkiego w podziale na zwykłe oraz przyspieszone i pośpieszne.

Rycina 3.2. Połączenia kolejowe do miast województwa łódzkiego w podziale na bezpośrednie oraz z przesiadką.

Rycina 3.3. Częstotliwość połączeń kolejowych pomiędzy miastami województwa łódzkiego

Rycina 3.4. Długość połączeń kolejowych pomiędzy miastami województwa łódzkiego ...

Rycina 3.5. Czas połączeń kolejowych pomiędzy miastami województwa łódzkiego..........

Rycina 3.6. Ceny połączeń kolejowych pomiędzy miastami województwa łódzkiego .........

Rycina 3.7. Częstotliwość (a), czas (b), cena (c) i długość (d) połączeń tramwajowych pomiędzy miastami województwa łódzkiego

Rycina 3.8. Potencjał oraz siła i kierunek ciążenia komunikacyjnego (I, II i III rzędu) miast województwa łódzkiego w świetle komunikacji autobusowej i busowej (opór przestrzeni w jednostkach długości)

Rycina 3.9. Potencjał oraz siła i kierunek ciążenia komunikacyjnego (I, II i III rzędu) miast województwa łódzkiego w świetle komunikacji kolejowej (opór przestrzeni w jednostkach długości)

Rycina 3.10. Potencjał oraz siła i kierunek ciążenia komunikacyjnego (I, II i III rzędu) miast województwa łódzkiego w świetle komunikacji kolejowej (opór przestrzeni w jednostkach czasu)

Rycina 3.11. Potencjał oraz siła i kierunek ciążenia komunikacyjnego (I, II i III rzędu) miast województwa łódzkiego w świetle komunikacji kolejowej (opór przestrzeni w jednostkach pieniężnych)

Rycina 3.12. Położenie przystanków poddanych analizie.

Rycina 3.13. Liczba przystanków PKS, LTZ, BUS oraz PKP w izochronie jednogodzinnej wokół miast województwa łódzkiego

Rycina 3.14. Rodzaj przewoźnika oraz czas dojazdu do Łodzi w zakresie izochrony jednogodzinnej

Rycina 3.15. Rodzaj przewoźnika oraz czas dojazdu do Piotrkowa Trybunalskiego w zakresie izochrony jednogodzinnej..

Rycina 3.16. Rodzaj przewoźnika oraz czas dojazdu do Piotrkowa Trybunalskiego w zakresie izochrony jednogodzinnej.

Rycina 3.17. Częstotliwość oraz koszt dojazdu do Sulejowa w zakresie izochrony jednogodzinnej 
Rycina 4.1. Liczba ośrodków w izochronach dojazdu samochodem osobowym do miast województwa łódzkiego

Rycina 4.2. Czas dojazdu do Wieruszowa przy założeniu poruszenia się samochodem osobowym z maksymalną dozwoloną prędkością

Rycina 4.3. Czas dojazdu do Łodzi przy założeniu poruszenia się samochodem osobowym z maksymalną dozwoloną prędkością

Rycina 4.4. Liczba ośrodków $w$ izodapanach dojazdu samochodem osobowym do miast województwa łódzkiego

Rycina 4.5. Koszt dojazdu do Wieruszowa przy założeniu poruszenia się samochodem osobowym z maksymalną dozwoloną prędkościa

Rycina 4.6. Koszt dojazdu do Łodzi przy założeniu poruszenia się samochodem osobowym z maksymalną dozwoloną prędkością

Rycina 4.7. Prędkości i koszty przejazdów na drogach krajowych i wojewódzkich w województwie łódzkim, zgodnie $\mathrm{z}$ modelem

Rycina 4.8. Czasy przejazdów po drogach krajowych i wojewódzkich w województwie łódzkim, zgodnie $\mathrm{z}$ modelem

Rycina 5.1. Klasyfikacja miast województwa łódzkiego pod względem potencjalnej dostępności transportowej....

Rycina 5.2. Klasyfikacja miast województwa łódzkiego pod względem dostępności w świetle transportu zbiorowego

Rycina 5.3. Klasyfikacja miast województwa łódzkiego pod względem dostępności w świetle transportu indywidualnego

Rycina 5.4. Zróżnicowanie przestrzenne dostępności transportowej miast województwa łódzkiego względem ich wielkości i oddalenia od Łodzi

Rycina 5.5. Typologia miast województwa łódzkiego pod względem dostępności transportowej 


\section{SPIS TABEL}

Tabela 2.1. Odległości topologiczne do miast województwa łódzkiego................................ 70

Tabela 2.2. Zmienne określające atrakcyjność miast ......................................................... 83

Tabela 2.3. Wskaźnik średnioważony wyposażenia infrastrukturalnego dla sieci drogowej w buforach wokół miast województwa łódzkiego............................................... 110

Tabela 2.4. Wyposażenie infrastrukturalne w miastach województwa łódzkiego .................. 113

Tabela 4.1. Parametry modelu - współczynnik wpływu zaludnienia ................................... 181

Tabela 4.2. Parametry modelu - współczynnik wpływu ukształtowania powierzchni terenu 183

Tabela 4.3. Parametry modelu - współczynnik wpływu natężenia ruchu.............................. 184

Tabela 5.1. Miasta województwa łódzkiego pod względem potencjalnej dostępności dro-

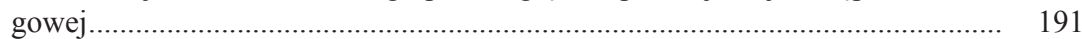

Tabela 5.2. Miasta województwa łódzkiego pod względem potencjalnej dostępności kolejowej.....

Tabela 5.3. Miasta województwa łódzkiego pod względem potencjalnej dostępności tramwajowej......

Tabela 5.4. Miasta województwa łódzkiego pod względem samochodowego transportu zbiorowego

Tabela 5.5. Miasta województwa łódzkiego pod względem kolejowego transportu zbiorowego.

Tabela 5.6. Miasta województwa łódzkiego pod względem czasu dojazdu transportem indywidualnym

Tabela 5.7. Miasta województwa łódzkiego pod względem kosztu dojazdu transportem indywidualnym 